\title{
The island rule and its application to multiple plant traits
}

\author{
Annemieke Lona Hedi Hendriks
}

A thesis submitted to the Victoria University of Wellington in partial fulfilment of the requirements for the degree of

\section{Master of Science}

in Ecology and Biodiversity

Victoria University of Wellington, New Zealand 2019

\section{VICTORIA \\ UNIVERSITY OF WELLINGTON \\ TE WHARE WĀNANGA \\ O TE ŪPOKO O TE IKA A MĀUI}

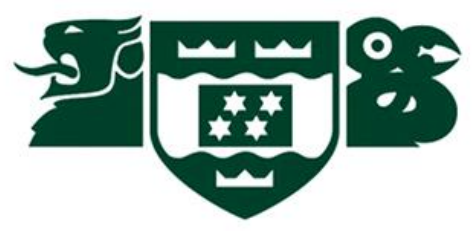




\section{"The larger the island of knowledge, the longer the shoreline of wonder"}

Ralph W. Sockman. 


\section{General Abstract}

Aim The Island Rule refers to a continuum of body size changes where large mainland species evolve to become smaller and small species evolve to become larger on islands. Previous work focuses almost solely on animals, with virtually no previous tests of its predictions on plants. I tested for (1) reduced floral size diversity on islands, a logical corollary of the island rule and (2) evidence of the Island Rule in plant stature, leaf size and petiole length.

Location Small islands surrounding New Zealand; Antipodes, Auckland, Bounty, Campbell, Chatham, Kermadec, Lord Howe, Macquarie, Norfolk, Snares, Stewart and the Three Kings.

Methods I compared the morphology of 65 island endemics and their closest 'mainland' relative. Species pairs were identified. Differences between archipelagos located at various latitudes were also assessed.

Results Floral sizes were reduced on islands relative to the 'mainland', consistent with predictions of the Island Rule. Plant stature, leaf size and petiole length conformed to the Island Rule, with smaller plants increasing in size, and larger plants decreasing in size.

Main conclusions Results indicate that the conceptual umbrella of the Island Rule can be expanded to plants, accelerating understanding of how plant traits evolve on isolated islands.

\section{Key words}

Island Rule, Island Biogeography, Plant Evolutionary Ecology, Phytogeography 


\section{Acknowledgements}

Initially I need to thank my supervisor Kevin Burns. I appreciate the time and enthusiasm he has had for the subject, and the patience and guidance he has shown me. I would also like to extend my thanks to members of the Burns lab, big ups for the discussions, foods and talks.

I am also thankful to those who have made day to day Masters life so much more enjoyable: Amber Brooks, Cherie Balls, Tyler Ritchie and Tom Dawes in particular have put up with my peculiar ideas, thesis solidification, fuzzy scientific ramblings, and rants. You all somehow always made a rainy day seem worthwhile. In addition, Tom also helped significantly with his proofreading services, a point I sincerely appreciate. A noted extra acknowledgement to Cherie for providing me with Sonchus grandifolius data, and being the person who had to listen to my tangents the most, too bad you ended up with a desk next to me! Also a special thanks to Dr. Michael Jackson for offering statistical guidance, employment and general all round enjoyment!

Big ups to my fellow demonstrators, lab tutors and also the students on all the courses I have been lucky enough to tutor. At some point, we will have discussed our respective projects, and many times, I went away with thoughts, which would improve my study. In a similar vein I want to extend my appreciation to fellow volunteers on Mana and Matiu/Somes Islands. The constant explanation of my degree truly helped me to nut out and refine my project.

A warm thank-you to Mary Murray and the administrative staff, you never fail to look out for us students if we come with a complaint, compliment or seeking guidance and equipment!

This thesis would not have been possible without the help of people from three additional institutions; namely:

Brian Rance from the Department of Conservation, thank-you for the list of endemic species occurring on the sub-Antarctic islands, this information was invaluable.

Ewen Cameron, Dhahara Ranatunga and the team from the Auckland War Museum Herbarium, I appreciate having been able to look over and measure specimens at short notice. Thank-you also for taking the time to respond to my queries.

To Carlos Lehnebach, Bridget Hatton and the team at Te Papa Herbarium, I am also indebted to you for welcoming me so warmly and allowing me to measure herbaria specimens over multiple days. 
To my dear house companions; Harrison Jones and Jaz Hamilton, it's so great when the people you live with are easy to get along with, and offer no end of support! Thanks for the proof reading, feedback, and opening the front door when I knock, even though I have a key. In addition, Jaz, you have encouraged me to tackle life with a unique perspective, and it's certainly been a fun adventure thus far. Cheers for cooking me dinners, proofreading, not grumbling too much when I would come home late, and for helping out with that sweet GIS map you made. You're pretty okay.

To Jemma McGiven, you deserve a special shout out. You always have my back no matter where we are in the world. Thank-you for taking the time to have conversations on a plethora of topics and corresponding through 'old fashioned' letters. Your encouragement and your friendship are very dear to me. I very much look forward to the adventures we will get up to in the future.

To Olivia Hendriks, if it weren't for all the random photos of the cat Cayla, or our dopy dog Shine, I most certainly would have gone mad and been terribly homesick. In return I hope you continue to appreciate that I am reliably the \#bestsisterever when I have been your personal duty-free collector when returning from Lord Howe.

To my Wellington based sisters Rachel Huddleston, Trina Seath and their families, I should like to say that family dinners have been something I always look forward to on the calendar. Nothing beats a delicious meal and good company.

To Oma (Lona Young), thank you for all your love and emails. They never cease to put a grin on my face, or joy in my heart. Thank you also for never giving up on Easter eggs, because that is a motivation that I specifically look forward to. I hope that I will continue to do you proud.

Finally, to my parents, Verena and John Hendriks. Words cannot express how grateful I am for your continued support and encouragement. It was no doubt difficult to accept my moving out, but I'm sure that the house is a lot calmer without my voice shouting through the hallway. I hope that you will be able to read my thesis and it will all seem rather worthwhile. Perhaps now it will all make sense, and I can stop explaining exactly what it is I actually did.

For anyone else that I have missed, and for those reading this from beyond the pearly gates, cheers. Just because you're not individually mentioned doesn't mean that I do not appreciate the support or insight you have shared with me on my journey, and I hope I have honoured you through the quality of my work. 


\section{Table of Contents}

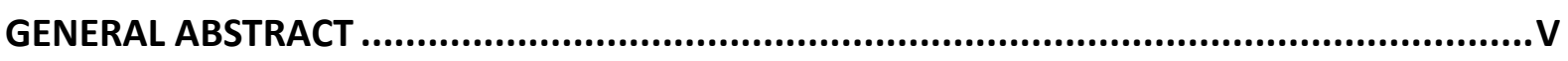

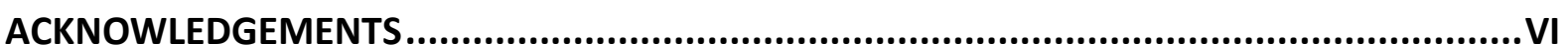

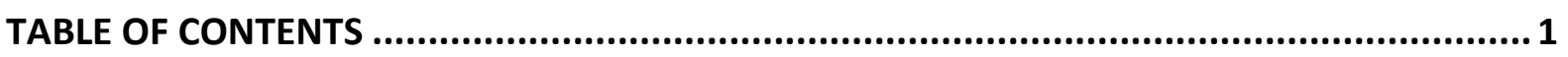

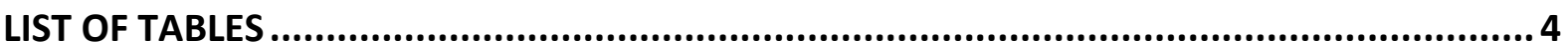

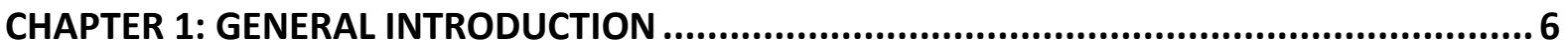

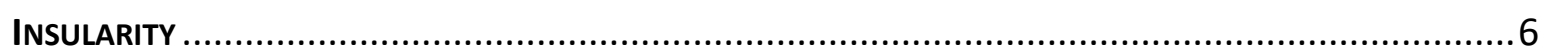

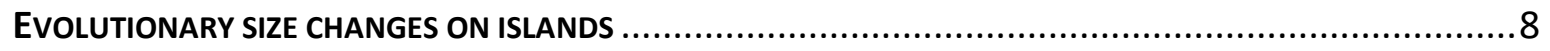

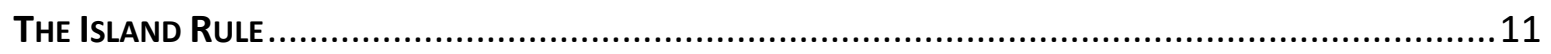

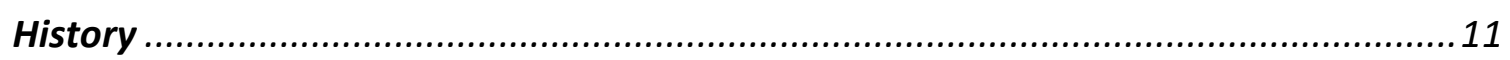

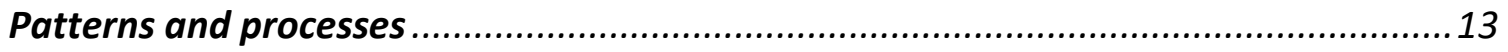

Evidence of Insular Dwarfism - Why might species get smaller? ..................................... 13

Evidence of Insular Gigantism - Why might species get bigger? ........................................ 15

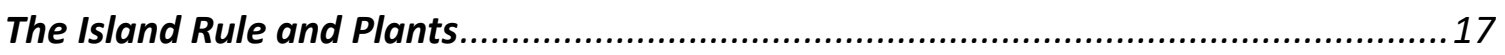

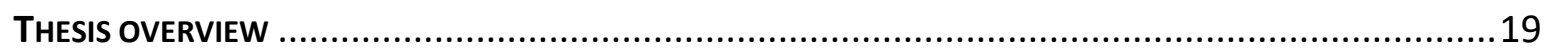

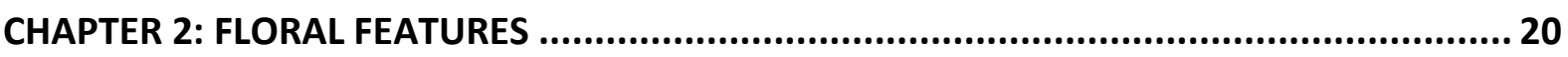

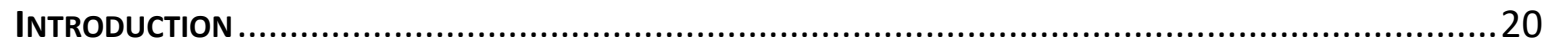

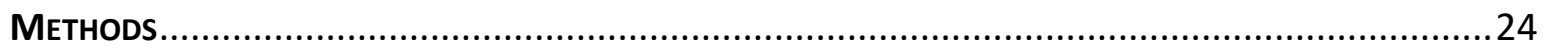

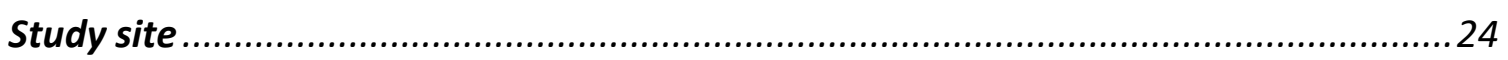

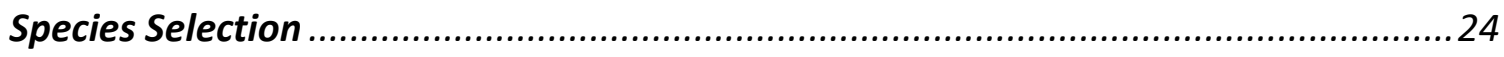

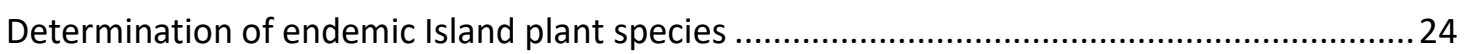

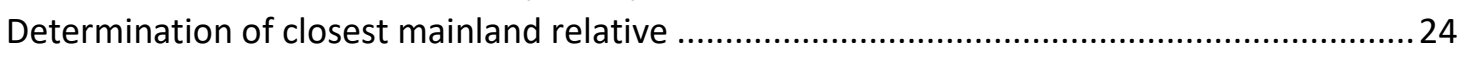

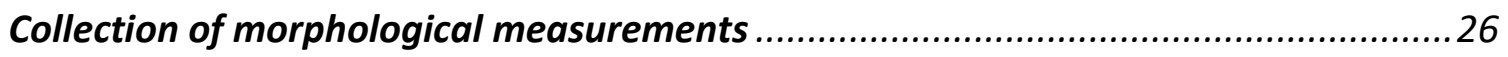

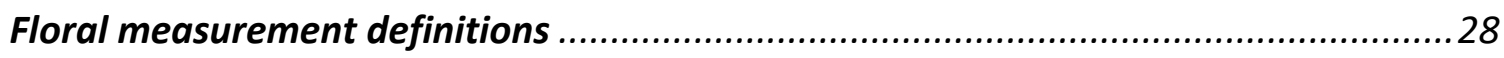

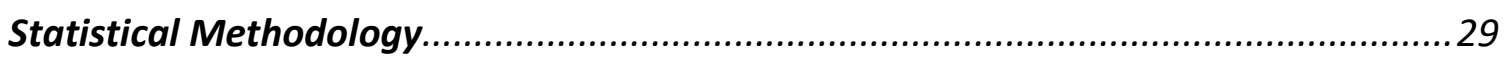

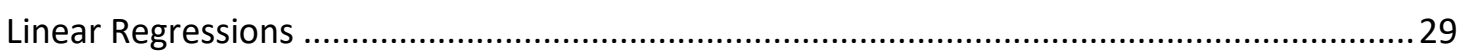

Testing of additional biological, climatic or geographical factors ............................................. 30

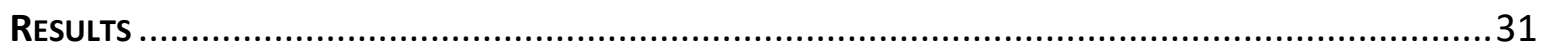

Analysis of Island Rule trend in floral features ............................................................. 31

Analysis of Island Rule trend in plants across additional biological, climatic or

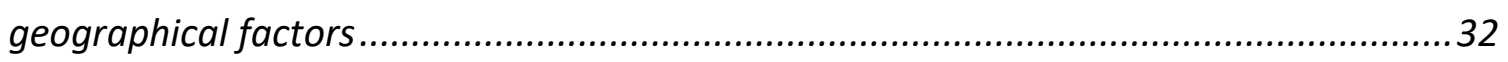

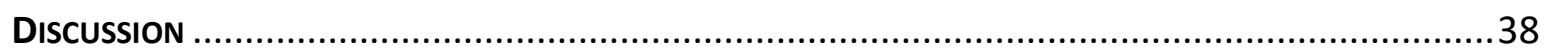

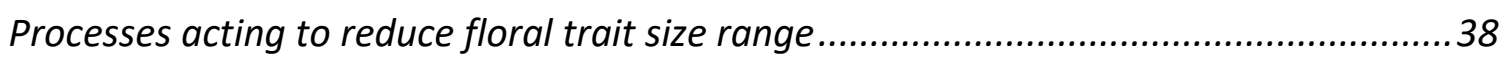

Possibly confounding effects of trait allometry............................................................ 39

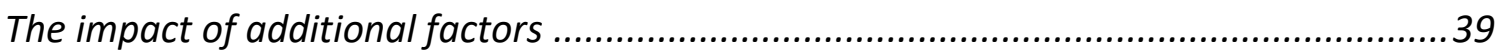

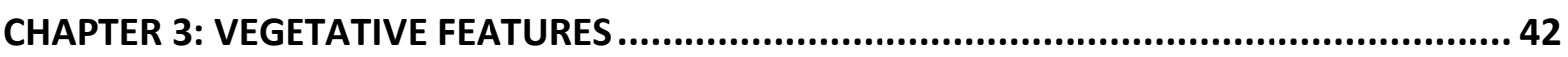

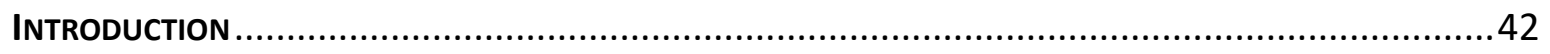

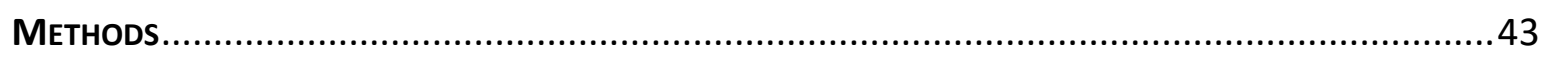

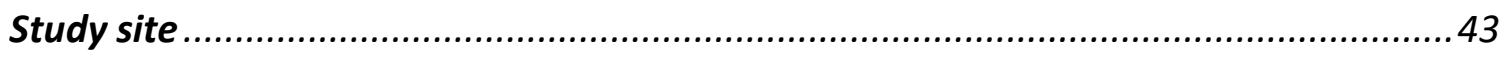




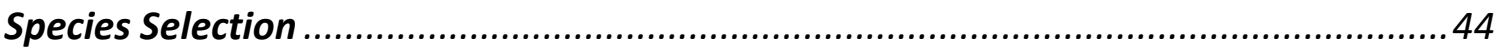

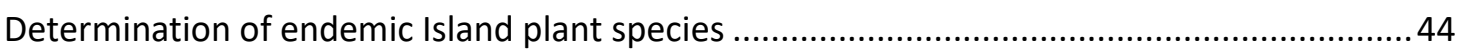

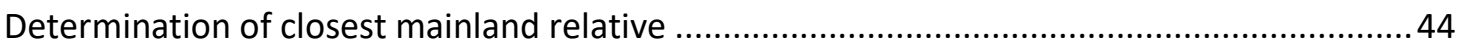

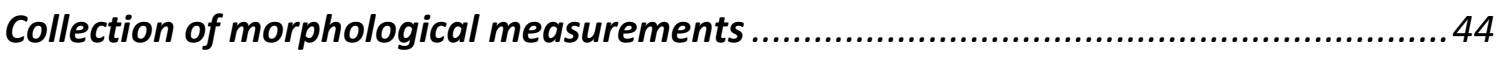

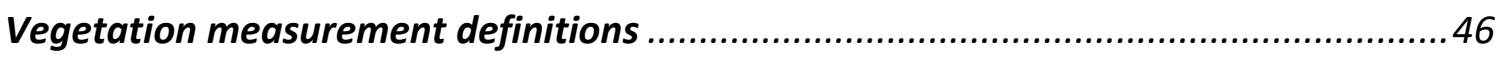

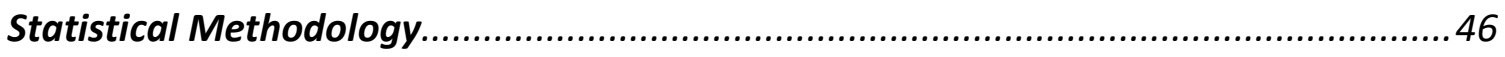

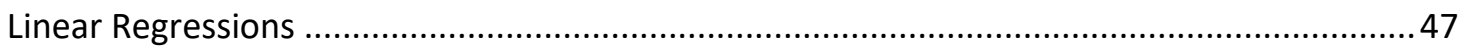

Testing of additional biological, climatic and geographical factors..............................47

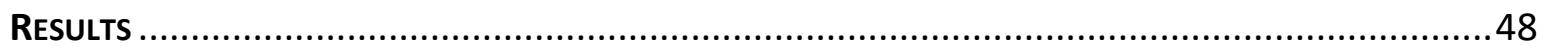

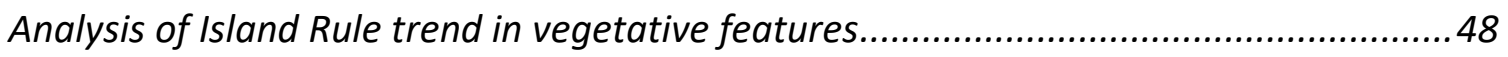

Analysis of Island Rule trend in plants across latitudes............................................... 48

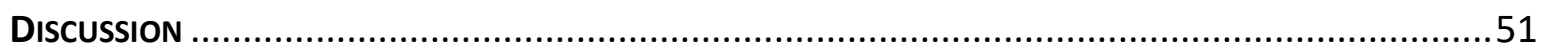

Processes acting to reduce vegetative trait size range ................................................51

Possibly confounding effects of trait allometry........................................................... 52

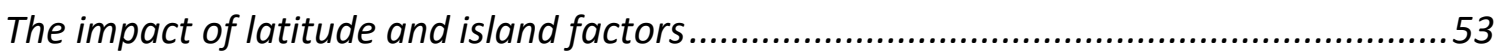

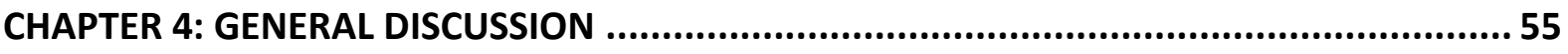

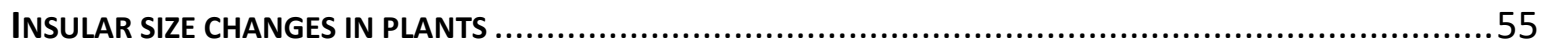

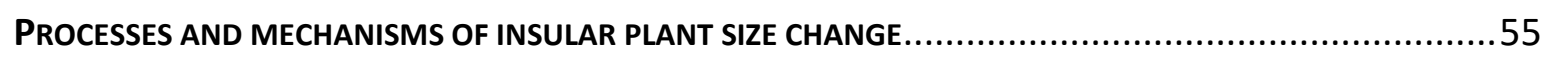

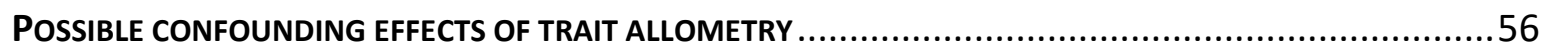

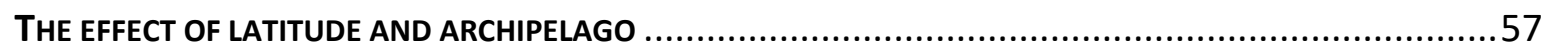

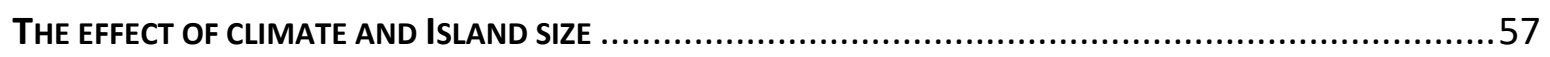

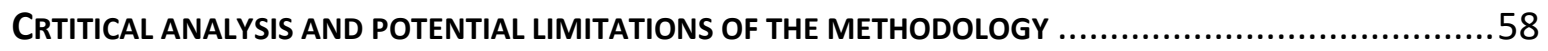

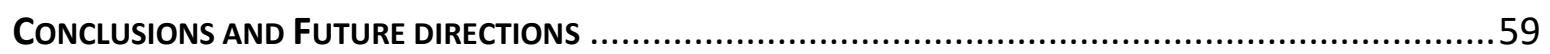

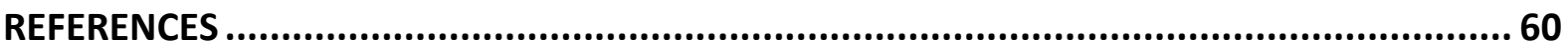

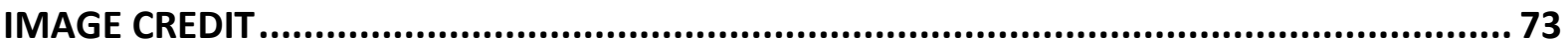

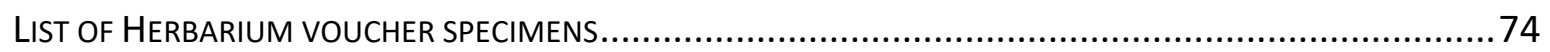

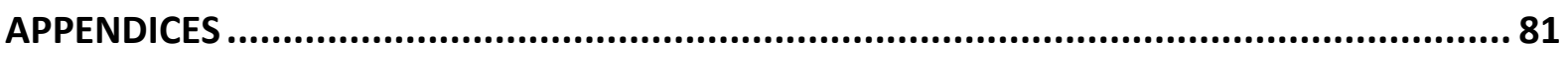

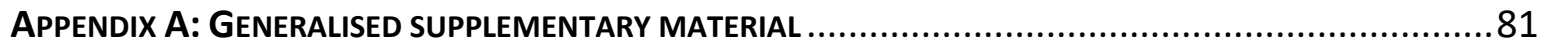

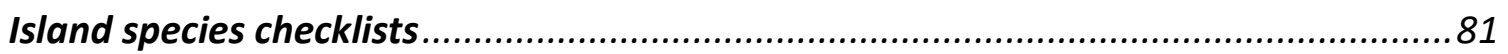

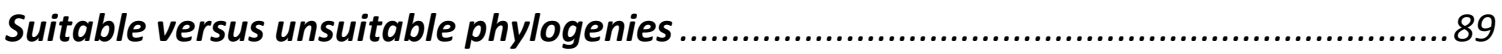

Taxomic order breakdown per island of all endemic species......................................90

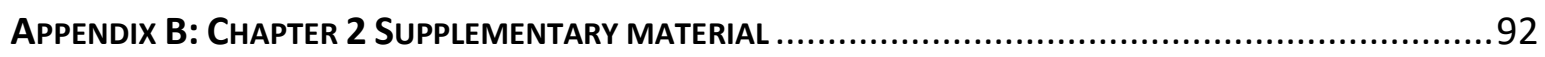

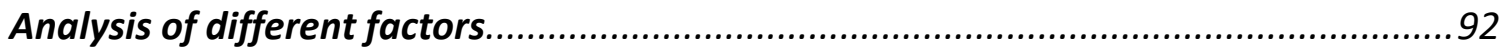

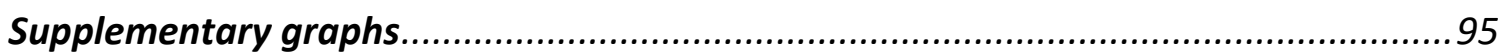

Species composition and measurement type and reference for floral features .......... 96

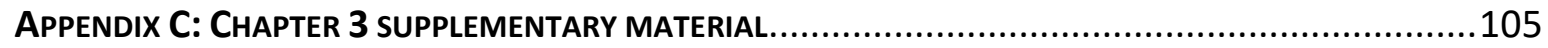

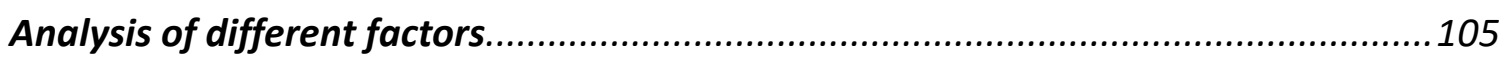

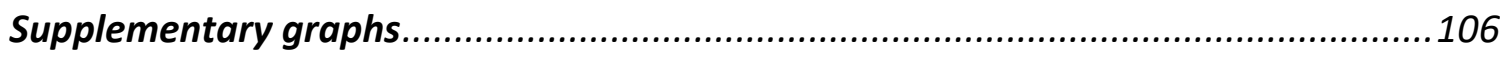

Species composition and measurement type and reference for vegetative features. 108 


\section{List of Figures}

\section{CHAPTER 1}

Figure 1.1: Island Endemic Probability in relation to Island size and location..............................7

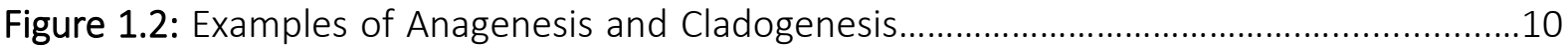

Figure 1.3: Three evolutionary scenarios for size changes.......................................................10

Figure 1.4: An illustration of the Island Rule displayed in two ways.........................................12

\section{CHAPTER 2}

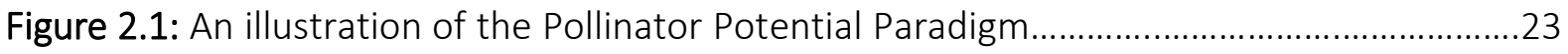

Figure 2.2: Map of islands around New Zealand included in this study....................................25

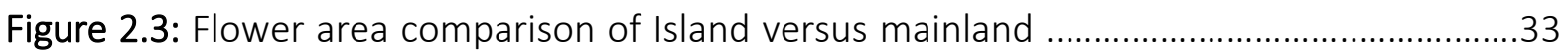

Figure 2.4: Inflorescence length comparison of Island versus mainland......................................34

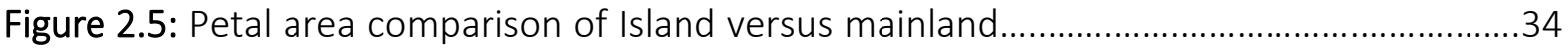

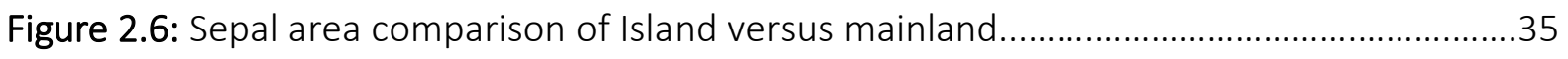

Figure 2.7: Filament length comparison of Island versus mainland...........................................35

Figure 2.8: Anther length comparison of Island versus mainland.............................................36

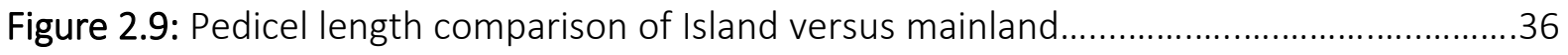

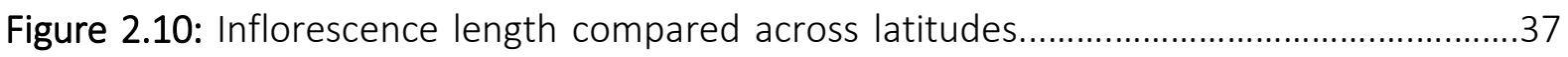

Figure 2.11: Significant graphic results of certain floral features across different factors........37

\section{CHAPTER 3}

Figure 3.1: Plant stature comparison of Island versus mainland .........................................49

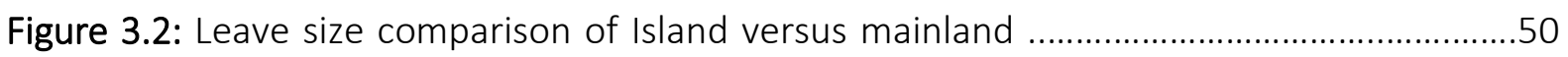

Figure 3.3: Petiole length comparison of Island versus mainland ...........................................50

Figure 3.4: Significant graphic results of Stature across different factors ...................................51

\section{APPENDIX A}

Figure A1: Suitable versus unsuitable phylogenies .89

\section{APPENDIX B}

Figure B1: Non-significant graphic results of latitude for floral features. .95

\section{APPENDIX C}

Figure C1: Plant stature comparison of Island versus mainland (including outlier)..................106

Figure C2: Graphic results of Island Rule across latitude for stature (with outlier)...................107

Figure C3: Cook's distance graph of stature displaying the outlier...........................................107

Figure C4: Graphic results of Island Rule across latitude for vegetative features.......................107 


\section{List of tables}

\section{CHAPTER 2}

Table 2.1: The breakdown of species representation from identified islands of interest.........26

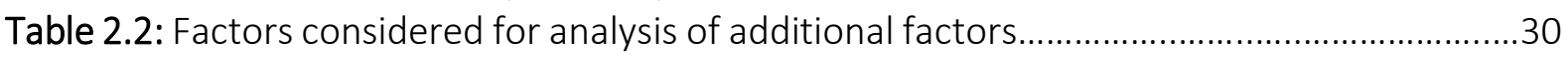

Table 2.3: Latitude values for islands with insular species in the study.....................................31

Table 2.4: Floral features and their statistical significance in light of the Island Rule..................31

\section{CHAPTER 3}

Table 3.1: Vegetative features and their statistical significance in light of the Island Rule. 49

\section{REFERENCES}

Table R1: List of voucher specimens and their location. .74

\section{APPENDIX A}

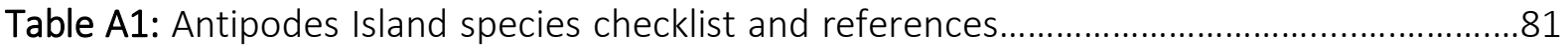

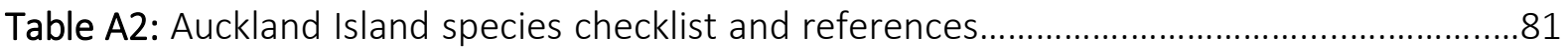

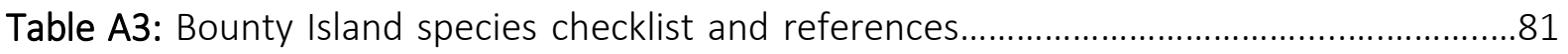

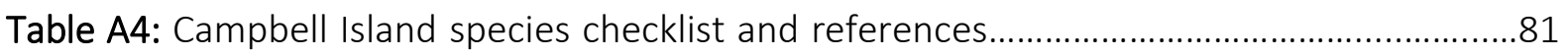

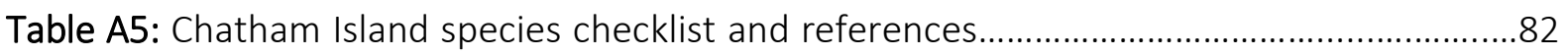

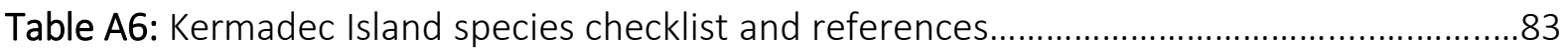

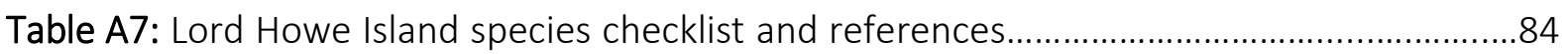

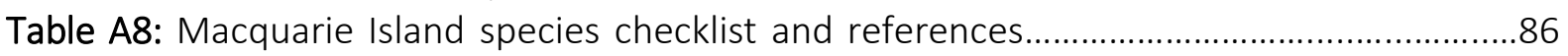

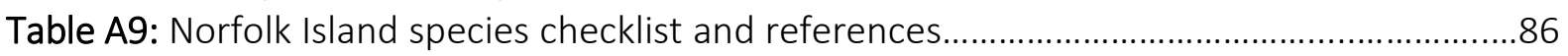

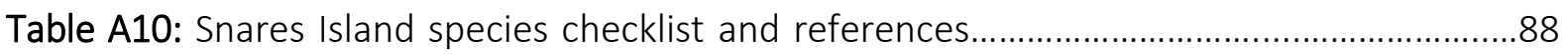

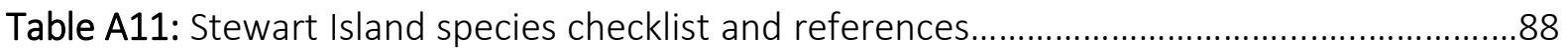

Table A12: Three Kings Island species checklist and references.............................................8

Table A13: Endemic species frequency group by taxonomic order and island..........................90

Table A14: Island Group Frequency per morphological feature ...............................................91

\section{APPENDIX B}

Table B1: Analysis of Island Rule in floral features across latitude .........................................92

Table B2: Filament length statistical values for different factors ............................................92

Table B3: Petal area statistical values for different factors .....................................................93

Table B4: Sepal area statistical values for different factors ..................................................93

Table B5: Anther length statistical values for different factors ...............................................93

Table B6: Inflorescence length statistical values for different factors ..................................94

Table B7: Flower area statistical values for different factors ....................................................94

Table B8: Pedicel length statistical values for different factors ...................................................94

Table B9: Flower area dataset measurements and measurement reference .............................96

Table B10: Inflorescence length dataset measurements and measurement reference ............97

Table B11: Petal area dataset measurements and measurement reference .............................98

Table B12: Sepal area dataset measurements and measurement reference ...........................100 
Table B13: Filament length dataset measurements and measurement reference 101

Table B14: Anther length dataset measurements and measurement reference

Table B15: Pedicel length dataset measurements and measurement reference

\section{APPENDIX C}

Table C1: Analysis of Island Rule in vegetative features across latitude 105

Table C2: Statistical Results of Island Rule across latitude for stature (with outlier)................105

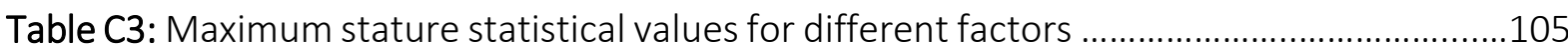

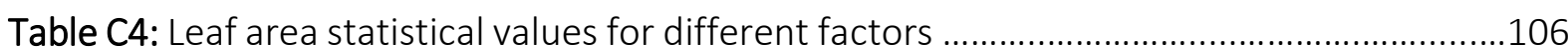

Table C5: Petiole length statistical values for different factors models ....................................106

Table C6: Maximum stature dataset measurements and measurement reference .................108

Table C7: Leaf area dataset measurements and measurement reference ...............................110

Table C8: Petiole length dataset measurements and measurement reference .......................112 


\section{Chapter 1: General Introduction}

\section{Insularity}

Insularity in a biogeographical sense can be defined by a location's isolation. Islands are a frequently used as examples of isolation, and can be defined in two ways; either 'habitat islands' (where discrete habitat patches are surrounded by a contrasting environment) or 'true islands' (the classical interpretation of an island where land is surrounded by sea) (Whittaker \& Fernández-Palacios, 2007). True islands are either oceanic or continental. Oceanic Islands are landmasses that have formed at oceanic plate boundaries totally isolated from continental landmasses. Continental islands have been in contact with a continent at some point in the past. Connection with the continent may have occurred via 'land-bridges' when global sea levels were lower, and later isolation may have taken place via tectonic processes such as continental drift, or rising sea levels.

Rather than a categorical term, insularity is dependent on the perspective, meaning a landmass can be both an 'island' and a 'mainland'. For example, individuals from Australia can disperse across the Tasman Sea and colonise New Zealand. In this instance, Australia can be considered the mainland and New Zealand could be considered the island. However, the satellite islands surrounding New Zealand could be populated by the North or South Island, and in this case New Zealand then acts as the mainland, and the satellite island acts as the island. In short, the location of the 'source' population location acts a mainland, and 'sink' population location is an island.

Island insularity and size may result in different levels of size changes and endemism. In relation to bigger areas, small areas house less species richness, with less diversity intraspecifically as well (Whitehead \& Jones, 1969). Small islands may also have less habitat heterogeneity, making them harder to establish on (Whitehead \& Jones, 1969). Competition between similar species is low, as the statistical likelihood that multiple species with a similar niche disperse to, inhabit and successfully persist on the same island is low. Dispersal probability and extreme interspecific competition reduces with island size. Small islands also have a reduced potential for available resources, leading to an increase in unique endemic adaptations (Falkland \& Custodio, 1991; Whittaker et al., 2014; see Figure 1.1 relating to this concept). Current extant distribution patterns of plants do not necessarily display past patterns 
of dispersal but, for the purposes of this thesis it is an assumption that is held. Alternative mechanisms such as local extinctions could lead to the current distribution as well. The most parsimonious explanation for this is that lineages split from a progenitor in their respective areas where the lineage is maintained. It is less likely for a lineage to arise, disperse to a new locality, and for the progenitor to also become extinct or alter.

For this thesis, only islands within $1800 \mathrm{~km}$ of the coast of New Zealand were included. These islands were identified as having species that most likely originated from New Zealand. The majority of these islands formed under oceanic processes. New Zealand and its islands isolated from Gondwana about 80 million years ago. Lord Howe, Norfolk and Macquarie islands are 7 million, 2.5 million and 300,000 years old respectively, having arisen through undersea volcanic activity (Diamond, 1984; Waters \& Craw, 2006). Terrestrial taxa arriving to islands all had to disperse overwater. However, land bridges may have connected some of the smaller islands around New Zealand and aided in species dispersal abilities (Diamond, 1984; Waters \& Craw, 2006). The islands that were considered for this study are: Antipodes, Auckland, Bounty, Campbell, Chatham, Kermadec, Lord Howe, Macquarie, Norfolk, Snares, Stewart and the Three Kings (Figure 2.2).

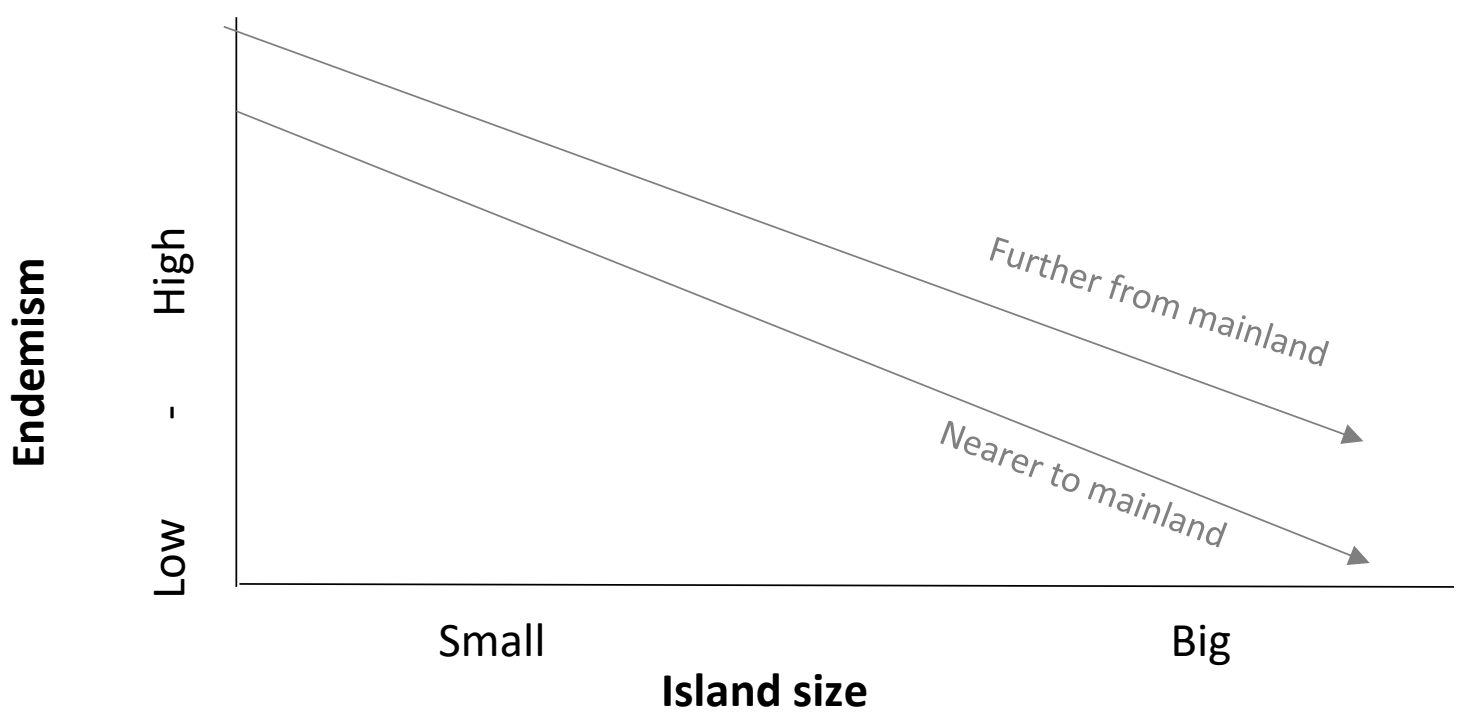

Figure 1.1 Probability for an endemic species persisting in relation to island size and relative location (in the absence of stochastic processes or abrupt climatic oscillations). Available resources and unused niche space generally decreases with Island size, making probability high on small islands. Inter-specific competition and niche competition increases while potential for genetic drift decreases with proximity to "mainland", making persistence and survival probability lower on bigger islands. 


\section{Evolutionary size changes on islands}

Size changes and species divergence occurs on islands via means of cladogenesis or anagenesis (see Figure 1.2). Species radiations (a form of cladogenesis) are popular study subjects, resulting in a bias of studies focused on cladogenesis, rather than anagenesis (Schluter, 2000; Stuessy et al., 2006). Anagenesis is on average less prevalent as a model of evolution compared to cladogenesis, a fact which may explain the limited reporting on the subject (Stuessy et al., 2006). In addition, Stuessy et al. (2006) states that anagenesis frequency seems to strongly depend on the island system. A classic example of radiation and cladogenesis is that of "Darwin's finches" where multiple beak structures of Galapagos Island finches must have arisen from a single mainland ancestor (Grant \& Grant, 2002). For plants as well, cladogenesis has been widely reported on, for example: Lord Howe has radiations of both palms, and Coprosma species, and Madagascar has Canarium (Savolainen et al., 2006; Federman, et al. 2015). While there is significant study surrounding instances of cladogenesis, studies dealing with anagenesis are generally less frequent (Schluter, 2000; Stuessy et al., 2006 ). However, since 2006, examples of plant anagenesis have become increasingly researched (Takayama, Sun \& Stuessy, 2013).

Cladogenesis examples are the product of two or more sister taxa. In a clade formed by two sister taxa, one species may come from a geographic location larger, than the other species. According to the island section earlier, species from larger areas represent the mainland population, while the other species must therefore represent the island taxa. It is assumed that very little or no morphological change has occurred on the mainland, and that change is restricted to islands due to practical thesis limitations. For phylogenetic comparison of sister taxa, the 'mainland' species was a realistic proxy of the progenitor species.

Genetic changes between sister taxa due to speciation lead to three possible evolutionary size change scenarios. The divergent population may display larger traits, secondly that the divergent group may display smaller traits and thirdly that there is no distinct size change in the divergent group (see Figure 1.3). Changes to morphology are not necessarily uniform within or between sister taxa, meaning that while one insular trait may show evolutionary size change, such change may occur independently of other traits (Chapin III, Autumn \& Pugnaire, 1993). If adaptive, size changes in different insular plant traits could be 
the result of multiple island selection pressures acting independently of one another (Burns, Herold \& Wallace, 2012; Kavanagh \& Burns, 2014; Burns, 2016a).

Size range of a species will be somewhat dictated by the colonising individual or group. The first mainland ancestor population to establish on the island will already display traits for a certain size. Dispersal-related filters (such as biological dispersal via animals) likely explain the bias of certain plant lineages on islands (Burns, 2005). Although the island species is expected to change morphology over evolutionary timescale, the mainland progenitor species is not expected to undergo significant morphological change due to unaltered selection pressures (Lomolino, 2005). It would be unexpected that large species become smaller, and vice versa, (without a significant time period).

However, plants may display similar traits between 'species pairs', as insular species may favour particular evolutionary pathways, resulting in repeated forms of evolution. For example, a particularly exposed and sunny island (relative to the mainland) may have many endemic plant species with small leaves. In this setting, small leaves may be evolutionarily advantageous in comparison to large leaves, as they are better suited to cope with temperature regulation, and sunlight over-exposure. In this sense environmental factors (and biological factors), almost certainly provide basis for size changes in particular morphological features. Such factors and selection pressures consistently occur in island settings, making island settings perfect experiments isolated by space and time.

Comparisons of Island and mainland plant traits offer insight into these 'island laboratories'. This thesis deals with ten specific morphological features over two trait groupings. These trait groups were selected because 1.) seeds and replicative features have been considered already, 2.) to offer further quantitative support for tests involving vegetative features, and 3.) as a novel consideration, as to my knowledge, specific investigation of floral features in this context has not occurred before.

The first group is Floral features. This group was comprised of features specifically relating to flowers. Flower area (overall flower length $x$ overall flower width), Inflorescence length, petal area (petal length $x$ petal width), sepal area (sepal length $x$ sepal width), filament length, anther length, and pedicel length. The second group was comprised of Vegetative features. Vegetative features included stature (total height of a plant), leaf area (lamina length 
x lamina width), and petiole length. More specific details related to how these measurements were defined and measured are in their respective chapters. Reproductive features (such as seeds and fruits) were excluded from this thesis, as there are already adequate investigation in this area (Kavanagh \& Burns, 2014), and there is limited opportunity to significantly improve the current sampling size.

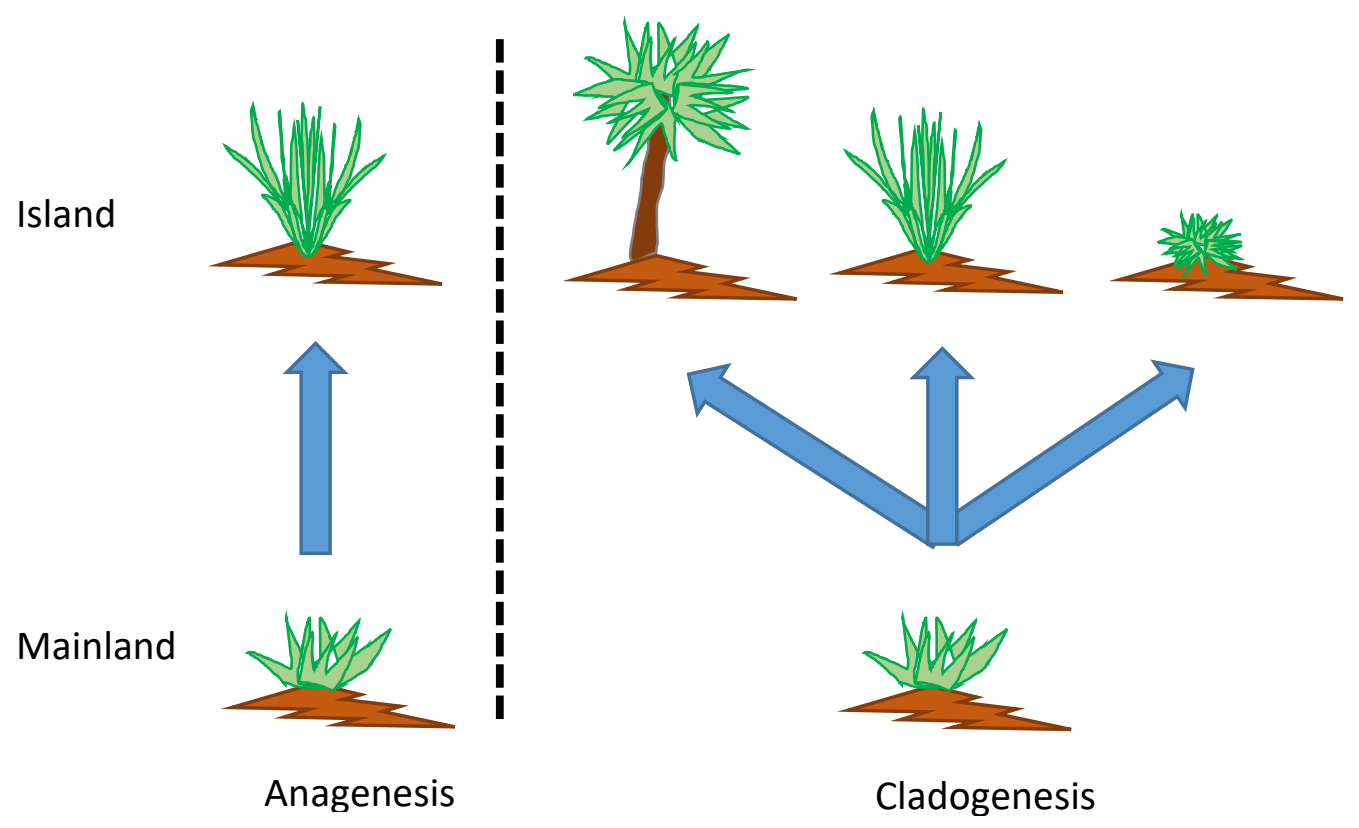

Figure 1.2 Anagenesis occurs when new species form along a lineage without any branching in the line of descent. Cladogenesis occurs when a new clade (or group) of species arise by evolutionary divergence from an ancestral form. This thesis assumes that the mainland form is extant and that has undergone little or no evolutionary change.

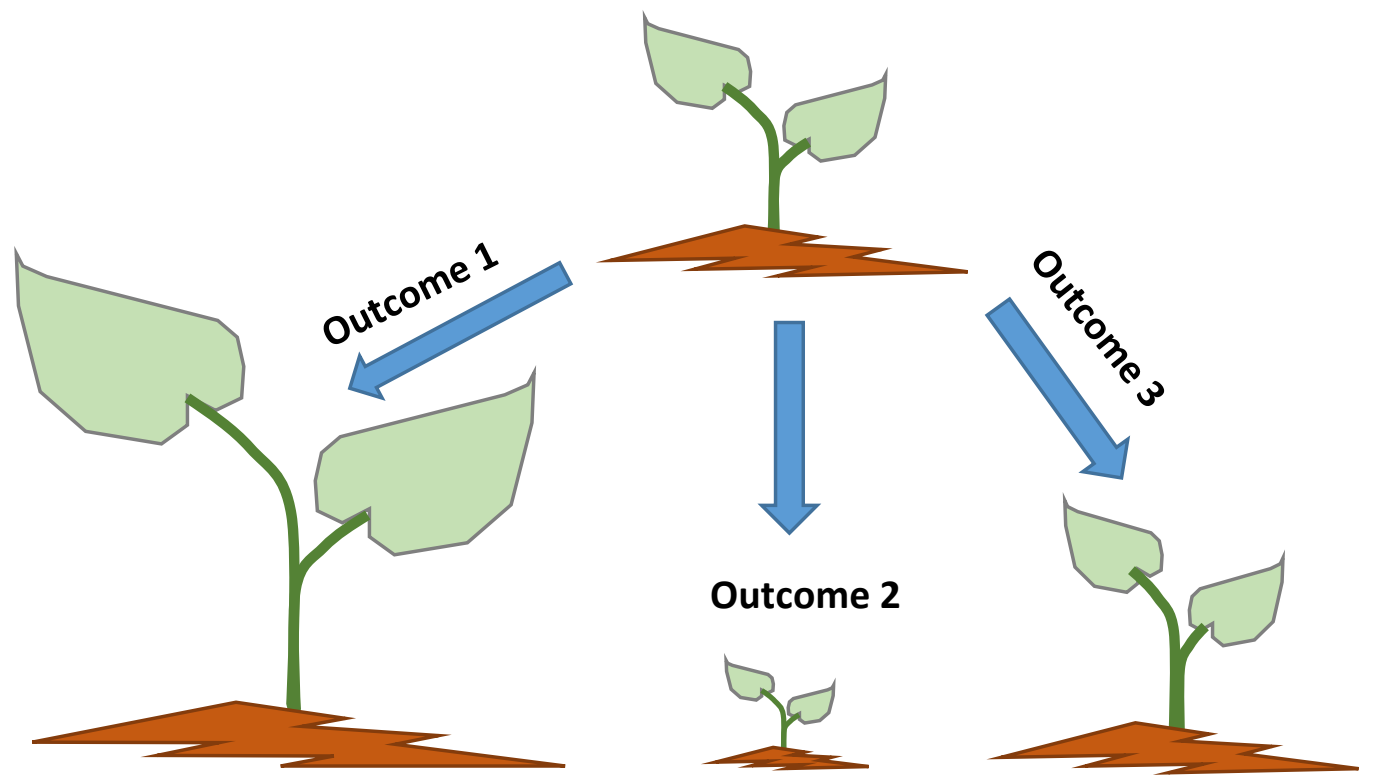

Figure 1.3 The three evolutionary scenarios for trait size changes. Outcome 1: divergent group becomes larger in size. Outcome 2: divergent group becomes smaller in size. Outcome 3: divergent group stays the same in size, and displays non-size related change. 


\section{The Island Rule}

\section{History}

Foster (1964) demonstrated that large mainland animals including lagomorphs, carnivores and artiodactyls displayed insular dwarfism, while small animals like rodents and marsupials displayed gigantism on islands compared to their closest mainland counterparts. Van Valen in (1973) termed this phenomenon the 'Island Rule'. Later, Heaney (1978) and Lomolino (1985) specified that the rule was better described as a gradual trend among species of different body size. However, the Island Rule is still often generalised to "big species get small, small species get big", (See Figures 1.4).

The Island Rule in a graphic form displays a 'shift' where the diversity of an island is greatly reduced compared to the diversity of the mainland. Scholars have interpreted these evolutionary shifts as communities coming back to a median or an optimal functional zone (Brown, Marquet \& Taper, 1993; Damuth, 1993; Raia \& Meiri, 2011). That is to say, if an island's small species increase in size and big species decrease in size, overall the total size range of this island 'moves away' from extreme values. Therefore, as variation in size decreases, the values themselves become closer towards a common average. Island variation is usually contained within the variation limits of the mainland, thereby being an optimisation zone.

While studies by Lomolino and other academics (see Lomolino, 2006) have demonstrated multiple examples of support for the Island Rule, there continue to be critiques. Meiri, Cooper \& Purvis (2007), comment on the Island Rule's tendency to report clade-specific responses to insularity, and that the graded trend can be explained according to taxonomy. In fact, there have been multiple instances where the Island Rule has 'failed' to be the best explanatory principle (Welch, 2008; Itescu, Karraker, Raia, Pritchard \& Meiri, 2014). Concern has been raised, especially for animal studies, that human propensity to move species and cause localised extinctions may 'blur' the true extent of insular patterns of evolution (Faurby \& Svenning, 2016). Critiques of the Island Rule in animal species, continue to arise. In the last few months, Lokatis \& Jeschke (2018) published a paper outlining how support for the Island Rule in literature may be connected to bias from authors. Gould (1997), in discussing Cope's rule of organism body-size evolution, stated that focusing on extremes tends to intrigue the mind more than the full range of variation. Along a line of reasoning, Meriri, Raia and Phillimore (2011) proposed that perceived insular body size pattern may simply reflect an ascertainment 
bias. In order to have a full and legitimate investigation of the Island Rule, it is important to involve as many replicates as possible to eliminate this potential source of conflict. Lokatis and Jeschke (2018) state that with potential sources of bias in some papers, the Island Rule is well empirically supported in only half of the studies, although it tends to be better supported when restricted to mammals. Remarkably, the Island Rule as a concept has been greatly considered with respect to animals, without very much examination of the Rule in other areas such as plants.
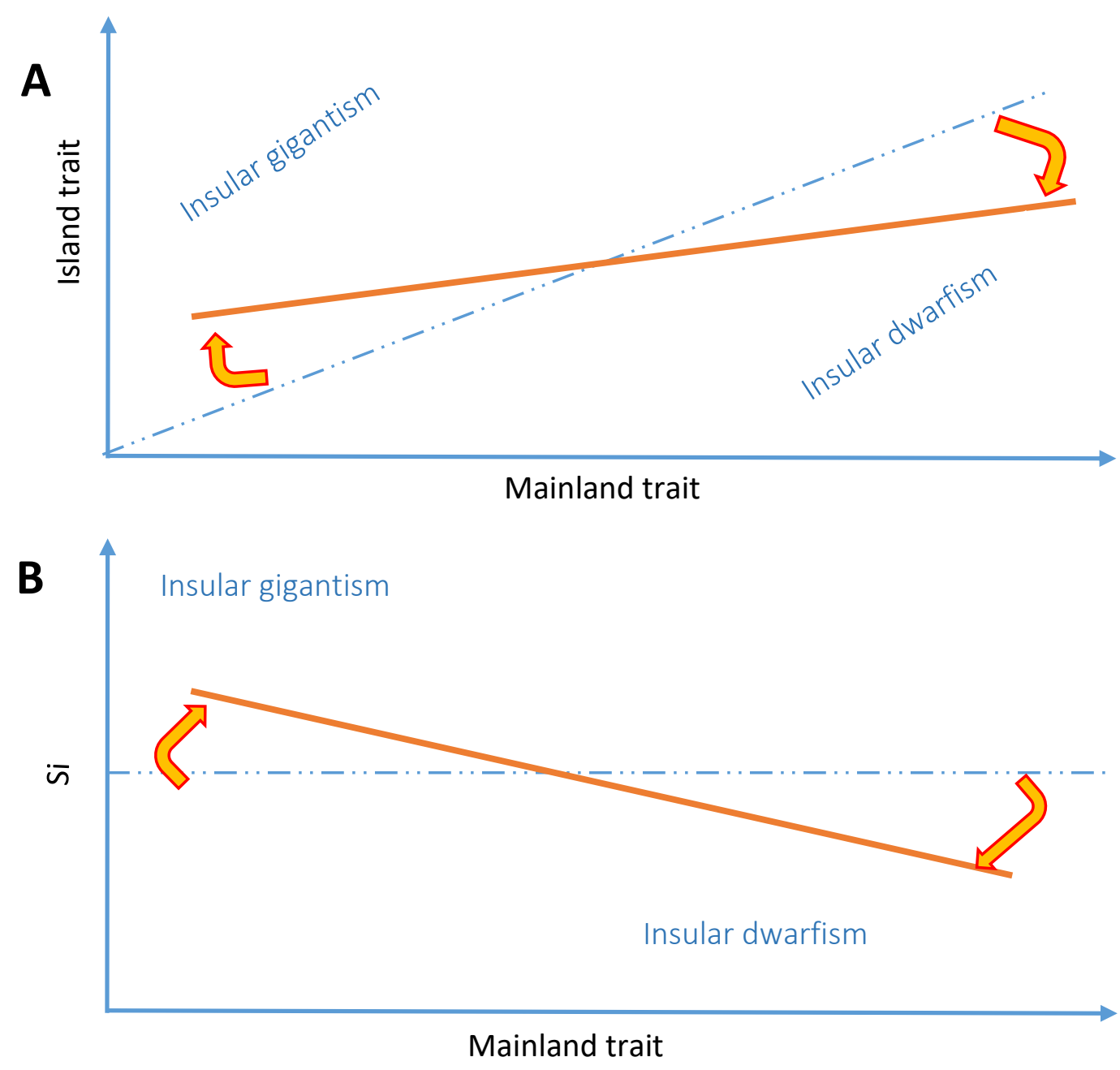

Figure 1.4 An illustration of the Island Rule displayed in two ways.

A) Island represented as a function of Mainland, where the orange line is a suggestion of a data trend indicating Island Rule.

B) The Si Ratio (where Si =Island size of measured trait /Mainland size of measured trait) compared to Mainland value.

The dashed blue line represents that Line of Isometry where Island values = closest Mainland relative values. The arrows indicate how the island species population have shifted away from the line of Isometry, demonstrating gigantism for smaller species, and dwarfism for larger species (relative to their closest mainland relative). 


\section{Patterns and processes}

The pattern of Island Rule is a spectrum of insular gigantism to dwarfism resulting respectively from small to big mainland relatives. This means that there are also intermediate insular species that 'stay' intermediate in comparison to their closest mainland relative. The Island Rule pattern is inferred to reflect dissimilarities in selective pressures (Lomolino, 2006). However, this is a somewhat simplification of the nature of evolutionary forces acting upon island phenotypes. Differentiation of island traits is invariably dependant on a number of processes such as founder events, small population size and limited gene flow (Bossdorf et al., 2005). The nature of these processes means that different evolutionary forces (such as genetic drift) may be acting on the evolution of island plants. Such island evolutionary histories would likely differ at species and trait level. While it is simple to present these concepts as potential drivers of insular size evolution they can be difficult to research.

In order to understand differences in size morphology, the two distinct features in the Island Rule (dwarfism and gigantism) have been separated to focus literature and understanding specific to each distinction. In plants there are no delineation to classify a plant as a dwarf or giant. The closest defined term is dwarfing, through intentional or natural processes a cultivar of plants become significantly smaller than the standard (Milach \& Federizzi, 2011). Therefore, to understand size changes on islands, a standard is required. The best standard to use in this instance is the closest mainland relative to an island endemic plant species. This process assumes mainland traits have a static phenotype, and that island species are not the result of evolutionary mechanisms such as phenotypic plasticity, local adaptation. This is a robust assumption, as describing a species in science is rigorous, meaning endemic island species are unlikely to be incorrectly described as a mainland species displaying phenotypic plasticity.

\section{Evidence of Insular Dwarfism - Why might species get smaller?}

Examples of dwarfism are less frequently noted in literature than examples of gigantism on islands (Lokatis \& Jeschke, 2018). Of dwarfism examples available, there is more literature and understanding of processes for animals compared to plants. Hanken and Wake (1993) state that miniaturization is common in multiple living and extinct taxa, especially "foraminiferans, nemertines, annelids, brachiopods, molluscs, arachnids, crustaceans, insects, echinoderms, and ascidians", though it seems most common and more pronounced in fish, amphibians and reptiles. Some small bodied mainland species have been most closely related to even smaller 
island species. Lawlor (1982) demonstrated how small seed-consuming rodents of the Peromuscus genus unexpectedly display dwarfism on islands. While on Jersey, the Channel Islands, Lister (1989) reported that teeth and limb bones of Red deer individuals (Cervus elaphus) were one-sixth of their size some 6000 years ago. In contrast, and somewhat more common are examples of large mainland species displaying island dwarfism. In particular, there are multiple cases of large mainland species such as elephant and hippopotamus species displaying dwarfism on islands (Roth, 1990; Poulakakis, Mylonas, Lymberakis, Fassoulas, 2002; Weston \& Lister, 2009; van der Geer, Lyras, Mitteroecker \& Macphee, 2018).

There is some empirical evidence in literature for insular dwarfism of plant species. Shinohara \& Murakami (2006) studied Blechnum and Lysimachia species isolated on 'alpine islands'. Their findings showed that these 'island' species compared to their 'mainland' counterparts down the mountain were significantly smaller. This smallness extended into the cellular scale, as the small 'island' species had a smaller size of epidermal cells present on the leaf. Burns (2016a) found that Alyxia ruscifolia (Apocynaceae) on Lord Howe Island displayed dwarfism in stature relative to the Australian Noosa Head population. Sun et al. (2016) also published similar work supporting the presence of dwarfism in Smilax biflora (Smilacaceae). Hendriks \& Burns (unpubl. data) considered all available endemic species on Cocos Island, Pacific Island (off the coast of Costa Rica) and found that they displayed dwarfism of both stature and leaf traits over all taxonomic groups compared to their closest mainland relatives. Studies of insular size changes tend to focus on plant vegetative features, and not necessarily link traits, meaning it can be difficult to identify what processes promote insular dwarfism.

Factors and processes that contribute to size changes difficult to disentangle. It is generally agreed that increased intraspecific competition, predation, and taxonomy are the major drivers of a vertebrate species' propensity to display island dwarfism (Palkovacs, 2003). However, our understanding of the mechanisms for vertebrate species does not necessarily translate to plant species.

On islands, there are multiple theories as to why dwarfism may occur in plant species. These can be generally split into two camps; Biotic and Abiotic factors. Biotic factors may include competition, co-evolved partners, and resource availability. Greater interspecific competition on a size restricted island, means that individuals that reproduce quicker could gain an evolutionary advantage. However, in reaching sexual maturity quicker, such species 
tend to display long-term dwarfism (Palkovacs, 2003). It is known that pollinators act as selective agents on floral traits (Inoue, Maki \& Masuda, 1996). Islands are known to have less available pollinators compared to the mainland in terms of sheer volume and also species diversity (Barrett, 1996), therefore floral features could respond to a reduced set of generalist pollinators by having smaller, less specialised flowers. In computer simulations, of island biomass-limitation, small body size was more likely to occur than gigantism (Wassersug, Yang, Sepkoski \& Raup, 1979). Abiotic factors that might impact on insular size changes could include climatic factors (such as temperature or wind exposure), habitat or substrate quality as a reflection of island quality. There is some evidence that climatic factors (such as a warmer temperature) may result in decreased stature and leaf size, as Leger (2013) showed when comparing a list of the same species between 1900 and 2000. The island itself in terms of substrate availability or general habitat may also play a role in selecting for individuals resulting in speciation and potentially size modifications. The Lord Howe Island palms are an example of speciation that probably arose due to differences in soil substrates (Savolinen et al., 2006).

In short, the given reasons available for why plant species may reduce in size when on an island include reduction in resources, potential pollinator effect, substrate quality, or habitat. These factors on their own, or as multiple parts of a system together with other unmentioned mechanisms, may result in the potential for island species to display dwarfism relative to their mainland counterparts. In these described instances dwarfism is favoured through natural selection. Such feedback systems could explain species' dwarfism over time, as smaller individuals would continue to be favoured.

\section{Evidence of Insular Gigantism - Why might species get bigger?}

Gigantism is most often reported for insular species (Lokatis \& Jeschke, 2018). Reporting bias can be misleading, as gigantism seems to be less common or advantageous for insular species (Lomolino, 2005). This in part may be a reflection of people being intrigued by the odd and unusual (Lokatis \& Jeschke, 2018). Of insular gigantism examples available, there is more literature and understanding of processes for animals compared to plants. The flagship lineage for animal insular gigantism is birds, especially in New Zealand. New Zealand has many large, flightless birds related to smaller flighted birds (Daugherty, Gibbs \& Hitchmough, 1993; Clout \& Craig, 1995; Lomolino, 2005). Flighted birds such as the Haast eagle and Eyles's harrier demonstrated gigantism and are most closely related to small Australian birds of prey (Bunce 
et al, 2005 in Evans, 2018). Further examples of insular gigantism include testudinidae, both fossil, and extant species such as the Galapagos tortoises which outweigh and outsize mainland relatives (Jaffe, Slater \& Alfaro, 2011). There are further peculiar examples of already large species displaying insular gigantism such as the Kodiak bear Ursus middendorffi (Meiri, 2004), and the extinct Crete deer Cervus major (Sondaar, 1977).

Island gigantism specifically pertaining to plants has been reported in literature. Böhle, Hilger and Martin (1996) used molecular data to infer the evolution and island colonization of Echium L. (Boraginaceae). This study showed that island plants displayed secondary woodiness or gigantism on oceanic islands compared to their closest mainland relatives, in line with a 'weeds-to-trees' phenomenon (Carlquist, 1974). Similar studies to Böhle et al. (1996) have been conducted and also found that gigantism in island species seemed to be more common for plant stature (Panero, Francisco-Ortega, Jansen, Santos-Guerra, 1999). In fact, studies by Carlquist (1974), Grant (1998), and Percy \& Cronk (2002) all noted this observation in their research. There is still further research that finds evidence that secondary woodiness in herbaceous plant species is a repeated evolutionary pattern (Lens, Davin, Smets \& del Arco, 2013; Crawford \& Archibald, 2017; Whittaker, Fernández-Palacios, Matthews, Borregaard \& Triantis, 2017). Contrary to expectations, research supporting gigantism in island plant leaves did not find any evidence of woodiness (Burns et al., 2012). Research from Cox \& Burns (2017) has shown that leaves on Chatham Island species showed stronger evidence for island gigantism than plant stature, which was also greater for the island species compared to their closest mainland relative. Kavanagh \& Burns (2015) also found that leaves are significantly larger on islands. Other traits, such as seed size has also been demonstrated to increase on islands through inter-specific comparison (Kavanagh \& Burns, 2014). These studies demonstrate the multiple specific features of plants that can display gigantism, with stature being the most frequently reported. Unfortunately, potential mechanisms driving this gigantism in vascular plant species remain elusively difficult to disentangle.

The most common mechanisms for gigantism are generally attributed to reduced resource interspecific competition, relaxed predation pressures, and higher quality resources (Lomolino, 2005). Palkovacs (2003) suggested that because large animals are generally more difficult to predate on, gigantism may offer reduced extrinsic mortality. However, for plants 
(similar to plant dwarfism) there is limited understanding of the patterns and mechanisms resulting in insular gigantism.

Explanations for processes fostering insular gigantism (similar to dwarfism) can be grouped as biotic or abiotic in nature. Biotic explanations seem to solely rely on one explanation; absence of herbivory. In the absence of herbivory, plants no longer need to be adapted to being small, and inconspicuous to avoid predation (Bowen \& Vuren, 1997). A relaxed predation pressure, may allow species to get bigger. Alternative explanations are abiotic in nature, and comprise of niche availability, island quality, climatic stimuli, or taxonomic predisposition (Williamson, 1983). In a new location with available niches, gigantism may be a reflection of the evolution of a species maximising available space, especially with reduced inter-specific competition, but increased intra-specific competition. Factors arising from island settings may influence plant sizes. Louw (2016), found that altitude seemed to influence the size of selago cushions, in such a way that the higher the altitude, the taller the selago cushion. It may be that climatic factors promote the evolution of gigantism in a lineage, although Burns et al. (2012) disagree citing release from predation and increased intra-specific competition as being more pertinent explanations. Insular gigantism on islands may reflect the unique island assemblages that form, and the evolutionary response that certain species have to these settings. It might be that certain lineages have a tendency towards either gigantism or dwarfism (Itescu et al., 2014; Welch, 2008).

In short, the main reasons given for insular gigantism seem to be increased resources, potential relaxed predation and competition pressures. While other mechanisms and considerations may explain why gigantism of traits occurs, in the previously described instances, larger individuals may be favoured through natural selection. Such feedback systems could explain species' gigantism over time, as bigger individuals would continue to be favoured.

\section{The Island Rule and Plants}

Whilst somewhat general, the Island Rule eloquently explains the complex nature of islands and the evolutionary processes occurring on them. Descriptions go as far as suggesting it is the simplest ecotypic rule used to explain nature (Van Valen, 1973). For this reason, its quick adoption and also vigorous debate has led to multiple different scopes and perspectives, especially in insular animals. At its essence, the theory deals with understanding if islands (and 
the evolutionary forces associated with them) 'select' for an optimum body size, or rather an optimisation of body size (Case, 1978). This is demonstrated with a reduction of size range on islands compared to the mainland.

Insular plant size changes have not been extensively investigated. In all truth, even just understanding the evolution of insular plants is generally required, with most studies focused on emblematic island animal taxa. Available plant literature has tended to focus on size changes to seeds and fruits, or arborescence (Hochberg, 1980; Kavanagh \& Burns, 2014). Arborescence is the demonstration of the susceptibility of herbaceous mainland species to display gigantism and insular woodiness, which is frequently reported (Carlquist, 1980; Wagstaff et al., 2010). However, species on satellite islands off New Zealand display a tendency for gigantism, notable for both leaves and stature irrespective of woodiness (Beever, 1989; Burns et al., 2012; Cox and Burns, 2017).

There has also been study conducted considering insular seed size. Kavanagh \& Burns (2014) found that insular seed size tended to display gigantism, and that this reflected the growth form of the plant species. Further investigations by Cox and Burns (2017), found support for Kavanagh \& Burns' 2014 study, with a tendency for gigantism found in insular seeds. Additionally, the study also found that there was a trend for larger island seeds for species with larger taxonomic divergence times. Dispersive features such as seed and fruit were not considered in this study, because there was not a large availability of data, from new sources or species that would significantly enhance the literature currently available.

Studies have shown that insular dwarfism in plants occurs (Shinohara \& Murakami, 2006; Burns, 2016a; Sun et al., 2016). Gigantism in insular plant species has also been observed (Carlquist, 1974; Böhle et al., 1996; Grant, 1998; Panero et al., 1999; Percy \& Cronk, 2002; Kavanagh \& Burns, 2014; Kavanagh \& Burns, 2015). However, studies that tie the two together to better understand the graded trend of the Island Rule are significantly less (Kavanagh \& Burns, 2014; Cox \& Burns, 2017; Hendriks \& Burns, unpubl. data). Such observations focus on stature, leaf size, and seed size while other morphological features are generally overlooked; in particular floral components. Irrespective of the features observed, very few have examined the underlying mechanistic forces that act on evolution of insular plant size changes.

The aim of this thesis is to ascertain if the Island Rule is applicable to plants, considering multiple morphological characters. Further, for the first time, an insular floral size range 
reduction will be investigated in light of the Island Rule. Understanding evolutionary patterns improves our knowledge of evolution. Investigation of the drivers of evolutionary size change improve scientific endeavours for modelling systems to better predict the future impact of climate change for plants.

\section{Thesis overview}

In this thesis, I explored evolutionary patterns in ten different plant traits on islands in the South Pacific region. The approach taken was a 'species pairs' (island-mainland) comparison, where insular taxa were directly compared to their mainland sister taxa. Data was collected from flora descriptions and herbaria measurements. As the format is similar for each data chapter there may be some repetition, particularly for methodology and introductions.

In chapter 2, I tested for differences in floral features, split into seven categories (flower, inflorescence, petal, sepal, filament, anther, and pedicel). Floral data was sourced from literature, and herbarium measurements to produce data sets for each individual category. After testing to see if there was an overall trend for evolutionary changes in the various traits of flower anatomy using simple regression models, I then tested if size variation could be explained by additional factors. Finally, I tested multiple random factors to understand if they were major influencing factors in insular size changes.

In chapter 3, I tested for differences in vegetative features, split into maximum stature, leaf area and petiole length. Vegetative data was sourced from literature and literature, to produce a comprehensive data set. As mentioned for chapter 3, 'species pairs' were created for insular taxa and their sister mainland taxa. After testing to see if there was an overall trend for evolutionary changes in the various traits of flower anatomy using simple regression models, I then tested if size variation could be explained by additional factors. Finally, I tested multiple random factors to understand if they were major influencing factors in insular size changes.

In chapter 4, I consolidate the findings of the thesis, and how each set of features compare against one another. Overall through exploring trait specific evolutionary changes in plants this thesis is able to broaden our understanding of insular evolutionary processes and outcomes. 


\section{Chapter 2: Floral features}

\section{Introduction}

A popular observation on islands is the occurrence of small flowers. In referring to the Aru Islands in Indonesia Alfred Russel Wallace (1832) wrote that "tropical flowers are less abundant, on average less showy, and are far less effective in adding colour to the landscape, than in temperate climates". Expressing a similar sentiment, the flora of the Galapagos Islands was described by Charles Darwin (1835) as having no large flowers. The common occurrence of small flowers was a notion that Alfred Wallace held dear for more than four decades, as the 1876 description of his travels through Asia reported that the flowers were essentially one type throughout. They have been further been described as small and inconspicuous (Carlquist, 1974; Grant, 1998). Insular flower size continues to be reported in more recent literature. Investigations into the angiosperms of the Juan Fernández Islands (Chile), found that the majority of flower sizes $(60 \%)$ were small $\left(\leq 26 \mathrm{~mm}^{2}\right)$ (Bernadello, Anderson, Stuessy \& Crawford, 2001). While on the Izu Islands of Japan, plant species also display evidence of floral dwarfism (Kamijo \& Hashiba, 2003). Such observations and studies only considered size change within a species (essentially testing for island plasticity). However, my research considers the evolutionary changes of flower size between closely related mainland and island species.

Island flowers are not all small and inconspicuous though, in fact some cases display gigantism. On the Izu Islands for example, while some species (did indeed) display dwarfism, others display gigantism (Kamijo \& Hashiba, 2003). The megaherbs on the sub-Antarctic Islands south of New Zealand are a great example of flower gigantism. Hooker (1847 in Fell 2002, p. 53) was one of the first naturalists to record megaherbs on the sub-Antarctic islands. In his description of the plants he stated that the Pleurophyllum meadow produced "a floral display second to none outside the tropics". Large flowers in the sub-Antarctics is a story of repeated evolutionary form occurring multiple times across a number of lineages (Mitchell,Meurk \& Wagstaff, 1999), a fact which has drawn scientific attention toward megaherb study in more recent years (Lord, 2015; Little, Eidesen, Müller, Dickinson \& Lord, 2016). Therefore, evidence of both gigantism and dwarfism of flower size exists on islands.

Not only did naturalists and scientists document instances of islands generally differing from the mainland, but they also commented on broad trends they believed were occurring 
across latitude. A frequent historic view of floral sizing was that tropical regions display large showy flowers, with less tropical regions display more generalist flowers. A generalist flower as being typically denoted as drab (often green or white), small and inconspicuous (Ollerton, Killick, Lamborn, Watts \& Whiston, 2007). In Indonesia Alfred Russel Wallace (1832) described his expectation of tropical climates to be abundant with showy coloured flowers. While on Chatham Island (Galapagos) Charles Darwin (1835 in Brown, 2010; p. 301) wrote that he had only come across a handful of flowers so ugly and insignificant, he felt that they were better suited to occurring in Arctic Circle rather than an equatorial island. These reports by Wallace and Darwin, indicating that flower size may differ as a function of latitude, were never followed up with quantitative empirical study. There is some evidence that latitude may influence size morphology in animals according to Bergmann's rule due to climatic or geological differences (McNab, 1971; Blackburn, Gaston \& Loder, 1999); therefore, it is possible that flower size may differ according to geographic location (and/or) latitude.

The Pollinator Potential Paradigm is introduced as a novel potential explanation for insular size patterns of flowers. The hypothesis states that reduced island pollinator diversity results in reduced floral size variation. Considered 'subsets of the mainland' island biotas tend to support less species diversity, and consequently less pollinator diversity, compared to that of the continental landmasses (Olesen \& Jordano, 2002; Bellemain \& Ricklefs, 2008). Samples often do not reflect the full variation in a population. Therefore, a subset of pollinators from the mainland will most likely represent a reduced variation of pollinator body size. This means that the potential body size range of pollinators on islands is reduced comparative to the mainland. Plants and pollinators are highly co-evolved. Flower size is usually indicative of pollinator type and size (Jordano, 1987; Herrera, 1989; Barrett, 1996; Hu, Dilcher, Jarzen, \& Taylor, 2008; Futuyma, 2009). Pollinators can act as selective agents on floral traits (Inoue, et al., 1996). Wallace (1891) demonstrated that islands with low numbers of bee and butterflies also have a low number of big showy flowers. Therefore, reduced island pollinator communities may reduce flower size on islands.

It is possible to theoretically model the Pollinator Potential Paradigm. The foundation of the model is that a group of islands of the same size exists, each increasingly further from the mainland. Each island receives a certain number of potential immigrants from the mainland, with the island closest to the mainland receiving the most, and the furthest island 
receiving the least. This could occur through stepping stone dispersal (Yamada, Kodama \& Maki, 2014). The mainland population is assumed to have a normal distribution, and islands receive a random subset of this population. The closest island to the mainland receives a greater number of pollinator species and therefore a greater diversity in body size range, while the furthest island receives the least species and consequently, the least diversity in body size range (see Figure 2.1). The concepts and logic of this paradigm appear to be supported by basic mathematical modelling (Burns, pers. comm.)

The paradigm could be applicable to the dataset if the standard deviation of the size range of a given island floral feature is smaller than that of the mainland. There is greatest support for the Island Rule, when the body size range of island pollinators is smaller than the body size range of mainland pollinators. Islands with a smaller subset of the initial population are more likely to have reduced body size range diversity, meaning that potential patterns for the Island Rule are more pronounced. As the body size diversity of an island approaches the body size diversity of the mainland, the distribution of the size range becomes more equal on both axes. Resulting in outcomes that do not follow the Island Rule pattern.

The Pollinator Potential Paradigm has been recognised in part by previous works, in particular Inoue (1990) proposed that low pollinator availability may explain small flowers on the Izu Islands, Japan. Certainly, studies like Olesen \& Jordano (2002) found that islands have less diversity of pollinators compared to the mainland. Rather than be explained by evolutionary processes, it is hypothesized here that reduced insular size diversity relative to the mainland may simply be explained by the nature of stochastic chance, and the probability that subsets invariably fail to represent the source population's full diversity.

In this chapter, following the unique opportunity to contribute towards an unsaturated topic I test for the patterns of size range reduction in floral features. The Pollinator Potential Paradigm (as explained here) is one hypothesis which may explain a reduction in size range of floral species. The presence (or absence) of a size change pattern were considered with additional climatic, biological or geographical information. To evaluate evolutionary insular size changes, the following predictions were tested using linear regressions: (1) Flowers of endemic island species will display reduced size diversity compared to their closest mainland relatives (2) Does a pattern occur irrespective of latitude, (3) other factors will not be statistically meaningful in understanding the Island Rule. 


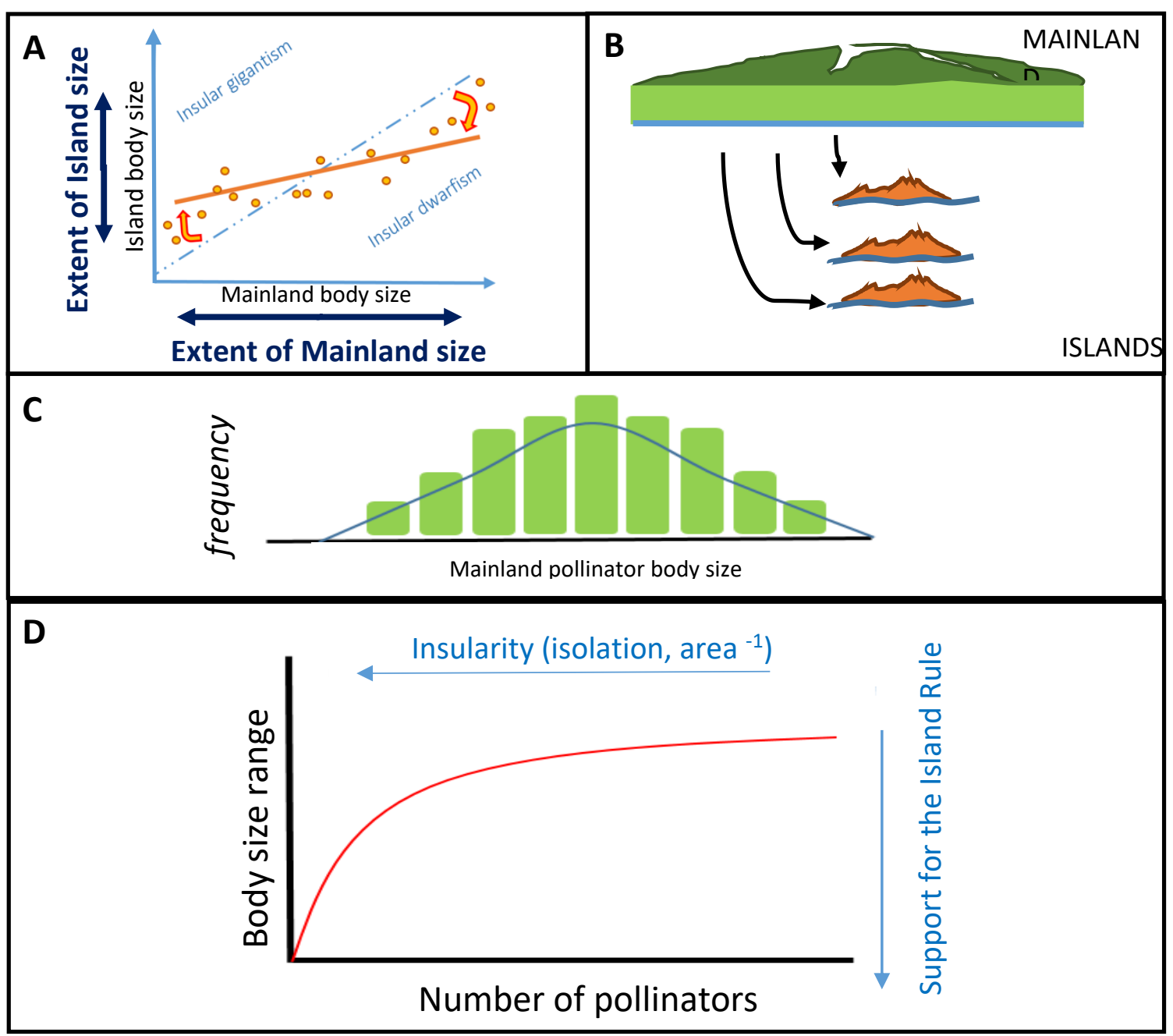

Figure 2.1 An illustration of the Pollinator Potential Paradigm.

A) Graphic interpretation of reduced pollinator size diversity on islands, compared to a larger size diversity of pollinators on the mainland

B) Distribution of pollinators from mainland to an island. A group of islands of the same size each increasingly further from the mainland. Each island receives a certain number of potential immigrants from the mainland, with the island closest to the mainland receiving the most, and the furthest island receiving the least.

C) Normal distribution of mainland pollinator body size. Islands receive a random subset of this population.

D) Curve showing the range of body size for a given subsample of mainland pollinators. The closest island to the mainland receives a greater number of pollinator species and therefore a greater body size range, while the furthest island receives the least. Insularity can be expressed as both isolation and geographic size. Large islands are statistically similar to close islands, just, as far islands are to small ones. 


\section{Methods}

\section{Study site}

New Zealand was used as a central 'mainland' feature, and only islands within $1800 \mathrm{~km}$ of the coast were included. The islands contained in this geographical area were identified as having species that most likely originated from New Zealand. New Zealand (and the islands around it) have a long history of geological isolation. New Zealand and its islands isolated from Gondwana about 80 million years ago. Lord Howe, Norfolk and Macquarie islands are 7 million, 2.5 million and 300,000 years old respectively, having arisen through undersea volcanic activity. Terrestrial taxa arriving to islands all had to disperse overwater. However, land bridges may have connected some of the smaller islands around New Zealand and aided in species dispersal (Diamond, 1984; Waters \& Craw, 2006). The islands considered for this study included; Antipodes, Auckland, Bounty, Campbell, Chatham, Kermadec, Lord Howe, Macquarie, Norfolk, Snares, Stewart and the Three Kings (see Figure 2.2).

\section{Species Selection}

Determination of endemic Island plant species

A phylogenetic comparative method was undertaken in order to assess the evolutionary hypothesis of a reduction in insular size variation. In order to compare deep evolutionary time, extant island endemics were compared to their closest extant mainland relative. Checklists were compiled for all insular endemic plant species known to exist on the 12 Island groups. (See Table 2.1 below and appendices for lists, species pairs and references).

\section{Determination of closest mainland relative}

Closest mainland sister taxa were identified through molecular phylogenies where they were most closely related to a 'checklist' endemic species. Only information from phylogenies that gave rise to one closest mainland relative were used, creating 'species pairs', all other phylogenies were unusable (refer to Figure A1 (Appendix A) for examples of suitable and unsuitable phylogenies). Of a potential dataset of 274 endemic plant species, 148 were included in molecular phylogenies. However, of that only 65 of those studies (from 9 islands) produced results that allowed them to be included in the study (refer to table 2.1). For the purposes of this study, it is assumed that the relevant phylogenies collected do not display issues of non-independence between different species (i.e. the true patterns of relatedness are represented in the phylogeny). Further research undertaking phylogenetically independent contrast analysis, could account for any issues of non-independence in phylogenies. 


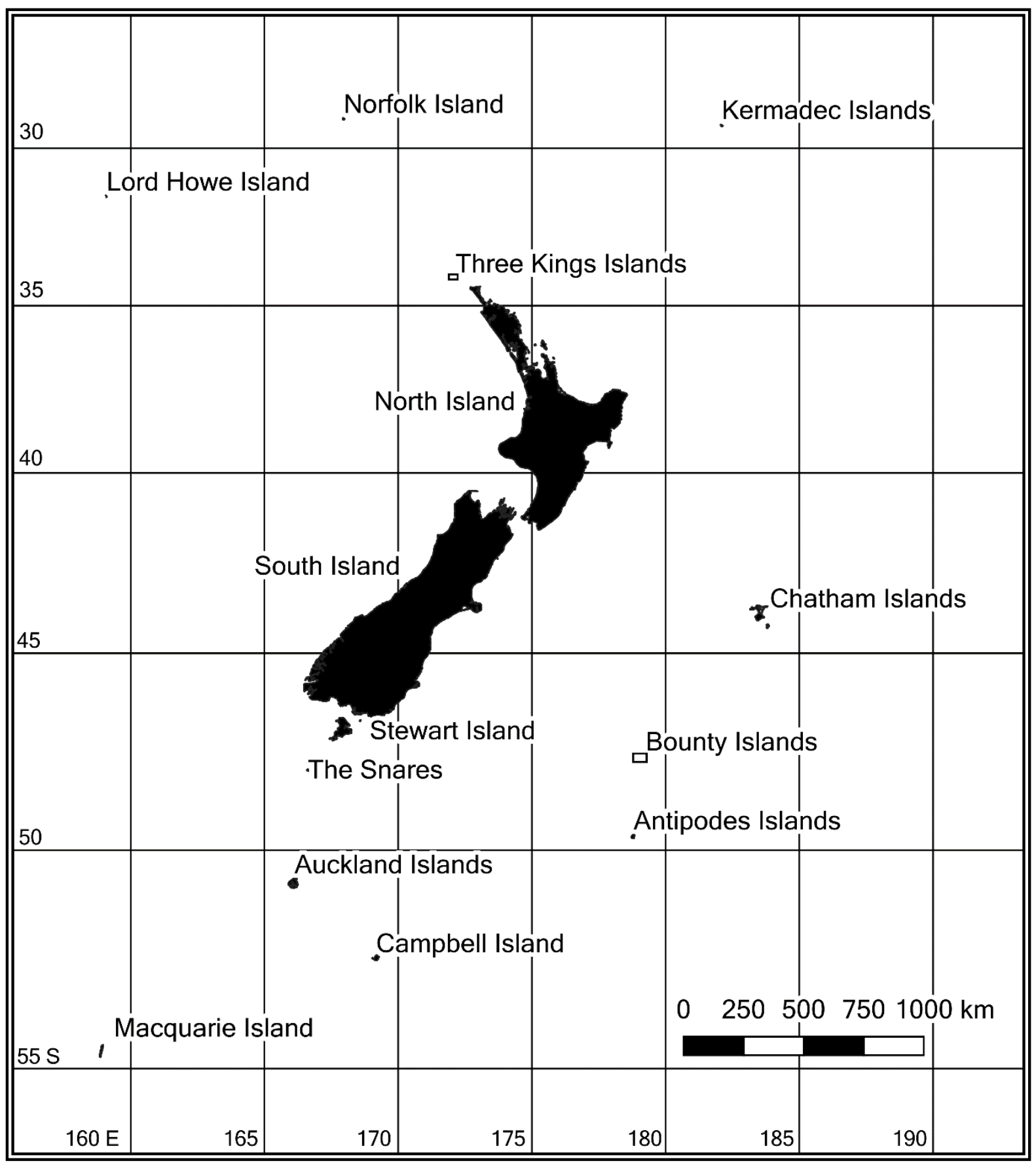

Figure 2.2 Map of islands around New Zealand included in this study. 
Table 2.1 The breakdown of species representation from identified islands of interest

\begin{tabular}{|c|c|c|c|}
\hline $\begin{array}{l}\text { Island } \\
\text { Group }\end{array}$ & $\begin{array}{l}\text { Number of } \\
\text { endemic } \\
\text { vascular } \\
\text { plant taxa }\end{array}$ & $\begin{array}{l}\text { Number of taxa with } \\
\text { phylogeny (usable } \\
\text { phylogenies resulting } \\
\text { in } 1 \text { mainland relative) }\end{array}$ & Island taxa list reference(s) \\
\hline Antipodes & 5 & $1(1)$ & $\begin{array}{l}\text { Dosley (1989), New Zealand Plant } \\
\text { Conservation Network (NZCPN) } \\
\text { (2018), Rance (2018) }\end{array}$ \\
\hline Auckland & 10 & $5(2)$ & $\begin{array}{l}\text { NZCPN (2018), Phillips (2012), } \\
\text { Rance (2018) }\end{array}$ \\
\hline Bounty & 1 & $1(0)$ & Rance (2018) \\
\hline Campbell & 6 & $1(1)$ & NZCPN (2018) Rance (2018) \\
\hline Chatham & 40 & $35(17)$ & $\begin{array}{l}\text { de Lange (2013), Heenan et al. } \\
\text { (2012), NZCPN (2018) }\end{array}$ \\
\hline Kermadec & 25 & $14(9)$ & Nathan (2012), NZPCN (2012) \\
\hline Lord Howe & 109 & $60(21)$ & $\begin{array}{l}\text { Department of Environment and } \\
\text { Climate Change (NSW) (2007). }\end{array}$ \\
\hline Macquarie & 4 & $3(0)$ & NZCPN (2018) \\
\hline Norfolk & 41 & $16(11)$ & $\begin{array}{l}\text { de Lange et al. (2005), NZPCN } \\
\text { (2018) Flora of Australia (1994) }\end{array}$ \\
\hline Snares & 2 & $1(0)$ & NZCPN (2018), Rance (2018) \\
\hline Stewart & 14 & $3(1)$ & NZCPN (2018) \\
\hline Three Kings & 17 & $8(2)$ & NZCPN (2018), Wright (1982) \\
\hline OVERALL & 274 & $148(65)$ & \\
\hline
\end{tabular}

\section{Collection of morphological measurements}

Data only included measurements from adult specimens, (i.e. mature reproductive individuals). Trait measurements primarily came from literature or herbaria specimen measurements (see list of sources in Appendix A). This was appropriate for most cases. For some species, relevant data was printed in non-English languages; if this was easily translatable, then this data was used. Morphological features considered for this study included floral features (average flower area, average petal area, average sepal area, maximum inflorescence length, maximum filament length, maximum anther length, and maximum pedicel length). Further detail on each morphological feature for how it is specifically defined and measured can be found under the 'floral measurement' heading, Box 2.1. These features were selected primarily as they were the floral traits most commonly reported on. Some traits (such as petal size) are obviously related to pollinator attraction and interaction. However, other features, such as sepal area or pedicel length can also impact pollination potential (big sepals or a small pedicel, may result in obscuring the flower). Testing of multiple traits ensures that results are not bias by one trait. 
Where trait measurements were not published, herbaria presses were referred to. In particular, specimens were measured at Auckland War Memorial Museum (AK) and Te Papa (WELT) herbariums. In cases where access to digital herbarium specimens were required, dried measurements could be measured using the image software Image J. A minimum of five measurements for each morphological feature was required for each specimen that was measured from herbarium presses. Measurements came from all available structures on herbaria sheets, and as many independent individual plants as possible. There was a preference for physical measurements from herbaria specimens, rather than online (again refer to Appendix A to see which measurements these were).

Each of the trait data sets contained a mixture of herbarium measured and floralistic literature derived species pairs. Species pairs themselves reflected only one measurement type. Datasets of both herbaria based and flora based measurements have been proven to not cause statistically significant issues (Kavanagh 2015; Cox \& Burns 2017). Regardless, the source of measurement origin was considered as a random factor for linear mixed models (see Appendix $B$ for source of measurement references). For some flora it is unclear if the measurements come from fresh or dried specimens, it is assumed that flora are compatible and follow similar rigorous standards in order to provide a true representation of the morphology of plants.

\section{Floral measurements}

All angiosperms were considered that had perfect hermaphroditic flowers, additionally species exhibiting imperfect flowers (i.e. monoecious or dioecious) were included where the measurements for both functional male and functional female flowers could be collectively averaged. 


\section{Floral measurement definitions}

\section{BOX2.1}

\section{Flower area}

Average flower area was measured as flower length (length from pedicel attachment to the tip of the petals) $x$ flower width (maximum distance perpendicular to the length measurement at the widest point of the flower). The island-mainland species pair sample size for flower area was $n=35$.

\section{Inflorescence length}

Maximum inflorescence length was measured as maximum length from point of attachment to the rest of the plant to the tip of the inflorescence. The sample size inflorescence length was $n=24$.

\section{Petal area}

Average petal area was measured as the average length (length from attachment to the base of the flower unit to the tip of the petals) $x$ average petal width (maximum distance perpendicular to the length measurement at the widest point of the petal). The sample size for petal area was $n=$ 34.

\section{Sepal area}

Average sepal area was measured as average length (length from attachment to the plant to the tip of the sepal) $x$ average sepal width (maximum distance perpendicular to the length measurement at the widest point of the sepal). The sample size for sepal area was $n=34$.

\section{Filament length}

Maximum filament length was the total length of the filament from point of attachment to the flower unit, to the base of the filament. The sample size for filament length was $n=25$.

\section{Anther length}

Maximum Anther length was measured as (total length from attachment to filament to the tip of the anther). The sample size for anther length was $n=26$.

\section{Pedicel length}

Maximum pedicel length was the total length of the pedicel from point of attachment, to the point of attachment to the flower. The sample size pedicel length was $n=35$. 


\section{Statistical Methodology}

The sample size of a given plant trait (e.g. flower area) is a subset of the 65 available species depending on 1). If the species meets the given criteria for the measurement (as previously outlined and 2). If measurements for both the insular and mainland relative were obtainable. This means that the sample number of species in each analysis varies. All measurements were natural-logged before analysis (with the exception of latitude values - see below).

Analysis of the data generally followed the procedure of Lomolino (2005). Statistical comparisons between the island and mainland groups used the Ime4, Imodel 2 and car packages in the R environment ( $R$ Core Team 2013). Nine islands encompassing a $\sim 16,000$ kilometre area of the South Pacific are represented across ten datasets. Each of these differently sized islands have their own unique climatic and biological factors that could all potentially influence certain morphological features in plants. Such factors were integrated in different mixed model approaches.

Morphological size divergence (Si) was expressed as the trait measurement of an insular species divided by that of its genetically closest mainland relative's corresponding trait value. Lomolino (2005) outlines that this is a useful measurement for visualisation of the data for gigantism and dwarfism. This 'ratio' data was analysed through model 1 linear regression. Further, insular and mainland species traits were analysed through model 2 linear regression. This method avoids the potential repercussions of the Si ratio method, which may include "possible statistical problems and artefacts associated with regressions using ratios" (Lomolino 2005). Evidence supporting the presence of the Island Rule exists if the Model 2 regression trend for a trait results in an intercept $>0$ and a gradient $<1$.

Linear Regressions

Model 1 linear regression was undertaken on Si ratio data, with a general formula of:

$$
\operatorname{lm}(y \sim x)
$$

This formula is the basis for further linear mixed models to come. Here $\mathrm{x}$ variable was always mainland values, while y value was either Island values or Si ratio values. T values, $\mathrm{P}$ values and $R^{2}$ values were extracted using this method. 
Model 2 regressions were conducted on the island vs. mainland data with a formula of:

$$
\text { Imodel2(y } \sim x)
$$

This model is suitable, because island species vary as a function of mainland species (islands represent a subset of the mainland). This formula computed OSL (Ordinary Least Squares values). The results of this test gives an $\mathrm{R}$ value as well as a slope and intercept value for the trend of the data, along with the 95\% confidence intervals for these measurements. This allows the data trend to be statistically compared to the line of isometry (the line where island values $=$ mainland values).

Testing of additional biological, climatic or geographical factors

Statistical analysis was also run to examine if latitude or additional factors influenced insular floral size variation. These factors are described below in table 2.2.

Table 2.2 Biological, Climatic and geographical factors considered in analysis

\begin{tabular}{|c|c|}
\hline Factor & Description \\
\hline latitude & $\begin{array}{l}\text { Presented as a converted decimal degree value. Latitude measurements were taken from } \\
\text { the centre of each island mass, as an 'average island value' (see table } 2.3 \text { for latitude } \\
\text { reading and Figure } 2.2 \text { for a visual refresher). }\end{array}$ \\
\hline island & $\begin{array}{l}\text { The island of origin for an insular endemic species. Any large discrepancies as a result of } \\
\text { island may indicate environmental differences. }\end{array}$ \\
\hline measure & $\begin{array}{l}\text { Where the measurements came from. Either herbaria or a floral description. In order to } \\
\text { be statistically relevant each trait had to have at least six examples of factors where the } \\
\text { outcome was binary (e.g. measurement type is either herbaria or flora based). }\end{array}$ \\
\hline endemic & The total number of endemic plant species in total from the given island of occurrence \\
\hline order & $\begin{array}{l}\text { The total number of endemic plant species within the same taxonomic order from the } \\
\text { same island of occurrence }\end{array}$ \\
\hline type & The generic type of plant (e.g. shrub, tree, herb) \\
\hline Orderz & $\begin{array}{l}\text { The taxonomic order of a plant. This factor indicates if there are tendencies of the lineage } \\
\text { to display certain characteristics, regardless of the plant positioning in the landscape }\end{array}$ \\
\hline rainfall & Annual average rainfall of the island (measured in $\mathrm{mm}$ ) \\
\hline temp & Annual average temperature of the island (measured in Celsius) \\
\hline wind & Annual average wind speed $(\mathrm{km} / \mathrm{hr})$ \\
\hline size & Size of the island (measured in $\mathrm{km}^{2}$ ) \\
\hline \multicolumn{2}{|r|}{ Latitude readings are made up of three parts (degrees, minutes, seconds), with the latter two } \\
\hline \multicolumn{2}{|c|}{ being broken into 60 piece segments. To ensure that the graphics and statistical operations } \\
\hline \multirow{2}{*}{\multicolumn{2}{|c|}{ would interpret these values correctly, the distance for minutes was converted into tenths }} \\
\hline & \\
\hline & \\
\hline
\end{tabular}


$0.68 \times 10=68$ ), to a corresponding decimal degree of 49.68. Analyses used Model 1 linear regression, with a similar basic formula as for Si ratios with a formula of: Im (Si ratio factor).

Table 2.3 Island latitude values

\begin{tabular}{|c|c|c|}
\hline Group & Latitude value & Decimal degrees \\
\hline Antipodes & $49 * 41 ' 11 " S$ & 49.68 \\
\hline Auckland & $50 * 42$ '05'S & 50.70 \\
\hline Campbell & $52 * 32$ '09"S & 52.53 \\
\hline Chatham & $43^{*} 55^{\prime} 42^{\prime \prime S}$ & 43.92 \\
\hline Kermadecs & $29 * 15 ' 53$ "S & 29.25 \\
\hline Lord Howe & $31 * 32 ' 26 " S$ & 32.53 \\
\hline Norfolk & $29 * 02 ' 12$ "S & 29.03 \\
\hline Stewart & $46 * 57 ' 51$ 'S & 46.95 \\
\hline Three Kings & $34 * 09 ' 42 " \mathrm{~s}$ & 34.15 \\
\hline
\end{tabular}

\section{Results}

Analysis of Island Rule trend in floral features

Table 2.4 Specific statistical results table for each of the 3 indicator methods of statistical significance in different floral features.

\begin{tabular}{lcccc||cccc}
\hline & \multicolumn{4}{c||}{} & \multicolumn{3}{c}{ Model 1 } & \multicolumn{4}{c}{ Model 2 } \\
\hline $\begin{array}{l}\text { Morphological } \\
\text { feature }\end{array}$ & $\mathrm{t}$ value & $\mathrm{P}$ value & slope & $\begin{array}{c}\text { slope } 95 \% \\
\text { confidence } \\
\text { interval }\end{array}$ & t value & P value & slope & $\begin{array}{c}\text { slope 95\% } \\
\text { confidence } \\
\text { interval }\end{array}$ \\
\hline Flower area & -3.42 & $1.7 \mathrm{e}^{-3 *}$ & -0.39 & -0.63 to -0.16 & 5.02 & $8.8 \mathrm{e}-6^{*}$ & 0.58 & 0.36 to 0.82 \\
\hline $\begin{array}{l}\text { Inflorescence } \\
\text { length }\end{array}$ & -4.25 & $4 \mathrm{e}^{-4 *}$ & -0.69 & -1.04 to -0.35 & 1.78 & $0.04^{*}$ & 0.29 & -0.05 to 0.63 \\
\hline Petal area & -5.19 & $1.1 \mathrm{e}^{-5 *}$ & -0.53 & -0.74 to -0.32 & 4.56 & $3.6 \mathrm{e}-5^{*}$ & 0.47 & 0.26 to 0.68 \\
\hline Sepal area & -5.65 & $3.4 \mathrm{e}^{-6 *}$ & -0.69 & -0.94 to -0.49 & 2.49 & $0.009^{*}$ & 0.31 & 0.06 to 0.56 \\
\hline $\begin{array}{l}\text { Filament } \\
\text { length }\end{array}$ & -2.9 & $8.1 \mathrm{e}^{-3 *}$ & -0.31 & -0.53 to -0.09 & 6.5 & $5.7 \mathrm{e}-7^{*}$ & 0.69 & 0.47 to 0.91 \\
\hline Anther length & -3.32 & $0.003^{*}$ & -0.57 & -0.93 to -0.22 & 2.47 & $0.01^{*}$ & 0.43 & 0.07 to 0.78 \\
\hline Pedicel length & -3.41 & $1.7 e^{*} 3^{*}$ & -0.40 & -0.64 to -0.16 & 5.05 & $8.8 e-6^{*}$ & 0.59 & -0.44 to 0.22 \\
\hline
\end{tabular}

Analyses of floral measurements in vascular plants yielded consistent results. Regression results indicate that regardless of the regression models used, trends for each trait tested are consistent with that predicted by the Island Rule; i.e. a pattern from insular gigantism toward dwarfism as the mainland species size increased (with all 7 floral traits being consistent with the rule, significant at the 0.05 level; table 2.4). All floral feature slopes differed from a gradient 1 for Model 0 analysis, when considering the 95\% confidence level for the slope. While in a similar fashion, floral feature slopes differed from a gradient 1 for Model 2 analysis, when considering the $95 \%$ confidence level for the slope. 
Analysis of Island Rule trend in plants across additional biological, climatic or geographical factors

No observable pattern was recorded for six of the eleven factors in any of the floral features at the 0.05 level (measure, endemic, order, type, Orderz and temp). For these factors the null hypothesis cannot be rejected, indicating that the size of insular floral features are not impacted by any of the five mentioned factors. Statistical correlation for some traits were observed against the five remaining factors; latitude, island, rainfall, wind and size. Statistical outcomes for the analysis of Island Rule in plants across all factors considered can be found in Appendix B.

Analysis comparing latitude generally described no observable pattern in any of the floral features, except for inflorescence length, which did. Six of the seven floral features were not significant at the 0.05 level. For these six features the pattern of the Island Rule occurring on the islands seems to be independent of island latitude. For these six remaining features the null hypothesis cannot be rejected, meaning that there is no indication that floral features are impacted by latitude (see Appendix B). This indicates that the pattern of reduced insular size may act independently of latitude. Statistical significance indicating a correlation between latitude and maximum Inflorescence length was present at the 0.05 level ( $p$ value, 0.02). Statistical outcomes for the analysis of Island Rule in plants across latitudes can be found in Appendix B. It is worth noting that Lomolino (2005), states that statistics with ratios should be done cautiously (specifically with this application), as they may produce results that can be difficult to disentangle, given their statistical nature.

Statistical significance (at the 0.05 level) indicated a correlation between the factor island and three of the floral traits. These features were petal area, Inflorescence length, and flower size ( $p$ values, $0.02,0.03$ and 0.01 respectively). Statistics were replicated with the removal of islands which only had 1 representative. The replicated statistics showed no statistical significance for any of the traits (at the 0.05 level).

Statistical significance (at the 0.05 level) indicated a correlation between the factor size and three of the floral traits. These features were petal area, pedicel length and inflorescence length ( $p$ values of $0.01,0.02$ and 0.01 respectively). This was a positive correlation, for petal size and inflorescence length, with the greater the size of the island of origin, the greater the 
average size of the floral feature. There was a negative correlation, for pedicel length, with the greater the size of the island of origin, and smaller the maximum pedicel length.

Statistical significance (at the 0.05 level) indicated a correlation between the factor rainfall and maximum inflorescence length and average flower size ( $p$ values of 0.04 and 0.03 respectively). This was a negative correlation with the greater the average annual rainfall, the smaller the average size of the floral feature.

Statistical significance (at the 0.05 level) indicated a correlation between the factor wind and two of the floral traits. These features were petal area and flower size ( $p$ values of 0.01 and 0.003 respectively). This was a negative correlation with the greater the average annual wind speed, the smaller the average size of the floral feature.
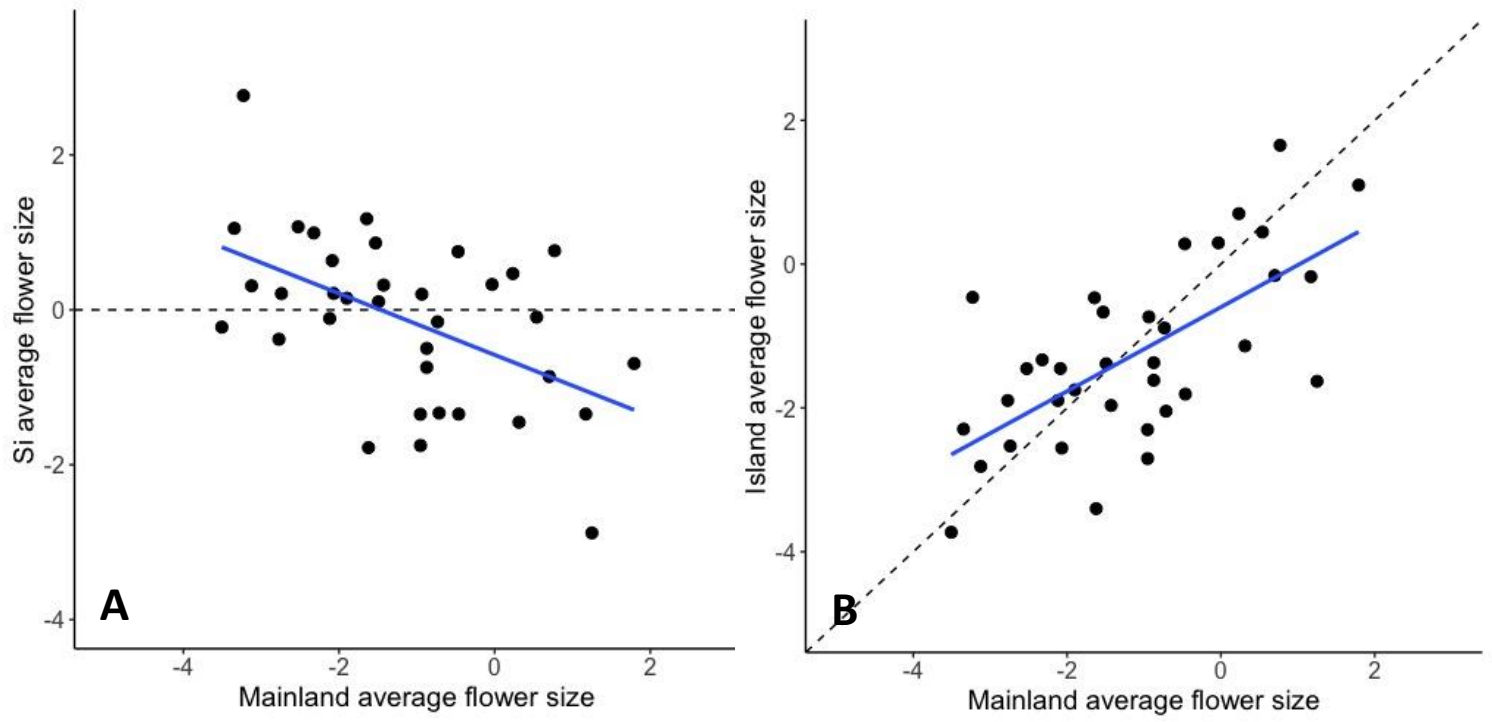

Figure 2.3 Flower area comparison of Island versus mainland. A) Comparing Si against Mainland average flower area. $R^{2}=0.26$. B) Comparing Island against Mainland average flower area. $R=0.66$. Dashed line (Line of Isometry) is the plane at which Island values equal mainland values. (Both axes are natural logged) 

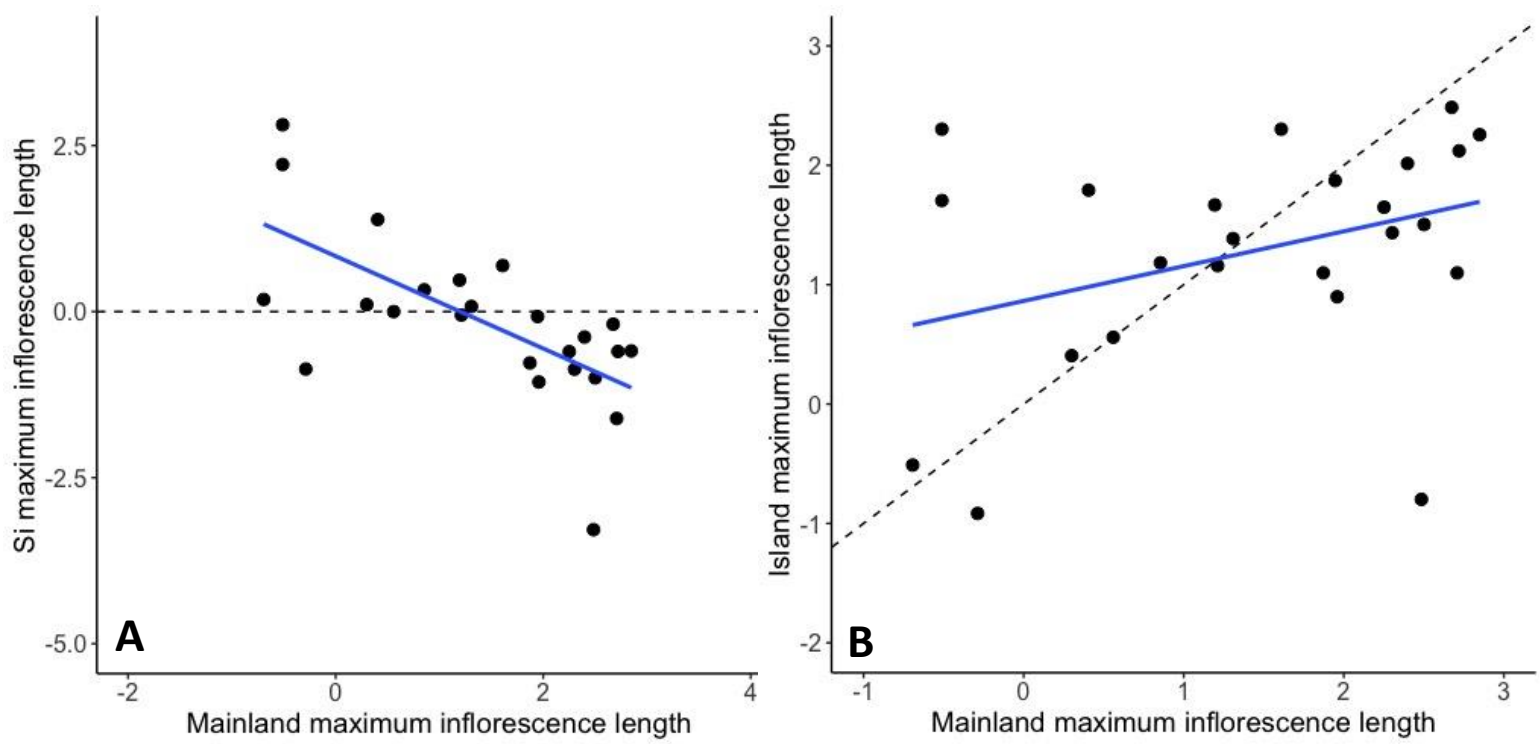

Figure 2.4 Inflorescence length comparison of Island versus mainland. A) Comparing Si against Mainland maximum inflorescence length. $R^{2}=0.44$. B) Comparing Island against Mainland maximum inflorescence length. $R=0.35$. Dashed line (Line of Isometry) is the plane at which Island values equal mainland values. (Both axes are natural logged)
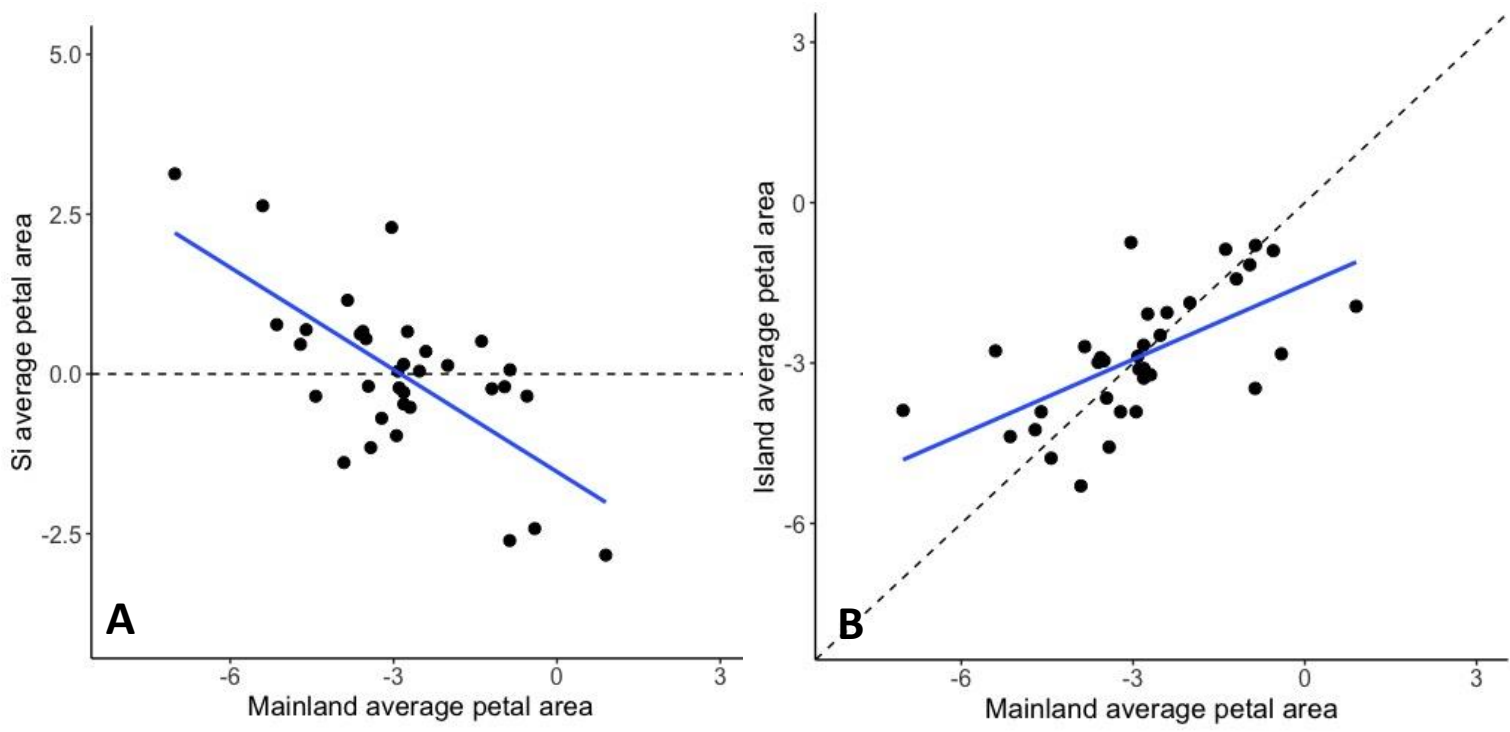

Figure 2.5 Petal area comparison of Island versus mainland. A) Comparing Si petal area against Mainland average petal area. $R^{2}=0.46$. B) Comparing Island against Mainland average petal area. $R^{2}=0.63$. Dashed line (Line of Isometry) is the plane at which Island values equal mainland values. (Both axes are natural logged) 

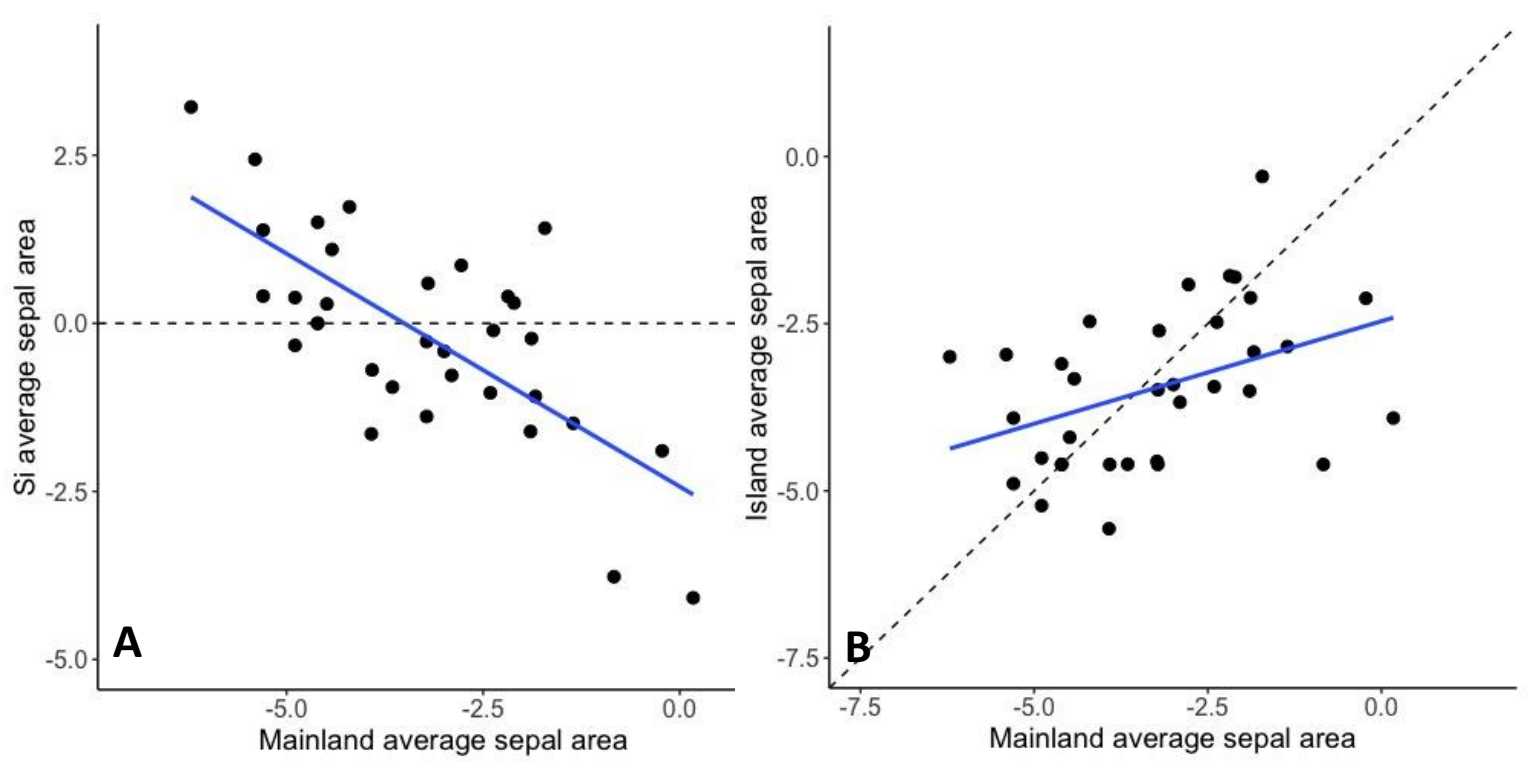

Figure 2.6 Sepal area comparison of Island versus mainland. A) Comparing Si average sepal area against Mainland average sepal area. $R^{2}=0.49$. B) Comparing Island against Mainland average sepal area. $R=0.40$. Dashed line (Line of Isometry) is the plane at which Island values equal mainland values. (Both axes are natural logged)
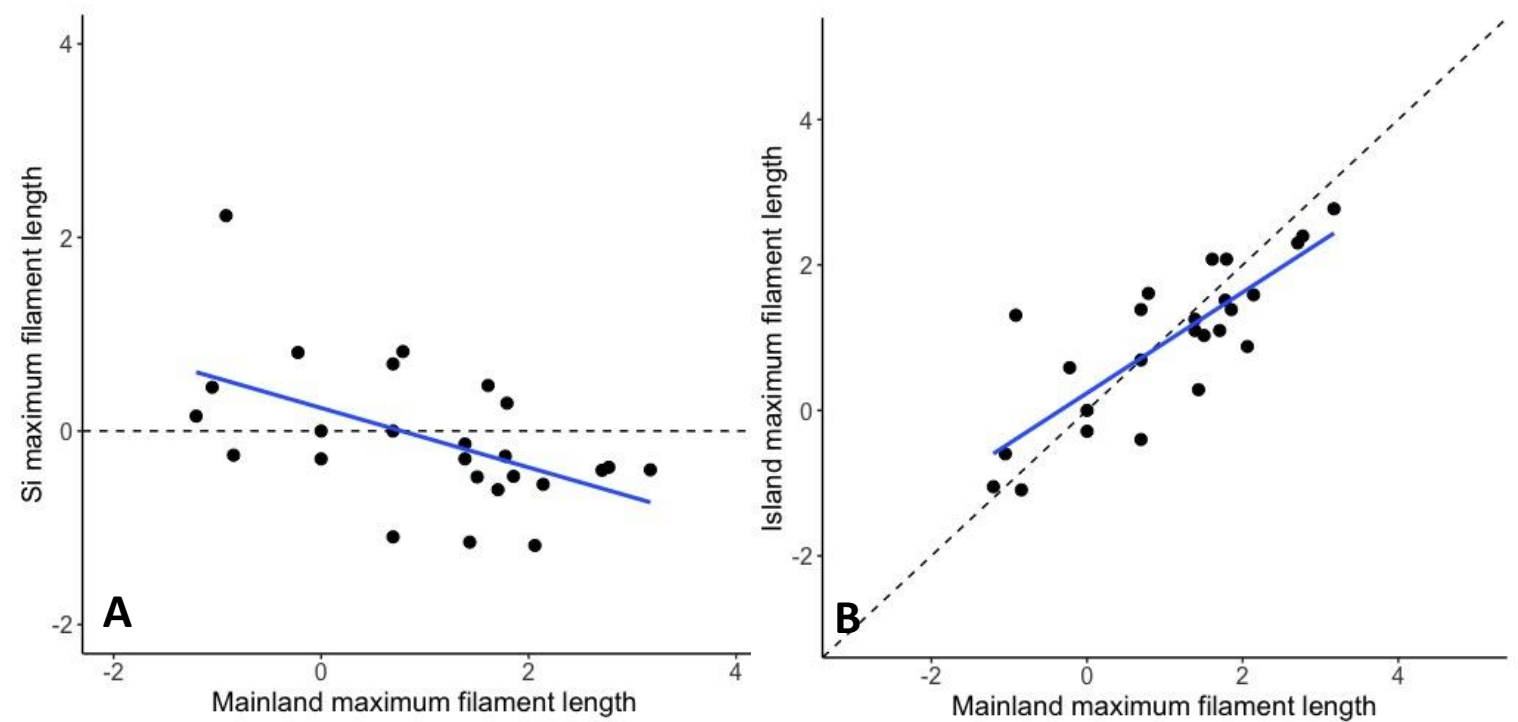

Figure 2.7 Filament length comparison of Island versus mainland. A) Comparing Si filament length against mainland maximum filament length. $R^{2}=0.27$. B) Comparing Si filament length against mainland maximum filament length. $R=0.81$. Dashed line (Line of Isometry) is the plane at which Island values equal mainland values. (Both axes are natural logged) 

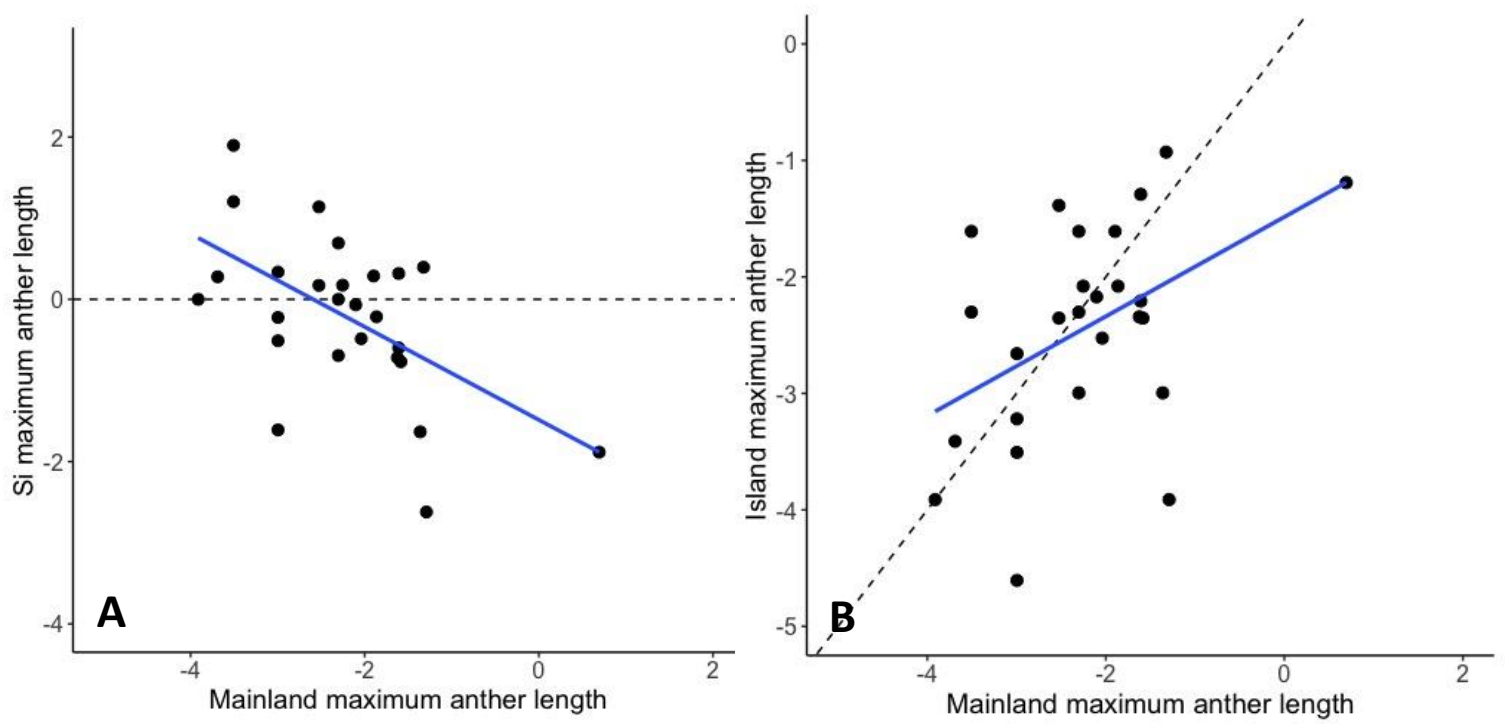

Figure 2.8 Anther length comparison of Island versus mainland. A) Comparing Si anther length against mainland maximum anther length. $R^{2}=0.31$. B) Comparing Si anther length against mainland maximum anther length. $R=0.45$. Dashed line (Line of Isometry) is the plane at which Island values equal mainland values. (Both axes are natural logged)
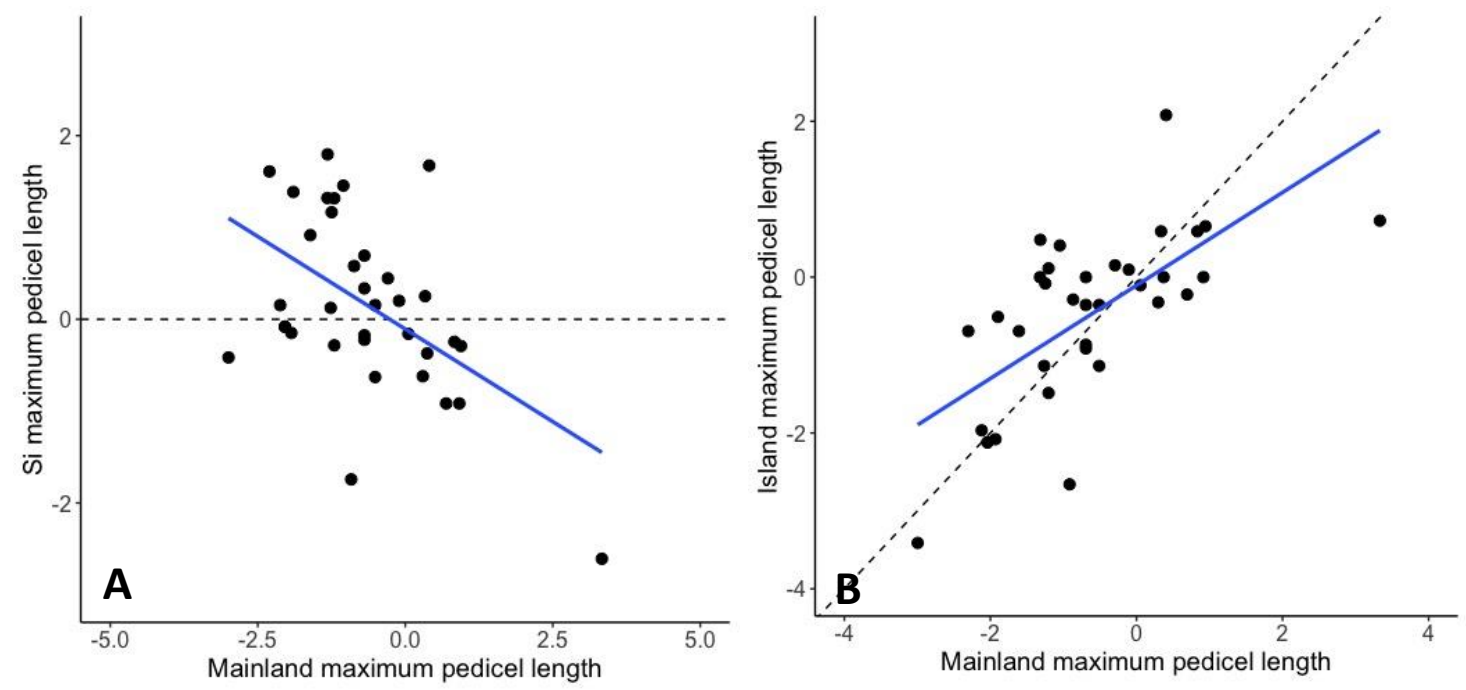

Figure 2.9 Pedicel length comparison of Island versus mainland. A) Comparing Si pedicel length against mainland maximum pedicel length. $R^{2}=0.26$. B) Comparing Si pedicel length against mainland maximum pedicel length. $R^{2}=0.66$. Dashed line (Line of Isometry) is the plane at which Island values equal mainland values. (Both axes are natural logged) 


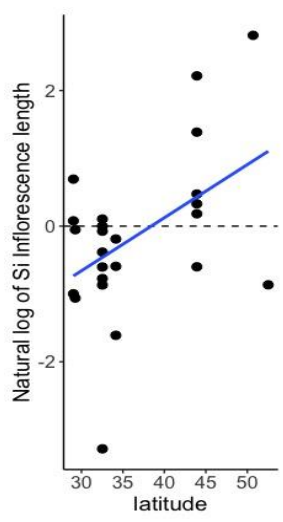

Figure 2.10 Inflorescence length compared to latitude. Measurement data is natural logged. The dashed lined represented the line of isometry, where Island values $=$ mainland values. $R^{2}=0.22, p$ value $=0.02$. Latitude is measured in 'Decimal degrees'.
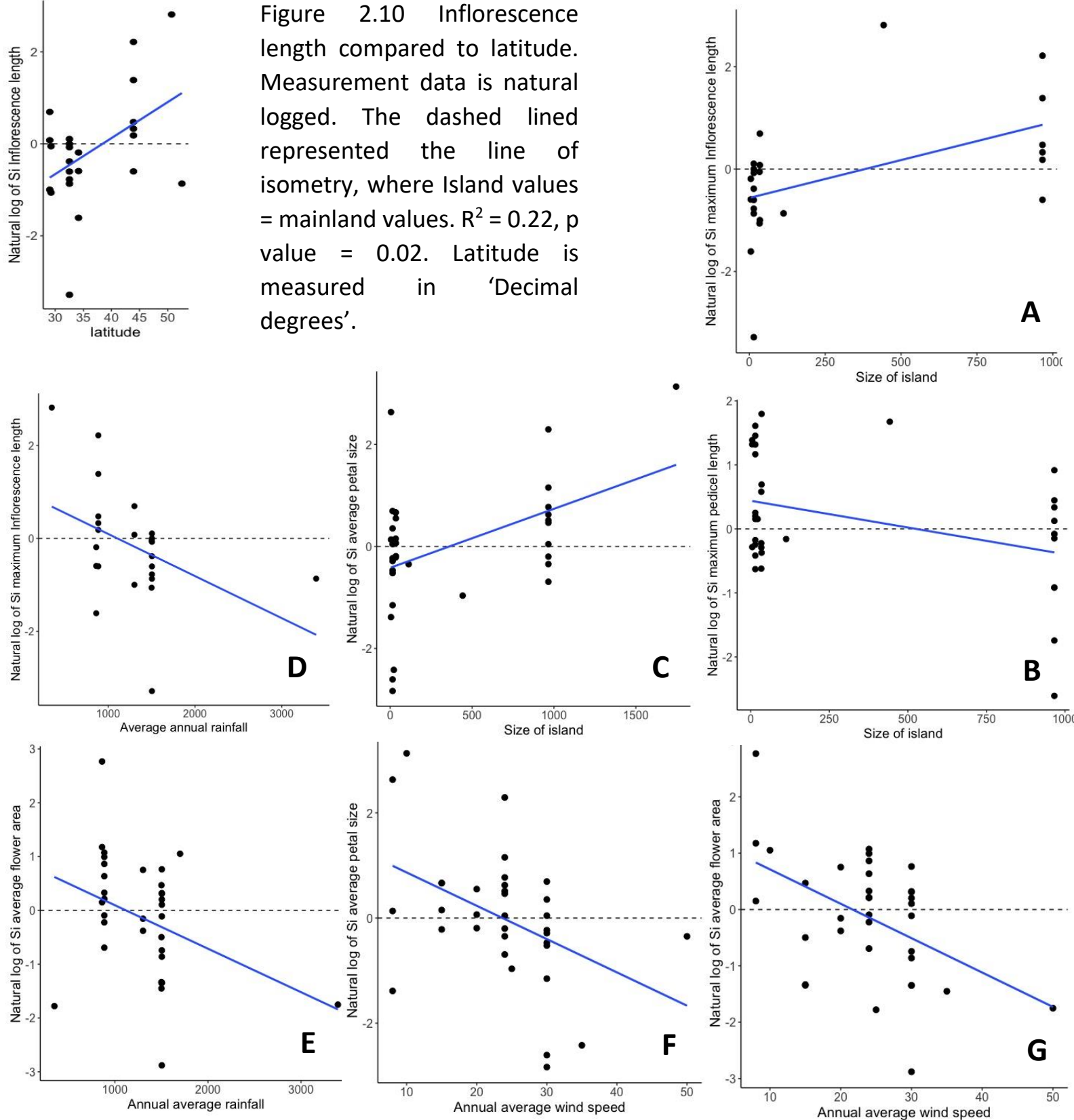

Figure 2.11 The statistical significant graphic results of Island Rule across factors for different floral traits: Size of island $(A-C)$, Average annual rainfall $(D, E)$, and Annual average wind speed $(F, G)$. All measurement data is natural logged. The dashed lined represented the line of isometry, where Island values = mainland values. See Appendix B for test statistic values. 


\section{Discussion}

The presence of the Island Rule in seven floral traits was observed (flower area, inflorescence length, petal area, sepal area, filament length, anther length and pedicel length). There was a pattern of island dwarfism (compared to large mainland counterparts) to gigantism (compared to small mainland counterparts). Evidence of insular size range reduction was clear, thereby supporting the Island Rule. Island trait size reduction occurred irrespective of latitude. Evidence for size range reduction in insular traits occurred across multiple trait analyses. This is the first empirical evidence for the pattern of size diversity reduction in floral features.

\section{Processes acting to reduce floral trait size range}

Flower size tends to vary as a function of pollinator type and size (Jordano, 1987; Herrera, 1989; Barrett, 1996; Hu et al., 2008; Futuyma, 2009). Pollinators can act as selective agents on floral traits (Inoue et al., 1996). Low numbers of large 'showy' flowers are correlated with low bee and butterfly numbers (Wallace, 1891). A small sample will never express the full variation of the mainland, due to statistical chance. Therefore, a reduction in floral size range may be explained by a reduction in the body size range of mainland pollinators to an island. This processes coined 'the Pollinator Potential Paradigm' provides a clear rational explanation, hypothesizing the link between reduced insular pollinator size and reduced insular floral size, and explaining floral size changes on islands.

Individuals migrating to an island still undergo natural selection, even before size trait differences between the mainland and the island are observable. The pattern of the Island Rule is inferred to reflect dissimilarities in selective pressures on islands (Lomolino, Sax, Riddle \& Brown, 2006). Factors influencing natural selection can be either biological or climatic in nature. Insular animal species can be impacted by resource limitation, or relaxation from predations (Palkovacs, 2003; Lomolino, 2005). Evolutionary processes that directly impact animals do not necessarily directly impact plants. However, as flower size is intrinsically linked with insular pollinator body size, so factors impacting pollinators may indirectly impact plants. With this connection, factors that currently are considered 'animal specific', may be indirectly 'plant specific' too. Features such as predation from carnivores, or social animal interactions, which have not classically be linked with plants, may in fact offer new insight into plant evolutionary pathways. 
Possibly confounding effects of trait allometry

All floral traits demonstrated similar graph morphologies as seen in Figures 2.3 to 2.9. If it is assumed that each species is responsible for a similar point in each graph morphology, then traits would appear linked. Plant features have displayed a tendency to have features that are correlated with one another (Corner, 1949; Niklas, 1994; Westoby \& Wright, 2003; Sun et al., 2006; Enquist, Tiffney \& Niklas 2007). In particular, these studies have focused on the connectedness of traits such as plant stature, twig and leaf size, and stature. Further evidence suggests that seed size is correlated with stature (Kavanagh \& Burns, 2014; Cox \& Burns, 2017). This is relevant to size changes of floral features as it raises questions for future research into the allometry of insular plant reproductive traits. Flowers are the structures that form seeds. A noticeable tendency for insular seeds to display gigantism (Kavanagh \& Burns, 2014 and Cox \& Burns, 2017), should be logically correlated to a tendency for larger floral features. Further research on the topic may explain if floral features (including additional traits such as ovary size, or number of ovules) display allometric relationships with other traits like seed size. However, studies have indicated that in some instances allometry has failed to be supported among different traits (Kavanagh \& Burns, 2014; Burns, 2016a; Cox \& Burns, 2017). Therefore while traits would be expected to demonstrate allometric correlations, this is not necessarily the case. Further research into this area will provide a better understanding of evolutionary size changes, and the intricacies of trait interaction.

The impact of additional factors

Of the seven floral traits, latitude only marginally impacts inflorescence length. This indicates that for these six remaining traits, the patterns are robust and exist irrespective of locality. While latitude seems to correlate with inflorescence length, a similar correlation exists for the island of origin. However, there was overlap between island standard error, and island groups were poorly represented, island of origin does not explain the size ratio of Inflorescence length. This indicates that the size change pattern which seems to exist for inflorescence length occurs due to a latitudinal gradient, more so than archipelago specific changes. When inflorescence length was considered against latitude, species on islands closer to Antarctica displayed bigger maximum inflorescence length, and species closer to the tropics displayed smaller maximum inflorescence length. These findings are consistent with Bergman's Rule (the animal based theory that latitude influences body size, with smaller species being found in warm tropical regions, and larger bodied species occurring in colder, polar areas (Niering, Whittaker \& Lowe, 
1963; Drezner, 2003). A previous study by Niering et al. (1963) found that Carnegiea gigantea seemed to display this "botanical Bergmann trend". However, critics of this study specify that this pattern depended more on rainfall (winter precipitation) over latitude associated temperature (Drezner, 2003). There are multiple additional factors closely correlated with latitude which may explain size variation across the landscape (Mosquin, 1971; Shahjahan et al., 1987; Fitter, Fitter, Harris \& Williamson, 1995; Yu, Luedeling \& Xu, 2010; Schleuning et al., 2012). While this study has provided evidence of a pattern, further research is required in order to better understand the processes acting to reduce island size diversity.

Of the seven floral traits, the size of the island of origin was correlated to three of the seven floral traits (maximum Inflorescence length, maximum pedicel size and average petal size). This indicates that for the remaining four traits, the patterns are robust and exist irrespective of locality. It is well known that bigger islands can support a greater abundance of species (Kohn \& Walsh, 1994). In addition, a larger island allows for species to be bigger (relative to smaller islands). A larger island (with more pollinators) may impact average petal size and maximum inflorescence length, as larger visual cues may result in higher rates of pollination. Larger visual cues may be selected by animal pollinators, as they stand out against other smaller individuals. Remarkably, the size pattern attributed to maximum pedicel length is the opposite of the other two traits mentioned above. The length of the pedicel dictates the distance at which the flower is held from the rest of the plant, and may indicate the plants preferred pollination pathway. Pedicel length may reflect instances of low pollinator frequency (such as smaller sized islands). Previous studies have found that a statistical significant difference in the length of pedicel in female compared to hermaphroditic flowers (Weller, Sakai, Culley, Campbell \& Dunbar-Wallis, 2006). A long pedicel would be advantageous for wind pollination, either through self-pollination or cross-pollination. In addition, a smaller pedicel with a larger flower, may reduce any damage to the pedicel during animal pollination compared to a large flower with a large pedicel.

The average annual wind speed was correlated to two of the seven floral traits (average petal size, and average flower size). This indicates that for the remaining five traits, the patterns exist irrespective of wind speed. Wind pollination is important in pollinator limited environments (Culley, Weller \& Sakai, 2002). Plant reliance on pollinators may decrease, as wind increases, as plants may be aided in wind-facilitated selfing, or variable outcrossing via 
wind pollination. The impact of wind on a plant can range from microscopic damage to regional-level successional change (Gardiner, Berry \& Moulia, 2016). Therefore, it is possible that the negative correlation of size of floral traits to annual average wind speed, may be attributed to the rate of physical damage. With winder places resulting in higher rates of damage, meaning smaller floral traits (such as petal size and inflorescence length) are selectively represented in future generations.

Annual average rainfall was correlated to two of the seven floral traits (maximum Inflorescence length, and average flower size). This indicates that for the remaining five traits, patterns exist irrespective of precipitation. There was no indication that the annual average temperature of an island impacted the size of endemic floral features relative to their closest mainland relative. This finding is consist with Drezner (2003), who found that size patterns of plants seems to relate more closely to rainfall than to temperature. High rainfall leads increased erosion, and nutrient loss. Flowers can be energetically expensive for plants (Vasconcelos \& Proenca, 2015). A negative correlation to high rainfall, may reflect this energetic relationship, indicating that smaller flowers and inflorescences are selected for in higher rainfall environments. Rainfall related damage to crops is increasing with climate change (Rosenzweig, Tubrello, Goldberg, Mills \& Bloomfield, 2002). Physical damage from rainfall events would be reduced for smaller flowers and inflorescences (compared to larger flowers and inflorescences). Which may explain the negative correlation between flower and inflorescence size versus annual average rainfall. It is possible that smaller flowers last longer than larger flowers, although, further research is required to prove this. Rainfall could limit insect pollinator availability, meaning that smaller flowers result in a higher chance of pollination, especially during long rainfall events.

\section{Closing remarks}

Understanding evolution is topical, as a changing environment will mean changing climatic processes. If plants do respond to climatic processes in the ways I have found, then it may be useful information for understanding how plants will respond in the future. These findings, and research in this area, may expose how plant lineages behave, and may be useful for future development in the horticulture, or agricultural trades. 


\section{Chapter 3: Vegetative features}

\section{Introduction}

There are a number of studies irrespective of the Island Rule that consider insular size changes in vegetative features. An aspect of the theory that seems to captivate naturalists and scientists alike is the 'the weeds to tree phenomenon', otherwise referred to as secondary insular woodiness or arborescence. Charles Darwin (1859) postulated that due to the competitive nature of island settings, an insular herb (when competing with herbaceous plants alone) might gain an advantage by growing taller. Further study by Carlquist 1974 suggested that secondary woodiness may be the result of relaxed herbivory (relative to the mainland). Alternative explanations for insular woodiness include adaptation for drought resistance (Lens et al. 2013).

However, size changes on islands are not solely linked to insular woodiness. Further research found evidence of insular size changes occurring in the absence of woodiness (Dawson 1988; Carlquist 1980; Burns 2016a; Cox \& Burns 2017). Specific examples include larger insular leaf size and stature (Cox and Burns 2017). In a similar fashion 'Megaherbs' (large herbaceous plants) can be repeatedly found on many of the sub-Antarctic Islands (Wagstaff, Breitwieser \& Ito, 2011). Such patterns were found to vary depending on the growth form of the species pair, with graminoids tending towards dwarfism, woody plants showing slight gigantism and herbaceous plants showing significant gigantism (Cox and Burns 2017). Meanwhile, Bowen \& Vuren (1997) found that island endemic plants displayed increased leaf size, but not increased woodiness compared to mainland plants. While a consistent pattern, it is unclear why gigantism may be advantageous to insular plants who do not exhibit woodiness (Dawson 1988).

Another common topic of insular size investigation is changes in leaf size. Tsukaya et al. (2007) found that island plants may exhibit significant variation in leaf shape. There is strong evidence for insular leaf gigantism (Cox and Burns, 2017), in particular insular populations of New Zealand's North Coast have demonstrated larger leaves than their relative mainland populations (Beever 1989; Burns et al. 2012). Morphological changes to plants may also result in dwarfism, in particular smaller leaf size is known to minimize herbivory (Hanley, Lamont, Fairbanks \& Rafferty, 2007). Insular species displaying larger leaves may reflect relaxed herbivory selection (Burns 2016a; Burns 2016b), while alternately, smaller leaves may reflect 
recent immigration events to islands (Cox and Burns, 2017). Leaf size may also reflect other climatic factors associated with island. Louw (2016) found that leaf area was larger at lower altitudes, a similar finding to Huntley (1971, as cited in Bakker et al. 1971). While Westoby \& Wright (2003) found that areas with higher rainfall tended to have larger leaves, while areas with less rainfall had smaller leaves.

In this chapter, following the unique opportunity to contribute towards a largely unsaturated field, I test for patterns of the Island Rule in vegetative features. The purpose is to better understand the applicability of the Island Rule across different plant taxa, especially as historically studies have neglected such theory application on plants. Further objectives were to understand if the presence (or absence) of a size change pattern could be attributed to latitude, or climatic, biological or geographic factors. To evaluate evolutionary insular size changes, the following predictions were tested using linear regressions and mixed models: (1) if there is a common size change trend among insular species, (2) that any pattern occurs irrespective of latitude, (3) other factors will not be statistically meaningful in understanding the Island Rule.

\section{Methods}

\section{Study site}

New Zealand was used as a central feature, and only islands within $1800 \mathrm{~km}$ of the coast were included. The islands contained in this geographical area were identified as having species that most likely originated from New Zealand. New Zealand (and the islands around it) have a long history of geological isolation. New Zealand and its islands isolated from Gondwana about 80 million years ago. Lord Howe, Norfolk and Macquarie islands are 7 million, 2.5 million and 300,000 years old respectively, having arisen through undersea volcanic activity. Terrestrial taxa arriving to islands all had to disperse overwater. However, land bridges may have connected some of the smaller islands around New Zealand and aided in species dispersal abilities (Diamond, 1984; Waters \& Craw, 2006). The islands considered for this study included; Antipodes, Auckland, Bounty, Campbell, Chatham, Kermadec, Lord Howe, Macquarie, Norfolk, Snares, Stewart and the Three Kings (see Figure 2.2). 


\section{Species Selection}

Determination of endemic Island plant species

A phylogenetic comparative method was undertaken in order to assess the evolutionary hypothesis of a reduction in insular size variation. In order to compare deep evolutionary time, extant island endemics were compared to their closest extant mainland relative. Checklists were compiled for all insular endemic plant species known to exist on the 12 Island groups. (See Table 2.1 below and appendices for lists, species pairs and references).

\section{Determination of closest mainland relative}

Closest mainland sister taxa were identified through molecular phylogenies where they were most closely related to a 'checklist' endemic species. Only information from phylogenies that gave rise to one closest mainland relative were used, creating 'species pairs', all other phylogenies were unusable (refer to Figure A1 (Appendix A) for examples of suitable and unsuitable phylogenies). Of a potential 275 endemic plant species, 145 were included in molecular phylogenies, however of that only 65 of those studies (from 9 islands) produced results that allowed them to be included in the study (refer to table 2.1). For the purposes of this study, it is assumed that the relevant phylogenies collected do not display issues of nonindependence between different species. To overcome this, further research should undertake phylogenetically independent contrast analysis.

\section{Collection of morphological measurements}

Data only included measurements from adult specimens, (i.e. mature reproductive individuals). Trait measurements primarily came from scientific field notes, field guidebooks or literature (see list of sources in Appendix A). This was appropriate for most cases. For some species relevant data was printed in non-English languages; if this was easily translatable, then this data was used. Morphological features considered for this study included vegetative features (Maximum plant stature, average leaf blade area and maximum petiole length). Further detail on each morphological feature for how it is specifically defined and measured can be found under the 'vegetative measurement' heading, Box 3.1.

Where trait measurements were not published, herbaria presses were referred to. In particular, specimens were measured at Auckland War Memorial Museum and Te Papa herbariums. In cases where access to digital herbarium specimens were required, dried measurements could be measured using the image software Image J. A minimum of five 
measurements for each morphological feature was required for each specimen that was measured from herbarium presses. Measurements came from all available structures on herbaria sheets, and as many independent individual plants as possible. There was a preference for physical measurements from herbaria specimens, rather than online (again refer to Appendix A to see which measurements these were).

Each of the trait data sets contained a mixture of herbarium measured and flora or literature derived species pairs. Species pairs themselves reflected only one measurement type. Datasets of both herbaria based and flora based measurements have been proven to not cause statistically significant issues (Kavanagh 2015; Cox \& Burns 2017). Regardless, the source of measurement origin was considered as a random factor for linear mixed models (see Appendix $B$ for source of measurement references). For some flora it is unclear if the measurements come from fresh or dried specimens, it is assumed that flora are compatible and follow similar rigorous standards in order to provide a true representation of the morphology of plants.

\section{Vegetative measurements}

Vegetative feature data was collected from floral descriptions, online and physical herbarium specimens and included three morphological traits. They were categorised into three distinct groups (1) Maximum plant stature, (2) average leaf blade area and (3) maximum petiole length. (See Appendix C for list of species included in each). They were defined and measured as seen in Box 3.1 


\section{Vegetation measurement definitions}

\section{BOX3.1}

\section{Stature}

Maximum plant stature is the total height in meters of the specimen measurement differed depending on plant types. For ferns this was measured as the length between ground and the tip of the longest frond. For orchids it was measured as the length between the base of the individual and the uppermost extension of leaves. For other plants such as herbs, shrubs or trees this was measured as the length from ground level to the highest point of the uppermost leaf. Stature Sample size was $n=54$

\section{Leaf area}

Leaf area was used as a term that included lamina, and blade measurements from angiosperms, ferns, palms and grasses. Average leaf area is equal to leaf blade length $\mathrm{x}$ leaf width. Leaf blade length is measured from the tip of the blade down to where the petiole and blade meet. Leaf blade width is defined as the widest measurement across the blade. Leaf blade Sample size was $n=56$

\section{Petiole length}

Maximum petiole length was used as a term that included petiole measurements from angiosperms and palms, as well as rachis measurements in ferns. Both the petiole and rachis are analogous structures, as they dictate the distance that the leaf blade is form the main body of the plant. Maximum petiole length is the total length of the petiole from point of attachment, to the start of the leaf blade. Petiole Sample size was $n=32$.

\section{Statistical Methodology}

The sample size of a given plant trait (e.g. leaf size) is a subset of the 65 available species depending on 1). If the species meets the given criteria for the measurement (as previously outlined and 2). If measurements for both the insular and mainland relative were obtainable. This means that the sample number of species in each analysis varies. All measurements were natural-logged before analysis (aside from latitude values - see below).

Analysis of the data generally followed procedure of Lomolino (2005). Any indication of visual outliers were tested using Cook's distance. Any point with a distance $>0.3$ from the mean was removed from the data (this only occurred for one data point in the Stature data set) Tests with 
outlier can be viewed in Appendix C. Statistical comparisons between the island and mainland groups used the Ime4, Imodel2 and car packages in the R environment (R Core Team 2013). Nine islands encompassing a 16,000 kilometre area of the South Pacific are represented across ten datasets. Each of these differently sized islands have their own unique climatic and biological factors that could all potentially influence certain morphological features in plants. Such factors were integrated in different mixed model approaches.

Morphological size divergence (Si) was expressed the trait measurement of an insular species divided by that of its genetically closest mainland relative's corresponding trait value. Lomolino (2005) outlines that this is a useful measurement for visualisation of the data for gigantism and dwarfism. This 'ratio' data was analysed through model 1 linear regression. Further, insular and mainland species traits were analysed through model 2 linear regression. This method avoids the potential repercussions of the Si ratio method, which may include "possible statistical problems and artefacts associated with regressions using ratios" (Lomolino 2005). Evidence supporting the presence of the Island Rule exists if the Model 2 regression trend for a trait results in an intercept $>0$ and a gradient $<1$.

\section{Linear Regressions}

Model 1 linear regression was undertaken on Si ratio data, with a general formula of: $\operatorname{Im}\left(y^{\sim} x\right)$ This formula is the basis for further linear mixed models to come. Here $x$ variable was always mainland values, while y value was either Island values or Si ratio values. T values, $P$ values and $R^{2}$ values were extracted using this method.

Model 2 regressions were conducted on the island vs. mainland data with a formula of: Imodel2( $\left.y^{\sim} x\right)$. This model is suitable, because island species vary as a function of mainland species (islands represent a subset of the mainland). This formula computed OLS (Ordinary Least Squares values). The results of this test gives an $\mathrm{R}$ value as well as a slope and intercept value for the trend of the data, along with the 95\% confidence intervals for these measurements. This allows the data trend to be statistically compared to the line of isometry (the line where island values = mainland values).

Testing of additional biological, climatic and geographical factors

Statistical analysis was also run to see if an island's latitude or additional factors influenced plant size variation. These factors are described in Table 2.2. In addition Chapter 2 explains how latitude 'decimal degrees' work worked out, and Table 2.3 presented these adjusted values. 


\section{Results}

Analysis of Island Rule trend in vegetative features

Analyses of vegetative measurements in vascular plants yielded results that were consistent with floral features. Regression results indicate that regardless of the models used, trends are consistently in line with the Island Rule; i.e. a graded trade from gigantism toward dwarfism as the mainland species size increased, with all 3 vegetative traits being consistent with the rule significant at the 0.05 level regardless of the statistical regression model table 3.1]. All vegetative features do not have an intercept of zero. The majority of the $95 \%$ confidence intervals for intercept do not include 0 , however 1 (petiole length) does. Of the 3 features, only 1 (petiole length) contains a negative value within the 95\% confidence interval for intercept, this may be a reflection of more instances of dwarfism or a no change in smaller species relative to the gigantism or no change in larger species

Analysis of Island Rule trend in plants across multiple factors

No correlations between any of the vegetative traits were found when compared to eight of the additional factors (latitude, island, measure, endemic, order, type, Orderz or temp). For these instances where correlation is not found to be significant, the Island Rule clearly occurs irrespective of factors. In these instances, the null hypothesis cannot be rejected, meaning that there is no indication that vegetative features are impacted by these factors (see Appendix $C$ for test statistics). There was no statistics support (at the 0.05 level) for correlation of the remaining three factors and the insular size change of either leaf area or petiole length. However, significant correlation (at the 0.05 level) was found for three factors (rainfall, wind and size) against the island ratio of maximum stature ( $p$ values of $5.35 e^{-6}, 0.0008$ and 0.02 respectively). There was a negative size correlation of stature with average annual rainfall and average annual wind speed. There was a positive correlation between the size correlation of stature and the size of the island of origin. 
Table 3.1. Specific statistical results table for each of the 3 indicator methods of statistical significance in different vegetative features.

\begin{tabular}{|c|c|c|c|c|c|c|c|c|}
\hline & & & & Model 1 & Model 2 & & & \\
\hline & t value & $p$ value & Slope & $\begin{array}{l}\text { Slope } 95 \% \\
\text { confidence } \\
\text { level }\end{array}$ & t value & $p$ value & Slope & $\begin{array}{l}\text { Slope } 95 \% \\
\text { confidence } \\
\text { level }\end{array}$ \\
\hline $\begin{array}{l}\text { Maximum } \\
\text { stature }\end{array}$ & -4.52 & $3.70 \mathrm{e}^{-5 *}$ & -0.24 & -0.35 to -0.12 & 12.48 & $2.01 e^{-17 *}$ & 0.73 & 0.62 to 0.85 \\
\hline Leaf area & -4.34 & $6.60 \mathrm{e}^{-5 *}$ & -0.35 & -0.52 to -0.19 & 7.84 & $7.84 \mathrm{e}^{-11 *}$ & 0.76 & 0.65 to 0.88 \\
\hline $\begin{array}{l}\text { Petiole } \\
\text { length }\end{array}$ & -3.17 & $3.30 \mathrm{e}^{-3 *}$ & -0.33 & -0.54 to -0.12 & 6.43 & $2.4 \mathrm{e}^{-7 *}$ & 0.67 & 0.46 to 0.88 \\
\hline
\end{tabular}
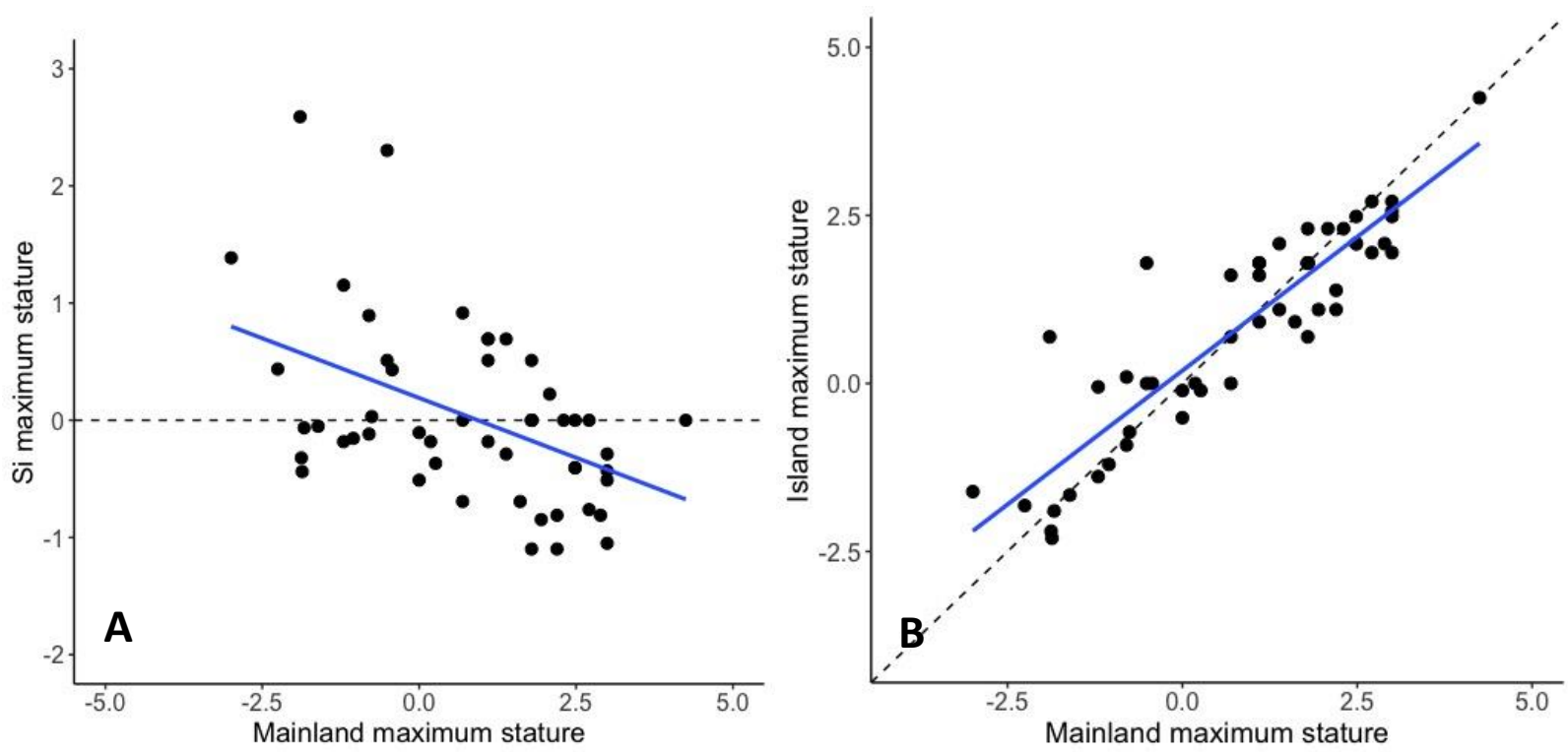

Figure 3.1 Maximum stature length comparison of Island versus mainland. A) Comparing Si against Mainland maximum stature. $R^{2}=0.29$. B) Comparing Island against Mainland maximum stature. $R=0.87$. Dashed line (Line of Isometry) is the plane at which island values equal mainland values. (Both axes are natural logged) 

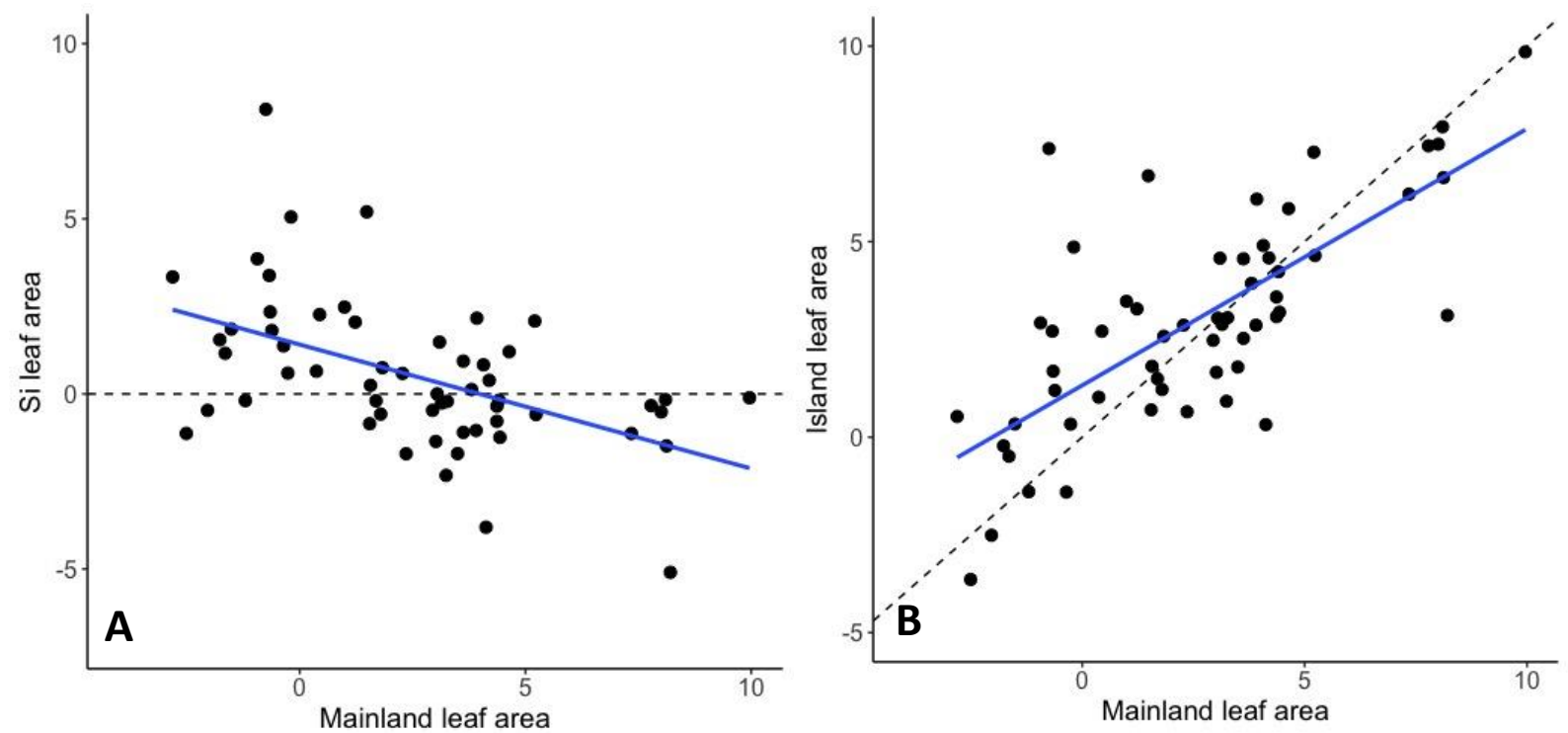

Figure 3.2 Leaf area comparison of Island versus mainland. A) Comparing Si against Mainland average leaf area. $R^{2}=0.25$. B) Comparing Island against Mainland average leaf area. $R=0.73$. Dashed line (Line of Isometry) is the plane at which island values equal mainland values. (Both axes are natural logged)
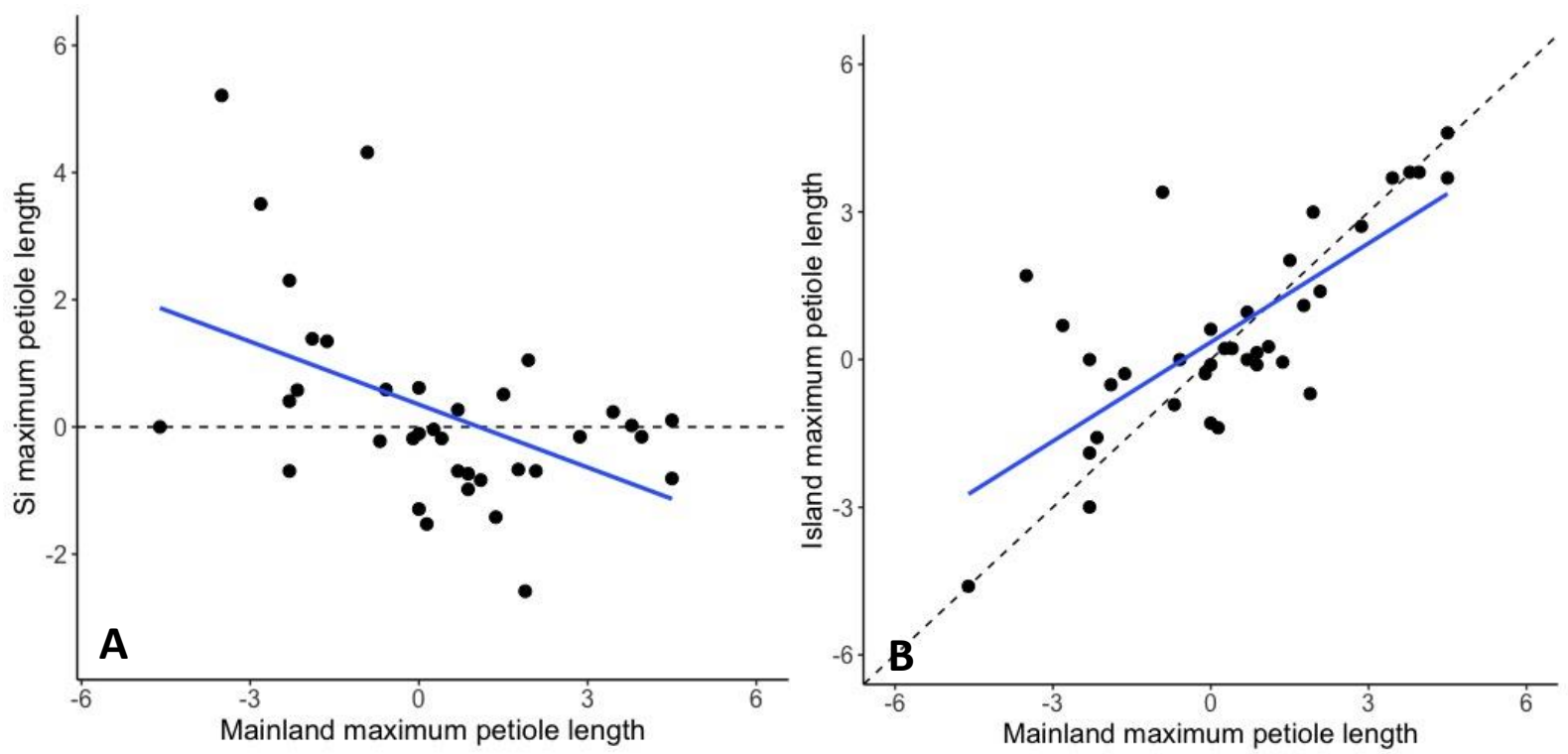

Figure 3.3 Petiole length comparison of Island versus mainland. A) Comparing Si against Mainland maximum petiole length. $R^{2}=0.23$. B) Comparing Island against mainland maximum petiole length. $R=0.74$. Dashed line (Line of Isometry) is the plane at which island values equal mainland values. (Both axes are natural logged) 

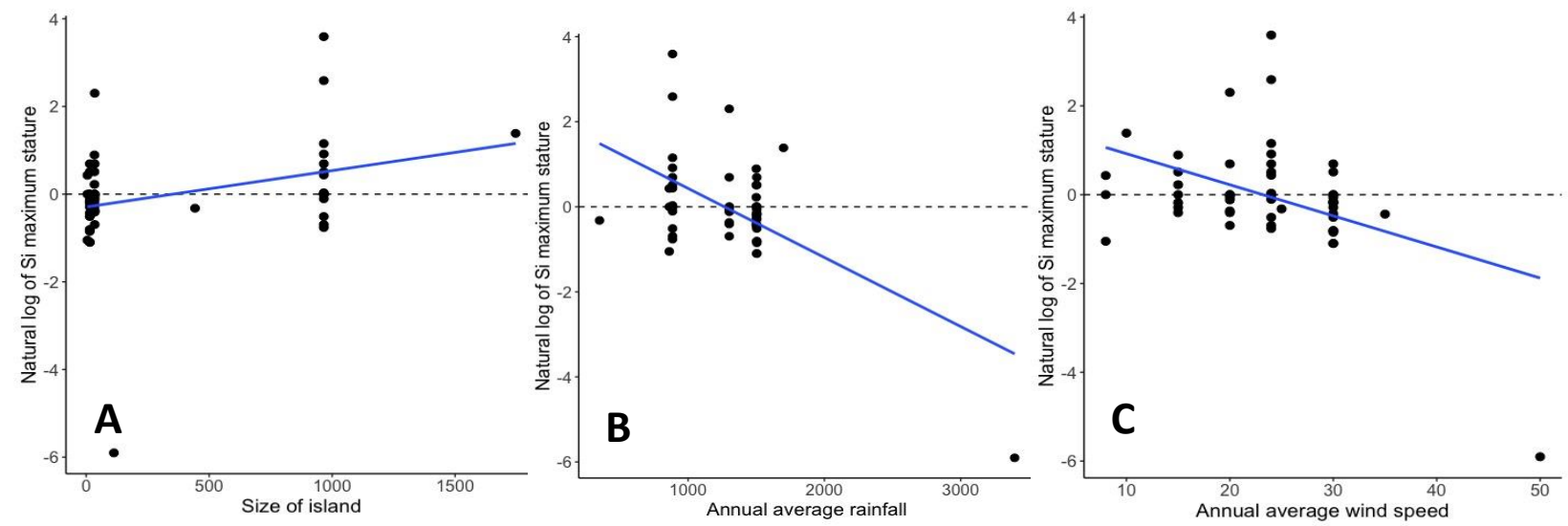

Figure 3.4 The statistical significant graphic results of stature against different factors: Size of island (A), Average annual rainfall (B), and Annual average wind speed (C). All measurement data is natural logged. The dashed lined represented the line of isometry, where Island values = mainland values. See Appendix C for test statistic values.

\section{Discussion}

My findings investigated the presence of the Island Rule in three vegetative traits (stature, leaf area and petiole length). There was a pattern of dwarfism (in large mainland counterparts) to gigantism (in small mainland counterparts). Evidence of insular size range reduction was clear, thereby supporting the Island Rule. The range of Island trait size reduced across multiple traits, irrespective of latitude.

Processes acting to reduce vegetative trait size range

Islands contain less species than the mainland, resulting in overall less diversity relative to the mainland (Olesen \& Jordano 2002; Bellemain \& Ricklefs 2008). The 'shift' of island species to display a reduced size range can be viewed as a return to a median or an optimal functional zone (Raia \& Meiri 2011; Brown, Marquet \& Taper, 1993; Damuth 1993). Island weather differs significantly from continents in that continents exhibit more stable climates; i.e. less variation (Boomert \& Bright, 2007). Variation in insular climatic factors, could provide a significant selective force for evolution of traits (Bond \& Midgley 2001). This stability fosters wider specialisation and diversity in plants, while in contrast the turbulent conditions found on islands favours generalists.

Vulnerable plants displaying significant variation in fragile environments are better able to persist due to stable environmental conditions (Bond \& Midgley 2001). Strong selective circumstances force species into extinction, or to undergo evolutionary selection for beneficial 
traits (MacArthur \& Wilson, 2001). Therefore, a mainland progenitor species displaying notable extreme variation, would be required to demonstrate a trait 'shift' in order for the lineage to persist on an island. Therefore, island plants may undergo changes towards an optimal functional zone due to less pronounced mainland selection pressures. Common occurrences of size range reduction indicates that optimal functional zones seem to occur across many vegetative traits.

Possible confounding effects of trait allometry

Plant features have been proven to be intrinsically linked (Niklas 1994; Corner 1949; Enquist et al. 2007; Westoby \& Wright, 2003; Sun, Jin \& Shi, 2006). Through the development constraint hypothesis (Harvey \& Pagel 1991), one feature can only demonstrate change in morphology within the constraints of supporting traits. All three of the vegetative traits displayed similar results. The pattern of the data was similar between traits (Figures 3.1 to 3.3). While my results did not follow trends within a species, similar patterns between traits may indicate that they are intrinsically linked. Corner (1949) demonstrated previously that seed size is correlated with traits such as stem size and plant height. Kavanagh \& Burns (2015) and Cox \& Burns (2017) also found evidence that insular seed size tended to display gigantism, and correlate with plant stature. However, the same studies found that not all traits correlate, and that some, such as leaf size, display size independently of other traits. If traits are linked, it will be difficult to disentangle whether evolutionary processes act on one trait at one time, all traits at the same time, or only some traits at any given time. Finding answers to such questions will improve our understanding of evolutionary size changes in vegetative traits, especially for terrestrial plant species.

The Possible confounding effects of location

Concern has been raised, especially for animal studies, that human propensity to move species and cause localised extinctions may 'blur' the true extent of insular patterns of evolution (Faurby \& Svenning, 2016). Plants are specifically collected and moved outside of their natural geographical location by botanists, and garden enthusiasts. Generally, plant origin is more confidently located than animal origins, as plants outside of natural geographic locations often breed more poorly, and are usually geographically bound (Nathan, 2006). Plant dispersal via anthropogenic means is also a more recent occurrence, dependant in part, on technological advances allowing for successful transportation (Nathan, 2006). Therefore, the concern of 
historic anthropogenic interference in species dispersal, is probably more pronounced in animal taxa, compared to plant taxa. Further study could aim to understand if factors associated with anthropogenic interference, or taxonomic propensity pose an impact on observing evolutionary size changes in plant.

The impact of latitude and island factors

A plant's stature is arguably one of its most important features, as the height of a plant can dictate its success to be pollinated, withstand meteorological events, or accomplish photosynthesis (Anten, 2004). Increasingly, studies are finding that latitude is often not the factor responsible for driving evolutionary change (Schleuning et al. 2012; Fitter et al. 1995; Mosquin 1971; Yu, Luedeling, Xu 2010; Shahjahan, Duve \& Bonman 1987). Abiotic factors (in particular rainfall) have been reported as accountable for 'latitudinal trends' (Louw, 2016). Drezner (2003) found that different climatic factors across latitude (such as rainfall) were better explanations for differences in stature of insular plant species compared to other factors, such as temperature. The results from my research support this literature. High rainfall may lead increased erosion, and nutrient loss. A negative correlation between annual average rainfall and insular plant maximum stature may reflect this relationship, and indicates that smaller species are selected for in higher rainfall environments. In addition, Rosenzweig et al., (2002) found that rainfall related damage to crops is increasing with climate change. Physical damage from rainfall events would be reduced for plants with smaller stature (compared to larger stature plants). Which may explain the negative correlation between plant stature size ratios versus annual average rainfall.

It is well known that bigger islands can support a greater abundance of species (Kohn \& Walsh, 1994; Panitsa, Tzanoudakis, Triantis \& Sfenthourakis, 2006). In addition, a larger island would allow for species to be bigger (relative to smaller islands). The finding that insular plant patterns are positively correlated with bigger island size, may therefore reflect high levels of intra-specific competition environments.

Gardiner et al. (2016) discuss how the impact of wind on a plant can range from microscopic damage to regional-level successional change. Therefore, it is possible that the negative correlation of plant stature to annual average wind speed, may be attributed to the rate of physical damage. With winder places resulting in higher rates of damage, meaning smaller plants are selectively represented in future generations. 
It is possible that the correlations seen for annual average wind speed, and size of the island of origin are related. Because small islands are more exposed (Panitsa et al., 2006), they would tend to be winder than bigger islands. This means it is difficult to say if the size of the island, or the level of average wind exposure, or some combination of the two factors best explains size patterns seen for insular plant stature. Further research will be required to disentangle this factors.

\section{Closing remarks}

Vegetative traits exhibited patterns consistent with the island rule across multiple statistical tests and factors. No additional factors correlated with insular size changes patterns seen for leaf area or petiole length. The results of this study support previous research, which has considered island size change patterns on islands, particularly around the patterns and explanations for patterns seen with insular maximum stature. The Island Rule is presented here as a robust theorem for plant features. Such evidence provides insight into the further application of the rule, and a better understanding of the extent to which it can be applied across multiple geographical areas. 


\section{Chapter 4: General Discussion}

\section{Insular size changes in plants}

As part of this thesis, investigation occurred to understand insular plant size variation in the South Pacific. The findings of Chapter 2 (floral features) are entirely novel, and provide consistent evidence of reduced island size diversity. This pattern was observed regardless of the statistical models used. Secondly, vegetative traits (Chapter 3) also demonstrated a tendency for reduced size variation, thereby providing evidence for the Island Rule. These findings were consistent with recent studies indicating that insular species display significant morphological differences relative to their mainland counterparts (Kavanagh \& Burns 2015; Cox and Burns 2017).

\section{Processes and mechanisms of insular plant size change}

Flowers are arguably one of the most important features for a plant. Without pollination, subsequent fertilisation and dispersal of genes cannot occur (for sexual flowers relying on sexual reproduction). In Chapter 2, the first empirical testing demonstrated a reduction in the size range of island plant floral features. Additionally, for the first time, academic claims that latitude seemed to have an effect on flower size were investigated (Darwin 1835; Wallace 1832 and Carlquist 1974). According to my results there is strong evidence that reduction of floral size range on islands, occurs irrespective of latitude.

The Pollinator Potential Paradigm provided a clear rationale why floral features may reflect evidence for size range reduction. Flowers co-evolve with pollinators. For example, there are cases where flowers display incredibly complex morphology, and in a like-wise manner the pollinator does too (Kritsky 1991). Modelling of mainland compared to island body size range (through the Pollinator Potential Paradigm) indicates that flower size may be driven by stochastic chance of pollinator dispersal. Reduced body size range of insular pollinators (compared to the mainland), effectively seems to account for why islands have a reduced floral size range compared to the mainland. Changes in morphology are known to be driven by both biotic and abiotic factors. Insular evolution therefore not only relies on the conditions of the Island, but also the composition of other species on the island as well, in particular species that 
provide a supporting ecosystem service. It may be that other island bound species play a larger role in dictating the evolutionary trajectory of a specific species than currently acknowledged.

Evolutionary trends in vegetative features, seem better understood than floral features. For Chapter 3, evidence of the Island Rule was found across all vegetative traits. Stature changes (generally associated with insular woodiness) have been studied extensively (Darwin 1835; Carlquist 1974; Hochberg 1980; Beever 1989; Givnish 1998; Hanley et al. 2007; Burns et al. 2012; Wagstaff et al. 2011; Burns 2014; Kavanagh 2015). Compared to these papers, my results differed, in that clear evidence for support of the island rule was demonstrated. It seems that reduced size range in insular vegetative traits are best explained as optimal functional zone 'shifts' (Brown, Marquet \& Taper, 1993; Damuth 1993; Raia, Meiri 2011). That is to say, if an island's small species increase in size and big species decrease in size, overall the total size range of this island 'moves away' from extreme values. Therefore, as variation in size decreases, the values themselves become closer towards a common average. Island variation is usually contained within the variation limits of the mainland, thereby being an optimisation zone. Previous to this study reporting on insular size changes were generally directional (either trending toward gigantism or dwarfism). The findings of this thesis demonstrated the first empirical testing of a reduction of size variation in endemic island plant petioles (compared to petioles of their closest mainland relative). In addition, other vegetative traits displayed the expected trend of the Island Rule. Such information demonstrates the persistence of this pattern across multiple vegetative traits.

\section{Possible confounding effects of trait allometry}

The reoccurring theme that plant features all display a similar pattern of a graded trend from dwarfism to gigantism could be explained by Havey \& Pagel's 1991 Theory of Development Constraint. One trait can only demonstrate change to the constraint of supporting traits. This could mean for example; potential for leaf size to increase is dependent on the petiole, which in turn is dependent on the plant's structure. Plant features have displayed a tendency to have features that are correlated with one another (Corner 1949; Niklas 1994; Westoby \& Wright, 2003; Enquist et al. 2007; Sun, Jin \& Shi, 2006). The patterns exhibited by plant features considered in this thesis may reflect the relatedness of features within a species. However, studies have shown that some insular plants do not support the Development 
Constraint Theory. For these examples traits demonstrate change independent of other traits (Kavanagh \& Burns 2014; Cox \& Burns 2017). Further research is required in order to better understand the processes and tendencies of evolutionary insular size change.

\section{The effect of latitude and archipelago}

Empirical evidence suggested that latitude had minimal impact on the size of insular traits. Of the ten traits considered in this thesis (flower area, inflorescence length, petal area, sepal area, filament length, anther length, pedicel length, stature, leaf area and petiole length) only one feature indicated that latitude may play a role in insular sizing (maximum inflorescence length). Such findings are in contrast with previous studies such as Niering et al. (1963) who demonstrated that Carnegiea gigantea seemed to display a "botanical Bergmann trend", where differences were attributable across a latitudinal gradient. It should be noted that latitude gradients differ from one another especially in regards to area. This means that true comparisons of latitude variation are not necessarily comparable. My findings support previous studies which failed to find support for common trends along latitudinal gradients (Schleuning et al. 2012; Fitter et al. 1995; Mosquin 1971; Yu, Luedeling, Xu 2010; Shahjahan, Duve \& Bonman 1987). Instead alternative abiotic forces, such as altitude may be a better explanation for plant size variation (Louw, 2016). This demonstrates that the Island Rule is a robust concept that occurs irrespective of the geographical location or archipelago.

\section{The effect of climate and Island size}

Three additional factors were found to show some level of impact on floral and vegetative features, these were annual average wind speed, average annual rainfall, and the size of the island of origin. My findings support previous studies that find rainfall and stature is correlated (Givnish, Wong, Stuart-Williams, Holloway-Phillips \& Farquhar, 2014). However no previous study seems to have previously researched the correlation between annual average rainfall and inflorescence length or flower size.

The findings that species display larger insular size on larger islands, is a basic tenant of biology, big species can only survive in large areas with access to resources. Therefore it is not surprising to find that the size of the island of origin is positively correlated to stature, and inflorescence length. Remarkably the finding that pedicel length is negatively correlated to island size indicates that there is a selection process occurring that demands further study. 
My findings of annual average wind speed, seem to be novel. While there does not seem to be research investigating the impact that wind speed can have on insular plant size, there is evidence that wind can have a serious impact on plants (Gardiner et al., 2016). This is yet another topic uncovered by this research that requires further investigation.

It seems likely that there are correlations between different factors. The size of an island, can reflect how exposed it is, and therefore how windy (Panitsa et al., 2006). Further research in the nature of the interactions between different factors and the true impact they have on plant features will be required to better understand the evolution of endemic insular plant species.

\section{Critical analysis and potential limitations of the methodology}

There is no perfect way in which to conduct science, and all methods are inherently biased, and assumptions should be acknowledged and if possible, controlled so that confidence can be placed in a study (Marczyk, DeMatteo \& Festinger, 2005). The use of both herbarium specimen literature and measurements could have introduced bias into the research. However, this was controlled for by testing if the origin of measurement impacted the results. There was no statistical evidence that this occurred, in addition findings from Cox and Burns (2017) indicate that this data treatment is robust, and suitable. In this thesis the main assumptions come from phylogenies from which this whole research project has been underpinned by. Caution over the use of phylogenetic methods is frequently cited as a cause for concern (Huelsenbeck \& Kirkpatrick, 1996). The identification of species pairs has been exclusively based on the topological congruence of phylogenetic reconstructions. This means that even though inferred relationships have been created through the use of bootstrapping and baseian support it might not truly reflect the evolutionary history of species seen on an island. Populations are dynamic, and can change dramatically over very short time periods. The transient nature of organism means that current distributions do not necessarily represent historic distributions (Hallström \& Janke, 2010). From the phylogenies it is impossible to know (without extensive research) if there was limited sampling of species, or if the creation of the phylogeny was impacted by extinction events. The nature of organisms is also difficult to represent in a phylogeny, in that near-shore island floras may be the result of multiple colonisation events within a given lineage. Such suspicions could only be known from repeating a comprehensive replication of both island and mainland populations, which even then may 
result in an inconclusive outcome. Finally, this methodology assumes that the DNA recovered from cells is comparable, in that it has been correctly sampled, from the correct species,

without contamination, and that sequences have been lodged without glitches or misslabelling, and that they were included as art of the phylogenetic work.

\section{Conclusions and Future directions}

While the Island Rule has consistently framed thinking for insular animal species, it has rarely been utilized as a framework for insular plant studies. In this thesis, not only has novel investigation occurring through the first empirical study of reduced insular floral size diversity, but I have also presented a holistic understanding of support for the Island Rule across vegetative features. It is clear that such patterns tend to exist irrespective of the plant trait. Further research is required to better understand why this might be the case.

Going forward this research sets the standard for future research in the area, and also provides a platform from which a greater understanding on insular species can come from. Future research might consider morphology changes at individual population levels. Do certain tendencies to display dwarfism of one trait result in other traits 'following suit'? Is there an interaction between some geographic factors and biological factors that influence certain traits in light of the Island Rule? Subsequent investigation following the basis that this thesis has set out, will continue to unravel the intricacies of insular plant evolution. 


\section{References}

Albach, D. C., \& Greilhuber, J. (2004). Genome size variation and evolution in Veronica. Annals of Botany, 94(6), 897-911.

Allan, H. H. (1961). Flora of New Zealand. Volume I. Flora of New Zealand. Volume I., (8 x 5 1/2).

Anten, N. P. (2004). Optimal photosynthetic characteristics of individual plants in vegetation stands and implications for species coexistence. Annals of Botany, 95(3), 495-506.

Augspurger, C. K. (1986). Morphology and dispersal potential of wind-dispersed diaspores of neotropical trees. American journal of Botany, 73(3), 353-363.

Australia. Bureau of Flora, \& Australian Biological Resources Study. (1981). Flora of Australia (Vol. 49). CSIRO, Melbourne.

Australia. Bureau of Flora, \& Australian Biological Resources Study. (1981). Flora of Australia (Vol. 50). CSIRO, Melbourne.

Australian Tropical Rainforest Orchids (2010). Orchids of the Australian Tropical Rainforest. Retrieved from: http://keys.trin.org.au/key-server/data/08090a09-0d0e-410b-860c020705070e0e/media/Html/index.htm.

Australian tropical Rainforest Plants (2010). Australian tropical Rainforest Plants. Ged Retrieved from: $\quad$ http://keys.trin.org.au:8080/key-server/data/0e0f0504-0103-430d-8004060d07080d04/media/Html/index.html.

Baba, Y. (2013). Evolution, systematics and taxonomy of Elaeocarpus (Elaeocarpaceae) in Australasia (Doctoral dissertation, James Cook University).

Bakker E. M., Winterbottom J. M., \& Dyer R. A. (1971)., Marion and Prince Edward Islands. AA Balkema, Cape Town.

Barrett, S. (1996). Floral biology: studies on floral evolution in animal-pollinated plants. Springer Science \& Business Media.

Beever, R. E. (1986). Large-leaved plants of the northern offshore islands, New Zealand. The offshore islands of northern New Zealand. New Zealand Department of Lands and Survey Information Series, 16, 51-61.

Bellemain, E., \& Ricklefs, R. E. (2008). Are islands the end of the colonization road?. Trends in Ecology \& Evolution, 23(8), 461-468.

Benkman, C. W. (1995). Wind dispersal capacity of pine seeds and the evolution of different seed dispersal modes in pines. Oikos, 73(2), 221-224.

Bernardello, G., Anderson, G. J., Stuessy, T. F., \& Crawford, D. J. (2001). A survey of floral traits, breeding systems, floral visitors, and pollination systems of the angiosperms of the Juan Fernández Islands (Chile). The Botanical Review, 67(3), 255-308.

Blackburn, T. M., Gaston, K. J., \& Loder, N. (1999). Geographic gradients in body size: a clarification of Bergmann's rule. Diversity and distributions, 5(4), 165-174. 
Böhle, U. R., Hilger, H. H., \& Martin, W. F. (1996). Island colonization and evolution of the insular woody habit in Echium L.(Boraginaceae). Proceedings of the National Academy of Sciences, 93(21), 11740-11745.

Bond, W. J., \& Midgley, J. J. (2001). Ecology of sprouting in woody plants: the persistence niche. Trends in ecology \& evolution, 16(1), 45-51.

Boomert, A., \& Bright, A. J. (2007). Island archaeology: in search of a new horizon. Island Studies Journal, 2(1), 3-26.

Bossdorf, O., Auge, H., Lafuma, L., Rogers, W. E., Siemann, E., \& Prati, D. (2005). Phenotypic and genetic differentiation between native and introduced plant populations. Oecologia, 144(1), 1-11.

Bowen, L., \& Vuren, D. V. (1997). Insular endemic plants lack defenses against herbivores. Conservation Biology, 11(5), 1249-1254.

Brown, J. H., Marquet, P. A., \& Taper, M. L. (1993). Evolution of body size: consequences of an energetic definition of fitness. The American Naturalist, 142(4), 573-584.

Brown, G. K., Udovicic, F., \& Ladiges, P. Y. (2001). Molecular phylogeny and biogeography of Melaleuca, Callistemon and related genera (Myrtaceae). Australian Systematic Botany, 14(4), 565-585.

Browne, J. (2010). Charles Darwin: Voyaging: Volume 1 of a biography. Random House, Wellington.

Brownsey, P. J., \& Chinnock, R. J. (1987). A taxonomic revision of the Australian species of Hypolepis. Journal of the Adelaide Botanic Garden, 1-30.

Bunce, M., Szulkin, M., Lerner, H. R., Barnes, I., Shapiro, B., Cooper, A., \& Holdaway, R. N. (2005). Ancient DNA provides new insights into the evolutionary history of New Zealand's extinct giant eagle. PLoSbiology, 3(1), e9.

Burke, J. M., Bayly, M. J., Adams, P. B., \& Ladiges, P. Y. (2008). Molecular phylogenetic analysis of Dendrobium (Orchidaceae), with emphasis on the Australian section Dendrocoryne, and implications for generic classification. Australian Systematic Botany, 21(1), 1-14.

Burns, K. (2005). A multi-scale test for dispersal filters in an island plant community. Ecography, 28(4), 552-560.

Burns, K. C. (2016a). Size changes in island plants: independent trait evolution in Alyxia ruscifolia (Apocynaceae) on Lord Howe Island. Biological Journal of the Linnean Society, 119(4), 847-855.

Burns, K. C. (2016b). Spinescence in the New Zealand flora: parallels with Australia. New Zealand Journal of Botany, 54(2), 273-289.

Burns, K. C., Herold, N., \& Wallace, B. (2012). Evolutionary size changes in plants of the southwest Pacific. Global Ecology and Biogeography, 21(8), 819-828.

Carlquist, S. (1974). Island biology. Columbia University Press: New York \& London. 
Carlquist, S. (1980). Hawaii: a natural history. Geology, climate, native flora and fauna above the shoreline (Vol. 6). Honolulu: SB Printers, Inc. for Pacific Tropical Botanical Garden (xii), 468p.-illus., col. illus., maps. En Icones, Maps. Geog.

Carrodus, S. K. (2009). Identification and the role of hybridisation in New Zealand Pittosporum (Doctoral dissertation, University of Waikato).

Case, T. J. (1978). A general explanation for insular body size trends in terrestrial vertebrates. Ecology,59(1), 1-18.

Chapin III, F. S., Autumn, K., \& Pugnaire, F. (1993). Evolution of suites of traits in response to environmental stress. The American Naturalist, 142, S78-S92.

Chao, Y. S., Rouhan, G., Amoroso, V. B., \& Chiou, W. L. (2014). Molecular phylogeny and biogeography of the fern genus Pteris (Pteridaceae). Annals of botany, 114(1), 109-124.

Clout, M. N., \& Craig, J. L. (1995). The conservation of critically endangered flightless birds in New Zealand. Ibis, 137, S181-S190.

Corner, E. J. H. (1949). The durian theory or the origin of the modern tree. Annals of Botany, 13(52), 367-414.

Costa, L. D. F. D., \& Cesar Jr, R. M. (2000). Shape analysis and classification: theory and practice. CRC Press, Inc..

Cox, B. T. M., \& Burns, K. C. (2017). Convergent evolution of gigantism in the flora of an isolated archipelago. Evolutionary Ecology, 31(5), 741-752.

Crawford, D. J., \& Archibald, J. K. (2017). Island floras as model systems for studies of plant speciation: Prospects and challenges. Journal of Systematics and Evolution, 55(1), 1-15.

Culley, T. M., Weller, S. G., \& Sakai, A. K. (2002). The evolution of wind pollination in angiosperms. Trends in Ecology \& Evolution, 17(8), 361-369.

Damuth, J. (1993). Cope's rule, the island rule and the scaling of mammalian population density. Nature, 365(6448), 748.

Dockrill, A. W. (1967). Australian Sarcanthinae: A Review of the Subtrive Sarcanthinae (Orchidaceae) in Australia and New Zealand. Australian Native Orchid Society.

Darwin, C. (1835). The Works of Charles Darwin, Volume 1: Diary of the Voyage of the HMS Beagle (Vol. 1). NYU Press.

Darwin, C. (1859). On the origin of species by means of natural selection. J Murray, London

Daugherty, C. H., Gibbs, G. W., \& Hitchmough, R. A. (1993). Mega-island or micro-continent? New Zealand and its fauna. Trends in Ecology \& Evolution, 8(12), 437-442.

Diamond, J. M. (1984). Distributions of New Zealand birds on real and virtual islands. New Zealand journal of ecology, 37-55.

Dawson, J. (1988). Forest vines to snow tussocks. Victoria University Press, Wellington. 
de Lange, P. (2013). New Endemic Plants for the Chatham Islands. Retrieved from http://www.chathams.co.nz/index.php/naturalheritage/151-new-endemic-plants-forthe-chatham-islands

deLange, P. J., Cameron, E. K., \& Murray, B. G. (1999). Alectryon excelsus subsp. grandis (Sapindaceae): a new combination for an uncommon small tree endemic to the Three Kings Islands, New Zealand. New Zealand Journal of Botany, 37(1), 7-16.

de Lange, P. J., Heenan, P. B., Houliston, G. J., Rolfe, J. R., \& Mitchell, A. D. (2013). New lepidium (brassicaceae) from New Zealand. PhytoKeys, (24), 1.

Department of Environment and Climate Change (NSW). (2007). Lord Howe Island Biodiversity Management Plan Appendices, Department of Environment and Climate Changes (NSW), Sydney.

Drezner, T. D. (2003). Revisiting Bergmann's rule for saguaros (Carnegiea gigantea (Engelm.) Britt. and Rose): stem diameter patterns over space. Journal of Biogeography, 30(3), 353-359.

Edwards, K. J., \& Gadek, P. A. (2001). Evolution and biogeography of Alectryon (Sapindaceae). Molecular Phylogenetics and Evolution, 20(1), 14-26.

Enquist, B. J., Tiffney, B. H., \& Niklas, K. J. (2007). Metabolic scaling and the evolutionary dynamics of plant size, form, and diversity: toward a synthesis of ecology, evolution, and paleontology. International Journal of Plant Sciences, 168(5), 729-749.

Evans, K. (2018). Return of the Lost Birds. New Zealand National Geographic. Retrieved fromhttps://www.nzgeo.com/stories/return-of-the-lost-birds/

Falkland, A., \& Custodio, E. (1991). Hydrology and water resources of small islands: A practical guide (No. 49). Unesco, Paris.

Faurby, S., \& Svenning, J. C. (2016). Resurrection of the island rule: human-driven extinctions have obscured a basic evolutionary pattern. The American Naturalist, 187(6), 812-820.

Fell, D. (2002). Campbell Island: Land of the blue sunflower. David Bateman.

Federman, S., Dornburg, A., Downie, A., Richard, A. F., Daly, D. C., \& Donoghue, M. J. (2015). The biogeographic origin of a radiation of trees in Madagascar: implications for the assembly of a tropical forest biome. BMC evolutionary biology, 15(1), 216.

Fitter, A. H., Fitter, R. S. R., Harris, I. T. B., \& Williamson, M. H. (1995). Relationships between first flowering date and temperature in the flora of a locality in central England. Functional Ecology, 55-60.

Foster, J. B. (1964). Evolution of mammals on islands. Nature, 202, 234-235.

Flora of Australia volume 49. (1994). Oceanic Islands 1. Australian Government Publishing Service, Canberra.

Floraseries (2004). Flora of New Zealand Series. Retrieved from: floraseries.landcareresearch.co.nz

Futuyma, D. J. (2009). Coevolution. In Encyclopedia of Insects(pp. 175-179). Academic Press. 
Gallaher, T., Callmander, M. W., Buerki, S., \& Keeley, S. C. (2015). A long distance dispersal hypothesis for the Pandanaceae and the origins of the Pandanus tectorius complex. Molecular phylogenetics and evolution, 82, 20-32.

Gardner, J. J., Perrie, L., Shepherd, L., \& Nagalingum, N. S. (2017). Taxonomic Placement of Unassigned Species of Lastreopsid Ferns (Dryopteridaceae) Using Phylogeny. Systematic Botany, 42(3), 385-391.

Gardiner, B., Berry, P., \& Moulia, B. (2016). Wind impacts on plant growth, mechanics and damage. Plant Science, 245, 94-118.

Glenny, D. (2003). A revision of the genus Gentianella in New Zealand. University of Canterbury, Canterbury.

GBIF (2018). Global Biodiversity Information Facility. Retrieved from: https://api.gbif.org/v1/image/unsafe/http\%3A\%2F\%2Fmedia.canadensys.net\%2Fmtspecimens\%2Flarge\%2FMT00198017.jpg.

Gillespie, R. G., Baldwin, B. G., Waters, J. M., Fraser, C. I., Nikula, R., \& Roderick, G. K. (2012). Long-distance dispersal: a framework for hypothesis testing. Trends in ecology \& evolution, 27(1), 47-56.

Givnish, T. J. (1998). Adaptive plant evolution on islands: classical patterns, molecular data, and new insights. Evolution on islands, 281-304.

Givnish, T. J., Wong, S. C., Stuart-Williams, H., Holloway-Phillips, M., \& Farquhar, G. D. (2014). Determinants of maximum tree height in Eucalyptus species along a rainfall gradient in Victoria, Australia. Ecology, 95(11), 2991-3007.

Gould, S. J. (1997). Cope's rule as psychological artefact. Nature, 385, 199-200.

Graham, G. C., Henry, R. J., Godwin, I. D., \& Nikles, D. G. (1996). Phylogenetic position of Hoop pine (Araucaria cunninghamii). Australian Systematic Botany, 9(6), 893-902.

Grant, P. R. (1998). Patterns on islands and microevolution. Evolution on Islands. Oxford University Press, Oxford, 1-17.

Grant, P. R., \& Grant, B. R. (2002). Adaptive radiation of Darwin's finches: Recent data help explain how this famous group of Galapagos birds evolved, although gaps in our understanding remain. American Scientist, 90(2), 130-139.

Greene, D. F., \& Johnson, E. A. (1993). Seed mass and dispersal capacity in wind-dispersed diapores. Oikos, 67, 69-69.

Hallström, B. M., \& Janke, A. (2010). Mammalian evolution may not be strictly bifurcating. Molecular biology and evolution, 27(12), 2804-2816.

Hanken, J., \& Wake, D. B. (1993). Miniaturization of body size: organismal consequences and evolutionary significance. Annual Review of Ecology and Systematics, 24(1), 501-519.

Hanley, M. E., Lamont, B. B., Fairbanks, M. M., \& Rafferty, C. M. (2007). Plant structural traits and their role in anti-herbivore defence. Perspectives in Plant Ecology, Evolution and Systematics, 8(4), 157-178. 
Harvey, P. H., \& Pagel, M. D. (1991). The comparative method in evolutionary biology (Vol. 239). Oxford: Oxford university press.

Heaney, L. R. (1978). Island area and body size of insular mammals: evidence from the tricolored squirrel (Callosciurus prevosti) of Southeast Asia. Evolution, 32(1), 29-44.

Heenan, P. B. (1998). Phylogenetic analysis of the Carmichaelia complex, Clianthus, and Swainsona (Fabaceae), from Australia and New Zealand. New Zealand journal of botany, 36, 21-40.

Heenan, P. B., Mitchell, A. D., De Lange, P. J., Keeling, J., \& Paterson, A. M. (2010). LateCenozoic origin and diversification of Chatham Islands endemic plant species revealed by analyses of DNA sequence data. New Zealand Journal of Botany, 48(2), 83-136.

Herrera, E. A. (1989). Coevolution of reproductive characteristics in 12 species of New World figs and their pollinator wasps. Experientia, 45(7), 637-647.

Hidayat, T., Weston, P. H., Yukawa, T., Ito, M., \& Rice, R. (2012). Phylogeny of subtribe Aeridinae (Orchidaceae) inferred from DNA sequences data: Advanced analyses including Australasian genera. J Teknol, 59, 87-95.

Hogg, R. V., Tanis, E. A., \& Zimmerman, D. L. (2010). Probability and statistical inference (Vol. 200). New Jersey: Prentice Hall.

Howarth, D. G., Gustafsson, M. H., Baum, D. A., \& Motley, T. J. (2003). Phylogenetics of the genus Scaevola (Goodeniaceae): implication for dispersal patterns across the Pacific Basin and colonization of the Hawaiian Islands. American Journal of Botany, 90(6), 915-923.

Hu, S., Dilcher, D. L., Jarzen, D. M., \& Taylor, D. W. (2008). Early steps of angiosperm-pollinator coevolution. Proceedings of the National Academy of Sciences, 105(1), 240-245.

Huelsenbeck, J. P., \& Kirkpatrick, M. (1996). Do phylogenetic methods produce trees with biased shapes?. Evolution, 50(4), 1418-1424.

Hutton, I. (2002). A field guide to the plants of Lord Howe Island. Ian Hutton.

Inoue, K. (1990). Evolution of mating systems in island populations of Campanula microdonta: pollinator availability hypothesis. Plant species biology, 5(1), 57-64.

Inoue, K., Maki, M., \& Masuda, M. (1996). Evolution of Campanula flowers in relation to insect pollinators on islands. In Floral biology (pp. 377-400). Springer, Boston, MA.

Itescu, Y., Karraker, N. E., Raia, P., Pritchard, P. C., \& Meiri, S. (2014). Is the island rule general? Turtles disagree. Global Ecology and Biogeography, 23(6), 689-700.

Jaffe, A. L., Slater, G. J., \& Alfaro, M. E. (2011). The evolution of island gigantism and body size variation in tortoises and turtles. Biology letters, rsbl20101084.

Jordano, P. (1987). Patterns of mutualistic interactions in pollination and seed dispersal: connectance, dependence asymmetries, and coevolution. The American Naturalist, 129(5), 657-677. 
Kamijo, T., \& Hashiba, K. (2003). Island ecosystem and vegetation dynamics before and after the 2000-Year eruption on Miyake-jima island, Japan, with implications for conservation of the island's ecosystem. GLOBAL ENVIRONMENTAL RESEARCH-ENGLISH EDITION-, 7(1), 69-78.

Kavanagh, P. H., \& Burns, K. C. (2014). The repeated evolution of large seeds on islands. Proceedings of the Royal Society of London B: Biological Sciences, 281(1786), 20140675.

Kavanagh, P. (2015). Macroevolutionary Changes of Plants on Islands. Victoria University of Wellington, Wellington.

Kavanagh, P. H., \& Burns, K. C. (2015). Sexual size dimorphism in island plants: the niche variation hypothesis and insular size changes. Oikos, 124(6), 717-723.

Keeling, J., Gardner, R. \& de Lange. P. (2004) An inferred molecular phylogeny from nrDNA ITS sequences for Pennantia (Pennantiaceae). New Zealand Botanical Society Newsletter, 76, 2427.

Kim, S. C., Chunghee, L., \& Mejías, J. A. (2007). Phylogenetic analysis of chloroplast DNA matK gene and ITS of nrDNA sequences reveals polyphyly of the genus Sonchus and new relationships subtribe Sonchinae (Asteraceae: Cichorieae). Molecular Phylogenetics and Evolution, 44(2), 578-597.

Klak, C., Hanáček, P., \& Bruyns, P. V. (2017). Out of southern Africa: Origin, biogeography and age of the Aizooideae (Aizoaceae). Molecular phylogenetics and evolution, 109, 203-216

Kohn, D. D., \& Walsh, D. M. (1994). Plant species richness--the effect of island size and habitat diversity. Journal of Ecology, 367-377.

Kritsky, G. (1991). Darwin's Madagascan hawk moth prediction. American Entomologist, 37(4), 206-210.

Lawlor, T. E. (1982). The evolution of body size in mammals: evidence from insular populations in Mexico. The American Naturalist, 119(1), 54-72.

Leger, E. A. (2013). Annual plants change in size over a century of observations. Global Change Biology, 19(7), 2229-2239.

Lehnebach, C. A. (2008). Phylogenetic affinities, species delimitation and adaptive radiation of New Zealand Ranunculus: a thesis presented in partial fulfilment of the requirements for the degree of Doctor of Philosophy in Plant Biology at Massey University, Palmerston North, New Zealand (Doctoral dissertation, Massey University).

Lehnebach, C. A., Zeller, A. J., Frericks, J., \& Ritchie, P. (2016). Five new species of Corybas (Diurideae, Orchidaceae) endemic to New Zealand and phylogeny of the Nematoceras clade. Phytotaxa, 270(1), 1-24.

Lens, F., Davin, N., Smets, E., \& del Arco, M. (2013). Insular woodiness on the Canary Islands: a remarkable case of convergent evolution. International Journal of Plant Sciences, 174(7), 9921013. 
Lewis, R. (2001). Molecular studies on the New Zealand tree ferns: a thesis submitted in partial fulfillment of the requirements for the degree of Master of Science in Plant Biology at Massey University, Palmerston North, New Zealand(Doctoral dissertation, Massey University).

Liew, C. S., Memory, A. E., Ortiz-Barrientos, D., De Lange, P. J., \& Pelser, P. B. (2018). The delimitation and evolutionary history of the Australasian Lautusoid group of Senecio (Asteraceae: Senecioneae). Taxon, 67(1), 130-148.

Lister, A. M. (1989). Rapid dwarfing of red deer on Jersey in the last interglacial. Nature, 342(6249), 539.

Little, L., Eidesen, P. B., Müller, E., Dickinson, K. J., \& Lord, J. M. (2016). Leaf and floral heating in cold climates: do sub-Antarctic megaherbs resemble tropical alpine giants?. Polar Research, 35(1), 26030.

Lloyd, D.G. 1972: A revision of the New Zealand, Subantarctic, and South American species of Cotula, section Leptinella. New Zealand Journal of Botany 10: 277-372.

Lokatis, S., \& Jeschke, J. M. (2018). The island rule: An assessment of biases and research trends. Journal of Biogeography, 45(2), 289-303.

Lomolino, M. V. (1985). Body size of mammals on islands: the island rule reexamined. The American Naturalist, 125(2), 310-316.

Lomolino, M. V. (2005). Body size evolution in insular vertebrates: generality of the island rule. Journal of Biogeography, 32(10), 1683-1699.

Lomolino, M. V., Sax, D. F., Riddle, B. R., \& Brown, J. H. (2006). The island rule and a research agenda for studying ecogeographical patterns. Journal of Biogeography, 33(9), 1503-1510.

Lord, J. M. (2015). Patterns in floral traits and plant breeding systems on Southern Ocean Islands. AoBPlants, 7.

Lord, J. M., Huggins, L., Little, L. M., \& Tomlinson, V. R. (2013). Floral biology and flower visitors on subantarctic Campbell Island. New Zealand Journal of Botany, 51(3), 168-180.

Louw, A. (2016). Plant functional types on Marion Island(Doctoral dissertation, Stellenbosch: Stellenbosch University).

MacArthur, R. H., \& Wilson, E. O. (2001). The theory of island biogeography (Vol. 1). Princeton University Press.

Marczyk, G., DeMatteo, D., \& Festinger, D. (2005). Essentials of research design and methodology. John Wiley \& Sons Inc.

McCauley, R. A., \& Havran, J. C. (2013) Biogeographic origins and the evolution of woodiness in the endemic Hawaiian genus Nototrichium (Amaranthaceae: Amaranthoideae).

McNab, B. K. (1971). On the ecological significance of Bergmann's rule. Ecology, 52(5), 845854.

Meiri, S. (2004). Carnivore body size: aspects of geographic variation. Tel Aviv University.

Meiri, S., Cooper, N., \& Purvis, A. (2007). The island rule: made to be broken?. Proceedings of the Royal Society of London B: Biological Sciences, 275(1631), 141-148. 
Milach, S. C. K., \& Federizzi, L. C. (2001). Dwarfing genes in plant improvement.

Mitchell, A. D., \& Heenan, P. B. (2002). Sophora sect. Edwardsia (Fabaceae): further evidence from nrDNA sequence data of a recent and rapid radiation around the Southern Oceans. Botanical Journal of the Linnean Society, 140(4), 435-441.

Mitchell, A. D., Heenan, P. B., Murray, B. G., Molloy, B. P. J., \& De Lange, P. J. (2009). Evolution of the south-western Pacific genus Melicytus (Violaceae): evidence from DNA sequence data, cytology and sex expression. Australian Systematic Botany, 22(3), 143-157.

Mitchell, A. D., Meurk, C. D., \& Wagstaff, S. J. (1999). Evolution of Stilbocarpa, a megaherb from New Zealand's sub-antarctic islands. New Zealand Journal of Botany, 37(2), 205-211.

Mosquin, T. (1971). Competition for pollinators as a stimulus for the evolution of flowering time. Oikos, 398-402.

Murdock, A. G. (2008). Phylogeny of marattioid ferns (Marattiaceae): inferring a root in the absence of a closely related outgroup. American Journal of Botany, 95(5), 626-641.

Nathan, R. (2006). Long-distance dispersal of plants. Science, 313(5788), 786-788.

New Zealand Plant Conservation Network (2018) Vascular flora. Retrieved from http://www.nzpcn.org.nz/page.aspx?flora

Nicolas, A. N., \& Plunkett, G. M. (2012). Untangling generic limits in Azorella, Laretia, and Mulinum (Apiaceae: Azorelloideae): insights from phylogenetics and biogeography. Taxon, 61(4), 826-840.

Niering, W. A., Whittaker, R. H., \& Lowe, C. H. (1963). The saguaro: a population in relation to environment. Science, 142(3588), 15-23.

Niklas, K. J. (1994). Plant allometry: the scaling of form and process. University of Chicago Press.

NZCPN (2018). New Zealand Plant Conservation Network. Retrieved from: http://www.nzpcn.org.nz/

NZFLORA (2018). New Zealand Flora. Retrieved from: http://www.nzflora.info/

Oliver, W. R. B. (1948). The flora of the Three Kings Islands. Records of the Auckland Institute and Museum, 3(4/5), 211-238.

Ollerton, J., Killick, A., Lamborn, E., Watts, S., \& Whiston, M. (2007). Multiple meanings and modes: on the many ways to be a generalist flower. Taxon, 56(3), 717-728.

Ohlsen, D. J., Perrie, L. R., Shepherd, L. D., Brownsey, P. J., \& Bayly, M. J. (2015). Phylogeny of the fern family Aspleniaceae in Australasia and the south-western Pacific. Australian Systematic Botany, 27(6), 355-371.

Olesen, J. M., \& Jordano, P. (2002). Geographic patterns in plant-pollinator mutualistic networks. Ecology, 83(9), 2416-2424.

Palkovacs, E. P. (2003). Explaining adaptive shifts in body size on islands: a life history approach. Oikos,103(1), 37-44. 
Palmpedia (2015). Palm Encyclopedia. Retrieved from: http://www.palmpedia.net/wiki/Main Page

Panitsa, M., Tzanoudakis, D., Triantis, K. A., \& Sfenthourakis, S. (2006). Patterns of species richness on very small islands: the plants of the Aegean archipelago. Journal of Biogeography, 33(7), 1223-1234.

Papadopulos, A. S., Baker, W. J., Crayn, D., Butlin, R. K., Kynast, R. G., Hutton, I., \& Savolainen, V. (2011). Speciation with gene flow on Lord Howe Island supplementary material. Proceedings of the National Academy of Sciences,108(32), 13188-13193.

Panero, J. L., Francisco-Ortega, J., Jansen, R. K., \& Santos-Guerra, A. (1999). Molecular evidence for multiple origins of woodiness and a New World biogeographic connection of the Macaronesian Island endemic Pericallis (Asteraceae: Senecioneae). Proceedings of the National Academy of Sciences, 96(24), 13886-13891.

Percy, D. M., \& Cronk, Q. C. (2002). Different fates of island brooms: contrasting evolution in Adenocarpus,Genista, and Teline (Genisteae, Fabaceae) in the Canary Islands and Madeira. American Journal of Botany, 89(5), 854-864.

Perrie, L. R., \& Brownsey, P. J. (2012). Lastreopsis kermadecensis, a new fern species from Raoul Island in the Kermadec Islands, New Zealand, with notes on L. pacifica. New Zealand journal of botany, 50(1), 29-36.

Perrie, L. R., \& Shepherd, L. D. (2009). Reconstructing the species phylogeny of Pseudopanax (Araliaceae), a genus of hybridising trees. Molecular Phylogenetics and Evolution, 52(3), 774-783.

Perrie, L. R., Wilson, R. K., Shepherd, L. D., Ohlsen, D. J., Batty, E. L., Brownsey, P. J., \& Bayly, M. J. (2014). Molecular phylogenetics and generic taxonomy of Blechnaceae ferns. Taxon, 63(4), 745-758.

Phillips,

J. (2012) Subantartic Islands.

Retrieved

from: http://www.TeAra.govt.nz/en/subantarctic-islands

Pickup, M., \& Barrett, S. C. (2011). Reversal of height dimorphism promotes pollen and seed dispersal in a wind-pollinated dioecious plant. Biology letters, 8(2), 245-248.

PlantNET (2018). New South Wales Flora. Retrieved from: http://plantnet.rbgsyd.nsw.gov.au/search/simple.htm

Poulakakis, N., Mylonas, M., Lymberakis, P., \& Fassoulas, C. (2002). Origin and taxonomy of the fossil elephants of the island of Crete (Greece): problems and perspectives. Palaeogeography, Palaeoclimatology, Palaeoecology, 186(1-2), 163-183.

Primack, R. B. (1987). Relationships among flowers, fruits, and seeds. Annual review of ecology and systematics, 18(1), 409-430.

Raia, P., \& Meiri, S. (2011). The tempo and mode of evolution: body sizes of island mammals. Evolution, 65(7), 1927-1934. 
Radford, E. A., Watson, M. F., \& Preston, J. (2001). Phylogenetic relationships of species of Aciphylla (Apiaceae, subfamily Apioideae) and related genera using molecular, morphological, and combined data sets. New Zealand Journal of Botany, 39(2), 183-208.

Rance, B. (2018). Sub-Antarctic Plant Checklist. Unpublished raw data

Rarepalmseeds.com (2018). Rare palms. Retrieved from: https://www.rarepalmseeds.com/

Reid, C. S., Carter, R., \& Urbatsch, L. E. (2014). Phylogenetic insights into New World Cyperus (Cyperaceae) using nuclear ITS sequences. Brittonia, 66(3), 292-305.

Roth, V. L. (1990). Insular dwarf elephants: a case study in body mass estimation and ecological inference. Body size in mammalian paleobiology: estimation and biological implications. Cambridge University Press, New York, 151-179.

Rosenzweig, C., Tubiello, F. N., Goldberg, R., Mills, E., \& Bloomfield, J. (2002). Increased crop damage in the US from excess precipitation under climate change. Global Environmental Change, 12(3), 197-202.

Ruan, C. J., Chen, S. C., Li, Q., \& da Silva, J. A. T. (2011). Adaptive evolution of context-dependent style curvature in some species of the Malvaceae: a molecular phylogenetic approach. Plant systematics and evolution, 297(1-2), 57.

Ruhsam, M., Rai, H. S., Mathews, S., Ross, T. G., Graham, S. W., Raubeson, L. A., Mei, W., Thomas, P. I., Gardner, A. F., Ennos, R. A., \& Hollingsworth, P. M. (2015). Does complete plastid genome sequencing improve species discrimination and phylogenetic resolution in Araucaria?. Molecular ecology resources, 15(5), 1067-1078.

Savolainen, V., Anstett, M., Lexer, C., Hutton, I., Clarkson, J., Norup, M., Powell, M., Springate, D.,Salamin, N., \& Baker, W. (2006). Sympatric speciation in palms on an oceanic island. Nature, 441(7090), 210.

Schleuning, M., Fründ, J., Klein, A. M., Abrahamczyk, S., Alarcón, R., Albrecht, M., Andersson, G. K. S., Bazarian, S., Bohninh-Gaese, K., Bommarco, R., Dalsgaard, B., Dehling, D., Gotlieb, A., Hagen, M., Hickler, T., Holzschuh, A., Kaiser-Bunbury, C., Kreft, H., Morris, R., Sandel, B., Sutherland, W. J., Svenning, J., Tscharntke, T., Watta, A., Weiner, C., Werner, M., Williams, N., Winqvist, C., Dormann, C. F., \& Dalsgaard, B. (2012). Specialization of mutualistic interaction networks decreases toward tropical latitudes. Current biology, 22(20), 1925-1931.

Schluter, D. (2000). Ecological character displacement in adaptive radiation. The American Naturalist, 156(S4), S4-S16.

Shahjahan, A. K. M., Duve, T., \& Bonman, J. M. (1987). Climate and rice diseases. Weather and Rice. International Rice Research Institute, Los Baños, Philippines, 125-137.

Shinohara, W., \& Murakami, N. (2006). How have the alpine dwarf plants in Yakushima been miniaturized? A comparative study of two alpine dwarf species in Yakushmia, Blechnum niponicum (Blechnaceae) and Lysimachia japonica (Primulaceae). Journal of plant research, 119(6), $571-580$.

Smissen, R. D., Breitwieser, I., Ward, J. M., McLenachan, P. A., \& Lockhart, P. J. (2003). Use of ISSR profiles and ITS-sequences to study the biogeography of alpine cushion plants in the genus Raoulia (Asteraceae). Plant Systematics and Evolution, 239(1-2), 79-94. 
Sondaar, P. Y. (1977). Insularity and its effect on mammal evolution. In Major patterns in vertebrate evolution (pp.671-707). Springer, Boston, MA.

Stajsic, V., Walsh, N. G., Douglas, R., Messina, A., \& Molloy, B. P. J. (2015). A revision of Melicytus (Violaceae) in mainland Australia and Tasmania. Australian systematic botany, 27(4), 305-323.

Stöckler, K. (2001). Origins and evolution of the New Zealand forest flora: a molecular phylogenetic approach: a thesis presented in partial fulfilment of the requirements for the degree of Doctor of Philosophy in Plant Biology at Massey University, Palmerston North, New Zealand (Doctoral dissertation, Massey University).

Stuessy, T. F., Jakubowsky, G., Gómez, R. S., Pfosser, M., Schlüter, P. M., Fer, T., Sun, B., \& Kato, H. (2006). Anagenetic evolution in island plants. Journal of Biogeography, 33(7), 1259-1265.

Sultan, A. (2014). Systematics, biology and ecology of New Zealand's pygmy mistletoes (Korthalsella: Viscaceae): a thesis presented in partial fulfilment of the requirements for the degree of Doctor of Philosophy in Ecology at Massey University, Manawatu, New Zealand (Doctoral dissertation, Massey University).

Sun, S., Jin, D., \& Shi, P. (2005). The leaf size-twig size spectrum of temperate woody species along an altitudinal gradient: an invariant allometric scaling relationship. Annals of Botany, 97(1), 97-107.

Sun, Z. S., Zhou, W., JIN, X., Ohi-Toma, T., Li, P., \& Fu, C. X. (2016). A tale of two islands: parallel evolution of dwarfism in Smilax biflora (Smilacaceae). Phytotaxa, 245(2), 089-106.

Takayama, K., Sun, B. Y., \& Stuessy, T. F. (2013). Anagenetic speciation in Ullung Island, Korea: genetic diversity and structure in the island endemic species, Acer takesimense (Sapindaceae). Journal of plant research, 126(3), 323-333.

Tay, M. L., Meudt, H. M., Garnock-Jones, P. J., \& Ritchie, P. A. (2010). Testing species limits of New Zealand Plantago (Plantaginaceae) using internal transcribed spacer (ITS) DNA sequences. New Zealand Journal of Botany, 48(3-4), 205-224.

Tsukaya, H., Tsujino, R., Ikeuchi, M., Isshiki, Y., Kono, M., Takeuchi, T., \& Araki, T. (2007). Morphological variation in leaf shape in Ainsliaea apiculata with special reference to the endemic characters of populations on Yakushima Island, Japan. Journal of plant research, 120(3), 351-358.

van der Geer, A. A., Lyras, G. A., Mitteroecker, P., \& MacPhee, R. D. (2018). From Jumbo to Dumbo: Cranial Shape Changes in Elephants and Hippos During Phyletic Dwarfing. Evolutionary Biology, 1-15.

Van Valen, L. (1973). Body size and numbers of plants and animals. Evolution, 27(1), 27-35.

Vasconcelos, T. N., \& Proença, C. E. (2015). Floral cost vs. floral display: insights from the megadiverse Myrtales suggest that energetically expensive floral parts are less phylogenetically constrained. American journal of botany, 102(6), 900-909.

Vicflora (2018). Flora of Victoria. Retrieved from: https://vicflora.rbg.vic.gov.au/ 
Von Hagen, K. B., \& Kadereit, J. W. (2001). The phylogeny of Gentianella (Gentianaceae) and its colonization of the southern hemisphere as revealed by nuclear and chloroplast DNA sequence variation. Organisms Diversity \& Evolution, 1(1), 61-79.

Wagstaff, S. J., \& Breitwieser, I. (2004). Phylogeny and classification of Brachyglottis (Senecioneae, Asteraceae): an example of a rapid species radiation in New Zealand. Systematic Botany, 29(4), 1003-1010.

Wagstaff, S. J., Breitwieser, I., \& Ito, M. (2011). Evolution and biogeography of Pleurophyllum (Astereae, Asteraceae), a small genus of megaherbs endemic to the subantarctic islands. American Journal of Botany, 98(1), 62-75.

Wagstaff, S. J., Breitwieser, I., \& Swenson, U. (2006). Origin and relationships of the austral genus Abrotanella (Asteraceae) inferred from DNA sequences. Taxon, 55(1), 95-106.

Wagstaff, S. J., Dawson, M. I., Venter, S., Munzinger, J., Crayn, D. M., Steane, D. A., \& Lemson, K. L. (2010). Origin, Diversification, and Classification of the Australasian Genus Dracophyllum (Richeeae, Ericaceae) 1. Annals of the Missouri Botanical Garden, 235258.

Wallace, A. R. (1832). The Malay Archipelago, Chapter 33 The Aru Islands. Retrieved from:https://ebooks.adelaide.edu.au/w/wallace/alfred russel/malay/chapter33.html

Wallace, A. R. (1891). Natural selection and tropical nature: essays on descriptive and theoretical biology. Macmillan and Company.

Wassersug, R. J., Yang, H., Sepkoski Jr, J. J., \& Raup, D. M. (1979). The evolution of body size on islands: a computer simulation. The American Naturalist, 114(2), 287-295.

Waters, J. M., \& Craw, D. (2006). Goodbye Gondwana? New Zealand biogeography, geology, and the problem of circularity. Systematic Biology, 55(2), 351-356.

Welch, J. J. (2008). Testing the island rule: primates as a case study. Proceedings of the Royal Society B: Biological Sciences, 276(1657), 675-682.

Weller, S. G., Sakai, A. K., Culley, T. M., Campbell, D. R., \& Dunbar-Wallis, A. K. (2006). Predicting the pathway to wind pollination: heritabilities and genetic correlations of inflorescence traits associated with wind pollination in Schiedea salicaria (Caryophyllaceae). Journal of Evolutionary Biology, 19(2), 331-342.

Westoby, M., \& Wright, I. J. (2003). The leaf size-twig size spectrum and its relationship to other important spectra of variation among species. Oecologia, 135(4), 621-628.

Weston, E. M., \& Lister, A. M. (2009). Insular dwarfism in hippos and a model for brain size reduction in Homo floresiensis. Nature, 459(7243), 85.

Whitehead, D. R., \& Jones, C. E. (1969). Small islands and the equilibrium theory of insular biogeography. Evolution, 23(1), 171-179.

Whittaker, R. \& Fernández-Palacios, J. (2007). Island Biogeography Ecology, evolution and conservation. Chippenham, Wiltshire: Antony Rowe Ltd. 
Whittaker, R. J., Fernández-Palacios, J. M., Matthews, T. J., Borregaard, M. K., \& Triantis, K. A. (2017). Island biogeography: Taking the long view of nature's laboratories. Science, 357(6354), eaam8326.

Whittaker, R. J., Rigal, F., Borges, P. A., Cardoso, P., Terzopoulou, S., Casanoves, F., Pla I., Guilhaumon F., Ladle, R., and \& Triantis, K. A. (2014). Functional biogeography of oceanic islands and the scaling of functional diversity in the Azores. Proceedings of the National Academy of Sciences, 111(38), 13709-13714.

Wilson, K. L., \& Morrison, D. A. (Eds.). (2000). Monocots: Systematics and Evolution: Systematics and Evolution. CSIRO PUBLISHING.

Williamson, M. (1981). Island populations. OxfordUniv. Press.

Woo, V. L., Funke, M. M., Smith, J. F., Lockhart, P. J., \& Garnock-Jones, P. J. (2011). New World origins of southwest Pacific Gesneriaceae: multiple movements across and within the South Pacific. International Journal of Plant Sciences, 172(3), 434-457.

Yamada, T., Kodama, K., \& Maki, M. (2014). Floral morphology and pollinator fauna characteristics of island and mainland populations of Ligustrum ovalifolium (Oleaceae). Botanical journal of the Linnean Society, 174(3), 489-501.

Yu, H., Luedeling, E., \& Xu, J. (2010). Winter and spring warming result in delayed spring phenology on the Tibetan Plateau. Proceedings of the National Academy of Sciences, 107(51), 22151-22156.

\section{Image credit}

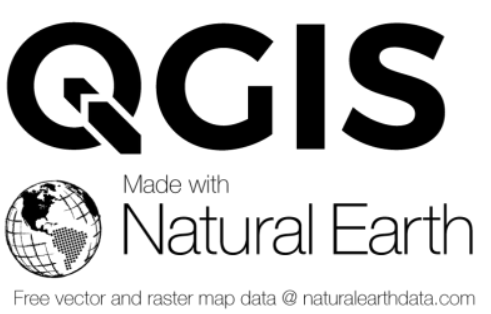

\section{Figure 2.2}

Map of study islands surrounding New Zealand.

Jaz Hamilton, Hamilton Geospatial Solutions Ltd, 2018. Made with Natural Earth. Free vector and raster map data @ naturalearthdata.com. 
List of Herbarium voucher specimens

Table R1: List of Herbarium voucher specimens and their location

\begin{tabular}{|c|c|}
\hline Herbarium & Plant species and voucher codes \\
\hline $\begin{array}{l}\text { Allan Herbarium of Landcare Research } \\
\text { New Zealand Limited (CHR) }\end{array}$ & $\begin{array}{l}\text { Brachyglottis repanda } \\
\bullet \quad \text { CHR 216104 C } \\
\bullet \quad \text { CHR 216104 B } \\
\text { Lepidium oblitum } \\
\bullet \quad \text { CHR 552303 B } \\
\text { Metrosideros excelsa } \\
\text { - CHR296099 } \\
\text { Myrsine aquilonia } \\
\text { - CHR551684 } \\
\text { Senecio hauwai } \\
\bullet \quad \text { CHR 201160 A }\end{array}$ \\
\hline $\begin{array}{l}\text { Auckland War Memorial Museum } \\
\text { Herbarium (AK) }\end{array}$ & 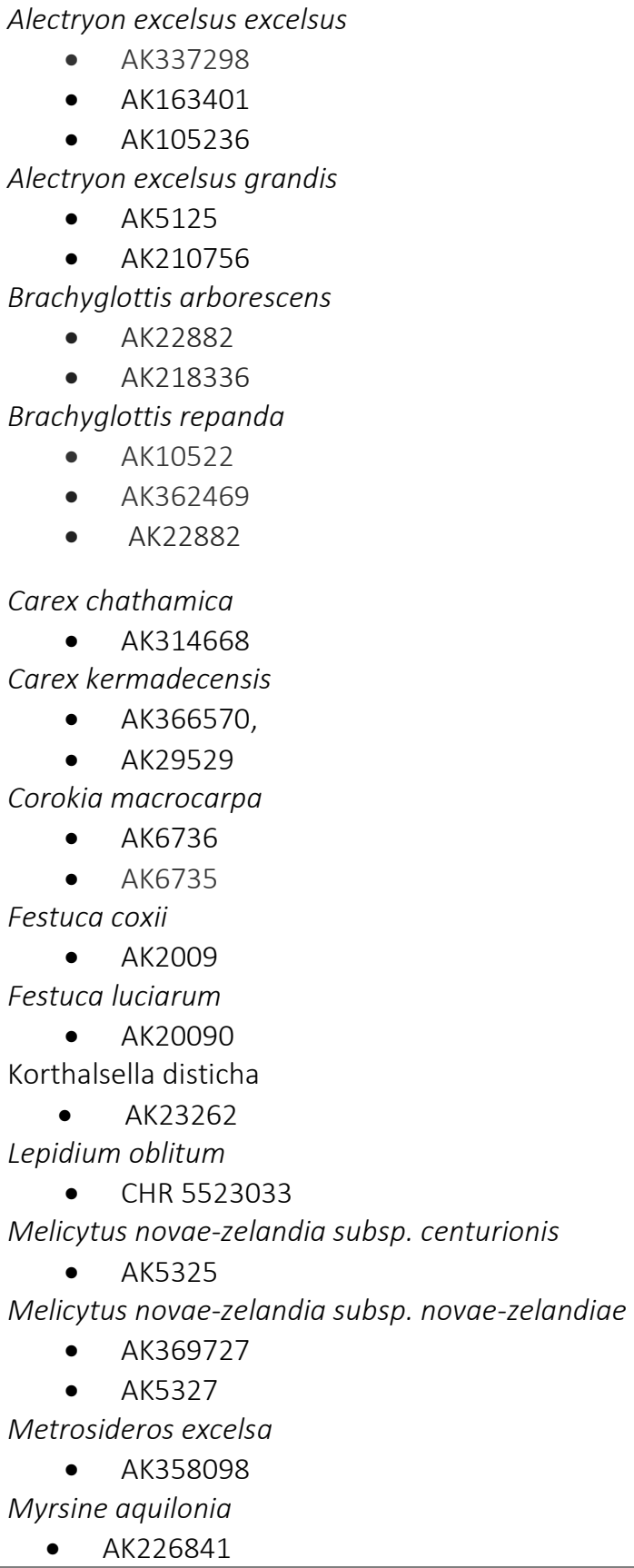 \\
\hline
\end{tabular}


Myrsine chathamica

- AK358264

- AK355715

Pennantia baylisiana

- AK22872

- AK22875

Pittosporum umbellatum

- AK4683

- AK102344,

Pseudopanax chathamicus

- AK6209

Pseudopanax crassifolius

- AK6183

Raoulia buchananii

- AK121993

Senecio minimus

- AK347668

Sonchus novae-zelandiae

- AK304834

Sonchus oleraceus

- AK304834

Veronica insularis

- AK217304,

- AK183138

Botanic Garden and Botanical Museum Berlin-Dahlem, Freie Universität Berlin (B)
Melaleuca ericifolia

- B -W $14365-010$

- B -W $14365-020$

Veronica orchidea

- B-W 00163-01-0

Brachyglottis repanda

- M0030359

Senecio australis

- G00468791

- G00468809,

Exsiccata Europeae Herbarium Veronica orchidea

- 3308

Herbarium, Trinity College, Dublin (TCD) Pittosporum umbellatum

- TCD0010024

- $\quad$ TCD0009989

Herbarium of the Arnold Arboretum (A), Myrsine faberi

Herbier Museum Paris

- A00062246

Coprosma pilosa

- P03819109

Korthalsella dichotoma

- P00078675

- $\quad$ P04697482

- P05066328

- P05097223

- P05066329

Melicope polybotrya

- P05184454

Negria rhabdothamusides

- $\quad$ P03851834

Pittosporum umbellatum

- P02502872 


\begin{tabular}{|c|c|}
\hline & $\begin{array}{ll}\text { Sacromelicope simplicifolia } \\
\text { • } & \text { P00222344 } \\
\text { - } & \text { P05214419 } \\
\text { Veronica orchidea } \\
\text { - } \quad \text { P03516880 } \\
\text { - } \quad \text { P02502869 } \\
\text { Xylosma vincentii } \\
\text { - } \quad \text { P0064888 } \\
\text { - } & \text { P00648881 } \\
\text { - } & 2468816 \\
\text { - } & 15173 \\
\text { - } & \text { P04647112 } \\
\text { - } & \text { P00648882 }\end{array}$ \\
\hline $\begin{array}{l}\text { Linnean Society of London Herbarium } \\
\text { (LINN), } \\
\text { Missouri Botanical gardens }\end{array}$ & $\begin{array}{l}\text { Korthalsella dichotoma } \\
\bullet \quad 2927190 \\
\text { Melaleuca ericifolia } \\
\bullet \quad \text { LINN-HS1243-13 } \\
\text { Myrsine aquilonia } \\
\qquad \quad 2246496 \\
\text { Veronica orchidea } \\
\bullet \quad 102778 \\
\bullet \quad 102776\end{array}$ \\
\hline Martin-Luther-Universität (HAL), & $\begin{array}{c}\text { Cynoglossum paniculatum } \\
\text { • HAL0115079 }\end{array}$ \\
\hline Muse'um National d'Histoire Naturella & $\begin{array}{l}\text { Olearia argophylla } \\
\qquad \quad \text { P00711258 }\end{array}$ \\
\hline National Botanic gardens of Belgium & $\begin{array}{cc}\text { Corokia } & \text { cotoneaster } \\
\bullet & \text { P01900002 } \\
\bullet & \text { BR0000005948567 } \\
\bullet & \text { BR0000005948246 } \\
\text { Myrsine } & \text { platystigma } \\
\text { • } & \text { BR0000005225002 } \\
\text { Pseudopanax crassifolius } \\
\text { • } \quad \text { BR0000005785070 } \\
\text { Sarcomelicope simplicifolia } \\
\text { • } & \text { P00543913 } \\
\text { • } & \text { P00543914 }\end{array}$ \\
\hline $\begin{array}{l}\text { National Herbarium of New South Wales } \\
\text { (NSW) }\end{array}$ & 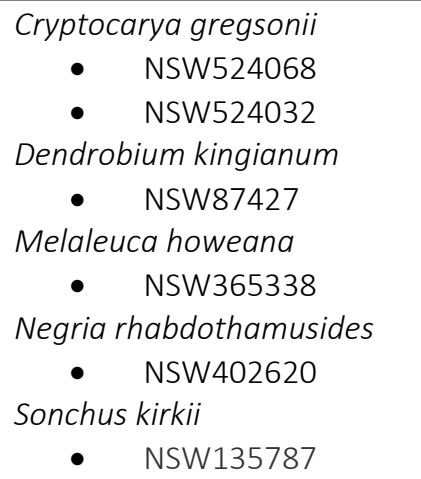 \\
\hline National Herbarium of Victoria (MEL), & $\begin{array}{l}\text { Alyxia squamulosa } \\
\bullet \quad \text { MEL223111 } \\
\bullet \quad \text { MEL223108 } \\
\text { Carmichaelia exsul } \\
\bullet \quad \text { MEL2120317 } \\
\text { Carex tasmanica }\end{array}$ \\
\hline
\end{tabular}




\begin{tabular}{|c|c|}
\hline & $\begin{array}{cc}\bullet & \text { MEL1620511 } \\
\text { Leptinella } & \text { featherstonii } \\
\bullet & \text { MEL42209 } \\
\text { Myrsine platystigma } \\
\text { • } & \text { MEL622061 } \\
\text { Xylosma } & \text { parviflorum } \\
\text { - } & \text { MEL582309 } \\
\text { - } & \text { MEL100642 } \\
\text { - } & \text { MEL582308 } \\
\text { • } & \text { MEL52311 } \\
\text { • } & \text { MEL582310 } \\
\text { • } & \text { MEL100641 } \\
\text { Plectorrhiza tridentata } \\
\text { • } & \text { MEL1540868 }\end{array}$ \\
\hline $\begin{array}{l}\text { Natural History Museum (BM), } \\
\text { BM000810473 }\end{array}$ & $\begin{array}{l}\text { Brachyglottis repanda } \\
\text { - BM000810473 } \\
\text { Pennantia corymbosa } \\
\text { - BM000839739 }\end{array}$ \\
\hline $\begin{array}{l}\text { Naturalis Biodiversity Centre, formerly } \\
\text { Leiden University }\end{array}$ & 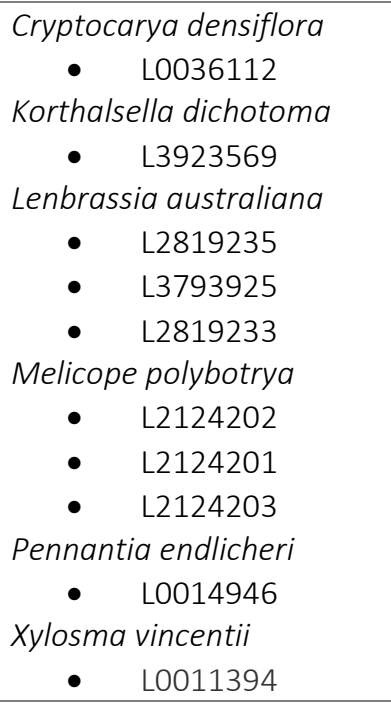 \\
\hline $\begin{array}{l}\text { Naturhistorisches Museum Wien } \\
\text { Botanische Abteilung }\end{array}$ & $\begin{array}{cc}\text { Pittosporum bracteolatum } \\
\text { - } \quad \text { W0046205 } \\
\text { - } & \text { W0046206 }\end{array}$ \\
\hline Royal Botanic Gardens of Edinburgh & $\begin{array}{l}\text { Negria rhabdothamusides } \\
\text { - E00642060 }\end{array}$ \\
\hline Royal Botanic Gardens, Kew (K) & $\begin{array}{l}\text { Abrotanella spathulata } \\
\bullet \quad \text { K000796675 } \\
\text { Alyxia reinwardtii } \\
\bullet \quad \text { H570/97 } 50 \\
\text { Carmichaelia exsul } \\
\bullet \quad \text { K000950835 } \\
\text { Carmichaelia williamsii } \\
\bullet \quad \text { K000950929 } \\
\text { Corokia macrocarpa } \\
\bullet \quad \text { K000739753 } \\
\text { Cynoglossum paniculatum } \\
\bullet \quad \text { K000573727 } \\
\text { Dendrobium kingianum } \\
\bullet \quad \text { K001089618 } \\
\text { Dendrobium moorei } \\
\bullet \quad \text { K001085450 }\end{array}$ \\
\hline
\end{tabular}




\begin{tabular}{|c|c|}
\hline & 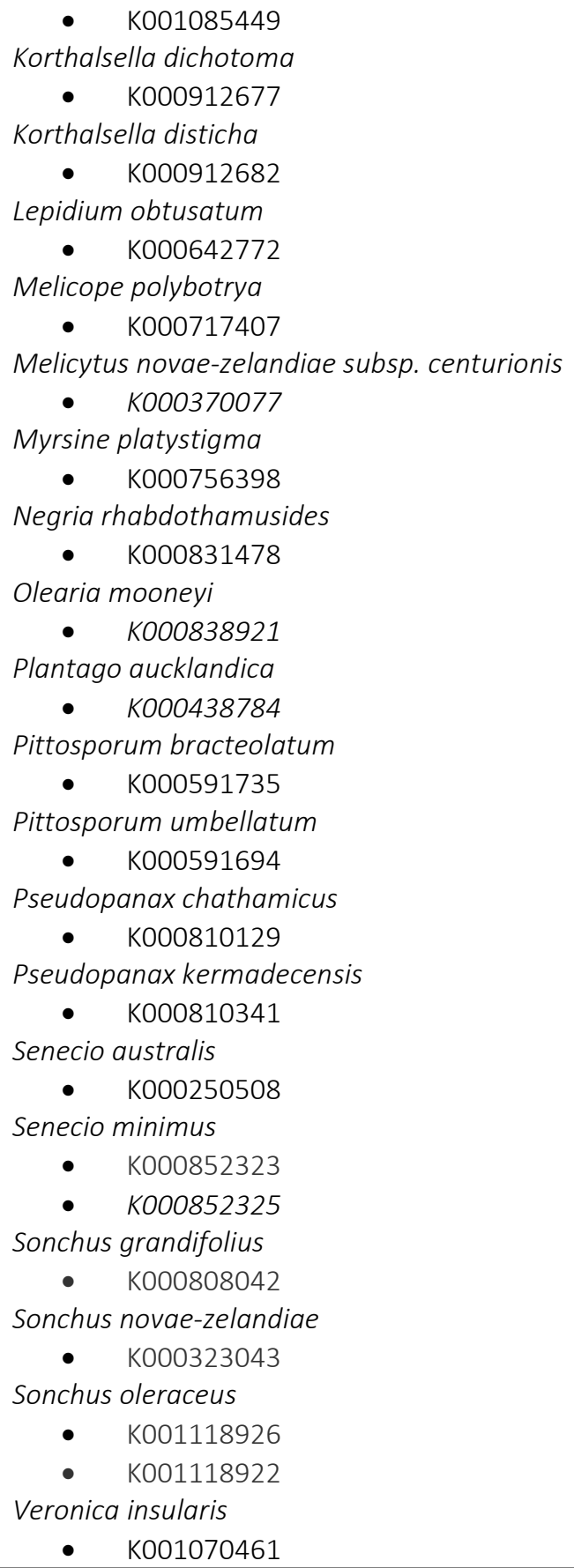 \\
\hline $\begin{array}{l}\text { Swedish Museum of Natural History } \\
\text { Department of Botany }\end{array}$ & $\begin{array}{l}\text { Alyxia reinwardtii } \\
\begin{array}{ll}\text { (S), S-G-10786 }\end{array}\end{array}$ \\
\hline Te Papa Herbarium, Wellington (TP) & $\begin{array}{l}\text { Abrotanella rosulata } \\
\bullet \quad \text { SP102466 } \\
\text { Abrotanella spathulata } \\
\bullet \quad \text { SP57761 } \\
\text { Brachyglottis arborescens } \\
\bullet \quad \text { SP78892 } \\
\bullet \quad \text { SP14393 } \\
\text { Brachyglottis huntii } \\
\bullet \quad \text { SP77964 } \\
\text { Brachyglottis repanda } \\
\bullet \quad \text { SP58743 } \\
\text { Brachyglottis stewartiae }\end{array}$ \\
\hline
\end{tabular}


- SP40512

Coprosma chathamica

- $\quad$ SP097813

- $\quad S P 56390$

Coprosma repens

- SP094169,

- $\quad$ SP101281

Gentianella chathamica subsp. Chathamica

- SP003354

- $\quad$ SP091523 (A)

Gentianella saxosa

- SP47560

- $\quad$ SP47517

Leptinella serrulata

- $\quad$ SP091212

Melicytus novae-zelandia subsp. centurionis

- SP029562

- $\quad S P 029543$

- $\quad S P 029550$

- $\quad S P 067867$

- $\quad S P 085716$

Metrosideros excelsa

- SP023044

Metrosideros kermadecensis

- SP095393

- SP088606

Myosotidia hortensium

- K001067060

Pennantia endlicheri

- SP086322

- SP08611

- $\quad$ SP083238

Pittosporum bracteolatum

- $\quad$ SP084276

Plantago lanigera

- SP104833/A

- SP089135

Pseudopanax arboreus

- SP54311

Pseudopanax chathamicus

- SP25031

- $\quad$ SP3307

- $\quad$ SP3351

- $\quad$ SP25068

Pseudopanax crassifolius

- SP022836

- $\quad$ SP099142

- $\quad$ SP078845

Pseudopanax kermadecensis

- SP05341

Senecio australis

- SP82400

Senecio kermadecensis

- SP90180,

- $\mathrm{SP} 31463$ 
References

Sonchus grandifolius

- SP27962,

- SP27948

The Gray Herbarium (GH)

Cryptocarya densiflora

- GH00041368

United States National Museum

Lenbrassia australiana

- 00453906

Myosotidium hortensia

- 00947912

Universität Göttingen (GOET),

Pseudopanax arboreus

- GOET012768 


\section{Appendices}

\section{Appendix A: Generalised supplementary material Island species checklists}

TableA1 Antipodes Island species checklist

\begin{tabular}{lll}
\hline Antipodes endemic taxa & Available phylogeny & Closest extant mainland relative \\
\hline Puccinellia antipoda & no phylogeny available & - \\
\hline Epilobium sp. aff. alsinoides & no phylogeny available & - \\
\hline $\begin{array}{l}\text { Gentianella antipoda } \\
\text { Keenan, Mitchell, De Lange, } \\
\text { Keeling \& Paterson, 2010 }\end{array}$ & Gentianella cerina \\
\hline $\begin{array}{l}\text { Senecio radiolatus subsp. } \\
\text { antipodus }\end{array}$ & no phylogeny available & - \\
\hline $\begin{array}{l}\text { Stellaria decipiens var. } \\
\text { angustata }\end{array}$ & no phylogeny available & - \\
\hline
\end{tabular}

TableA2 Auckland Island species checklist

\begin{tabular}{lll}
\hline Auckland endemic taxa & Avaliable phylogeny & Closest extant mainland relative \\
\hline Abrotanella spathulata & $\begin{array}{l}\text { Wagstaff, Breitwieser \& } \\
\text { Swenson 2006 }\end{array}$ & $\begin{array}{l}\text { Abrotanella spathulata acts as the } \\
\text { mainland species to Abrotanella } \\
\text { rosulata }\end{array}$ \\
\hline Callitriche aucklandica & no phylogeny available & - \\
\hline $\begin{array}{l}\text { Cardamine depressa var. } \\
\text { depressa }\end{array}$ & no phylogeny available & - \\
\hline Cardamine latior & no phylogeny available & - \\
\hline Gentianella cerina & von Hagen \& Kadereit 2001 & - \\
\hline Gentianella concinna & Glenny 2013 & - \\
\hline Geum albiflorum & no phylogeny available & - \\
\hline Plantago aucklandica & Tay, Meudt, Garnock-Jones \& & Plantago lanigera \\
\hline Plantago triantha & Ritchie, 2010 & - \\
\hline $\begin{array}{l}\text { Poa aucklandica subsp. } \\
\text { aucklandica }\end{array}$ & Tay et al. 2010 & -
\end{tabular}

TableA3 Bounty Island species checklist

\begin{tabular}{lll}
\hline Bounty endemic taxa & Avaliable phylogeny & Closest extant mainland relative \\
\hline Lepidium seditiosum & de Lange, Heenan, Houliston, & - \\
& Rolfe \& Mitchell, 2013 \\
\hline
\end{tabular}

TableA4 Campbell Island species checklist

\begin{tabular}{lll}
\hline Campbell endemic taxa & Avaliable phylogeny & Closest extant mainland relative \\
\hline Abrotanella rosulata & Wagstaff et al., 2006 & Abrotanella spathulata \\
\hline Chionogentias antarctica & no phylogeny available & - \\
\hline $\begin{array}{l}\text { Cardamine depressa var. } \\
\text { stellata }\end{array}$ & no phylogeny available & - \\
\hline Cardamine subcarnosa & no phylogeny available & - \\
\hline Gentianella antarctica & no phylogeny available & - \\
& & - \\
Poa aucklandica subsp. & no phylogeny available &
\end{tabular}


TableA5 Chatham Island species checklist

\begin{tabular}{|c|c|c|}
\hline Chatham endemic taxa & Avaliable phylogeny & Closest extant mainland relative \\
\hline Aciphylla dieffenbachii & Heenan et al. 2010 & - \\
\hline Aciphylla traversii & Heenan et al. 2010 & - \\
\hline Asplenium chathamense & Perrie et al. 2014 & - \\
\hline Austroderia turbaria & no phylogeny found & - \\
\hline Brachyglottis huntii & Heenan et al. 2010 & Brachyglottis stewartiae \\
\hline Carex auceps & no phylogeny found & - \\
\hline Carex chathamica & Heenan et al. 2010 & Carex kermadecensis \\
\hline Carex ventosa & Heenan et al. 2010 & Carex trifida \\
\hline Coprosma chathamica & Heenan et al. 2010 & $\begin{array}{l}\text { Coprosma repens - excluded } \\
\text { from the study, as it seemed } \\
\text { unlikely that dispersal occurred } \\
\text { from the Chathams to Norfolk } \\
\text { Island, especially with the North } \\
\text { Island in the middle of this } \\
\text { dispersal path. More likely that } \\
\text { Coprosma repens (sister taxa to } \\
\text { both C. baueri \& C. chathamica) } \\
\text { dispersed separately to both } \\
\text { Chatham islands and Norfolk } \\
\text { Island. However, introducing C. } \\
\text { repens as mainland relative } \\
\text { deviates from methods, and } \\
\text { causes issues of non } \\
\text { independence. }\end{array}$ \\
\hline $\begin{array}{l}\text { Coprosma propinqua var. } \\
\text { martinii }\end{array}$ & Heenan et al. 2010 & $\begin{array}{l}\text { Coprosma propinqua var. } \\
\text { propinqua }\end{array}$ \\
\hline Corokia macrocarpa & Heenan et al. 2010 & Corokia cotoneaster \\
\hline Disphyma papillatum & Heenan et al. 2010 & - \\
\hline Dracophyllum arboreum & Heenan et al. 2010 & - \\
\hline Festuca coxii & Heenan et al. 2010 & Festuca luciarum \\
\hline $\begin{array}{l}\text { Gentianella chathamica subp. } \\
\text { chathamica }\end{array}$ & Heenan et al. 2010 & Gentianella saxosa \\
\hline Geranium traversii & Heenan et al. 2010 & - \\
\hline Lepidium oblitum & de Lange et al. 2013 & Lepidium obtusatum \\
\hline Lepidium panniforme & de Lange et al. 2013 & - \\
\hline Lepidium rekohuense & de Lange et al. 2013 & - \\
\hline Leptecophylla robusta & Heenan et al. 2010 & Leptecophylla juniperina \\
\hline Leptinella featherstonii & Heenan et al. 2010 & Leptinella serrulata \\
\hline $\begin{array}{l}\text { Linum monogynum var. } \\
\text { chathamicum }\end{array}$ & Heenan et al. 2010 & $\begin{array}{l}\text { Linum monogynum var. } \\
\text { monogynum }\end{array}$ \\
\hline Melicytus chathamicus & Heenan et al. 2010 & - \\
\hline Myosotidium hortensia & Weigend et al. 2013 & Cynoglossum paniculatum \\
\hline Myrsine coxii & Heenan et al. 2010 & Myrsine aquilonia \\
\hline Olearia chathamica & Heenan et al. 2010 & - \\
\hline Olearia semidentata & Heenan et al. 2010 & - \\
\hline Olearia telmatica & Heenan et al. 2010 & - \\
\hline Olearia traversiorum & Heenan et al. 2010 & - \\
\hline
\end{tabular}




\begin{tabular}{lll}
\hline $\begin{array}{l}\text { Plagianthus regius subsp. } \\
\text { chathamicus }\end{array}$ & no phylogeny found & - \\
\hline Poa chathamica & Heenan et al. 2010 & Poa cita \\
\hline Pseudopanax chathamicus & Heenan et al. 2010 & Pseudopanax crassifolius \\
\hline Pterostylis silvicultrix & no phylogeny found & - \\
\hline Rapanea chathamica & Heenan et al. 2010 & - \\
\hline $\begin{array}{l}\text { Senecio radiolatus subsp. } \\
\text { radiolatus }\end{array}$ & no phylogeny found & - \\
\hline Sonchus grandifolius & Heenan et al. 2010 & Sonchus novae-zelandiae \\
\hline Sporadanthus traversii & Heenan et al. 2010 & Sporadanthus ferrugineus \\
\hline Veronica barkeri & Heenan et al. 2010 & - \\
\hline Veronica chathamica & Heenan et al. 2010 & - \\
\hline Veronica dieffenbachii & Heenan et al. 2010 & -
\end{tabular}

TableA6 Kermadec Island species checklist

\begin{tabular}{|c|c|c|}
\hline Kermadec endemic taxa & Avaliable phylogeny & Closest extant mainland relative \\
\hline Ascarina lucida var. lanceolata & No phylogeny found & - \\
\hline Carex kermadecensis & Papadopulos et al. 2011 & $\begin{array}{l}\text { Carex chathamica (C. } \\
\text { kermadecensis acts as the } \\
\text { mainland in this pairing). }\end{array}$ \\
\hline Coprosma acutifolia & Papadopulos et al. 2011 & Coprosma propinqua \\
\hline Coprosma petiolata & Papadopulos et al. 2011 & - \\
\hline $\begin{array}{l}\text { Coriaria arborea var. } \\
\text { kermadecensis }\end{array}$ & No phylogeny found & - \\
\hline Cyathea kermadecensis & No phylogeny found & - \\
\hline Cyathea milnei & Lewis 2001 & Cyathea dealbata \\
\hline Cyperus insularis & Reid, Carter \& Urbatsch, 2014 & Cyperus ustulatus \\
\hline $\begin{array}{l}\text { Disphyma australe subsp. } \\
\text { stricticaule }\end{array}$ & No phylogeny found & - \\
\hline Homalanthus polyandrous & No phylogeny found & - \\
\hline Hypolepis dicksonioides & Perrie et al. 2015 & Hypolepis rugosula \\
\hline Imperata cheesemanii & No phylogeny found & - \\
\hline Lepidium castellanum & de Lange et al. 2013 & - \\
\hline Metrosideros kermadecensis & Papadopulos et al. 2011 & Metrosideros excelsa \\
\hline $\begin{array}{l}\text { Myoporum rapense subsp. } \\
\text { Kermadecense }\end{array}$ & No phylogeny found & - \\
\hline Parapolystichum kermadecense & Perrie \& Brownsey 2012 & - \\
\hline Poa polyphylla & No phylogeny found & - \\
\hline Pouzolzia australis & No phylogeny found & - \\
\hline Pseudopanax kermadecensis & Perrie \& Shepherd 2009 & Pseudopanax arboreus \\
\hline $\begin{array}{l}\text { Rhopalostylis baueri var. } \\
\text { cheesemanii }\end{array}$ & No phylogeny found & - \\
\hline Scaevola gracilis & $\begin{array}{l}\text { Howarth, Gustafsson, Baum \& } \\
\text { Motley, } 2003\end{array}$ & - \\
\hline Senecio kermadecensis & $\begin{array}{l}\text { Liew, Memory, Ortiz- } \\
\text { Barrientos, De Lange \& Pelser, } \\
2018\end{array}$ & Senecio hauwai \\
\hline Sonchus kirkii & Kim, Chunghee \& Mejías, 2007 & Sonchus oleraceus \\
\hline Myrsine kermadecensis & Papadopulos et al. 2011 & - \\
\hline Veronica breviracemosa & No phylogeny found & - \\
\hline
\end{tabular}


TableA7 Lord Howe Island species checklist

\begin{tabular}{|c|c|c|}
\hline Lord Howe endemic taxa & Avaliable phylogeny & Closest extant mainland relative \\
\hline Alyxia squamulosa & Papadopulos et al. 2011 & Alyxia reinwardtii \\
\hline $\begin{array}{l}\text { Apium } \\
\text { prostratum subsp. howense }\end{array}$ & no phylogeny found & - \\
\hline Asplenium goudeyi & $\begin{array}{l}\text { Ohlsen, Perrie, Shepherd, } \\
\text { Brownsey \& Bayly, } 2015\end{array}$ & - \\
\hline Asplenium milnei & Ohlsen et al. 2015 & - \\
\hline Asplenium pteridoides & Ohlsen et al. 2015 & - \\
\hline Asplenium surrogatum & Ohlsen et al. 2015 & - \\
\hline Atractocarpus stipularis & no phylogeny found & - \\
\hline Blechnum contiguum & $\begin{array}{l}\text { Perrie et al. 2014, Papdopulos } \\
\text { et al. } 2011\end{array}$ & - \\
\hline Blechnum fullagarii & $\begin{array}{l}\text { Perrie et al. 2014, Papdopulos } \\
\text { et al. } 2011\end{array}$ & Blechnum nigrum \\
\hline Blechnum geniculatum & no phylogeny found & - \\
\hline Blechnum howeanum & $\begin{array}{l}\text { Perrie et al. 2014, Papdopulos } \\
\text { et al. } 2011\end{array}$ & Blechnum triangularifolium \\
\hline Boehmeria calophleba & no phylogeny found & - \\
\hline Brachyscome segmentosa & no phylogeny found & - \\
\hline Carmichaelia exsul & Heenan 1998 & Carmichaelia williamsii \\
\hline Cassinia tenuifolia & no phylogeny found & - \\
\hline Celtis conferta ssp. amblyphylla & no phylogeny found & - \\
\hline Cephalomanes bauerianum & no phylogeny found & - \\
\hline Chionanthus quadristamineus & no phylogeny found & - \\
\hline Chionochloa howensis & no phylogeny found & - \\
\hline Coprosma huttoniana & Papadopulos et al. 2011 & - \\
\hline Coprosma inopinata & Papadopulos et al. 2011 & - \\
\hline Coprosma lanceolaris & Papadopulos et al. 2011 & - \\
\hline Coprosma prisca & Papadopulos et al. 2011 & Coprosma petiolate \\
\hline Coprosma putida & Papadopulos et al. 2011 & - \\
\hline Coprosma sp. Nov & Papadopulos et al. 2011 & - \\
\hline Corokia carpodetoides & no phylogeny found & - \\
\hline Cryptocarya gregsonii & Papadopulos et al. 2011 & Cryptocarya densiflora \\
\hline Cyathea brevipinna & Papadopulos et al. 2011 & - \\
\hline Cyathea howeana & $\begin{array}{l}\text { Korall et al. } 2007 \\
\text { Papadopulos et al. } 2011\end{array}$ & Cyathea robertsiana \\
\hline Cyathea macarthurii & Papadopulos et al. 2011 & - \\
\hline Cyathea robusta & Papadopulos et al. 2011 & - \\
\hline $\begin{array}{l}\text { Dendrobium macropus ssp. } \\
\text { howeanum }\end{array}$ & no phylogeny found & - \\
\hline Dendrobium moorei & $\begin{array}{l}\text { Papadopulos et al. 2011, } \\
\text { Burke, Bayly, Adams \& Ladiges, } \\
2008\end{array}$ & Dendrobium kingianum \\
\hline Dietes robinsoniana & Wilson \& Morrison 2000, & - \\
\hline Diplazium melanochlamys & no phylogeny found & - \\
\hline Dracophyllum fitzgeraldii & Wagstaff et al. 2010 & - \\
\hline Drypetes deplanchei ssp. affinis & no phylogeny found & - \\
\hline Dysoxylum pachyphyllum & no phylogeny found & - \\
\hline Elaeocarpus costatus & Baba 2013 & - \\
\hline
\end{tabular}




\begin{tabular}{|c|c|c|}
\hline Elatostema grande & no phylogeny found & - \\
\hline Exocarpus homalocladus & no phylogeny found & - \\
\hline $\begin{array}{l}\text { Ficus macrophylla ssp. } \\
\text { columnaris }\end{array}$ & no phylogeny found & - \\
\hline Gahnia howeana & no phylogeny found & - \\
\hline Geniostoma huttonii & Papadopulos et al. 2011 & - \\
\hline Geniostoma petiolosum & Papadopulos et al. 2011 & - \\
\hline Gonocarpus sp & no phylogeny found & - \\
\hline Grammitis diminuta & Papadopulos et al. 2011 & - \\
\hline Grammitis nudicarpa & Papadopulos et al. 2011 & - \\
\hline Grammitis wattsii & Papadopulos et al. 2011 & - \\
\hline Guoia coriacea & no phylogeny found & - \\
\hline Hedyscepe canterburyana & Papadopulos et al. 2011 & Basselinia glabrata \\
\hline Howea belmoreana & Papadopulos et al. 2011 & - \\
\hline Howea forsteriana & Papadopulos et al. 2011 & - \\
\hline Hymenophyllum howense & Papadopulos et al. 2011 & - \\
\hline Hymenophyllum moorei & Papadopulos et al. 2011 & Hymenophyllum baileyanum \\
\hline Korthalsella emersa & Papadopulos et al. 2011 & Korthalsella rubra \\
\hline Lastreopsis nephrodioides & no phylogeny found & - \\
\hline Lepidium howei-insulae & no phylogeny found & - \\
\hline Lepidium nesophilum & de Lange et al. 2013 & - \\
\hline Lepidorrhachis mooreana & no phylogeny found & - \\
\hline Leptopteris moorei & no phylogeny found & - \\
\hline $\begin{array}{l}\text { Leptospermum polygalifolium } \\
\text { ssp. howense }\end{array}$ & no phylogeny found & - \\
\hline Lordhowea insularis & no phylogeny found & - \\
\hline Luzula longiflora & no phylogeny found & - \\
\hline Machaerina insularis & no phylogeny found & - \\
\hline Marattia howeana & Murdock 2008 & - \\
\hline $\begin{array}{l}\text { Marsdenia tubulosa (possibly } \\
\text { extinct) }\end{array}$ & no phylogeny found & - \\
\hline Melaleuca howeana & Brown et al. 2001 & Melaleuca ericifolia \\
\hline Melicope contermina & Papadopulos et al. 2011 & - \\
\hline Melicope polybotrya & Papadopulos et al. 2011 & Sarcomelicope simplicifolia \\
\hline $\begin{array}{l}\text { Melicytus novae-zelandieae } \\
\text { ssp. centurionis }\end{array}$ & $\begin{array}{l}\text { Mitchell, Heenan, Murray, } \\
\text { Molloy \& De Lange, } 2009\end{array}$ & $\begin{array}{l}\text { Melicytus novae-zelandiae } \\
\text { subsp. novae-zelandiae }\end{array}$ \\
\hline Metrosideros nervulosa & Papadopulos et al. 2011 & - \\
\hline Metrosideros sclerocarpa & Papadopulos et al. 2011 & - \\
\hline Myrsine mccomishii & Papadopulos et al. 2011 & - \\
\hline Myrsine myrtillina & Papadopulos et al. 2011 & - \\
\hline Myrsine platystigma & Papadopulos et al. 2011 & Myrsine faberi \\
\hline Negria rhabdothamnoides & $\begin{array}{l}\text { Woo, Funke, Smith, Lockhart \& } \\
\text { Garnock-Jones, } 2011\end{array}$ & Lenbrassia australiana \\
\hline Olearia ballii & Papadopulos et al. 2011 & - \\
\hline $\begin{array}{l}\text { Olearia elliptica ssp. } \\
\text { praetermissa }\end{array}$ & Papadopulos et al. 2011 & - \\
\hline Olearia mooneyi & Papadopulos et al. 2011 & Olearia argophylla \\
\hline Pandanus forsteri & $\begin{array}{l}\text { Gallaher, Callmander, Buerki \& } \\
\text { Keeley, } 2015\end{array}$ & Pandanus kanehirae \\
\hline
\end{tabular}




\begin{tabular}{lll}
\hline $\begin{array}{l}\text { Pandorea pandorana ssp. } \\
\text { austrocaledonia }\end{array}$ & no phylogeny found & - \\
\hline Parsonsia howeana & no phylogeny found & - \\
\hline $\begin{array}{l}\text { Passiflora herbertiana ssp. } \\
\text { insulae-howei }\end{array}$ & no phylogeny found & - \\
\hline $\begin{array}{l}\text { Phymatosorus pustulatus ssp. } \\
\text { Howensis }\end{array}$ & no phylogeny found & - \\
\hline Pimelea congesta & no phylogeny found & - \\
\hline Piper hooglandii & Papadopulos et al. 2011 & - \\
\hline Pittosporum erioloma & no phylogeny found & - \\
\hline Plantago hedleyi & no phylogeny found & - \\
\hline Plectorrhiza erecta & Hidayat, Weston, Yukawa, Ito \& & Plectorrhiza tridentata \\
\hline Polystichum moorei & Rice, 2012 & - \\
\hline Polystichum whiteleggei & Papadopulos et al. 2011 & - \\
\hline Psychotria carronis & Papadopulos et al. 2011 & - \\
\hline Pteris microptera & no phylogeny found & - \\
\hline Scaevola taccada & Papadopulos et al. 2011 & Pteris comans \\
\hline Senecio howeanus & no phylogeny found & - \\
\hline Senecio pauciradiatus & no phylogeny found & - \\
\hline Sophora howinsula & no phylogeny found & - \\
\hline Stephania japonica var & Mitchell \& Heenan 2002 & - \\
timoriensis & no phylogeny found & - \\
\hline Symplocos candelabrum & no phylogeny found & - \\
\hline Syzygium fullargarii (syn. & no phylogeny found & - \\
Cleistocalyx fullargarii) & & - \\
\hline Tetragonia implexicoma & Klak, Hanáček\& Bruyns, 2017 & - \\
\hline possibly extinct) & & - \\
\hline Trophis scandens ssp. \\
megacarpa & no phylogeny found & - \\
\hline Uncinia debilior & no phylogeny found & - \\
\hline Wahlenbergia insulae-howei & no phylogeny found & - \\
\hline Westringia viminalis & no phylogeny found & - \\
\hline Xylosma maidenii & Papadopulos et al. 2011 & - \\
\hline Xylosma parvifolium & Papadopulos et al. 2011 & Xylosma vincentii \\
\hline Bygogynum howeanum (syn. & no phylogeny found & \\
\hline & & - \\
\hline
\end{tabular}

TableA8 Macquarie Island species checklist

\begin{tabular}{lll}
\hline Macquarie endemic taxa & Avaliable phylogeny & Closest extant mainland relative \\
\hline Azorella macquariensis & Nicolas \& Plunkett 2012 & - \\
\hline Corybas dienemus & $\begin{array}{l}\text { Lehnebach, Zeller, Frericks \& } \\
\text { Ritchie, 2016 }\end{array}$ & - \\
\hline Corybas sulcatus & Lehnebach et al. 2016 & - \\
\hline Puccinellia macquariensis & no phylogeny available & - \\
\hline
\end{tabular}

TableA9 Norfolk Island species checklist

\begin{tabular}{lll}
\hline Norfolk endemic taxa & Avaliable phylogeny & Closest extant mainland relative \\
\hline Abutilon julianae & no phylogeny found & - \\
\hline Achyranthes arborescens & McCauley \& Havran, 2013 & - \\
\hline
\end{tabular}




\begin{tabular}{|c|c|c|}
\hline Achyranthes margaretarum & no phylogeny found & - \\
\hline Araucaria heterophylla & $\begin{array}{l}\text { Stefanorić et al. 1998, Ruhsam } \\
\text { et al. 2015, Graham, Henry, } \\
\text { Godwin \& Nikles, } 1996\end{array}$ & Araucaria cunninghamii \\
\hline Asplenium dimorphum & Ohlsen et al. 2015 & Asplenium difforme \\
\hline $\begin{array}{l}\text { Boehmeria australis subsp. } \\
\text { australis }\end{array}$ & no phylogeny found & - \\
\hline Carex neesiana & no phylogeny found & - \\
\hline Clematis dubia & no phylogeny found & - \\
\hline Coprosma baueri & Papadopulos et al. 2011 & $\begin{array}{l}\text { Coprosma chathamica- } \\
\text { excluded from the study see } \\
\text { Coprosma chathamica (Table } \\
\text { A5). }\end{array}$ \\
\hline Coprosma pilosa & Papadopulos et al. 2011 & Coprosma fowerakeri \\
\hline $\begin{array}{l}\text { Cyathea australis subsp. } \\
\text { norfolkensis }\end{array}$ & no phylogeny found & - \\
\hline Cyathea brownii & Papadopulos et al. 2011 & Cyathea robinsonii \\
\hline Dendrobium brachypus & no phylogeny found & - \\
\hline $\begin{array}{l}\text { Dendrobium macropus subsp. } \\
\text { macropus }\end{array}$ & no phylogeny found & - \\
\hline Elatostema montanum & no phylogeny found & - \\
\hline $\begin{array}{l}\text { Elymus multiflorus var. } \\
\text { kingianus }\end{array}$ & no phylogeny found & - \\
\hline Euphorbia norfolkiana & no phylogeny found & - \\
\hline Hibiscus insularis & Ruan, Chen, Li \& da Silva, 2011 & - \\
\hline Korthalsella disticha & Sultan 2014 & Korthalsella dichotoma \\
\hline Lastreopsis calantha & $\begin{array}{l}\text { Gardner, Perrie, Shepherd \& } \\
\text { Nagalingum } 2017\end{array}$ & - \\
\hline Melicope littoralis & no phylogeny found & - \\
\hline Melicytus latifolius & $\begin{array}{l}\text { Stajsic, Walsh, Douglas, } \\
\text { Messina \& Molloy, } 2015\end{array}$ & $\begin{array}{l}\text { Melicytus novae-zelandia } \\
\text { subsp. novae-zelandiae }\end{array}$ \\
\hline $\begin{array}{l}\text { Melicytus ramiflorus subsp. } \\
\text { oblongifolius }\end{array}$ & Stajsic et al. 2015 & - \\
\hline Meryta angustifolia & no phylogeny found & - \\
\hline Meryta latifolia & Perrie \& Shepherd 2009 & Meryta denhamii \\
\hline Myoporum obscurum & no phylogeny found & - \\
\hline Myrsine ralstoniae & no phylogeny found & - \\
\hline Pennantia endlicheri & $\begin{array}{l}\text { Keeling, Gardner \& de Lange } \\
2004\end{array}$ & Pennantia corymbosa \\
\hline Phreatia limenophylax & no phylogeny found & - \\
\hline Pittosporum bracteolatum & Carrodus 2009 & Pittosporum umbellatum \\
\hline Pteris kingiana & Chao, Moore \& Ladle, 2014 & Pteris tremula \\
\hline Pteris zahlbruckneriana & no phylogeny found & - \\
\hline Senecio australis & Liew et al. 2018 & Senecio minimus \\
\hline Senecio evansianus & no phylogeny found & - \\
\hline Senecio hooglandia & Liew et al. 2018 & - \\
\hline Streblorrhiza speciosa & no phylogeny found & - \\
\hline Taeniophyllum norfolianum & no phylogeny found & - \\
\hline Thelychiton brachypus & no phylogeny found & - \\
\hline Tmesipteris norfolkensis & no phylogeny found & - \\
\hline
\end{tabular}




\begin{tabular}{lll}
\hline Ungeria floribunda & no phylogeny found & - \\
\hline Wikstroemia australis & no phylogeny found & - \\
\hline
\end{tabular}

TableA10 Snares Island species checklist

\begin{tabular}{lll}
\hline Snares endemic taxa & Avaliable phylogeny & Closest extant mainland relative \\
\hline Anisotoma acutifolia & no phylogeny available & - \\
\hline Stilbocarpa robusta & Mitchell et al. 1999 & - \\
\hline
\end{tabular}

TableA11 Stewart Island species checklist

\begin{tabular}{lll}
\hline Stewart endemic taxa & Avaliable phylogeny & Closest extant mainland relative \\
\hline Aciphylla cartilaginea & no phylogeny found & - \\
\hline Aciphylla stannensis & no phylogeny found & $=$ \\
\hline Aciphylla traillii & Radford, Watson \& Preston & - \\
& 2001 & \\
\hline Bulbinella gibbsii var. gibbsii & no phylogeny found & - \\
\hline Celmisia clavata & no phylogeny found & $=$ \\
\hline Chionochloa lanea & no phylogeny found & $=$ \\
\hline Gentianella gibbsii & no phylogeny found & $=$ \\
\hline Gingidia flabellate & no phylogeny found & $=$ \\
\hline Leptinella traillii subsp. traillii & no phylogeny found & $=$ \\
\hline Poa aucklandica subsp. rakiura & no phylogeny found & $=$ \\
\hline Ranunculus kirkii & no phylogeny found & $=$ \\
\hline Ranunculus stylosus & no phylogeny found & $=$ \\
\hline Ranunculus viridis & Lehnebach 2008 & $=$ \\
\hline Raoulia goyenii & Smissen, Breitwieser, Ward, & Raoulia buchananii \\
\hline
\end{tabular}

TableA12 Three Kings Island species checklist

\begin{tabular}{lll}
\hline Three Kings endemic taxa & Avaliable phylogeny & Closest extant mainland relative \\
\hline $\begin{array}{l}\text { Alectryon excelsus subsp. } \\
\text { grandis }\end{array}$ & Edwards \& Gadek 2000 & Alectryon excelsus \\
\hline Brachyglottis arborescens & Wagstaff \& Breiywieser 2004 & Brachyglottis repanda \\
\hline Carex elingamita & Heenan et al. 2010 & - \\
\hline Coprosma macrocarpa & Papadopulos et al. 2011 & - \\
\hline Cordyline obtecta & no phylogeny found & - \\
\hline Davallia tasmanii subsp. & no phylogeny found & - \\
tasmanii & & - \\
\hline Elingamita johnsonii & Stöckler 2001 & - \\
\hline Kunzea triregensis & no phylogeny found & - \\
\hline Meryta sinclairii & no phylogeny found & - \\
\hline Myrsine oliveri & Papadopulos et al. 2011 & - \\
\hline Pennantia baylisiana & Keeling et al. 2004 & - \\
\hline Pimelea telura & no phylogeny found & - \\
\hline Piper melchior & no phylogeny found & - \\
\hline Pittosporum fairchil & no phylogeny found & - \\
\hline Streblus smithii & no phylogeny found & - \\
\hline Tecomanthe speciose & no phylogeny found & - \\
\hline Veronica insularis & Dirk et al. 2004 & - \\
\hline
\end{tabular}




\section{Suitable versus unsuitable phylogenies}

\section{Phylogeny Example A}

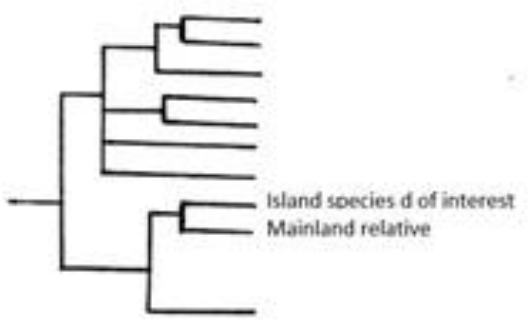

Phylogeny Example X

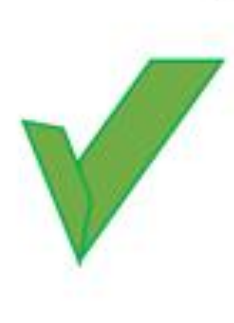

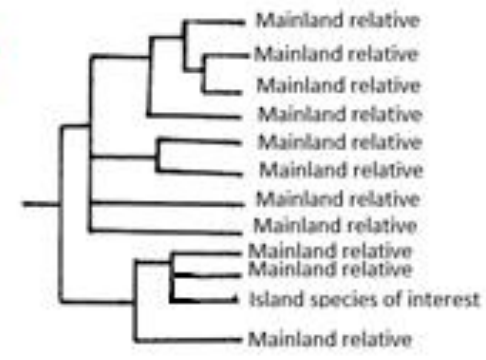

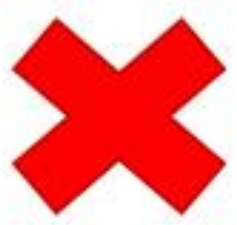

Phylogeny Example B

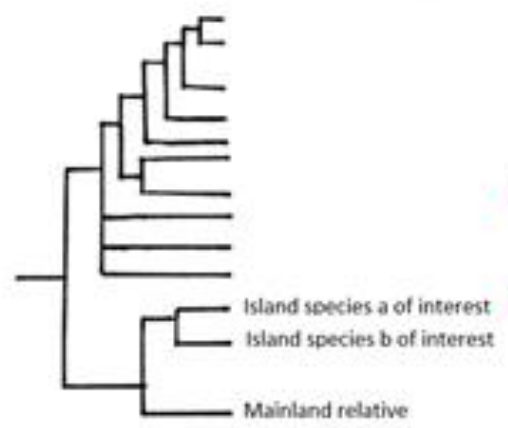

Phylogeny Example $Y$
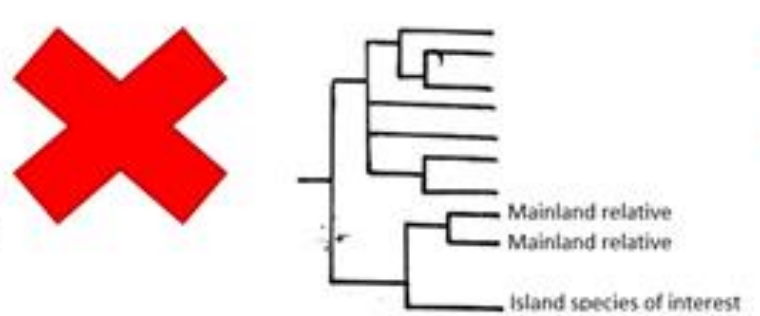

Figure A1 Suitable versus unsuitable phylogenies

In Phylogeny Example A, the Island species of interest (d) is in a position where there is only one mainland relative. In this example. This demonstrates a suitable phylogeny that could be used for this thesis. This methodology relies heavily on fundamental assumptions, see discussion for more on this topic. In Phylogeny Example $X$ the Island species of interest is not clearly in a clade with one mainland species. Here it is equally related to all 7 members of the clade it is in. With each of those members having a locality bigger than the Island species. In this instance it is not possible to ascertain which of the phylogenetic relationships are most likely, therefore without 1 clear extant mainland relative, this island species is not able to be used in the study. In Phylogeny Example Y, similar to Phylogeny Example $X$ it is not possible to ascertain which of the mainland species are more closely related to the island species, therefore a 'species pair' is unable to be made, and this Island species too is unable to be a part of the study. Phylogeny Example B shows a similar reasoning to Phylogeny Example $A$, in that Island species $\mathrm{a}$ and $\mathrm{b}$ (both from the same island) are related to 1 mainland relative. However, for the purposes of this thesis, it is not possible to disentangle interspecific changes in the island species versus the island/ mainland change if both island species were kept. Averaging the island species also might not give a true representation of the original island founder population before it spilt into two island species. In this instance this phylogeny is also unsuitable for the study and cannot be used. 


\section{Taxomic order breakdown per island of all endemic species}

TableA13 Endemic species frequency grouped by taxonomic order and island

\begin{tabular}{|c|c|c|c|c|c|c|c|c|c|c|c|c|c|}
\hline & AN & $A U$ & BO & $\mathrm{CP}$ & $\mathrm{CH}$ & KD & LH & MQ & NO & SN & SW & TK & Total \\
\hline Apiales & - & - & - & - & 3 & 1 & 2 & 1 & 4 & 1 & 4 & 3 & 19 \\
\hline Arecales & - & - & - & - & - & 1 & 4 & - & - & - & - & - & 5 \\
\hline Asparagales & - & - & - & - & 1 & - & 4 & 2 & 5 & - & 1 & 1 & 14 \\
\hline Asterales & 1 & 1 & - & 1 & 9 & 3 & 11 & - & 3 & - & 3 & 1 & 33 \\
\hline Boraginales & - & - & - & - & 1 & - & - & - & - & - & - & - & 1 \\
\hline Brassicales & - & 2 & 1 & 2 & 3 & 1 & 2 & - & - & - & - & - & 11 \\
\hline Canellales & - & - & - & - & - & - & 1 & - & - & - & - & - & 1 \\
\hline Caryophyllales & 1 & - & - & - & 1 & 1 & 1 & - & 2 & - & - & - & 6 \\
\hline Chloranthales & - & - & - & - & - & 1 & - & - & - & - & - & - & 1 \\
\hline Cucurbitales & - & - & - & - & - & 1 & - & - & - & - & - & - & 1 \\
\hline Cyatheales & - & - & - & - & - & 2 & 4 & - & 2 & - & - & - & 8 \\
\hline Ericales & - & - & - & - & 4 & 1 & 5 & - & 1 & - & - & 2 & 13 \\
\hline Fabales & - & - & - & - & - & - & 2 & - & 1 & - & - & - & 3 \\
\hline Gentianales & 1 & 2 & - & 2 & 3 & 2 & 13 & - & 2 & 1 & 1 & 1 & 28 \\
\hline Geraniales & - & - & - & - & 1 & - & - & - & - & - & - & - & 1 \\
\hline Hymenophyllales & - & - & - & - & - & - & 3 & - & - & - & - & - & 3 \\
\hline Lamiales & - & 3 & - & - & 3 & 2 & 6 & - & 1 & - & - & 2 & 17 \\
\hline Laurales & - & - & - & - & - & - & 1 & - & - & - & - & - & 1 \\
\hline Malpighiales & - & - & - & - & 2 & 1 & 5 & - & 3 & - & - & - & 11 \\
\hline Malvales & - & - & - & - & 1 & - & 1 & - & 4 & - & - & 1 & 7 \\
\hline Marattiales & - & - & - & - & - & - & 1 & - & - & - & - & - & 1 \\
\hline Myrtales & 1 & - & - & - & - & 1 & 5 & - & - & - & - & 1 & 8 \\
\hline Osmundales & - & - & - & - & - & - & 1 & - & - & - & - & - & 1 \\
\hline Oxalidales & - & - & - & - & - & - & 1 & - & - & - & - & - & 1 \\
\hline Pandanales & - & - & - & - & - & - & 1 & - & - & - & - & - & 1 \\
\hline Pinales & - & - & - & - & - & - & - & - & 1 & - & - & - & 1 \\
\hline Piperales & - & - & - & - & - & - & 1 & - & - & - & - & 1 & 2 \\
\hline Poales & 1 & 1 & - & 1 & 7 & 4 & 4 & 1 & 2 & - & 2 & 1 & 24 \\
\hline Polypodiales & - & - & - & - & 1 & 2 & 17 & - & 4 & - & - & 1 & 25 \\
\hline Psilotales & - & - & - & - & - & - & - & - & 1 & - & - & - & 1 \\
\hline Ranunculales & - & - & - & - & - & - & 1 & - & 1 & - & 3 & - & 5 \\
\hline Rosales & - & 1 & - & - & - & 1 & 5 & - & 2 & - & - & 1 & 10 \\
\hline Santalales & - & - & - & - & - & - & 2 & - & 1 & - & - & - & 3 \\
\hline Sapindales & - & - & - & - & - & - & 4 & - & 1 & - & - & 1 & 6 \\
\hline Saxifragales & - & - & - & - & - & - & 1 & - & - & - & - & - & 1 \\
\hline Species Total & 5 & 10 & 1 & 6 & 40 & 25 & 109 & 4 & 41 & 2 & 14 & 17 & 274 \\
\hline
\end{tabular}

$\mathrm{AN}=$ Antipodes, $\mathrm{AU}=$ Auckland, $\mathrm{BO}=$ Bounty, $\mathrm{CH}=$ Chathams, $\mathrm{KD}=$ Kermadec, $\mathrm{LH}=$ Lord Howe, $\mathrm{MQ}=$ Macquarie, $\mathrm{NO}=$ Norfolk, $\mathrm{SN}=$ Snares, $\mathrm{SW}=$ Stewart, $\mathrm{TK}=$ Three Kings 


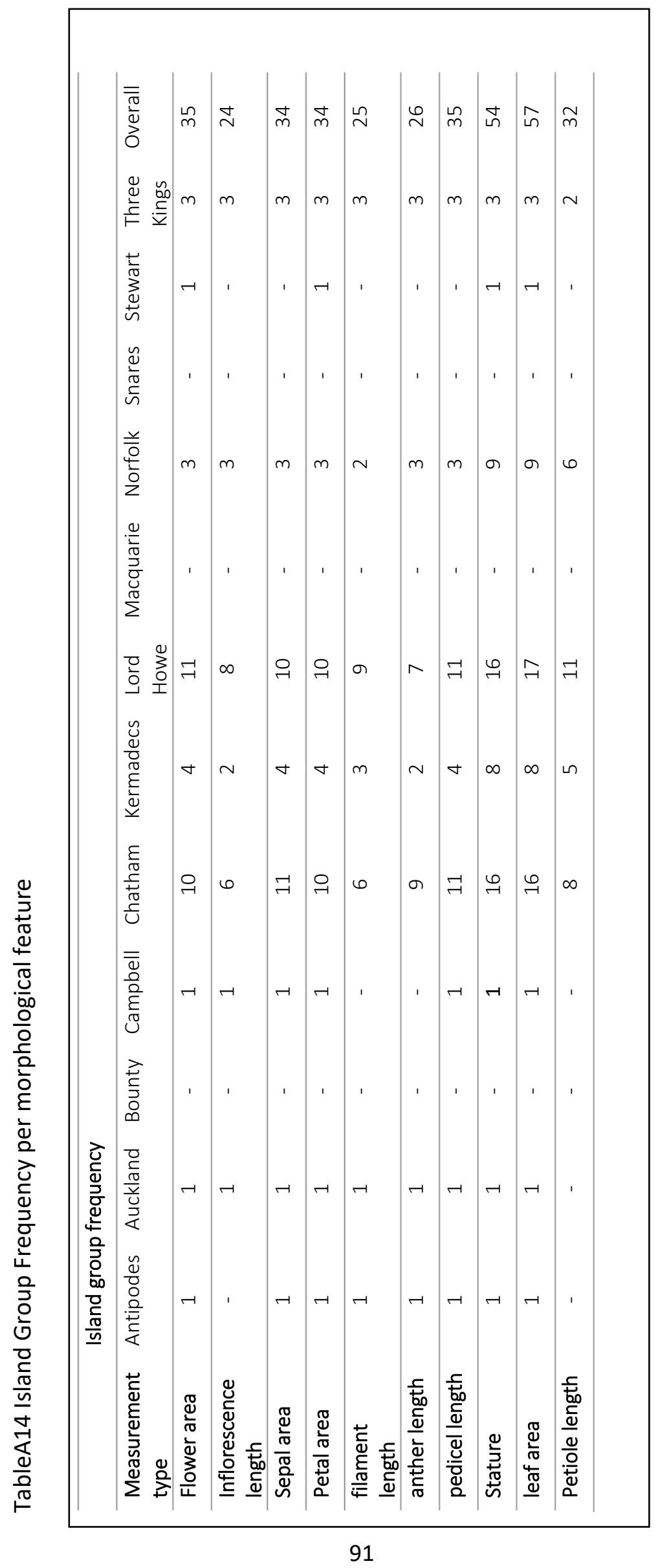




\title{
Appendix B: Chapter 2 Supplementary material
}

\author{
Analysis of different factors
}

Table B1 Analysis of Island Rule in floral features across Latitude

\begin{tabular}{lcccc}
\hline Morphological feature & t value & p value & R squared & F statistic \\
Flower area & -0.06 & 0.95 & 0.004 & $3.9 \mathrm{e}^{-3}$ on 1 \& 33 DF \\
Inflorescence length & 2.47 & $0.02 *$ & 0.22 & 6.12 on 1 \& 22 DF \\
Petal area & 0.49 & 0.63 & 0.008 & 0.24 on 1 \& 32 DF \\
Sepal area & 0.18 & 0.86 & 0.001 & 0.03 on 1 \& 30 DF \\
Filament length & 0.64 & 0.53 & 0.02 & 0.41 on 1 \& 23 DF \\
Anther length & 0.64 & 0.53 & 0.02 & 0.40 on 1 \& 24 DF \\
Pedicel length & -1.27 & 0.95 & 0.05 & $3.4 \mathrm{e}^{-3}$ on 1 \& 33 DF \\
\hline
\end{tabular}

\section{Different analysis factors}

\begin{tabular}{|c|c|}
\hline Factor & Description \\
\hline island & $\begin{array}{l}\text { The island of origin for an insular endemic species. Any large discrepencies as a } \\
\text { result of island may indicate environmental differences. }\end{array}$ \\
\hline measure & Where the measurements came from. Either herbaria or a floral description \\
\hline endemic & $\begin{array}{l}\text { The total number of endemic plant species in total from the given island of } \\
\text { occurence }\end{array}$ \\
\hline order & $\begin{array}{l}\text { The total number of endemic plant species within the same taxonomic order } \\
\text { from the same island of occurence }\end{array}$ \\
\hline type & The generic type of plant (e.g. shrub, tree, herb) \\
\hline Orderz & $\begin{array}{l}\text { The taxonomic order of a plant. This factor indicates if there are tendancies of } \\
\text { the lineage to display certain characterisitics, regardless of the plant } \\
\text { posisiotning in the landscape }\end{array}$ \\
\hline rainfall & Annual average rainfall of the island (measured in $\mathrm{mm}$ ) \\
\hline temp & Annual average temperature of the island (measured in Celcisus) \\
\hline wind & Annual average windspeed ( $\mathrm{km} / \mathrm{hr})$ \\
\hline size & Size of the island (measured in $\mathrm{km}^{2}$ ) \\
\hline
\end{tabular}

Table B2 Analysis of Island Rule in Filament length against different factors

\begin{tabular}{lcccc}
\hline & T value & P value & F stat & R squared \\
\hline island & 1.49 & 0.37 & 1.16 on 6 \& 18 DF & 0.28 (Adjusted 0.04) \\
\hline measure & 0.55 & 0.59 & 0.29 on 1 \& 23 DF & 0.01 (Adjusted -0.03) \\
\hline endemic & -0.64 & 0.53 & 0.41 on 1 \& 23 Df & 0.02 (Adjusted -0.03) \\
\hline order & 1.53 & 0.14 & 2.35 on 1 \& 23 DF & 0.7 (Adjusted 0.5) \\
\hline type & -2.99 & 0.89 & 0.33 on 5 \& 19 DF & 0.08 (Adjusted -0.16) \\
\hline Orderz & 0.21 & 0.77 & 0.63 on 10 \& 14 DF & 0.31 (Adjusted -0.18) \\
\hline rainfall & -0.89 & 0.38 & 0.791 \& 23 DF & 0.03 (Adjusted-0.008) \\
\hline temp & -0.77 & 0.45 & 0.60 on 1 \& 23 DF & 0.03 (Adjusted -0.02 ) \\
\hline wind & 0.23 & 0.82 & 0.05 on 1 \& 23 DF & 0.002 (Adjusted -0.04) \\
\hline size & 1.31 & 0.20 & 1.71 on 1 \& 23 DF & 0.07 (adjusted 0.03) \\
\hline
\end{tabular}


Table B3 Analysis of Island Rule in Petal area against different factors

\begin{tabular}{lcccc}
\hline & T value & P value & F stat & R squared \\
\hline island & 16.65 & $0.02^{*}$ & 2.77 on 8 \& 25 DF & 0.47 (Adjusted 0.29) \\
\hline measure & 1.73 & 0.09 & 2.99 on 1 \& 32 DF & 0.09 (Adjusted 0.06) \\
\hline endemic & -1.81 & 0.08 & 3.29 on 1 \& 32 DF & 0.09 (Adjusted 0.06) \\
\hline order & -0.12 & 0.90 & 0.02 on 1 \& 32 DF & $4.7 x \mathrm{e}^{-4}$ (Adjusted -0.03) \\
\hline type & -0.89 & 0.74 & 0.55 on 5 \& 28 DF & 0.09 (Adjusted -0.07$)$ \\
\hline Orderz & -4.14 & 0.19 & 1.54 on 11 \& 22 DF & 0.44 (Adjusted 0.15) \\
\hline rainfall & -0.74 & 0.46 & 0.55 on 1 \& 32 DF & 0.02 (Adjusted -0.01$)$ \\
\hline temp & -0.83 & 0.41 & 0.69 on 1 \& 32 DF & 0.02 (Adjusted -0.01$)$ \\
\hline wind & -2.73 & $0.01^{*}$ & 7.44 on 1 \&32 DF & 0.19 (Adjusted 0.16) \\
\hline size & 2.86 & $0.01^{*}$ & 8.20 on 1 \& 32 DF & 0.20 (adjusted 0.18) \\
\hline
\end{tabular}

Table B4 Analysis of Island Rule in Sepal area against different factors

\begin{tabular}{lcccc}
\hline & T value & P value & \multicolumn{1}{l}{ F stat } & R squared \\
\hline island & 4.78 & 0.49 & 0.92 on 6 \& 26 DF & 0.17 (Adjusted -0.02) \\
\hline measure & 0.82 & 0.42 & 0.68 on 1 \& 31 DF & 0.02 (Adjusted -0.01) \\
\hline endemic & -1.53 & 0.14 & 2.32 on 1 \& 31 DF & 0.07 (Adjusted 0.04) \\
\hline order & 0.69 & 0.49 & 0.47 on 1 \& 31 DF & 0.01 (Adjusted -0.02) \\
\hline type & -5.31 & 0.29 & 1.32 on 5 \& 27 DF & 0.19 (Adjusted 0.05) \\
\hline Orderz & -5.25 & 0.10 & 1.91 on 11 \& 21 DF & 0.5 (Adjusted 0.24) \\
\hline rainfall & -1.57 & 0.13 & 2.47 on 1 \& 31 DF & 0.07 (Adjusted 0.04) \\
\hline temp & -0.69 & 0.49 & 0.48 on 1 \& 31 DF & 0.02 (Adjusted -0.02) \\
\hline wind & -2.04 & 0.05 & 4.18 on 1 \& 31 DF & 0.12 (Adjusted 0.09) \\
\hline size & 0.96 & 0.35 & 0.92 on 1 \& 31 DF & 0.03 (Adjusted -0.003) \\
\hline
\end{tabular}

Table B5 Analysis of Island Rule in Anther length against different factors

\begin{tabular}{lcccc}
\hline & T value & P value & F stat & R squared \\
\hline island & 1.79 & 0.20 & 1.59 on 6 \& 19 DF & 0.33 (Adjusted 0.12) \\
\hline measure & -0.85 & 0.41 & 0.72 on 1 \& 24 DF & 0.03 (Adjusted -0.01) \\
\hline endemic & -0.23 & 0.82 & 0.05 on 1 \& 24 DF & $2.2 \times e^{-3}$ (Adjusted -0.04) \\
\hline order & 0.52 & 0.61 & 0.26 on 1 \& 24 DF & 0.01 (Adjusted -0.03) \\
\hline type & 2.66 & 0.79 & 0.51 on 6 \& 19 DF & 0.14 (Adjusted -0.13) \\
\hline Orderz & 12.14 & 0.07 & 2.31 on 11 \& 14 DF & 0.65 (Adjusted 0.07) \\
\hline rainfall & -0.94 & 0.36 & 0.88 on 1 \& 24 DF & 0.04 (Adjusted -0.005$)$ \\
\hline temp & -0.38 & 0.71 & 0.14 on 1 \& 24 DF & 0.006 (Adjusted -0.04$)$ \\
\hline wind & -0.93 & 0.36 & 0.86 on 1 \& 24 DF & 0.03 (Adjusted -0.006) \\
\hline size & 0.65 & 0.95 & 0.004 on 1 \& 24 DF & 0.0002 (Adjusted -0.04) \\
\hline
\end{tabular}


Table B6 Analysis of Island Rule in Inflorescence length against different factors

\begin{tabular}{lcccr}
\hline & T value & P value & \multicolumn{1}{l}{ F stat } & \multicolumn{1}{l}{ R squared } \\
\hline island & -16.67 & $0.03^{*}$ & 3.06 on 6 \& 17 DF & 0.52 (Adjusted 0.35) \\
\hline measure & 1.52 & 0.14 & 2.31 on 1 \& 22 DF & 0.09 (Adjusted 0.05) \\
\hline endemic & -1.47 & 0.16 & 2.16 on 1 \& 22 DF & 0.09 (Adjusted 0.05) \\
\hline order & 0.1 & 0.92 & 0.01 on 1 \& 22 DF & 4.2 e $^{-4}$ (Adjusted -0.05$)$ \\
\hline type & -0.7 & 0.95 & 0.21 on 5 \& 18 DF & 0.06 (Adjusted -0.21 ) \\
\hline Orderz & -4.88 & 0.41 & 1.13 on 9 \& 14 DF & 0.42 (Adjusted 0.05) \\
\hline rainfall & -2.17 & $0.04^{*}$ & 4.71 on 1 \& 22 DF & 0.18 (Adjusted 0.14) \\
\hline temp & -1.42 & 0.17 & 2.02 on 1 \& 22 DF & 0.08 (Adjusted 0.04) \\
\hline wind & -0.11 & 0.91 & 0.01 on 1 \& 22 DF & 0.0006 (Adjusted -0.004) \\
\hline size & 2.75 & $0.01 *$ & 7.59 on 1 \& 22 DF & 0.26 (Adjusted 0.22) \\
\hline
\end{tabular}

Table B7 Analysis of Island Rule in Flower size against different factors

\begin{tabular}{lcccc}
\hline & T value & P value & F stat & R squared \\
\hline island & 5.6 & $0.01^{*}$ & 3.19 on 8 \& 26 DF & 0.49 (Adjusted 0.34) \\
\hline measure & -0.67 & 0.51 & 0.45 on 1 \& 33 DF & 0.01 (Adjusted 0.02 ) \\
\hline endemic & -0.95 & 0.35 & 0.89 on 1 \& 33 DF & 0.03 (Adjusted 3.0xe-3) \\
\hline order & 0.69 & 0.49 & 0.49 on 1 \& 33 DF & 0.01 (Adjusted -0.02 ) \\
\hline type & -0.73 & 0.74 & 0.54 on 5 \& 29 DF & 0.09 (Adjusted -0.07 ) \\
\hline Orderz & -2.36 & 0.29 & 1.29 on 13 \& 21 DF & 0.45 (Adjusted 0.1) \\
\hline rainfall & -2.26 & $0.03^{*}$ & 5.12 on 1 \& 33 DF & 0.13 (Adjusted 0.11) \\
\hline temp & -0.49 & 0.63 & 0.24 on 1 \& 33 DF & 0.007 (Adjusted -0.02 ) \\
\hline wind & -3.15 & $0.003^{*}$ & 9.91 on 1 \& 33 DF & 0.23 (Adjusted 0.21) \\
\hline size & 1.81 & 0.08 & 3.28 on 1 \& 33 DF & 0.09 (Adjusted 0.06)
\end{tabular}

Table B8 Analysis of Island Rule in Pedicel length against different factors

\begin{tabular}{|c|c|c|c|c|}
\hline & T value & $P$ value & F stat & R squared \\
\hline island & 1.48 & 0.17 & 1.64 on $7 \& 27$ DF & 0.29 (Adjusted 0.12) \\
\hline measure & 1.49 & 0.14 & 2.24 on $1 \& 33$ DF & 0.06 (Adjusted 0.04) \\
\hline endemic & 0.65 & 0.52 & 0.42 on $1 \& 33$ DF & 0.01 (Adjusted -0.02) \\
\hline order & -0.96 & 0.45 & 0.91 on $1 \& 33$ DF & 0.03 (Adjusted -2.6xe ${ }^{-3}$ ) \\
\hline type & 2.67 & 0.44 & 0.99 on $5 \& 25 \mathrm{DF}$ & 0.15 (Adjusted -1.9xe ${ }^{-3}$ ) \\
\hline Orderz & 0.56 & 0.48 & 0.99 on $12 \& 22 \mathrm{DF}$ & 0.35 (Adjusted 9.1xe ${ }^{-4}$ ) \\
\hline rainfall & 0.02 & 0.98 & 0.0006 on $1 \& 33 \mathrm{DF}$ & $1.7 e^{\wedge}-5$ (Adjusted -0.03$)$ \\
\hline temp & 1.73 & 0.09 & 2.99 on $1 \& 33$ DF & 0.08 (Adjusted 0.06) \\
\hline wind & -0.34 & 0.73 & 0.12 on $1 \& 33$ DF & 0.004 (Adjusted -0.03) \\
\hline size & -2.37 & $0.02 *$ & 5.63 on $1 \& 33$ DF & 0.15 (Adjusted 0.12) \\
\hline
\end{tabular}


Supplementary graphs
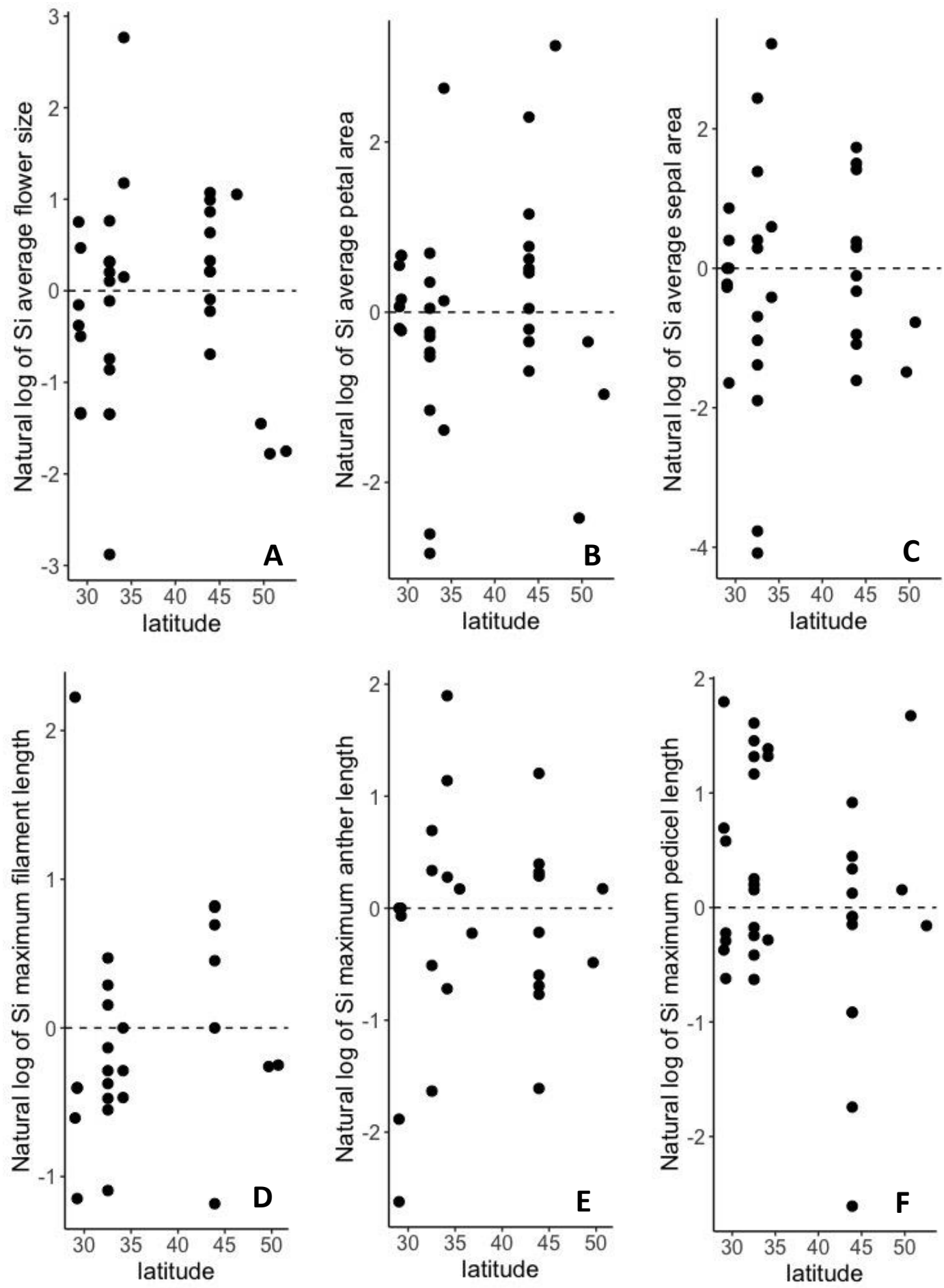

Figure B1 Non-significant graphic results of latitude for floral features: (flower area (A), petal area (B), sepal area (C), filament length (D), anther length $(E)$, and pedicel length $(F)$ ). All measurement data is natural logged. The dashed lined represented the line of isometry, where Island values = mainland values. See Appendix B for test statistic values. Latitude is measured in 'Decimal degrees'. 


\section{Species composition and measurement type and reference for floral features}

Table B9 Flower area dataset measurements and measurement references

\begin{tabular}{|c|c|c|c|c|c|c|}
\hline $\begin{array}{l}\text { measurement } \\
\text { type }\end{array}$ & island species & $\begin{array}{l}\text { island } \\
\text { flower } \\
\text { area }\left(\mathrm{cm}^{2}\right)\end{array}$ & Reference(s) & $\begin{array}{l}\text { Mainland } \\
\text { relative }\end{array}$ & $\begin{array}{l}\text { mainland } \\
\text { flower area } \\
\left(\mathrm{cm}^{2}\right)\end{array}$ & Reference(s) \\
\hline herbarium & $\begin{array}{l}\text { Abrotanella } \\
\text { rosulata }\end{array}$ & 0.067 & SP102466 & $\begin{array}{l}\text { Abrotanella } \\
\text { spathulata }\end{array}$ & 0.38 & SP57761 \\
\hline herbarium & $\begin{array}{l}\text { Alectryon excelsus } \\
\text { grandis }\end{array}$ & 0.63 & $\begin{array}{l}\text { deLange, } \\
\text { Cameron, \& } \\
\text { Murray, } 1999\end{array}$ & $\begin{array}{l}\text { Alectryon } \\
\text { excelsus } \\
\text { excelsus }\end{array}$ & 0.03 & AK163401 \\
\hline herbarium & Alyxia squamulosa & 0.48 & $\begin{array}{l}\text { Mel223111, } \\
\text { MEL223108 }\end{array}$ & $\begin{array}{l}\text { Alyxia } \\
\text { reinwardtii }\end{array}$ & 0.39 & H570/97 50 \\
\hline herbarium & $\begin{array}{l}\text { Brachyglottis } \\
\text { arborescens }\end{array}$ & 0.17 & $\begin{array}{l}\text { SP78892 } \\
\text { SP14292 }\end{array}$ & $\begin{array}{l}\text { Brachyglottis } \\
\text { repanda }\end{array}$ & 0.14 & SP58743 \\
\hline flora & Brachyglottis huntii & 1.34 & NZFLORA & $\begin{array}{l}\text { Brachyglottis } \\
\text { stewartiae }\end{array}$ & 0.97 & NZFLORA \\
\hline herbarium & Carmichaelia exsul & 0.19 & MEL2120317 & $\begin{array}{l}\text { Carmichaelia } \\
\text { williamsii }\end{array}$ & 3.49 & K000950929 \\
\hline herbarium & $\begin{array}{l}\text { Corokia } \\
\text { macrocarpa }\end{array}$ & 0.23 & AK6736 & $\begin{array}{l}\text { Corokia } \\
\text { cotoneaster }\end{array}$ & 0.12 & $\begin{array}{l}\text { P01900002, } \\
\text { BR0000005948567 }\end{array}$ \\
\hline herbarium & $\begin{array}{l}\text { Cryptocarya } \\
\text { gregsonii }\end{array}$ & 0.25 & $\begin{array}{l}\text { NSW524068, } \\
\text { NSW524032 } \\
\text { confirmed with } \\
\text { Hutton, 2002, and } \\
\text { Australian Flora } \\
\text { book vol } 49\end{array}$ & $\begin{array}{l}\text { Cryptocarya } \\
\text { densiflora }\end{array}$ & 0.23 & GH00041368 \\
\hline herbarium & $\begin{array}{l}\text { Dendrobium } \\
\text { moorei }\end{array}$ & 0.85 & $\begin{array}{l}\text { K001085451 } \\
\text { K001085449 }\end{array}$ & $\begin{array}{l}\text { Dendrobium } \\
\text { kingianum }\end{array}$ & 2.02 & K001085439 \\
\hline flora & $\begin{array}{l}\text { Gentianella } \\
\text { antipoda }\end{array}$ & 0.32 & NZFLORA & $\begin{array}{l}\text { Gentianella } \\
\text { cerina }\end{array}$ & 1.37 & NZFLORA \\
\hline herbarium & $\begin{array}{l}\text { Gentianella } \\
\text { chathamica subsp. } \\
\text { Chathamica }\end{array}$ & 1.56 & $\begin{array}{l}\text { SP003354, } \\
\text { SP091523 (A) }\end{array}$ & $\begin{array}{l}\text { Gentianella } \\
\text { saxosa }\end{array}$ & 1.72 & SP47560, SP47517 \\
\hline herbarium & Lepidium oblitum & 0.02 & CHR 5523033 & $\begin{array}{l}\text { Lepidium } \\
\text { obtusatum }\end{array}$ & 0.03 & K000642772 \\
\hline herbarium & $\begin{array}{l}\text { Leptecophylla } \\
\text { robusta }\end{array}$ & 0.07 & $\begin{array}{l}\text { SP055221, } \\
\text { SP018176 }\end{array}$ & $\begin{array}{l}\text { Leptecophylla } \\
\text { juniperina }\end{array}$ & 0.06 & SP55449 \\
\hline herbarium & $\begin{array}{l}\text { Leptinella } \\
\text { featherstonii }\end{array}$ & 0.51 & MEL42209 & $\begin{array}{l}\text { Leptinella } \\
\text { serrulata }\end{array}$ & 0.22 & SP091212 \\
\hline herbarium & $\begin{array}{l}\text { Melaleuca } \\
\text { howeana }\end{array}$ & 0.06 & NSW365338 & $\begin{array}{l}\text { Melaleuca } \\
\text { ericifolia }\end{array}$ & 0.04 & B-W 14365-020 \\
\hline herbarium & $\begin{array}{l}\text { Melicope } \\
\text { polybotrya }\end{array}$ & 0.15 & $\begin{array}{l}\text { L2124202, } \\
\text { L2124201, } \\
\text { L2124203, } \\
\text { P05184454, } \\
\text { K000717407 }\end{array}$ & $\begin{array}{l}\text { Sacromelicope } \\
\text { simpliciafolia }\end{array}$ & 0.12 & $\begin{array}{l}\text { P00222344, } \\
\text { P05214419 }\end{array}$ \\
\hline herbarium & $\begin{array}{l}\text { Melicytus novae- } \\
\text { zelandia subsp. } \\
\text { centurionis }\end{array}$ & 0.19 & $\begin{array}{l}\text { SP029562 } \\
\text { SP029543 } \\
\text { SP029550 } \\
\text { SP067867 } \\
\text { SP085716 }\end{array}$ & $\begin{array}{l}\text { Melicytus } \\
\text { novae-zelandia } \\
\text { subsp. novae- } \\
\text { zelandiae }\end{array}$ & 0.42 & SP092870 \\
\hline herbarium & $\begin{array}{l}\text { Metrosideros } \\
\text { kermadecensis }\end{array}$ & 0.84 & $\begin{array}{l}\text { SP095393, } \\
\text { SP088606 }\end{array}$ & $\begin{array}{l}\text { Metrosideros } \\
\text { excelsa }\end{array}$ & 3.23 & SP023044 \\
\hline herbarium & $\begin{array}{l}\text { Myosotidium } \\
\text { hortensia }\end{array}$ & 0.23 & K001067060 & $\begin{array}{l}\text { Cynoglossum } \\
\text { paniculatum }\end{array}$ & 0.08 & K000573727 \\
\hline flora & $\begin{array}{l}\text { Myrsine } \\
\text { chathamica }\end{array}$ & 0.07 & nzcpn, nzflora & $\begin{array}{l}\text { Myrsine } \\
\text { aquilonia }\end{array}$ & 0.13 & nzcpn \\
\hline herbarium & $\begin{array}{l}\text { Negria } \\
\text { rhabdothamusides }\end{array}$ & 7.25 & $\begin{array}{l}\text { K000831478, } \\
\text { NSW402620, }\end{array}$ & $\begin{array}{l}\text { Lenbrassia } \\
\text { australiana }\end{array}$ & 2.16 & $\begin{array}{l}\text { L2819235, } \\
\text { 00453906, }\end{array}$ \\
\hline
\end{tabular}


Appendices - Appendix B

\begin{tabular}{|c|c|c|c|c|c|c|}
\hline & & & $\begin{array}{l}\text { E00642060, } \\
\text { P03851834 }\end{array}$ & & & $\begin{array}{l}\text { L3793925, } \\
\text { L2819233 }\end{array}$ \\
\hline herbarium & Olearia mooneyi & 0.16 & K000838921 & $\begin{array}{l}\text { Olearia } \\
\text { argophylla }\end{array}$ & 0.63 & P00711258 \\
\hline herbarium & $\begin{array}{l}\text { Pennantia } \\
\text { endlicheri }\end{array}$ & 0.15 & L0014946 & $\begin{array}{l}\text { Pennantia } \\
\text { corymbosa }\end{array}$ & 0.063 & $\begin{array}{l}\text { SP086322, } \\
\text { SP08611, SP083238 }\end{array}$ \\
\hline herbarium & $\begin{array}{l}\text { Pittosporum } \\
\text { bracteolatum }\end{array}$ & 1.32 & SP084276 & $\begin{array}{l}\text { Pittosporum } \\
\text { umbellatum }\end{array}$ & 0.63 & TCD0010024 \\
\hline herbarium & $\begin{array}{l}\text { Plantago } \\
\text { aucklandica }\end{array}$ & 0.033 & K000438784 & $\begin{array}{l}\text { Plantago } \\
\text { lanigera }\end{array}$ & 0.19 & $\begin{array}{l}\text { SP104833/A, } \\
\text { SP089135 }\end{array}$ \\
\hline flora & Plectorrhiza erecta & 0.1 & $\begin{array}{l}\text { Hutton 2002, } \\
\text { Dockrill } 1967\end{array}$ & $\begin{array}{l}\text { Plectorrhiza } \\
\text { tridentata }\end{array}$ & 0.39 & $\begin{array}{l}\text { Australian Tropical } \\
\text { Rainforest Orchids }\end{array}$ \\
\hline herbarium & $\begin{array}{l}\text { Pseudopanax } \\
\text { chathamicus }\end{array}$ & 0.26 & SP3307, SP25031 & $\begin{array}{l}\text { Pseudopanax } \\
\text { crassifolius }\end{array}$ & 0.09 & $\begin{array}{l}\text { AK6183, SP022836, } \\
\text { SP099142, } \\
\text { SP078845, } \\
\text { BR0000005785070 }\end{array}$ \\
\hline herbarium & $\begin{array}{l}\text { Pseudopanax } \\
\text { kermadecensis }\end{array}$ & 0.13 & SP05341 & $\begin{array}{l}\text { Pseudopanax } \\
\text { arboreus }\end{array}$ & 0.49 & SP54311 \\
\hline herbarium & Raoulia goyenii & 0.1 & AK247246 & $\begin{array}{l}\text { Raoulia } \\
\text { buchananii }\end{array}$ & 0.03 & AK121993 \\
\hline herbarium & Senecio australis & 0.41 & SP82400 & Senecio minimus & 0.48 & AK347668 \\
\hline herbarium & $\begin{array}{l}\text { Senecio } \\
\text { kermadecensis }\end{array}$ & 0.25 & $\begin{array}{l}\text { SP90180, } \\
\text { SP31463 }\end{array}$ & Senecio hauwai & 0.42 & CHR $201160 \mathrm{~A}$ \\
\hline herbarium & $\begin{array}{l}\text { Sonchus } \\
\text { grandifolius }\end{array}$ & 3 & $\begin{array}{l}\text { SP27962, } \\
\text { SP27948 }\end{array}$ & $\begin{array}{l}\text { Sonchus novae- } \\
\text { zelandiae }\end{array}$ & 6 & K000323043 \\
\hline herbarium & Sonchus kirkii & 2.02 & $\begin{array}{l}\text { NSW135787, } \\
\text { confirmed by } \\
\text { Allan } 1982\end{array}$ & $\begin{array}{l}\text { Sonchus } \\
\text { oleraceus }\end{array}$ & 1.26 & AK304834 \\
\hline herbarium & Veronica insularis & 0.63 & $\begin{array}{l}\text { AK217304, } \\
\text { AK183138 }\end{array}$ & $\begin{array}{l}\text { Veronica } \\
\text { orchidea }\end{array}$ & 0.19 & P03516880 \\
\hline herbarium & $\begin{array}{l}\text { Xylosma } \\
\text { parvifolium }\end{array}$ & 0.14 & $\begin{array}{l}\text { MEL582311, } \\
\text { MEL582308, } \\
\text { MEL582310, } \\
\text { MEL100641 }\end{array}$ & $\begin{array}{l}\text { Xylosma } \\
\text { vincentii }\end{array}$ & 0.24 & $\begin{array}{l}\text { P00648881, } \\
\text { P002468816, } \\
\text { P0015173, } \\
\text { P04647112, } \\
\text { P00648882 }\end{array}$ \\
\hline
\end{tabular}

Table B10 Inflorescence length dataset measurements and measurement references

\begin{tabular}{|c|c|c|c|c|c|c|}
\hline $\begin{array}{l}\text { measurement } \\
\text { type }\end{array}$ & island species & $\begin{array}{l}\text { Inflorescence } \\
\text { Length Average } \\
\text { Island cm }\end{array}$ & Reference(s) & $\begin{array}{l}\text { Mainland } \\
\text { relative }\end{array}$ & $\begin{array}{l}\text { Inflorescence } \\
\text { Length Average } \\
\text { mainland } \mathrm{cm}\end{array}$ & Reference(s) \\
\hline herbarium & $\begin{array}{l}\text { Abrotanella } \\
\text { rosulata }\end{array}$ & 0.4 & TP SP102466 & $\begin{array}{l}\text { Abrotanella } \\
\text { spathulata }\end{array}$ & 0.75 & TP SP57761 \\
\hline herbarium & $\begin{array}{l}\text { Alectryon excelsus } \\
\text { grandis }\end{array}$ & 12 & $\begin{array}{l}\text { de Lange } \\
2012\end{array}$ & $\begin{array}{l}\text { Alectryon } \\
\text { excelsus } \\
\text { excelsus }\end{array}$ & 14.5 & AK337298 \\
\hline herbarium & Alyxia squamulosa & 1.75 & $\begin{array}{l}\text { Mel223111, } \\
\text { MEL223108 }\end{array}$ & $\begin{array}{l}\text { Alyxia } \\
\text { reinwardtii }\end{array}$ & 1.75 & H570/97 50 \\
\hline herbarium & $\begin{array}{l}\text { Brachyglottis } \\
\text { arborescens }\end{array}$ & 9.55 & $\begin{array}{l}\text { TP SP78892, } \\
\text { SP14393 }\end{array}$ & $\begin{array}{l}\text { Brachyglottis } \\
\text { repanda }\end{array}$ & 17.27 & TP SP58743 \\
\hline herbarium & $\begin{array}{l}\text { Brachyglottis } \\
\text { huntii }\end{array}$ & 8.34 & TP SP77964 & $\begin{array}{l}\text { Brachyglottis } \\
\text { stewartiae }\end{array}$ & 15.19 & TP SP40512 \\
\hline herbarium & $\begin{array}{l}\text { Corokia } \\
\text { macrocarpa }\end{array}$ & 5.5 & AK6736 & $\begin{array}{l}\text { Corokia } \\
\text { cotoneaster }\end{array}$ & 0.6 & P01900002 \\
\hline flora & $\begin{array}{l}\text { Dendrobium } \\
\text { moorei }\end{array}$ & 7.5 & $\begin{array}{l}\text { aussie flora } \\
\text { book, volume } \\
49\end{array}$ & $\begin{array}{l}\text { Dendrobium } \\
\text { kingianum }\end{array}$ & 11 & plantnet \\
\hline flora & Lepidium oblitum & 5.3 & NZCPN & $\begin{array}{l}\text { Lepidium } \\
\text { obtusatum }\end{array}$ & 3.3 & NZCPN \\
\hline herbarium & $\begin{array}{l}\text { Leptinella } \\
\text { featherstonii }\end{array}$ & 0.6 & MEL42209 & $\begin{array}{l}\text { Leptinella } \\
\text { serrulata }\end{array}$ & 0.5 & Lloyd 1972 \\
\hline
\end{tabular}


Appendices - Appendix B

\begin{tabular}{|c|c|c|c|c|c|c|}
\hline flora & $\begin{array}{l}\text { Melaleuca } \\
\text { howeana }\end{array}$ & 1.5 & $\begin{array}{l}\text { aussie flora } \\
\text { book, volume } \\
49\end{array}$ & $\begin{array}{l}\text { Melaleuca } \\
\text { ericifolia }\end{array}$ & 1.35 & vicflora \\
\hline herbarium & $\begin{array}{l}\text { Melicope } \\
\text { polybotrya }\end{array}$ & 6.5 & $\begin{array}{l}\text { L2124202, } \\
\text { L2124201, } \\
\text { L2124203, } \\
\text { P05184454, } \\
\text { K000717407 }\end{array}$ & $\begin{array}{l}\text { Sacromelicope } \\
\text { simpliciafolia }\end{array}$ & 7 & $\begin{array}{l}\text { P00222344, } \\
\text { P05214419 }\end{array}$ \\
\hline herbarium & $\begin{array}{l}\text { Melicytus novae- } \\
\text { zelandia subsp. } \\
\text { centurionis }\end{array}$ & 0.45 & AK5325 & $\begin{array}{l}\text { Melicytus } \\
\text { novae- } \\
\text { zelandia } \\
\text { subsp. novae- } \\
\text { zelandiae }\end{array}$ & 12 & AK369727 \\
\hline herbarium & $\begin{array}{l}\text { Metrosideros } \\
\text { kermadecensis }\end{array}$ & 2.46 & $\begin{array}{l}\text { TP SP095393, } \\
\text { SP088606 }\end{array}$ & $\begin{array}{l}\text { Metrosideros } \\
\text { excelsa }\end{array}$ & 7.09 & TP SP023044 \\
\hline herbarium & $\begin{array}{l}\text { Myrsine } \\
\text { chathamica }\end{array}$ & 6 & $\begin{array}{l}\text { AK355715, } \\
\text { AK358264 }\end{array}$ & $\begin{array}{l}\text { Myrsine } \\
\text { aquilonia }\end{array}$ & 1.5 & $\begin{array}{l}\text { MO2246496, } \\
\text { CHR551684, } \\
\text { AK226841 }\end{array}$ \\
\hline herbarium & $\begin{array}{l}\text { Negria } \\
\text { rhabdothamusides }\end{array}$ & 5.2 & $\begin{array}{l}\text { K000831478, } \\
\text { NSW402620, } \\
\text { E00642060, } \\
\text { P03851834 }\end{array}$ & $\begin{array}{l}\text { Lenbrassia } \\
\text { australiana }\end{array}$ & 9.5 & $\begin{array}{l}\text { L2819235, } \\
\text { 00453906, } \\
\text { L3793925, } \\
\text { L2819233 }\end{array}$ \\
\hline herbarium & Olearia mooneyi & 4.2 & K000838921 & $\begin{array}{l}\text { Olearia } \\
\text { argophylla }\end{array}$ & 10 & P00711258 \\
\hline herbarium & $\begin{array}{l}\text { Pennantia } \\
\text { endlicheri }\end{array}$ & 10 & L0014946 & $\begin{array}{l}\text { Pennantia } \\
\text { corymbosa }\end{array}$ & 5 & $\begin{array}{l}\text { SP086322, } \\
\text { SP08611, } \\
\text { SP083238 }\end{array}$ \\
\hline herbarium & $\begin{array}{l}\text { Pittosporum } \\
\text { bracteolatum }\end{array}$ & 4 & $\begin{array}{l}\text { W0046205, } \\
\text { W0046206 }\end{array}$ & $\begin{array}{l}\text { Pittosporum } \\
\text { umbellatum }\end{array}$ & 3.7 & TCD0010024 \\
\hline herbarium & $\begin{array}{l}\text { Plantago } \\
\text { aucklandica }\end{array}$ & 10 & K000438784 & $\begin{array}{l}\text { Plantago } \\
\text { lanigera }\end{array}$ & 0.6 & $\begin{array}{l}\text { TP } \\
\text { SP104833/A, } \\
\text { SP089135 }\end{array}$ \\
\hline flora & Plectorrhiza erecta & 3 & $\begin{array}{l}\text { aussie flora } \\
\text { book, volume } \\
49\end{array}$ & $\begin{array}{l}\text { Plectorrhiza } \\
\text { tridentata }\end{array}$ & 6.5 & plantnet \\
\hline herbarium & $\begin{array}{l}\text { Pseudopanax } \\
\text { chathamicus }\end{array}$ & 3.26 & $\begin{array}{l}\text { TP SP25031, } \\
\text { SP3307, } \\
\text { SP3351, } \\
\text { SP25068 }\end{array}$ & $\begin{array}{l}\text { Pseudopanax } \\
\text { crassifolius }\end{array}$ & 2.35 & $\begin{array}{l}\text { TP SP022836, } \\
\text { SP099142, } \\
\text { SP078845 }\end{array}$ \\
\hline herbarium & $\begin{array}{l}\text { Pseudopanax } \\
\text { kermadecensis }\end{array}$ & 3.18 & TP SP05341 & $\begin{array}{l}\text { Pseudopanax } \\
\text { arboreus }\end{array}$ & 3.36 & TP SP54311 \\
\hline herbarium & Senecio australis & 4.5 & G00468791 & $\begin{array}{l}\text { Senecio } \\
\text { minimus }\end{array}$ & 12.2 & K000852323 \\
\hline herbarium & Veronica insularis & 3 & K001070461 & $\begin{array}{l}\text { Veronica } \\
\text { orchidea }\end{array}$ & 15 & $\begin{array}{l}\text { P03516880, } \\
3308\end{array}$ \\
\hline
\end{tabular}

Table B11 Petal area dataset measurements and measurement references

\begin{tabular}{|c|c|c|c|c|c|c|}
\hline $\begin{array}{l}\text { measurement } \\
\text { type }\end{array}$ & island species & $\begin{array}{l}\text { island } \\
\text { petal area }\end{array}$ & Reference(s) & $\begin{array}{l}\text { Mainland } \\
\text { relative }\end{array}$ & $\begin{array}{l}\text { mainland } \\
\text { petal area }\end{array}$ & Reference(s) \\
\hline herbarium & $\begin{array}{l}\text { Abrotanella } \\
\text { rosulata }\end{array}$ & 0.02 & SP102466 & $\begin{array}{l}\text { Abrotanella } \\
\text { spathulata }\end{array}$ & 0.05 & SP57761 \\
\hline herbarium & $\begin{array}{l}\text { Alectryon excelsus } \\
\text { grandis }\end{array}$ & 0.06 & deLange et al. 1999 & $\begin{array}{l}\text { Alectryon } \\
\text { excelsus } \\
\text { excelsus }\end{array}$ & 0.01 & AK163401 \\
\hline herbarium & Alyxia squamulosa & 0.08 & $\begin{array}{l}\text { Mel223111, } \\
\text { MEL223108 }\end{array}$ & $\begin{array}{l}\text { Alyxia } \\
\text { reinwardtii }\end{array}$ & 0.08 & H570/97 50 \\
\hline herbarium & $\begin{array}{l}\text { Brachyglottis } \\
\text { arborescens }\end{array}$ & 0.01 & AK22882 & $\begin{array}{l}\text { Brachyglottis } \\
\text { repanda }\end{array}$ & 0.02 & AK362469 \\
\hline herbarium & $\begin{array}{l}\text { Brachyglottis } \\
\text { huntii }\end{array}$ & 0.31 & SP77964 & $\begin{array}{l}\text { Brachyglottis } \\
\text { stewartiae }\end{array}$ & 0.38 & SP40512 \\
\hline
\end{tabular}


Appendices - Appendix B

\begin{tabular}{|c|c|c|c|c|c|c|}
\hline herbarium & Carmichaelia exsul & 0.14 & MEL2120317 & $\begin{array}{l}\text { Carmichaelia } \\
\text { williamsii }\end{array}$ & 2.45 & $\begin{array}{l}\text { K000950929, } \\
\text { confirmed with } \\
\text { Nzflora }\end{array}$ \\
\hline herbarium & $\begin{array}{l}\text { Corokia } \\
\text { macrocarpa }\end{array}$ & 0.05 & AK6736 & $\begin{array}{l}\text { Corokia } \\
\text { cotoneaster }\end{array}$ & 0.05 & BR0000005948246 \\
\hline herbarium & $\begin{array}{l}\text { Dendrobium } \\
\text { moorei }\end{array}$ & 0.24 & $\begin{array}{l}\text { K001085451, } \\
\text { K001085449 }\end{array}$ & $\begin{array}{l}\text { Dendrobium } \\
\text { kingianum }\end{array}$ & 0.3 & NSW87427 \\
\hline flora & $\begin{array}{l}\text { Gentianella } \\
\text { antipoda }\end{array}$ & 0.06 & nzflora & $\begin{array}{l}\text { Gentianella } \\
\text { cerina }\end{array}$ & 0.66 & nzflora \\
\hline herbarium & $\begin{array}{l}\text { Gentianella } \\
\text { chathamica subsp. } \\
\text { Chathamica }\end{array}$ & 0.41 & $\begin{array}{l}\text { SP003354, } \\
\text { SP091523 (A) }\end{array}$ & $\begin{array}{l}\text { Gentianella } \\
\text { saxosa }\end{array}$ & 0.57 & SP47560, SP47517 \\
\hline herbarium & Lepidium oblitum & 0.01 & CHR 552303 B & $\begin{array}{l}\text { Lepidium } \\
\text { obtusatum }\end{array}$ & 0.01 & K000642772 \\
\hline herbarium & $\begin{array}{l}\text { Leptecophylla } \\
\text { robusta }\end{array}$ & 0.01 & $\begin{array}{l}\text { SP055221, } \\
\text { SP018176 }\end{array}$ & $\begin{array}{l}\text { Leptecophylla } \\
\text { juniperina }\end{array}$ & 0.01 & SP55449 \\
\hline herbarium & $\begin{array}{l}\text { Leptinella } \\
\text { featherstonii }\end{array}$ & 0.02 & MEL42209 & $\begin{array}{l}\text { Leptinella } \\
\text { serrulata }\end{array}$ & 0.04 & $\begin{array}{l}\text { SP091212, } \\
\text { confirmed by NZCPN }\end{array}$ \\
\hline herbarium & $\begin{array}{l}\text { Melaleuca } \\
\text { howeana }\end{array}$ & 0.02 & NSW365338 & $\begin{array}{l}\text { Melaleuca } \\
\text { ericifolia }\end{array}$ & 0.01 & B-W 14365-020 \\
\hline herbarium & $\begin{array}{l}\text { Melicope } \\
\text { polybotrya }\end{array}$ & 0.04 & $\begin{array}{l}\text { L2124202, } \\
\text { L2124201, } \\
\text { L2124203, } \\
\text { P05184454, } \\
\text { K000717407 }\end{array}$ & $\begin{array}{l}\text { Sacromelicope } \\
\text { simpliciafolia }\end{array}$ & 0.06 & $\begin{array}{l}\text { P00222344, } \\
\text { P05214419 }\end{array}$ \\
\hline herbarium & $\begin{array}{l}\text { Melicytus novae- } \\
\text { zelandia subsp. } \\
\text { centurionis }\end{array}$ & 0.01 & $\begin{array}{l}\text { SP029562 } \\
\text { SP029543 } \\
\text { SP029550 } \\
\text { SP067867 } \\
\text { SP085716 }\end{array}$ & $\begin{array}{l}\text { Melicytus } \\
\text { novae-zelandia } \\
\text { subsp. novae- } \\
\text { zelandiae }\end{array}$ & 0.03 & SP092870 \\
\hline herbarium & $\begin{array}{l}\text { Metrosideros } \\
\text { kermadecensis }\end{array}$ & 0.12 & $\begin{array}{l}\text { SP095393, } \\
\text { SP088606 }\end{array}$ & $\begin{array}{l}\text { Metrosideros } \\
\text { excelsa }\end{array}$ & 0.06 & SP023044 \\
\hline herbarium & $\begin{array}{l}\text { Myosotidia } \\
\text { hortensium }\end{array}$ & 0.48 & K001067060 & $\begin{array}{l}\text { Cynoglossum } \\
\text { paniculatum }\end{array}$ & 0.048 & K000573727 \\
\hline flora & $\begin{array}{l}\text { Myrsine } \\
\text { chathamica }\end{array}$ & 0.05 & nzcpn, nzflora & $\begin{array}{l}\text { Myrsine } \\
\text { aquilonia }\end{array}$ & 0.027 & nzcpn \\
\hline herbarium & $\begin{array}{l}\text { Negria } \\
\text { rhabdothamusides }\end{array}$ & 0.12 & $\begin{array}{l}\text { K000831478, } \\
\text { NSW402620, } \\
\text { E00642060, } \\
\text { P03851834 }\end{array}$ & $\begin{array}{l}\text { Lenbrassia } \\
\text { australiana }\end{array}$ & 0.09 & $\begin{array}{l}\text { L2819235, } \\
\text { 00453906, } \\
\text { L3793925, L2819233 }\end{array}$ \\
\hline herbarium & Olearia mooneyi & 0.03 & K000838921 & $\begin{array}{l}\text { Olearia } \\
\text { argophylla }\end{array}$ & 0.42 & P00711258 \\
\hline herbarium & $\begin{array}{l}\text { Pennantia } \\
\text { endlicheri }\end{array}$ & 0.05 & L0014946 & $\begin{array}{l}\text { Pennantia } \\
\text { corymbosa }\end{array}$ & 0.03 & $\begin{array}{l}\text { SP086322, SP08611, } \\
\text { SP083238 }\end{array}$ \\
\hline herbarium & $\begin{array}{l}\text { Pittosporum } \\
\text { bracteolatum }\end{array}$ & 0.45 & SP084276 & $\begin{array}{l}\text { Pittosporum } \\
\text { umbellatum }\end{array}$ & 0.42 & TCD0009989 \\
\hline flora & $\begin{array}{l}\text { Plantago } \\
\text { aucklandica }\end{array}$ & 0.01 & nzflora & $\begin{array}{l}\text { Plantago } \\
\text { lanigera }\end{array}$ & 0.01 & nzflora \\
\hline flora & Plectorrhiza erecta & 0.04 & $\begin{array}{l}\text { Australian flora } \\
\text { book, vol } 49\end{array}$ & $\begin{array}{l}\text { Plectorrhiza } \\
\text { tridentata }\end{array}$ & 0.06 & $\begin{array}{l}\text { Australian Tropical } \\
\text { Rainforest Orchids }\end{array}$ \\
\hline herbarium & $\begin{array}{l}\text { Pseudopanax } \\
\text { chathamicus }\end{array}$ & 0.06 & SP3307, SP25031 & $\begin{array}{l}\text { Pseudopanax } \\
\text { crassifolius }\end{array}$ & 0.02 & $\begin{array}{l}\text { AK6183, SP022836, } \\
\text { SP099142, } \\
\text { SP078845, }\end{array}$ \\
\hline herbarium & $\begin{array}{l}\text { Pseudopanax } \\
\text { kermadecensis }\end{array}$ & 0.04 & SP05341 & $\begin{array}{l}\text { Pseudopanax } \\
\text { arboreus }\end{array}$ & 0.05 & SP54311 \\
\hline herbarium & Raoulia goyenii & 0.02 & AK247246 & $\begin{array}{l}\text { Raoulia } \\
\text { buchananii }\end{array}$ & 0.001 & AK121993 \\
\hline herbarium & Senecio australis & 0.02 & SP82400 & $\begin{array}{l}\text { Senecio } \\
\text { minimus }\end{array}$ & 0.03 & AK347668 \\
\hline herbarium & $\begin{array}{l}\text { Senecio } \\
\text { kermadecensis }\end{array}$ & 0.05 & SP90180, SP31463 & Senecio hauwai & 0.03 & CHR $201160 \mathrm{~A}$ \\
\hline
\end{tabular}


Appendices - Appendix B

\begin{tabular}{|c|c|c|c|c|c|c|}
\hline herbarium & $\begin{array}{l}\text { Sonchus } \\
\text { grandifolius }\end{array}$ & 0.42 & SP27962, SP27948 & $\begin{array}{l}\text { Sonchus novae- } \\
\text { zelandiae }\end{array}$ & 0.25 & AK304834 \\
\hline herbarium & Sonchus kirkii & 0.06 & NSW135787 & $\begin{array}{l}\text { Sonchus } \\
\text { oleraceus }\end{array}$ & 0.05 & AK304834 \\
\hline herbarium & Veronica insularis & 0.15 & $\begin{array}{l}\text { AK217304, } \\
\text { AK183138 }\end{array}$ & $\begin{array}{l}\text { Veronica } \\
\text { orchidea }\end{array}$ & 0.13 & P03516880 \\
\hline herbarium & $\begin{array}{l}\text { Xylosma } \\
\text { parvifolium }\end{array}$ & 0.03 & $\begin{array}{l}\text { MEL582311, } \\
\text { MEL582308, } \\
\text { MEL582310, } \\
\text { MEL100641 }\end{array}$ & $\begin{array}{l}\text { Xylosma } \\
\text { vincentii }\end{array}$ & 0.06 & $\begin{array}{l}\text { P00648881, } \\
\text { P002468816, } \\
\text { P0015173, } \\
\text { P04647112, } \\
\text { P00648882 }\end{array}$ \\
\hline
\end{tabular}

Table B12 Sepal area dataset measurements and measurement references

\begin{tabular}{|c|c|c|c|c|c|c|}
\hline $\begin{array}{l}\text { measurement } \\
\text { type }\end{array}$ & island species & $\begin{array}{l}\text { island } \\
\text { sepal area }\end{array}$ & Reference(s) & $\begin{array}{l}\text { Mainland } \\
\text { relative }\end{array}$ & $\begin{array}{l}\text { island } \\
\text { sepal area }\end{array}$ & Reference(s) \\
\hline herbarium & $\begin{array}{l}\text { Abrotanella } \\
\text { rosulata }\end{array}$ & 0.01 & SP102466 & $\begin{array}{l}\text { Abrotanella } \\
\text { spathulata }\end{array}$ & 0.03 & SP57761 \\
\hline herbarium & $\begin{array}{l}\text { Alectryon excelsus } \\
\text { grandis }\end{array}$ & 0.05 & $\begin{array}{l}\text { AK5125, confirmed by } \\
\text { NZFLORA }\end{array}$ & $\begin{array}{l}\text { Alectryon excelsus } \\
\text { excelsus }\end{array}$ & 0.002 & AK163401 \\
\hline herbarium & Alyxia squamulosa & 0.02 & $\begin{array}{l}\text { Mel223111, } \\
\text { MEL223108 }\end{array}$ & Alyxia reinwardtii & 0.005 & H570/97 50 \\
\hline herbarium & $\begin{array}{l}\text { Brachyglottis } \\
\text { arborescens }\end{array}$ & 0.07 & $\begin{array}{l}\text { SP78892 } \\
\text { SP14292 }\end{array}$ & $\begin{array}{l}\text { Brachyglottis } \\
\text { repanda }\end{array}$ & 0.04 & SP58743 \\
\hline herbarium & $\begin{array}{l}\text { Brachyglottis } \\
\text { huntii }\end{array}$ & 0.16 & SP77964 & $\begin{array}{l}\text { Brachyglottis } \\
\text { stewartiae }\end{array}$ & 0.12 & SP40512 \\
\hline herbarium & Carmichaelia exsul & 0.01 & MEL2120317 & $\begin{array}{l}\text { Carmichaelia } \\
\text { williamsii }\end{array}$ & 0.43 & $\begin{array}{l}\text { K000950929, } \\
\text { confirmed with Nzflora }\end{array}$ \\
\hline herbarium & $\begin{array}{l}\text { Corokia } \\
\text { macrocarpa }\end{array}$ & 0.03 & AK6736 & $\begin{array}{l}\text { Corokia } \\
\text { cotoneaster }\end{array}$ & 0.15 & BR0000005948246 \\
\hline flora & $\begin{array}{l}\text { Dendrobium } \\
\text { moorei }\end{array}$ & 0.02 & $\begin{array}{l}\text { Australian flora book, } \\
\text { vol } 49\end{array}$ & $\begin{array}{l}\text { Dendrobium } \\
\text { kingianum }\end{array}$ & 1.18 & PlantNET \\
\hline flora & $\begin{array}{l}\text { Gentianella } \\
\text { antipoda }\end{array}$ & 0.058 & nzflora & Gentianella cerina & 0.25 & nzflora \\
\hline herbarium & $\begin{array}{l}\text { Gentianella } \\
\text { chathamica subsp. } \\
\text { Chathamica }\end{array}$ & 0.05 & $\begin{array}{l}\text { SP003354, SP091523 } \\
\text { (A) }\end{array}$ & $\begin{array}{l}\text { Gentianella } \\
\text { saxosa }\end{array}$ & 0.15 & SP47560, SP47517 \\
\hline herbarium & Lepidium oblitum & 0.01 & CHR 552303 B & $\begin{array}{l}\text { Lepidium } \\
\text { obtusatum }\end{array}$ & 0.01 & K000642772 \\
\hline herbarium & $\begin{array}{l}\text { Leptecophylla } \\
\text { robusta }\end{array}$ & 0.01 & SP055221, SP018176 & $\begin{array}{l}\text { Leptecophylla } \\
\text { juniperina }\end{array}$ & 0.02 & SP55449 \\
\hline herbarium & $\begin{array}{l}\text { Leptinella } \\
\text { featherstonii }\end{array}$ & 0.04 & MEL42209 & $\begin{array}{l}\text { Leptinella } \\
\text { serrulata }\end{array}$ & 0.01 & $\begin{array}{l}\text { SP091212, confirmed } \\
\text { by NZCPN }\end{array}$ \\
\hline herbarium & $\begin{array}{l}\text { Melaleuca } \\
\text { howeana }\end{array}$ & 0.01 & NSW365338 & $\begin{array}{l}\text { Melaleuca } \\
\text { ericifolia }\end{array}$ & 0.01 & B-W 14365-020 \\
\hline herbarium & $\begin{array}{l}\text { Melicope } \\
\text { polybotrya }\end{array}$ & 0.01 & $\begin{array}{l}\text { L2124202, L2124201, } \\
\text { L2124203, } \\
\text { P05184454, } \\
\text { K000717407 }\end{array}$ & $\begin{array}{l}\text { Sacromelicope } \\
\text { simpliciafolia }\end{array}$ & 0.02 & P00222344, P05214419 \\
\hline herbarium & $\begin{array}{l}\text { Melicytus novae- } \\
\text { zelandia subsp. } \\
\text { centurionis }\end{array}$ & 0.05 & $\begin{array}{l}\text { SP029562 } \\
\text { SP029543 } \\
\text { SP029550 } \\
\text { SP067867 } \\
\text { SP085716 }\end{array}$ & $\begin{array}{l}\text { Melicytus novae- } \\
\text { zelandia subsp. } \\
\text { novae-zelandiae }\end{array}$ & 0.004 & SP092870 \\
\hline herbarium & $\begin{array}{l}\text { Metrosideros } \\
\text { kermadecensis }\end{array}$ & 0.15 & SP095393, SP088606 & $\begin{array}{l}\text { Metrosideros } \\
\text { excelsa }\end{array}$ & 0.06 & SP023044 \\
\hline herbarium & $\begin{array}{l}\text { Myosotidia } \\
\text { hortensium }\end{array}$ & 0.08 & K001067060 & $\begin{array}{l}\text { Cynoglossum } \\
\text { paniculatum }\end{array}$ & 0.01 & K000573727 \\
\hline herbarium & $\begin{array}{l}\text { Myrsine } \\
\text { chathamica }\end{array}$ & 0.01 & AK358264 & Myrsine aquilonia & 0.01 & AK226841 \\
\hline flora & $\begin{array}{l}\text { Myrsine } \\
\text { chathamica }\end{array}$ & 0.08 & nzcpn, nzflora & Myrsine aquilonia & 0.01 & nzcpn \\
\hline
\end{tabular}




\begin{tabular}{|c|c|c|c|c|c|c|}
\hline herbarium & $\begin{array}{l}\text { Negria } \\
\text { rhabdothamusides }\end{array}$ & 0.12 & $\begin{array}{l}\text { K000831478, } \\
\text { NSW402620, } \\
\text { E00642060, } \\
\text { P03851834 }\end{array}$ & $\begin{array}{l}\text { Lenbrassia } \\
\text { australiana }\end{array}$ & 0.08 & $\begin{array}{l}\text { L2819235, 00453906, } \\
\text { L3793925, L2819233 }\end{array}$ \\
\hline herbarium & Olearia mooneyi & 0.01 & K000838921 & Olearia argophylla & 0.01 & P00711258 \\
\hline herbarium & $\begin{array}{l}\text { Pennantia } \\
\text { endlicheri }\end{array}$ & 0.01 & L0014946 & $\begin{array}{l}\text { Pennantia } \\
\text { corymbosa }\end{array}$ & 0.01 & $\begin{array}{l}\text { SP086322, SP08611, } \\
\text { SP083238 }\end{array}$ \\
\hline herbarium & $\begin{array}{l}\text { Pittosporum } \\
\text { bracteolatum }\end{array}$ & 0.12 & SP084276 & $\begin{array}{l}\text { Pittosporum } \\
\text { umbellatum }\end{array}$ & 0.15 & TCD0009989 \\
\hline flora & $\begin{array}{l}\text { Plantago } \\
\text { aucklandica }\end{array}$ & 0.02 & nzflora & Plantago lanigera & 0.05 & nzflora \\
\hline flora & Plectorrhiza erecta & 0.03 & $\begin{array}{l}\text { Australian flora book, } \\
\text { vol } 49\end{array}$ & $\begin{array}{l}\text { Plectorrhiza } \\
\text { tridentata }\end{array}$ & 0.09 & $\begin{array}{l}\text { Australian Tropical } \\
\text { Rainforest Orchids }\end{array}$ \\
\hline herbarium & $\begin{array}{l}\text { Pseudopanax } \\
\text { chathamicus }\end{array}$ & 0.03 & AK6209 & $\begin{array}{l}\text { Pseudopanax } \\
\text { crassifolius }\end{array}$ & 0.01 & AK6183 \\
\hline herbarium & $\begin{array}{l}\text { Pseudopanax } \\
\text { kermadecensis }\end{array}$ & 0.01 & K000810341 & $\begin{array}{l}\text { Pseudopanax } \\
\text { arboreus }\end{array}$ & 0.01 & GOET012768 \\
\hline herbarium & Senecio australis & 0.03 & SP82400 & Senecio minimus & 0.04 & G00301796 \\
\hline herbarium & $\begin{array}{l}\text { Senecio } \\
\text { kermadecensis }\end{array}$ & 0.003 & SP90180, SP31463 & Senecio hauwai & 0.02 & CHR 201160 A \\
\hline herbarium & $\begin{array}{l}\text { Sonchus } \\
\text { grandifolius }\end{array}$ & 0.74 & SP27962, SP27948 & $\begin{array}{l}\text { Sonchus novae- } \\
\text { zelandiae }\end{array}$ & 0.18 & K000323043 \\
\hline herbarium & Sonchus kirkii & 0.17 & NSW135787 & Sonchus oleraceus & 0.11 & AK304834 \\
\hline herbarium & Veronica insularis & 0.03 & K001070461 & Veronica orchidea & 0.05 & B-W 00163-01-0 \\
\hline herbarium & $\begin{array}{l}\text { Xylosma } \\
\text { parvifolium }\end{array}$ & 0.01 & $\begin{array}{l}\text { MEL582311, } \\
\text { MEL582308, } \\
\text { MEL582310, } \\
\text { MEL100641 }\end{array}$ & Xylosma vincentii & 0.08 & $\begin{array}{l}\text { P00648881, } \\
\text { P002468816, } \\
\text { P0015173, P04647112, } \\
\text { P00648882 }\end{array}$ \\
\hline
\end{tabular}

Table B13 Filament length dataset measurements and measurement references

\begin{tabular}{|c|c|c|c|c|c|c|}
\hline $\begin{array}{l}\text { measurement } \\
\text { type }\end{array}$ & island species & $\begin{array}{l}\text { Filament } \\
\text { length } \\
\text { island } \mathrm{mm}\end{array}$ & Reference(s) & $\begin{array}{l}\text { Mainland } \\
\text { relative }\end{array}$ & $\begin{array}{l}\text { Filament } \\
\text { length } \\
\text { mainland } \mathrm{mm}\end{array}$ & Reference(s) \\
\hline herbarium & $\begin{array}{l}\text { Alectryon excelsus } \\
\text { grandis }\end{array}$ & 0.75 & $\begin{array}{l}\text { deLange Cameron } \\
\text { \& Murray } 1999\end{array}$ & $\begin{array}{l}\text { Alectryon } \\
\text { excelsus excelsus }\end{array}$ & 1 & AK163401 \\
\hline herbarium & Alyxia squamulosa & 8 & MEL223111 & Alyxia reinwardtii & 5 & S-G-10786 \\
\hline herbarium & $\begin{array}{l}\text { Brachyglottis } \\
\text { arborescens }\end{array}$ & 2 & AK218336 & $\begin{array}{l}\text { Brachyglottis } \\
\text { repanda }\end{array}$ & 2 & AK362469 \\
\hline herbarium & Carmichaelia exsul & 4.9 & MEL2120317 & $\begin{array}{l}\text { Carmichaelia } \\
\text { williamsii }\end{array}$ & 8.5 & K000950929 \\
\hline flora & Coprosma pilosa & 3 & aussie flora book & $\begin{array}{l}\text { Coprosma } \\
\text { fowerakeri }\end{array}$ & 5.5 & nzflora \\
\hline herbarium & $\begin{array}{l}\text { Corokia } \\
\text { macrocarpa }\end{array}$ & 4 & AK6735 & $\begin{array}{l}\text { Corokia } \\
\text { cotoneaster }\end{array}$ & 2 & BR0000005948567 \\
\hline herbarium & $\begin{array}{l}\text { Dendrobium } \\
\text { moorei }\end{array}$ & 8 & K001085450 & $\begin{array}{l}\text { Dendrobium } \\
\text { kingianum }\end{array}$ & 6 & K001089618 \\
\hline flora & $\begin{array}{l}\text { Gentianella } \\
\text { antipoda }\end{array}$ & 4.55 & nzflora & $\begin{array}{l}\text { Gentianella } \\
\text { cerina }\end{array}$ & 5.9 & nzflora \\
\hline flora & $\begin{array}{l}\text { Gentianella } \\
\text { chathamica subsp. } \\
\text { chathamica }\end{array}$ & 2.41 & nzflora & $\begin{array}{l}\text { Gentianella } \\
\text { saxosa }\end{array}$ & 7.85 & nzflora \\
\hline herbarium & Lepidium oblitum & 1 & CHR 552303 B & $\begin{array}{l}\text { Lepidium } \\
\text { obtusatum }\end{array}$ & 1 & K000642772 \\
\hline flora & $\begin{array}{l}\text { Leptecophylla } \\
\text { robusta }\end{array}$ & 0.55 & nzcpn & $\begin{array}{l}\text { Leptecophylla } \\
\text { juniperina }\end{array}$ & 0.35 & nzcpn \\
\hline herbarium & $\begin{array}{l}\text { Melaleuca } \\
\text { howeana }\end{array}$ & 2.8 & NSW365338 & $\begin{array}{l}\text { Melaleuca } \\
\text { ericifolia }\end{array}$ & 4.5 & B-W 14365-020 \\
\hline herbarium & $\begin{array}{l}\text { Melicytus novae- } \\
\text { zelandia subsp. } \\
\text { centurionis }\end{array}$ & 0.67 & $\begin{array}{l}\text { SP029562, } \\
\text { SP029543, } \\
\text { SP029550, }\end{array}$ & $\begin{array}{l}\text { Melicytus novae- } \\
\text { zelandia subsp. } \\
\text { novae-zelandiae }\end{array}$ & 2 & AK5327 \\
\hline
\end{tabular}


Appendices - Appendix B

\begin{tabular}{|c|c|c|c|c|c|c|}
\hline & & & $\begin{array}{l}\text { SP067867, } \\
\text { SP085716 }\end{array}$ & & & \\
\hline herbarium & $\begin{array}{l}\text { Metrosideros } \\
\text { kermadecensis }\end{array}$ & 16 & $\begin{array}{l}\text { SP095393, } \\
\text { SP088606 }\end{array}$ & $\begin{array}{l}\text { Metrosideros } \\
\text { excelsa }\end{array}$ & 23.89 & AK358098, SP023044 \\
\hline herbarium & $\begin{array}{l}\text { Negria } \\
\text { rhabdothamusides }\end{array}$ & 1.1 & $\begin{array}{l}\text { K000831478, } \\
\text { NSW402620, } \\
\text { E00642060, } \\
\text { P03851834 }\end{array}$ & $\begin{array}{l}\text { Lenbrassia } \\
\text { australiana }\end{array}$ & 1.6 & $\begin{array}{l}\text { L2819235, 00453906, } \\
\text { L3793925, L2819233 }\end{array}$ \\
\hline herbarium & Olearia mooneyi & 3.5 & K000838921 & $\begin{array}{l}\text { Olearia } \\
\text { argophylla }\end{array}$ & 4 & P00711258 \\
\hline flora & $\begin{array}{l}\text { Plantago } \\
\text { aucklandica }\end{array}$ & 0.34 & nzflora & $\begin{array}{l}\text { Plantago } \\
\text { lanigera }\end{array}$ & 0.43 & nzflora \\
\hline herbarium & Plectorrhiza erecta & 3 & Dockrill 1967 & $\begin{array}{l}\text { Plectorrhiza } \\
\text { tridentata }\end{array}$ & 4 & MEL1540868 \\
\hline herbarium & $\begin{array}{l}\text { Pseudopanax } \\
\text { chathamicus }\end{array}$ & 5 & AK6209 & $\begin{array}{l}\text { Pseudopanax } \\
\text { crassifolius }\end{array}$ & 2.2 & AK6183 \\
\hline herbarium & $\begin{array}{l}\text { Pseudopanax } \\
\text { kermadecensis }\end{array}$ & 1.33 & SP05341 & $\begin{array}{l}\text { Pseudopanax } \\
\text { arboreus }\end{array}$ & 4.19 & SP54311 \\
\hline herbarium & Senecio australis & 3.7 & G00468791 & Senecio minimus & 0.4 & K000852323 \\
\hline herbarium & $\begin{array}{l}\text { Sonchus } \\
\text { grandifolius }\end{array}$ & 1.8 & K000808042 & $\begin{array}{l}\text { Sonchus novae- } \\
\text { zelandiae }\end{array}$ & 0.8 & K000323043 \\
\hline herbarium & Sonchus kirkii & 10 & NSW135787 & $\begin{array}{l}\text { Sonchus } \\
\text { oleraceus }\end{array}$ & 15 & K001118926 \\
\hline herbarium & Veronica insularis & 4 & K001070461 & $\begin{array}{l}\text { Veronica } \\
\text { orchidea }\end{array}$ & 6.39 & P03516880 \\
\hline herbarium & $\begin{array}{l}\text { Xylosma } \\
\text { parvifolium }\end{array}$ & 0.25 & $\begin{array}{l}\text { MEL582311, } \\
\text { MEL582308, } \\
\text { MEL582310, } \\
\text { MEL100641 }\end{array}$ & Xylosma vincentii & 0.3 & $\begin{array}{l}\text { P00648881, } \\
\text { P002468816, } \\
\text { P0015173, } \\
\text { P04647112, } \\
\text { P00648882 }\end{array}$ \\
\hline
\end{tabular}

Table B14 Anther length dataset measurements and measurement references

\begin{tabular}{|c|c|c|c|c|c|c|}
\hline $\begin{array}{l}\text { measurement } \\
\text { type }\end{array}$ & island species & $\begin{array}{l}\text { Anther } \\
\text { length } \\
\text { island } \mathrm{cm}\end{array}$ & Reference(s) & Mainland relative & $\begin{array}{l}\text { Anther } \\
\text { length } \\
\text { mainland cm }\end{array}$ & Reference(s) \\
\hline herbarium & $\begin{array}{l}\text { Alectryon excelsus } \\
\text { grandis }\end{array}$ & 0.2 & $\begin{array}{l}\text { deLange } \\
\text { Cameron \& } \\
\text { Murray } 1999\end{array}$ & $\begin{array}{l}\text { Alectryon } \\
\text { excelsus excelsus }\end{array}$ & 0.03 & AK163401 \\
\hline herbarium & Alyxia squamulosa & 0.03 & MEL223111 & Alyxia reinwardtii & 0.05 & (S), S-G-10786 \\
\hline herbarium & $\begin{array}{l}\text { Brachyglottis } \\
\text { arborescens }\end{array}$ & 0.25 & AK22882 & $\begin{array}{l}\text { Brachyglottis } \\
\text { repanda }\end{array}$ & 0.08 & AK10522 \\
\hline flora & Coprosma pilosa & 0.02 & $\begin{array}{l}\text { aussie flora } \\
\text { book, vol } 49\end{array}$ & $\begin{array}{l}\text { Coprosma } \\
\text { fowerakeri }\end{array}$ & 0.27 & nzflora \\
\hline herbarium & $\begin{array}{l}\text { Corokia } \\
\text { macrocarpa }\end{array}$ & 0.1 & AK6735 & $\begin{array}{l}\text { Corokia } \\
\text { cotoneaster }\end{array}$ & 0.03 & BR0000005948567 \\
\hline herbarium & Dendrobium moorei & 0.07 & K001085450 & $\begin{array}{l}\text { Dendrobium } \\
\text { kingianum }\end{array}$ & 0.05 & K001089618 \\
\hline flora & Festuca coxii & 0.39 & floraseries & Festuca luciarum & 0.26 & nzflora \\
\hline flora & $\begin{array}{l}\text { Gentianella } \\
\text { antipoda }\end{array}$ & 0.08 & nzflora & $\begin{array}{l}\text { Gentianella } \\
\text { cerina }\end{array}$ & 0.13 & nzflora \\
\hline flora & $\begin{array}{l}\text { Gentianella } \\
\text { chathamica subsp. } \\
\text { Chathamica }\end{array}$ & 0.09 & nzflora & $\begin{array}{l}\text { Gentianella } \\
\text { saxosa }\end{array}$ & 0.2 & nzflora \\
\hline herbarium & Lepidium oblitum & 0.01 & CHR 552303 B & $\begin{array}{l}\text { Lepidium } \\
\text { obtusatum }\end{array}$ & 0.05 & K000642772 \\
\hline flora & $\begin{array}{l}\text { Leptecophylla } \\
\text { robusta }\end{array}$ & 0.13 & nzcpn & $\begin{array}{l}\text { Leptecophylla } \\
\text { juniperina }\end{array}$ & 0.15 & nzcpn \\
\hline herbarium & $\begin{array}{l}\text { Melaleuca } \\
\text { howeana }\end{array}$ & 0.03 & NSW365338 & $\begin{array}{l}\text { Melaleuca } \\
\text { ericifolia }\end{array}$ & 0.02 & B-W 14365-020 \\
\hline
\end{tabular}


Appendices - Appendix B

\begin{tabular}{|c|c|c|c|c|c|c|}
\hline herbarium & $\begin{array}{l}\text { Melicytus novae- } \\
\text { zelandia subsp. } \\
\text { centurionis }\end{array}$ & 0.09 & AK5325 & $\begin{array}{l}\text { Melicytus novae- } \\
\text { zelandia subsp. } \\
\text { novae-zelandiae }\end{array}$ & 0.08 & AK5327 \\
\hline herbarium & $\begin{array}{l}\text { Metrosideros } \\
\text { kermadecensis }\end{array}$ & 0.1 & $\begin{array}{l}\text { SP095393, } \\
\text { SP088606 }\end{array}$ & $\begin{array}{l}\text { Metrosideros } \\
\text { excelsa }\end{array}$ & 0.1 & SP023044 \\
\hline herbarium & $\begin{array}{l}\text { Myosotidia } \\
\text { hortensium }\end{array}$ & 0.11 & K001067060 & $\begin{array}{l}\text { Cynoglossum } \\
\text { paniculatum }\end{array}$ & 0.2 & K000573727 \\
\hline flora & $\begin{array}{l}\text { Myrsine } \\
\text { chathamica }\end{array}$ & 0.2 & nzcpn, nzflora & $\begin{array}{l}\text { Myrsine } \\
\text { aquilonia }\end{array}$ & 0.15 & nzcpn \\
\hline herbarium & $\begin{array}{l}\text { Negria } \\
\text { rhabdothamusides }\end{array}$ & 0.2 & $\begin{array}{l}\text { K000831478, } \\
\text { NSW402620, } \\
\text { E00642060, } \\
\text { P03851834 }\end{array}$ & $\begin{array}{l}\text { Lenbrassia } \\
\text { australiana }\end{array}$ & 0.1 & $\begin{array}{l}\text { L2819235, } \\
\text { 00453906, } \\
\text { L3793925, L2819233 }\end{array}$ \\
\hline herbarium & $\begin{array}{l}\text { Pittosporum } \\
\text { bracteolatum }\end{array}$ & 0.3 & SP084276 & $\begin{array}{l}\text { Pittosporum } \\
\text { umbellatum }\end{array}$ & 2 & $\begin{array}{l}\text { P02502872, } \\
\text { P02502869, AK4683 }\end{array}$ \\
\hline flora & $\begin{array}{l}\text { Plantago } \\
\text { aucklandica }\end{array}$ & 0.12 & nzflora & $\begin{array}{l}\text { Plantago } \\
\text { lanigera }\end{array}$ & 0.1 & nzflora \\
\hline herbarium & Plectorrhiza erecta & 0.04 & Dockrill 1967 & $\begin{array}{l}\text { Plectorrhiza } \\
\text { tridentata }\end{array}$ & 0.05 & MEL1540868 \\
\hline flora & Poa chathamica & 0.27 & nzflora & Poa cita & 0.2 & nzflora \\
\hline herbarium & $\begin{array}{l}\text { Pseudopanax } \\
\text { chathamicus }\end{array}$ & 0.05 & AK6209 & $\begin{array}{l}\text { Pseudopanax } \\
\text { crassifolius }\end{array}$ & 0.1 & AK6183 \\
\hline herbarium & $\begin{array}{l}\text { Pseudopanax } \\
\text { kermadecensis }\end{array}$ & 0.11 & SP05341 & $\begin{array}{l}\text { Pseudopanax } \\
\text { arboreus }\end{array}$ & 0.12 & SP54311 \\
\hline herbarium & Senecio australis & 0.02 & G00468791 & Senecio minimus & 0.02 & K000852323 \\
\hline herbarium & Veronica insularis & 0.09 & $\begin{array}{l}\text { AK217304, } \\
\text { AK183138 }\end{array}$ & $\begin{array}{l}\text { Veronica } \\
\text { orchidea }\end{array}$ & 0.19 & P03516880 \\
\hline herbarium & $\begin{array}{l}\text { Xylosma } \\
\text { parvifolium }\end{array}$ & 0.05 & $\begin{array}{l}\text { MEL582311, } \\
\text { MEL582308, } \\
\text { MEL582310, } \\
\text { MEL100641 }\end{array}$ & Xylosma vincentii & 0.02 & $\begin{array}{l}\text { P00648881, } \\
\text { P002468816, } \\
\text { P0015173, } \\
\text { P04647112, } \\
\text { P00648882 }\end{array}$ \\
\hline
\end{tabular}

Table B15 Pedicel length dataset measurements and measurement references

\begin{tabular}{|c|c|c|c|c|c|c|}
\hline $\begin{array}{l}\text { measurement } \\
\text { type }\end{array}$ & island taxonomy & $\begin{array}{l}\text { pedicel } \\
\text { length } \\
\text { island } \mathrm{cm}\end{array}$ & Reference(s) & $\begin{array}{l}\text { Mainland } \\
\text { relative }\end{array}$ & $\begin{array}{l}\text { Pedicel length } \\
\text { mainland } \mathrm{cm}\end{array}$ & Reference(s) \\
\hline herbarium & $\begin{array}{l}\text { Abrotanella } \\
\text { rosulata }\end{array}$ & 0.9 & P00852291 & $\begin{array}{l}\text { Abrotanella } \\
\text { spathulata }\end{array}$ & 1.05 & SP57761 \\
\hline herbarium & $\begin{array}{l}\text { Alectryon excelsus } \\
\text { grandis }\end{array}$ & 0.23 & $\begin{array}{l}\text { De Lange et al. } \\
2010\end{array}$ & $\begin{array}{l}\text { Alectryon } \\
\text { excelsus } \\
\text { excelsus }\end{array}$ & 0.3 & AK163401 \\
\hline herbarium & Alyxia squamulosa & 0.42 & $\begin{array}{l}\text { Mel223111, } \\
\text { MEL223108 }\end{array}$ & $\begin{array}{l}\text { Alyxia } \\
\text { reinwardtii }\end{array}$ & 0.5 & H570/97 50 \\
\hline herbarium & $\begin{array}{l}\text { Brachyglottis } \\
\text { arborescens }\end{array}$ & 1 & SP78892, SP14292 & $\begin{array}{l}\text { Brachyglottis } \\
\text { repanda }\end{array}$ & 0.27 & SP58743 \\
\hline herbarium & $\begin{array}{l}\text { Brachyglottis } \\
\text { huntii }\end{array}$ & 1.16 & SP77964 & $\begin{array}{l}\text { Brachyglottis } \\
\text { stewartiae }\end{array}$ & 0.75 & SP40512 \\
\hline herbarium & Carmichaelia exsul & 0.32 & MEL2120317 & $\begin{array}{l}\text { Carmichaelia } \\
\text { williamsii }\end{array}$ & 0.6 & K000950929 \\
\hline herbarium & $\begin{array}{l}\text { Corokia } \\
\text { macrocarpa }\end{array}$ & 0.5 & K000739753 & $\begin{array}{l}\text { Corokia } \\
\text { cotoneaster }\end{array}$ & 0.2 & BR0000005948246 \\
\hline herbarium & $\begin{array}{l}\text { Cryptocarya } \\
\text { gregsonii }\end{array}$ & 1.5 & $\begin{array}{l}\text { NSW524068, } \\
\text { NSW524032 }\end{array}$ & $\begin{array}{l}\text { Cryptocarya } \\
\text { densiflora }\end{array}$ & 0.35 & GH00041368 \\
\hline herbarium & $\begin{array}{l}\text { Dendrobium } \\
\text { moorei }\end{array}$ & 1.8 & $\begin{array}{l}\text { K001085451, } \\
\text { K001085449 }\end{array}$ & $\begin{array}{l}\text { Dendrobium } \\
\text { kingianum }\end{array}$ & 1.4 & NSW87427 \\
\hline flora & $\begin{array}{l}\text { Gentianella } \\
\text { antipoda }\end{array}$ & 0.14 & nzflora & $\begin{array}{l}\text { Gentianella } \\
\text { cerina }\end{array}$ & 0.12 & nzflora \\
\hline flora & $\begin{array}{l}\text { Gentianella } \\
\text { chathamica subsp. } \\
\text { Chathamica }\end{array}$ & 0.13 & nzflora & $\begin{array}{l}\text { Gentianella } \\
\text { saxosa }\end{array}$ & 0.15 & nzflora \\
\hline
\end{tabular}


Appendices - Appendix B

\begin{tabular}{|c|c|c|c|c|c|c|}
\hline flora & Lepidium oblitum & 0.07 & NZCPN & $\begin{array}{l}\text { Lepidium } \\
\text { obtusatum }\end{array}$ & 0.4 & NZCPN \\
\hline flora & $\begin{array}{l}\text { Leptecophylla } \\
\text { robusta }\end{array}$ & 0.32 & NZCPN & $\begin{array}{l}\text { Leptecophylla } \\
\text { juniperina }\end{array}$ & 0.28 & NZCPN \\
\hline herbarium & $\begin{array}{l}\text { Leptinella } \\
\text { featherstonii }\end{array}$ & 0.8 & MEL42209 & $\begin{array}{l}\text { Leptinella } \\
\text { serrulata }\end{array}$ & 2 & SP091212 \\
\hline herbarium & $\begin{array}{l}\text { Melaleuca } \\
\text { howeana }\end{array}$ & 0.03 & NSW365338 & $\begin{array}{l}\text { Melaleuca } \\
\text { ericifolia }\end{array}$ & 0.05 & B-W 14365-020 \\
\hline herbarium & $\begin{array}{l}\text { Melicope } \\
\text { polybotrya }\end{array}$ & 0.5 & $\begin{array}{l}\text { L2124202, } \\
\text { L2124201, } \\
\text { L2124203, } \\
\text { P05184454, } \\
\text { K000717407 }\end{array}$ & $\begin{array}{l}\text { Sacromelicope } \\
\text { simpliciafolia }\end{array}$ & 0.1 & $\begin{array}{l}\text { P00222344, } \\
\text { P05214419 }\end{array}$ \\
\hline herbarium & $\begin{array}{l}\text { Melicytus novae- } \\
\text { zelandia subsp. } \\
\text { centurionis }\end{array}$ & 0.92 & $\begin{array}{l}\text { SP029562, } \\
\text { SP029543, } \\
\text { SP029550, } \\
\text { SP067867, } \\
\text { SP085716 }\end{array}$ & $\begin{array}{l}\text { Melicytus } \\
\text { novae-zelandia } \\
\text { subsp. novae- } \\
\text { zelandiae }\end{array}$ & 0.29 & SP092870 \\
\hline herbarium & $\begin{array}{l}\text { Metrosideros } \\
\text { kermadecensis }\end{array}$ & 0.75 & $\begin{array}{l}\text { SP095393, } \\
\text { SP088606 }\end{array}$ & $\begin{array}{l}\text { Metrosideros } \\
\text { excelsa }\end{array}$ & 0.42 & CHR296099 \\
\hline herbarium & $\begin{array}{l}\text { Myosotidia } \\
\text { hortensium }\end{array}$ & 1 & K001067060 & $\begin{array}{l}\text { Cynoglossum } \\
\text { paniculatum }\end{array}$ & 2.5 & K000573727 \\
\hline herbarium & $\begin{array}{l}\text { Myrsine } \\
\text { chathamica }\end{array}$ & 0.12 & AK358264 & $\begin{array}{l}\text { Myrsine } \\
\text { aquilonia }\end{array}$ & 0.13 & AK226841 \\
\hline herbarium & $\begin{array}{l}\text { Myrsine } \\
\text { chathamica }\end{array}$ & 0.2 & $\begin{array}{l}\text { AK355715, } \\
\text { AK358264 }\end{array}$ & $\begin{array}{l}\text { Myrsine } \\
\text { aquilonia }\end{array}$ & 0.1 & $\begin{array}{l}\text { MO2246496, } \\
\text { CHR551684, } \\
\text { AK226841 }\end{array}$ \\
\hline herbarium & $\begin{array}{l}\text { Negria } \\
\text { rhabdothamusides }\end{array}$ & 1.8 & $\begin{array}{l}\text { K000831478, } \\
\text { NSW402620, } \\
\text { E00642060, } \\
\text { P03851834 }\end{array}$ & $\begin{array}{l}\text { Lenbrassia } \\
\text { australiana }\end{array}$ & 2.3 & $\begin{array}{l}\text { L2819235, 00453906, } \\
\text { L3793925, L2819233 }\end{array}$ \\
\hline herbarium & Olearia mooneyi & 1.1 & K000838921 & $\begin{array}{l}\text { Olearia } \\
\text { argophylla }\end{array}$ & 0.9 & P00711258 \\
\hline herbarium & $\begin{array}{l}\text { Pennantia } \\
\text { endlicheri }\end{array}$ & 1 & L0014946 & $\begin{array}{l}\text { Pennantia } \\
\text { corymbosa }\end{array}$ & 0.5 & $\begin{array}{l}\text { SP086322, SP08611, } \\
\text { SP083238 }\end{array}$ \\
\hline herbarium & $\begin{array}{l}\text { Pittosporum } \\
\text { bracteolatum }\end{array}$ & 1 & K000591735 & $\begin{array}{l}\text { Pittosporum } \\
\text { umbellatum }\end{array}$ & 1.45 & K000591694 \\
\hline herbarium & $\begin{array}{l}\text { Plantago } \\
\text { aucklandica }\end{array}$ & 8 & K000438784 & $\begin{array}{l}\text { Plantago } \\
\text { lanigera }\end{array}$ & 1.5 & $\begin{array}{l}\text { SP104833/A, } \\
\text { SP089135 }\end{array}$ \\
\hline herbarium & Plectorrhiza erecta & 1.12 & Dockrill 1967 & $\begin{array}{l}\text { Plectorrhiza } \\
\text { tridentata }\end{array}$ & 0.3 & MEL1540868 \\
\hline herbarium & $\begin{array}{l}\text { Pseudopanax } \\
\text { chathamicus }\end{array}$ & 0.7 & K000810129 & $\begin{array}{l}\text { Pseudopanax } \\
\text { crassifolius }\end{array}$ & 0.5 & BR0000005785070 \\
\hline herbarium & $\begin{array}{l}\text { Pseudopanax } \\
\text { kermadecensis }\end{array}$ & 0.4 & K000810341 & $\begin{array}{l}\text { Pseudopanax } \\
\text { arboreus }\end{array}$ & 0.5 & GOET012768 \\
\hline herbarium & Senecio australis & 1.62 & SP82400 & Senecio minimus & 0.27 & AK347668 \\
\hline herbarium & $\begin{array}{l}\text { Senecio } \\
\text { kermadecensis }\end{array}$ & 0.72 & SP90180, SP31463 & Senecio hauwai & 1.35 & CHR 201160 A \\
\hline herbarium & $\begin{array}{l}\text { Sonchus } \\
\text { grandifolius }\end{array}$ & 2.06 & NSW135787 & $\begin{array}{l}\text { Sonchus novae- } \\
\text { zelandiae }\end{array}$ & 28 & AK304834 \\
\hline herbarium & Sonchus kirkii & 1.92 & NSW135787 & $\begin{array}{l}\text { Sonchus } \\
\text { oleraceus }\end{array}$ & 2.57 & AK304834 \\
\hline herbarium & Veronica insularis & 0.6 & K001070461 & $\begin{array}{l}\text { Veronica } \\
\text { orchidea }\end{array}$ & 0.15 & B-W 00163-01-0 \\
\hline herbarium & $\begin{array}{l}\text { Xylosma } \\
\text { parvifolium }\end{array}$ & 0.7 & $\begin{array}{l}\text { MEL582311, } \\
\text { MEL582308, } \\
\text { MEL582310, } \\
\text { MEL100641 }\end{array}$ & $\begin{array}{l}\text { Xylosma } \\
\text { vincentii }\end{array}$ & 0.6 & $\begin{array}{l}\text { P00648881, } \\
\text { P002468816, } \\
\text { P0015173, } \\
\text { P04647112, } \\
\text { P00648882 }\end{array}$ \\
\hline
\end{tabular}


Appendix C: Chapter 3 supplementary material

Analysis of different factors

Table C1 Analysis of Island Rule in vegetative features across Latitude

\begin{tabular}{lrrrl}
\hline Morphological feature & \multicolumn{1}{l}{ t value } & p values & \multicolumn{1}{l}{ R squared } & F statistic \\
\hline Stature & 1.784 & 0.7934 & 0.004961 & 3.184 on 1 and $61 \mathrm{df}$ \\
\hline leaf area & 0.988 & 0.327 & 0.016 & 0.9753 on 1 and $60 \mathrm{df}$ \\
\hline petiole length & 0.481 & 0.6333 & 0.00067 & 0.2318 on 1 and $34 \mathrm{df}$ \\
\hline
\end{tabular}

Table C2 Analysis of Island Rule in Stature with outlier

\begin{tabular}{lcccccc}
\hline & T value & P value & F stat & R squared & $\begin{array}{l}\text { Slope } \\
(95 \% \mathrm{Cl})\end{array}$ \\
\hline Model 1 & -3.34 & 0.01 & 11.13 on 1 and 52 df & 0.17 & - \\
\hline Model 2 & 8.39 & $3.09 \mathrm{e}^{\wedge}-11$ & - & - & 0.72 \\
Latitude & -0.41 & 0.68 & 0.18 on 1 and 52 df & 0.01 & (0.54 to 0.89) \\
\hline
\end{tabular}

Different Analysis factors

\begin{tabular}{|c|c|}
\hline Factor & Description \\
\hline island & $\begin{array}{l}\text { The island of origin for an insular endemic species. Any large discrepencies as a } \\
\text { result of island may indicate environmental differences. }\end{array}$ \\
\hline measure & Where the measurements came from. Either herbaria or a floral description \\
\hline endemic & $\begin{array}{l}\text { The total number of endemic plant species in total from the given island of } \\
\text { occurence }\end{array}$ \\
\hline order & $\begin{array}{l}\text { The total number of endemic plant species within the same taxonomic order } \\
\text { from the same island of occurence }\end{array}$ \\
\hline type & The generic type of plant (e.g. shrub, tree, herb) \\
\hline Orderz & $\begin{array}{l}\text { The taxonomic order of a plant. This factor indicates if there are tendancies of } \\
\text { the lineage to display certain characterisitics, regardless of the plant posisiotning } \\
\text { in the landscape }\end{array}$ \\
\hline
\end{tabular}

Table C3 Analysis of Island Rule in Stature against different factors

\begin{tabular}{|c|c|c|c|c|}
\hline & T value & $P$ value & F stat & R squared \\
\hline island & 3.13 & 0.14 & 1.68 on 7 and $45 \mathrm{df}$ & 0.21 \\
\hline measure & 0.154 & 0.88 & 0.023 on 1 and $51 \mathrm{df}$ & 0.0004 \\
\hline endemic & -2.66 & 0.44 & 4.269 on 1 and $51 \mathrm{df}$ & 0.08 \\
\hline order & -1.11 & 0.27 & 1.226 on 1 and $51 \mathrm{df}$ & 0.27 \\
\hline type & -1.12 & 0.6 & 0.841 on 11 and $41 \mathrm{df}$ & 0.6 \\
\hline Orderz & 1.21 & 0.71 & 0.785 on 19 and $33 \mathrm{df}$ & 0.31 \\
\hline rainfall & -5.07 & $5.35 e^{-6 *}$ & 25.72 on $1 \& 52$ DF & 0.33 (Adjusted 0.32) \\
\hline temp & 0.45 & 0.65 & 0.20 on $1 \& 52$ DF & 0.004 (Adjusted -0.02) \\
\hline wind & -3.55 & $0.0008 *$ & $12.631 \& 52 \mathrm{DF}$ & 0.19 (Adjusted 0.18) \\
\hline size & 2.46 & $0.02 *$ & 6.06 on $1 \& 52$ DF & 0.10 (Adjusted 0.09) \\
\hline
\end{tabular}


Table C4 Analysis of Island Rule in Leaf area against different factors

\begin{tabular}{lcccc}
\hline & T value & P value & \multicolumn{1}{l}{ F stat } & R squared \\
\hline island & 4.22 & 0.15 & 1.586 on 8 \& 48 DF & 0.21 \\
\hline measure & -1.33 & 0.89 & 1.77 on 1 \& 55 DF & 0,3 \\
\hline endemic & -2.31 & 0.25 & 5.319 on 1 \& 55 DF & 0.01 \\
\hline order & -0.66 & 0.51 & 0.4353 on 1 \&55 DF & 0.01 \\
\hline type & 2.7 & 0.66 & 0.7789 on 11 \& 45 DF & 0.16 \\
\hline Orderz & -5.83 & 0.81 & 0.678 on 18 \& 38 DF & 0.24 \\
\hline rainfall & -1.48 & 0.14 & 2.21 on 1 \& 55 DF & 0.04 (Adjusted 0.02) \\
\hline temp & -1.55 & 0.13 & 2.40 on 1 \& 55 DF & 0.04 (Adjusted 0.02) \\
\hline wind & -0.62 & 0.54 & 0.38 on 1 \& 55 DF & 0.006 (Adjusted -0.01) \\
\hline size & 1.94 & 0.06 & 3.75 on 1 \& 55 DF & 0.06 (Adjusted 0.05)
\end{tabular}

Table C5 Analysis of Island Rule in petiole length against different factors

\begin{tabular}{lcccc}
\hline & T value & P value & F stat & R squared \\
\hline island & -0.12 & 0.7 & 0.55 on 4 \& 31 DF & 0.07 \\
\hline measure & 0.395 & 0.69 & 0.156 on 1 \& 34 DF & 0.004 \\
\hline endemic & -0.795 & 0.43 & 0.63 on 1 \& 34 DF & 0.02 \\
\hline order & -0.56 & 0.58 & 0.32 on 1 \& 34 DF & 0.01 \\
\hline type & 1.727 & 0.65 & 0.69 on 6 \& 29 DF & 0.13 \\
\hline Orderz & 3.036 & 0.16 & 1.58 on 13 \& 22 DF & 0.48 \\
\hline rainfall & -1.22 & 0.23 & 1.49 on 1 \& 34 DF & 0.04 (Adjusted 0.01) \\
\hline temp & -0.73 & 0.47 & 0.53 on 1 \& 34 DF & 0.02 (Adjusted -0.01) \\
\hline wind & -0.73 & 0.47 & 0.53 on 1 \& 34 DF & 0.02 (Adjusted -0.01) \\
\hline size & 0.43 & 0.67 & 0.19 on 1 \& 34 DF & 0.005 (Adjusted -0.02)
\end{tabular}

\section{Supplementary graphs}
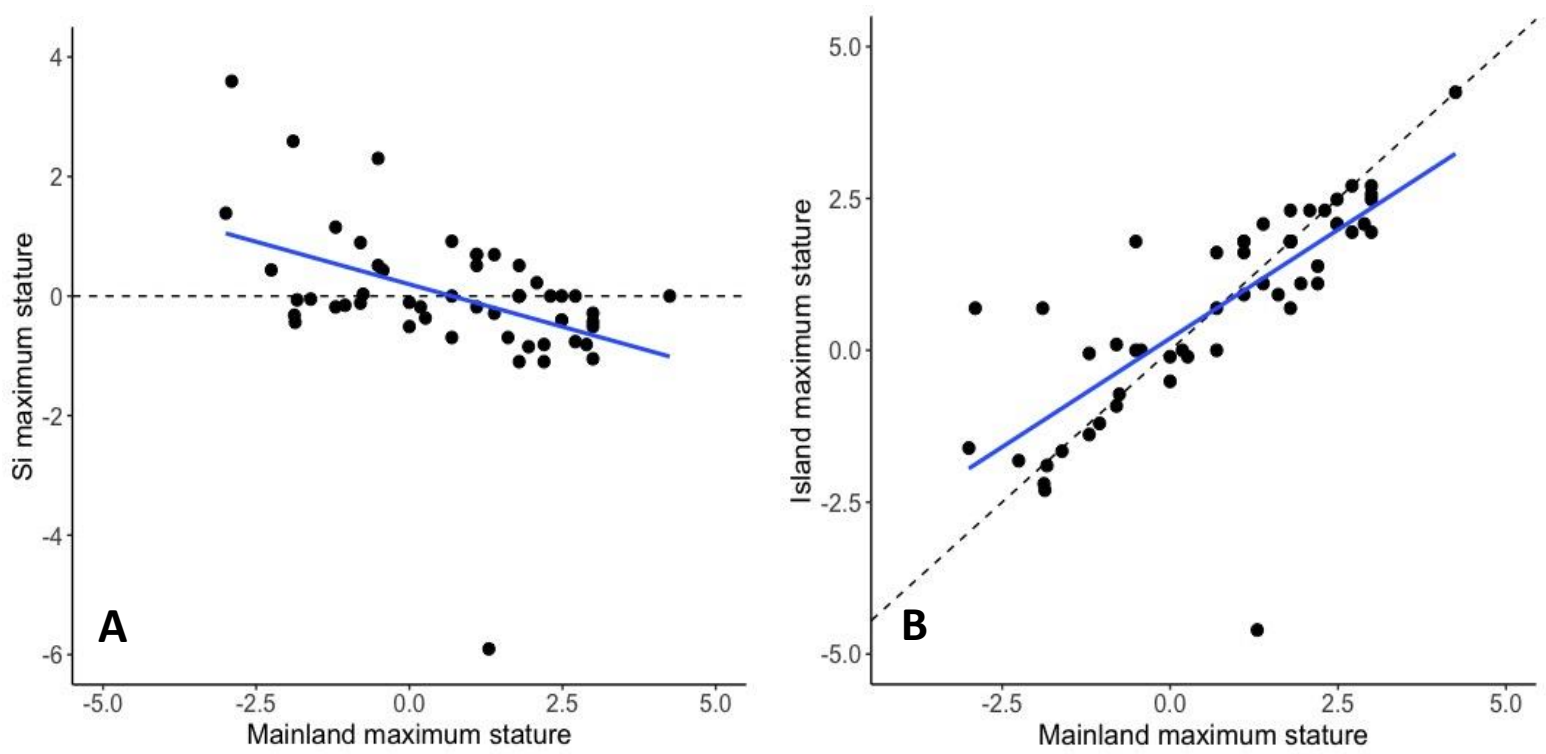

Figure C1 Maximum stature length comparison of Island versus mainland. A) Comparing Si against Mainland maximum stature. $R^{2}=0.2141$. B) Comparing Island against Mainland maximum stature. $R=0.8154$. (Both axes are natural logged) 


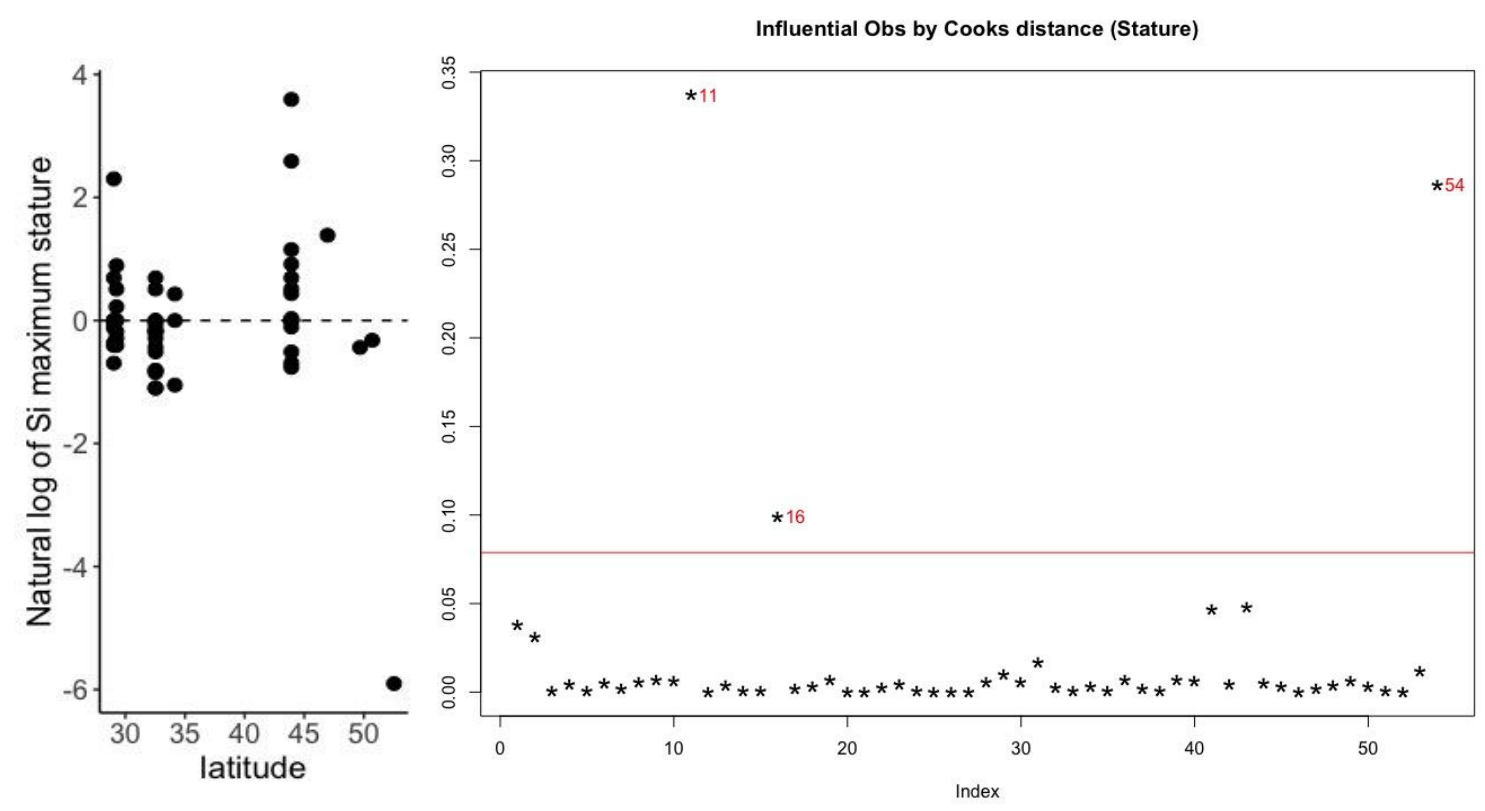

Figure C2 Non-significant graphic results of presence Figure C3 Cook's distance result demonstrating that Arbotanella is indeed a significant outlier. of the Island Rule across latitude for stature (including outlier). $\mathrm{Y}$ axis is natural logged.
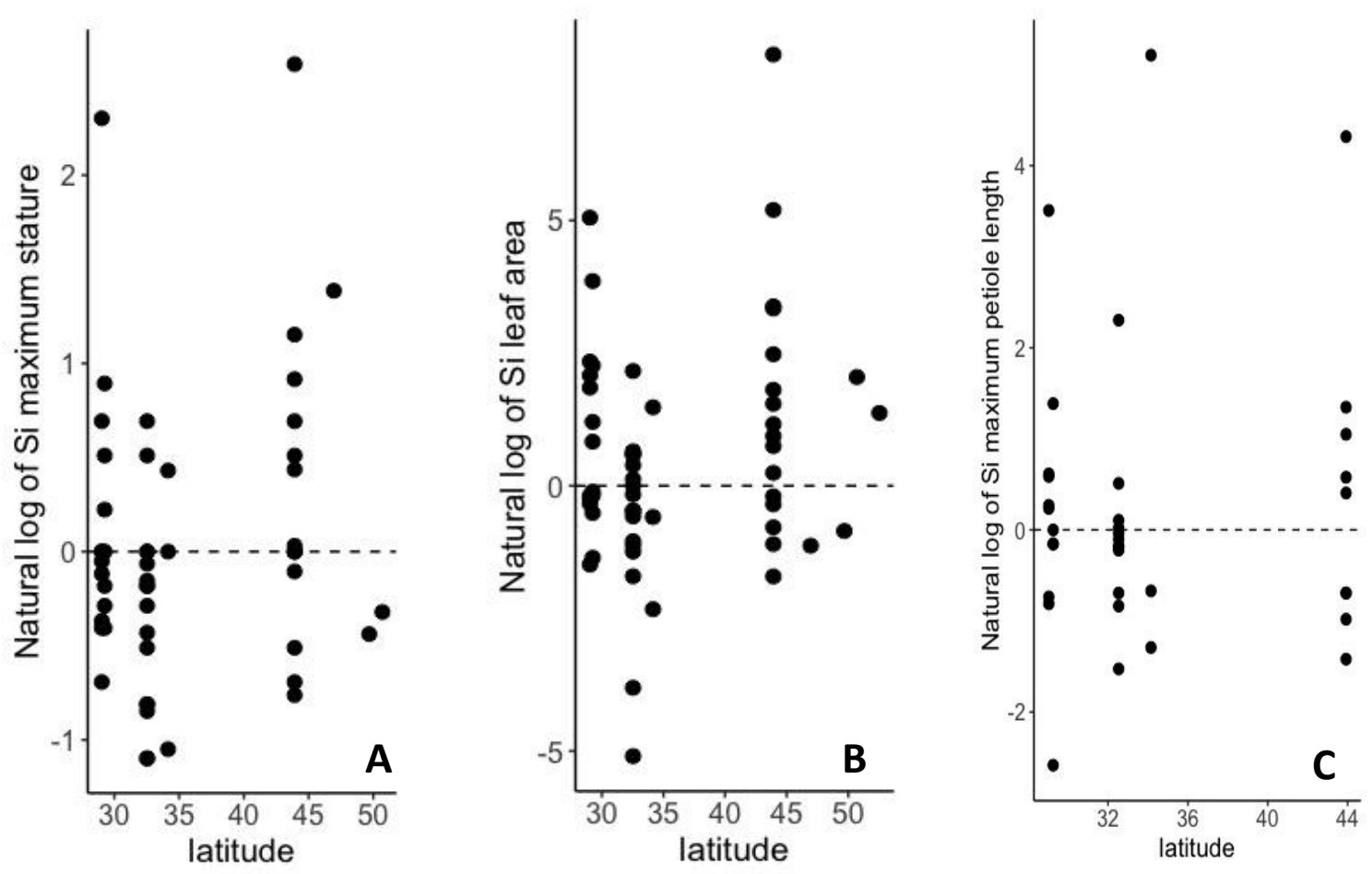

Figure C4 Non-significant graphic results of presence of the Island Rule across latitude for vegetative features: (maximum stature $(A)$, average leaf area (B), and Maximum petiole length $(C)$ ). The dashed lined represented the line of isometry, where Island values = mainland values. See appendices for test statistics values. $Y$ axis is natural logged, amd latitude is measured in 'Decimal degrees'. 


\section{Species composition and measurement type and reference for vegetative features}

Table C6 Maximum stature dataset measurements and measurement references

\begin{tabular}{|c|c|c|c|c|c|c|}
\hline $\begin{array}{l}\text { measurement } \\
\text { type }\end{array}$ & island species & $\begin{array}{l}\text { Stature } \\
\text { max } \\
\text { Island m }\end{array}$ & $\begin{array}{l}\text { Island Stature } \\
\text { reference }\end{array}$ & $\begin{array}{l}\text { Mainland } \\
\text { relative }\end{array}$ & $\begin{array}{l}\text { Stature max } \\
\text { Mainland m }\end{array}$ & $\begin{array}{l}\text { Mainland Stature } \\
\text { reference }\end{array}$ \\
\hline herbarium & $\begin{array}{l}\text { Abrotanella } \\
\text { rosulata }\end{array}$ & 0.01 & SP102466 & $\begin{array}{l}\text { Abrotanella } \\
\text { spathulata }\end{array}$ & 3.66 & K000796675, SP57761 \\
\hline flora & $\begin{array}{l}\text { Alectryon excelsus } \\
\text { grandis }\end{array}$ & 7 & nzflora & $\begin{array}{l}\text { Alectryon } \\
\text { excelsus } \\
\text { excelsus }\end{array}$ & 20 & nzcpn \\
\hline herbarium & Alyxia squamulosa & 2.5 & $\begin{array}{l}\text { Mel223111, } \\
\text { MEL223108 } \\
\text { descriptions }\end{array}$ & $\begin{array}{l}\text { Alyxia } \\
\text { reinwardtii }\end{array}$ & 3 & $\begin{array}{l}\text { H570/97 50, } \\
\text { comfirmed by eflora }\end{array}$ \\
\hline flora & $\begin{array}{l}\text { Araucaria } \\
\text { heterophylla }\end{array}$ & 70 & $\begin{array}{l}\text { Australian } \\
\text { Flora book vol } \\
49\end{array}$ & $\begin{array}{l}\text { Araucaria } \\
\text { cunninghamii }\end{array}$ & 70 & eflora \\
\hline flora & $\begin{array}{l}\text { Asplenium } \\
\text { dimorphum }\end{array}$ & 0.4 & $\begin{array}{l}\text { Australian } \\
\text { Flora book vol } \\
49\end{array}$ & $\begin{array}{l}\text { Asplenium } \\
\text { difforme }\end{array}$ & 0.45 & $\begin{array}{l}\text { Australian Flora book } \\
\text { vol } 49\end{array}$ \\
\hline flora & $\begin{array}{l}\text { Brachyglottis } \\
\text { arborescens }\end{array}$ & 6 & Oliver 1948 & $\begin{array}{l}\text { Brachyglottis } \\
\text { repanda }\end{array}$ & 6 & nzflora \\
\hline flora & $\begin{array}{l}\text { Brachyglottis } \\
\text { huntii }\end{array}$ & 6 & nzflora & $\begin{array}{l}\text { Brachyglottis } \\
\text { stewartiae }\end{array}$ & 6 & nzflora \\
\hline herbarium & Carex chathamica & 0.45 & $\begin{array}{l}\text { AK314668, } \\
\text { confirmed by } \\
\text { nzflora }\end{array}$ & $\begin{array}{l}\text { Carex } \\
\text { kermadecensis }\end{array}$ & 1.1 & AK366570, AK29529 \\
\hline flora & Carex ventosa & 0.6 & nzflora & carex trifida & 1 & nzflora \\
\hline flora & Carmichaelia exsul & 3 & $\begin{array}{l}\text { Australian } \\
\text { Flora book vol } \\
49\end{array}$ & $\begin{array}{l}\text { Carmichaelia } \\
\text { williamsii }\end{array}$ & 4 & Nz flora \\
\hline flora & $\begin{array}{l}\text { Coprosma } \\
\text { acutifolia }\end{array}$ & 10 & nzflora & $\begin{array}{l}\text { Coprosma } \\
\text { propinqua }\end{array}$ & 6 & nzflora \\
\hline flora & Coprosma pilosa & 6 & $\begin{array}{l}\text { Australian } \\
\text { Flora book vol } \\
49\end{array}$ & $\begin{array}{l}\text { Coprosma } \\
\text { fowerakeri }\end{array}$ & 0.6 & nzflora \\
\hline flora & $\begin{array}{l}\text { Coprosma } \\
\text { propinqua var. } \\
\text { martinii }\end{array}$ & 6 & Allan 1982 & $\begin{array}{l}\text { Coprosma } \\
\text { propinqua var. } \\
\text { propinqua }\end{array}$ & 6 & Allan 1982 \\
\hline flora & $\begin{array}{l}\text { Corokia } \\
\text { macrocarpa }\end{array}$ & 6 & nzflora & $\begin{array}{l}\text { Corokia } \\
\text { cotoneaster }\end{array}$ & 3 & nzflora \\
\hline flora & $\begin{array}{l}\text { Cryptocarya } \\
\text { gregsonii }\end{array}$ & 12 & $\begin{array}{l}\text { Australian } \\
\text { Flora book vol } \\
49\end{array}$ & $\begin{array}{l}\text { Cryptocarya } \\
\text { densiflora }\end{array}$ & 20 & eflora \\
\hline flora & Cyathea milnei & 8 & nzflora & $\begin{array}{l}\text { Cyathea } \\
\text { dealbata }\end{array}$ & 12 & nzflora \\
\hline flora & Cyperus insularis & 2 & nzflora & $\begin{array}{l}\text { Cyperus } \\
\text { ustulatus }\end{array}$ & 2 & nzflora \\
\hline flora & $\begin{array}{l}\text { Dendrobium } \\
\text { moorei }\end{array}$ & 0.25 & $\begin{array}{l}\text { Australian } \\
\text { Flora book vol } \\
49\end{array}$ & $\begin{array}{l}\text { Dendrobium } \\
\text { kingianum }\end{array}$ & 0.3 & PlantNET \\
\hline herbarium & Festuca coxii & 0.48 & AK2009 & $\begin{array}{l}\text { Festuca } \\
\text { luciarum }\end{array}$ & 0.47 & AK20090 \\
\hline flora & $\begin{array}{l}\text { Gentianella } \\
\text { antipoda }\end{array}$ & 0.1 & nzflora & $\begin{array}{l}\text { Gentianella } \\
\text { cerina }\end{array}$ & 0.16 & nzflora \\
\hline flora & $\begin{array}{l}\text { Gentianella } \\
\text { chathamica subsp. } \\
\text { Chathamica }\end{array}$ & 0.16 & nzflora & $\begin{array}{l}\text { Gentianella } \\
\text { saxosa }\end{array}$ & 0.11 & nzflora \\
\hline
\end{tabular}




\begin{tabular}{|c|c|c|c|c|c|c|}
\hline flora & $\begin{array}{l}\text { Hedyscepe } \\
\text { canterburyana }\end{array}$ & 15 & $\begin{array}{l}\text { Australian } \\
\text { Flora book vol } \\
49\end{array}$ & $\begin{array}{l}\text { Basselinia } \\
\text { glabrata }\end{array}$ & 15 & palmpedia \\
\hline herbarium & $\begin{array}{l}\text { Korthalsella } \\
\text { disticha }\end{array}$ & 0.19 & $\begin{array}{l}\text { K000912682, } \\
\text { AK23262 }\end{array}$ & $\begin{array}{l}\text { Korthalsella } \\
\text { dichotoma }\end{array}$ & 0.20 & $\begin{array}{l}\text { K000912677, } \\
\text { L3923569, 2927190, } \\
\text { P00078675, } \\
\text { P04697482, } \\
\text { P05066328, } \\
\text { P05097223, } \\
\text { P05066329 }\end{array}$ \\
\hline flora & $\begin{array}{l}\text { Korthalsella } \\
\text { emersa }\end{array}$ & 0.15 & $\begin{array}{l}\text { Australian } \\
\text { Flora book vol } \\
49\end{array}$ & $\begin{array}{l}\text { Korthalsella } \\
\text { rubra }\end{array}$ & 0.16 & vic flora \\
\hline flora & Lepidium oblitum & 0.95 & nzcpn & $\begin{array}{l}\text { Lepidium } \\
\text { obtusatum }\end{array}$ & 0.3 & nzflora \\
\hline flora & $\begin{array}{l}\text { Leptecophylla } \\
\text { robusta }\end{array}$ & 5 & nzflora & $\begin{array}{l}\text { Leptecophylla } \\
\text { juniperina }\end{array}$ & 2 & nzcpn \\
\hline flora & $\begin{array}{l}\text { Leptinella } \\
\text { featherstonii }\end{array}$ & 2 & nzcpn & $\begin{array}{l}\text { Leptinella } \\
\text { serrulata }\end{array}$ & 0.05 & Lloyd 1972 \\
\hline flora & $\begin{array}{l}\text { Melaleuca } \\
\text { howeana }\end{array}$ & 3 & $\begin{array}{l}\text { Australian } \\
\text { Flora book vol } \\
49\end{array}$ & $\begin{array}{l}\text { Melaleuca } \\
\text { ericifolia }\end{array}$ & 7 & vic flora \\
\hline flora & $\begin{array}{l}\text { Melicope } \\
\text { polybotrya }\end{array}$ & 8 & $\begin{array}{l}\text { Australian } \\
\text { Flora book vol } \\
49\end{array}$ & $\begin{array}{l}\text { Sarcomelicope } \\
\text { simplicifolia }\end{array}$ & 12 & PlantNET \\
\hline flora & $\begin{array}{l}\text { Melicytus novae- } \\
\text { zelandia subsp. } \\
\text { centurionis }\end{array}$ & 5 & $\begin{array}{l}\text { Australian } \\
\text { Flora book vol } \\
49\end{array}$ & $\begin{array}{l}\text { Melicytus } \\
\text { novae- } \\
\text { zelandia } \\
\text { subsp. novae- } \\
\text { zelandiae }\end{array}$ & 3 & Allan 1982 \\
\hline flora & Meryta latifolia & 6 & $\begin{array}{l}\text { Australian } \\
\text { Flora book vol } \\
49\end{array}$ & $\begin{array}{l}\text { Meryta } \\
\text { denhamii }\end{array}$ & 3 & rarepalmseeds.com \\
\hline flora & $\begin{array}{l}\text { Metrosideros } \\
\text { kermadecensis }\end{array}$ & 15 & nzflora & $\begin{array}{l}\text { Metrosideros } \\
\text { excelsa }\end{array}$ & 20 & nzflora \\
\hline herbarium & $\begin{array}{l}\text { Myosotidium } \\
\text { hortensia }\end{array}$ & 1 & $\begin{array}{l}\text { K001067060 - } \\
\text { confirmed } \\
\text { with nzcpn } \\
\text { and field } \\
\text { measurements }\end{array}$ & $\begin{array}{l}\text { Cynoglossum } \\
\text { paniculatum }\end{array}$ & 0.6 & $\begin{array}{l}\text { HAL0115079, } \\
\text { K000573727, }\end{array}$ \\
\hline flora & $\begin{array}{l}\text { Myrsine } \\
\text { chathamica }\end{array}$ & 12 & nzcpn & $\begin{array}{l}\text { Myrsine } \\
\text { aquilonia }\end{array}$ & 12 & nzflora \\
\hline flora & $\begin{array}{l}\text { Myrsine } \\
\text { platystigma }\end{array}$ & 6 & $\begin{array}{l}\text { Australian } \\
\text { Flora book vol } \\
49\end{array}$ & Myrsine faberi & 6 & flora of china \\
\hline flora & $\begin{array}{l}\text { Negria } \\
\text { rhabdothamnoidea }\end{array}$ & 8 & $\begin{array}{l}\text { Australian } \\
\text { Flora book vol } \\
49\end{array}$ & $\begin{array}{l}\text { Lenbrassia } \\
\text { australiana }\end{array}$ & 4 & $\begin{array}{l}\text { australian tropical } \\
\text { rainforest plants }\end{array}$ \\
\hline flora & Olearia mooneyi & 4 & $\begin{array}{l}\text { Australian } \\
\text { Flora book vol } \\
49\end{array}$ & $\begin{array}{l}\text { Olearia } \\
\text { argophylla }\end{array}$ & 9 & plantnet \\
\hline flora & Pandanus forsteri & 13 & $\begin{array}{l}\text { Australian } \\
\text { Flora book vol } \\
49\end{array}$ & $\begin{array}{l}\text { Pandanus } \\
\text { kanehirae }\end{array}$ & 20 & botany \\
\hline flora & $\begin{array}{l}\text { Pennantia } \\
\text { endlicheri }\end{array}$ & 10 & $\begin{array}{l}\text { Australian } \\
\text { Flora book vol } \\
49\end{array}$ & $\begin{array}{l}\text { Pennantia } \\
\text { corymbosa }\end{array}$ & 10 & nzflora \\
\hline flora & $\begin{array}{l}\text { Pittosporum } \\
\text { bracteolatum }\end{array}$ & 8 & $\begin{array}{l}\text { Australian } \\
\text { Flora book vol } \\
49\end{array}$ & $\begin{array}{l}\text { Pittosporum } \\
\text { umbellatum }\end{array}$ & 12 & nzcpn \\
\hline herbarium & $\begin{array}{l}\text { Plantago } \\
\text { aucklandica }\end{array}$ & 0.11 & K000438784 & $\begin{array}{l}\text { Plantago } \\
\text { lanigera }\end{array}$ & 0.15 & SP104833/A SP089135 \\
\hline
\end{tabular}




\begin{tabular}{|c|c|c|c|c|c|c|}
\hline flora & Plectorrhiza erecta & 0.3 & $\begin{array}{l}\text { Australian } \\
\text { Flora book vol } \\
49\end{array}$ & $\begin{array}{l}\text { Plectorrhiza } \\
\text { tridentata }\end{array}$ & 0.35 & plantNet \\
\hline flora & Poa chathamica & 0.9 & nzflora & Poa cita & 1 & nzflora \\
\hline flora & $\begin{array}{l}\text { Pseudopanax } \\
\text { chathamicus }\end{array}$ & 7 & nzflora & $\begin{array}{l}\text { Pseudopanax } \\
\text { crassifolius }\end{array}$ & 15 & nzflora \\
\hline flora & $\begin{array}{l}\text { Pseudopanax } \\
\text { kermadecensis }\end{array}$ & 10 & nzflora & $\begin{array}{l}\text { Pseudopanax } \\
\text { arboreus }\end{array}$ & 8 & nzflora \\
\hline flora & Pteris kingiana & 0.9 & $\begin{array}{l}\text { Australian } \\
\text { Flora book vol } \\
49\end{array}$ & Pteris tremula & 1.3 & vicflora \\
\hline flora & Raoulia goyenii & 0.2 & nzflora & $\begin{array}{l}\text { Raoulia } \\
\text { buchananii }\end{array}$ & 0.05 & nzflora \\
\hline flora & Senecio australis & 1 & nzflora & $\begin{array}{l}\text { Senecio } \\
\text { minimus }\end{array}$ & 2 & nzcpn \\
\hline herbaruim & $\begin{array}{l}\text { Sonchus } \\
\text { grandifolius }\end{array}$ & 2 & $\begin{array}{l}\text { K000808042, } \\
\text { confirmed by } \\
\text { nzflora }\end{array}$ & $\begin{array}{l}\text { Sonchus } \\
\text { novae- } \\
\text { zelandiae }\end{array}$ & 0.15 & K000323043 \\
\hline flora & Sonchus kirkii & 1 & nzflora & $\begin{array}{l}\text { Sonchus } \\
\text { oleraceus }\end{array}$ & 1.2 & nzflora \\
\hline flora & $\begin{array}{l}\text { Sporadanthus } \\
\text { traversii }\end{array}$ & 2.5 & nzflora & $\begin{array}{l}\text { Sporadanthus } \\
\text { ferrugineus }\end{array}$ & 5 & nzflora \\
\hline herbarium & Veronica insularis & 1 & $\begin{array}{l}\text { AK217304, } \\
\text { AK183138 } \\
\text { confirmed by } \\
\text { nzflora }\end{array}$ & $\begin{array}{l}\text { Veronica } \\
\text { orchidea }\end{array}$ & 0.65 & 102778,102776 \\
\hline herbarium & $\begin{array}{l}\text { Xylosma } \\
\text { parviflorum }\end{array}$ & 2 & $\begin{array}{l}\text { MEL582309 } \\
\text { MEL100642 } \\
\text { MEL582308, } \\
\text { confirmed by } \\
\text { aussie flora } \\
\text { book }\end{array}$ & $\begin{array}{l}\text { Xylosma } \\
\text { vincentii }\end{array}$ & 6 & P00648883 \\
\hline
\end{tabular}

Table C7 Leaf area dataset measurements and measurement references

\begin{tabular}{|c|c|c|c|c|c|c|}
\hline $\begin{array}{l}\text { measurement } \\
\text { type }\end{array}$ & island species & $\begin{array}{l}\text { Island } \\
\text { average leaf } \\
\text { area }\left(\mathrm{cm}^{2}\right)\end{array}$ & $\begin{array}{l}\text { Island leaf } \\
\text { measurement } \\
\text { reference(s) }\end{array}$ & $\begin{array}{l}\text { Mainland } \\
\text { relative }\end{array}$ & $\begin{array}{l}\text { Mainland } \\
\text { average leaf } \\
\text { area }\left(\mathrm{cm}^{2}\right)\end{array}$ & $\begin{array}{l}\text { Mainland leaf } \\
\text { measurement } \\
\text { reference(s) }\end{array}$ \\
\hline herbarium & $\begin{array}{l}\text { Abrotanella } \\
\text { rosulata }\end{array}$ & 0.24 & SP102466 & $\begin{array}{l}\text { Abrotanella } \\
\text { spathulata }\end{array}$ & 0.7 & $\begin{array}{l}\text { K000796675, } \\
\text { SP57761 }\end{array}$ \\
\hline flora & $\begin{array}{l}\text { Alectryon excelsus } \\
\text { grandis }\end{array}$ & 97.09 & nzflora & $\begin{array}{l}\text { Alectryon } \\
\text { excelsus } \\
\text { excelsus }\end{array}$ & 22.12 & nzcpn \\
\hline flora & Alyxia squamulosa & 11.89 & $\begin{array}{l}\text { Australian Flora } \\
\text { book, vol } 49\end{array}$ & $\begin{array}{l}\text { Alyxia } \\
\text { reinwardtii }\end{array}$ & 19 & eflora \\
\hline flora & $\begin{array}{l}\text { Araucaria } \\
\text { heterophylla }\end{array}$ & 0.25 & $\begin{array}{l}\text { Australian Flora } \\
\text { book, vol } 49\end{array}$ & $\begin{array}{l}\text { Araucaria } \\
\text { cunninghamii }\end{array}$ & 0.3 & eflora \\
\hline flora & $\begin{array}{l}\text { Asplenium } \\
\text { dimorphum }\end{array}$ & 1462.5 & $\begin{array}{l}\text { Australian Flora } \\
\text { book, vol } 49\end{array}$ & $\begin{array}{l}\text { Asplenium } \\
\text { difforme }\end{array}$ & 182.48 & $\begin{array}{l}\text { Australian Flora } \\
\text { book, vol } 49\end{array}$ \\
\hline flora & Blechnum fullagari & 440 & $\begin{array}{l}\text { Australian Flora } \\
\text { book, vol } 49\end{array}$ & $\begin{array}{l}\text { Blechnum } \\
\text { nigrum }\end{array}$ & 50.63 & nzflora \\
\hline flora & $\begin{array}{l}\text { Blechnum } \\
\text { howeanum }\end{array}$ & 2800 & $\begin{array}{l}\text { Australian Flora } \\
\text { book, vol } 49\end{array}$ & $\begin{array}{l}\text { Blechnum } \\
\text { triangularifolium }\end{array}$ & 3300 & nzcpn \\
\hline herbarium & $\begin{array}{l}\text { Brachyglottis } \\
\text { arborescens }\end{array}$ & 104 & Oliver, 1948 & $\begin{array}{l}\text { Brachyglottis } \\
\text { repanda }\end{array}$ & 187.5 & $\begin{array}{l}\text { M0030359, } \\
\text { BM000810473, } \\
\text { CHR 216104 C, } \\
\text { CHR } 216104 \text { B }\end{array}$ \\
\hline flora & $\begin{array}{l}\text { Brachyglottis } \\
\text { huntii }\end{array}$ & 12.5 & nzflora & $\begin{array}{l}\text { Brachyglottis } \\
\text { stewartiae }\end{array}$ & 37.5 & nzflora \\
\hline herbarium & Carex chathamica & 21.76 & AK314668 & $\begin{array}{l}\text { Carex } \\
\text { kermadecensis }\end{array}$ & 78.86 & $\begin{array}{l}\text { AK366570, } \\
\text { AK29529 }\end{array}$ \\
\hline
\end{tabular}


Appendices-Appendix C

\begin{tabular}{|c|c|c|c|c|c|c|}
\hline hebarium & Carex ventosa & 36 & herbarium & carex trifida & 78.75 & herbarium \\
\hline flora & Carmichaelia exsul & 2.77 & $\begin{array}{l}\text { Australian Flora } \\
\text { book, vol } 49\end{array}$ & $\begin{array}{l}\text { Carmichaelia } \\
\text { williamsii }\end{array}$ & 1.45 & nzflora \\
\hline flora & $\begin{array}{l}\text { Coprosma } \\
\text { acutifolia }\end{array}$ & 18.56 & nzflora & $\begin{array}{l}\text { Coprosma } \\
\text { propinqua }\end{array}$ & 0.39 & nzflora \\
\hline flora & Coprosma pilosa & 1.39 & $\begin{array}{l}\text { Australian Flora } \\
\text { book, vol } 49\end{array}$ & $\begin{array}{l}\text { Coprosma } \\
\text { fowerakeri }\end{array}$ & 0.22 & nzflora \\
\hline flora & $\begin{array}{l}\text { Coprosma } \\
\text { propinqua var. } \\
\text { martinii }\end{array}$ & 0.61 & nzflora & $\begin{array}{l}\text { Coprosma } \\
\text { propinqua var. } \\
\text { propinqua }\end{array}$ & 0.19 & nzflora \\
\hline flora & $\begin{array}{l}\text { Corokia } \\
\text { macrocarpa }\end{array}$ & 15 & nzflora & $\begin{array}{l}\text { Corokia } \\
\text { cotoneaster }\end{array}$ & 0.51 & nzflora \\
\hline herbarium & $\begin{array}{l}\text { Cryptocarya } \\
\text { gregsonii }\end{array}$ & 24.41 & $\begin{array}{l}\text { NSW524068, } \\
\text { NSW524032 }\end{array}$ & $\begin{array}{l}\text { Cryptocarya } \\
\text { densiflora }\end{array}$ & 84.38 & $\begin{array}{l}\text { L0036112, } \\
\text { GH00041368 }\end{array}$ \\
\hline flora & Cyathea milnei & 19000 & nzflora & $\begin{array}{l}\text { Cyathea } \\
\text { dealbata }\end{array}$ & 21218.75 & nzflora \\
\hline flora & Cyperus insularis & 345 & nzflora & $\begin{array}{l}\text { Cyperus } \\
\text { ustulatus }\end{array}$ & 103.5 & nzcpn \\
\hline flora & $\begin{array}{l}\text { Dendrobium } \\
\text { moorei }\end{array}$ & 17.5 & $\begin{array}{l}\text { Australian Flora } \\
\text { book, vol } 49\end{array}$ & $\begin{array}{l}\text { Dendrobium } \\
\text { kingianum }\end{array}$ & 9.75 & plantnet \\
\hline flora & Festuca coxii & 1.69 & nzflora & $\begin{array}{l}\text { Festuca } \\
\text { luciarum }\end{array}$ & 0.06 & nzflora \\
\hline flora & $\begin{array}{l}\text { Gentianella } \\
\text { antipoda }\end{array}$ & 2.01 & nzflora & $\begin{array}{l}\text { Gentianella } \\
\text { cerina }\end{array}$ & 4.71 & nzflora \\
\hline flora & $\begin{array}{l}\text { Gentianella } \\
\text { chathamica subsp. } \\
\text { Chathamica }\end{array}$ & 4.45 & nzflora & $\begin{array}{l}\text { Gentianella } \\
\text { saxosa }\end{array}$ & 5.42 & nzflora \\
\hline flora & $\begin{array}{l}\text { Hypolepis } \\
\text { dicksonioides }\end{array}$ & 1793.84 & nzcpn & $\begin{array}{l}\text { Hypolepis } \\
\text { rugosula }\end{array}$ & 3000 & $\begin{array}{l}\text { Brownsey \& } \\
\text { Chinnock } 1987\end{array}$ \\
\hline herbarium & $\begin{array}{l}\text { Korthalsella } \\
\text { disticha }\end{array}$ & 5.4 & $\begin{array}{l}\text { K000912682, } \\
\text { AK23262 }\end{array}$ & $\begin{array}{l}\text { Korthalsella } \\
\text { dichotoma }\end{array}$ & 8 & $\begin{array}{l}\text { K000912677, } \\
\text { L3923569, } \\
2927190, \\
\text { P00078675, } \\
\text { P04697482, } \\
\text { P05066328, } \\
\text { P05097223, } \\
\text { P05066329 }\end{array}$ \\
\hline flora & $\begin{array}{l}\text { Korthalsella } \\
\text { emersa }\end{array}$ & 1.39 & $\begin{array}{l}\text { Australian Flora } \\
\text { book, vol } 49\end{array}$ & $\begin{array}{l}\text { Korthalsella } \\
\text { rubra }\end{array}$ & 0.77 & vicflora \\
\hline flora & Lepidium oblitum & 13.2 & nzcpn & $\begin{array}{l}\text { Lepidium } \\
\text { obtusatum }\end{array}$ & 6.25 & nzcpn \\
\hline flora & $\begin{array}{l}\text { Leptecophylla } \\
\text { robusta }\end{array}$ & 0.8 & nzflora & $\begin{array}{l}\text { Leptecophylla } \\
\text { juniperina }\end{array}$ & 0.17 & nzcpn \\
\hline flora & $\begin{array}{l}\text { Leptinella } \\
\text { featherstonii }\end{array}$ & 3.3 & nzflora & $\begin{array}{l}\text { Leptinella } \\
\text { serrulata }\end{array}$ & 0.54 & nzflora \\
\hline flora & $\begin{array}{l}\text { Melaleuca } \\
\text { howeana }\end{array}$ & 0.08 & $\begin{array}{l}\text { Australian Flora } \\
\text { book, vol } 49\end{array}$ & $\begin{array}{l}\text { Melaleuca } \\
\text { ericifolia }\end{array}$ & 0.13 & vicflora \\
\hline flora & $\begin{array}{l}\text { Melicope } \\
\text { polybotrya }\end{array}$ & 51.02 & $\begin{array}{l}\text { Australian Flora } \\
\text { book, vol } 49\end{array}$ & $\begin{array}{l}\text { Sarcomelicope } \\
\text { simplicifolia }\end{array}$ & 45 & plantnet \\
\hline flora & $\begin{array}{l}\text { Melicytus novae- } \\
\text { zelandia subsp. } \\
\text { centurionis }\end{array}$ & 21 & $\begin{array}{l}\text { Australian Flora } \\
\text { book, vol } 49\end{array}$ & $\begin{array}{l}\text { Melicytus } \\
\text { novae-zelandia } \\
\text { subsp. novae- } \\
\text { zelandiae }\end{array}$ & 21 & nzcpn \\
\hline flora & Meryta latifolia & 1718.75 & $\begin{array}{l}\text { Australian Flora } \\
\text { book, vol } 49\end{array}$ & $\begin{array}{l}\text { Meryta } \\
\text { denhamii }\end{array}$ & 2400 & $\begin{array}{l}\text { Exploring the } \\
\text { world of trees }\end{array}$ \\
\hline flora & $\begin{array}{l}\text { Metrosideros } \\
\text { kermadecensis }\end{array}$ & 5.25 & nzflora & $\begin{array}{l}\text { Metrosideros } \\
\text { excelsa }\end{array}$ & 20.41 & nzflora \\
\hline herbarium & $\begin{array}{l}\text { Myosotidium } \\
\text { hortensia }\end{array}$ & 799.19 & $\begin{array}{l}\text { K001067060 - } \\
\text { confirmed with } \\
\text { nzcpn and field } \\
\text { measurements }\end{array}$ & $\begin{array}{l}\text { Cynoglossum } \\
\text { paniculatum }\end{array}$ & 4.41 & K000573727 \\
\hline
\end{tabular}


Appendices - Appendix C

\begin{tabular}{|c|c|c|c|c|c|c|}
\hline flora & $\begin{array}{l}\text { Myrsine } \\
\text { chathamica }\end{array}$ & 32.22 & nzcpn & $\begin{array}{l}\text { Myrsine } \\
\text { aquilonia }\end{array}$ & 2.7 & nzflora \\
\hline herbarium & $\begin{array}{l}\text { Myrsine } \\
\text { platystigma }\end{array}$ & 6 & $\begin{array}{l}\text { MEL622061, } \\
\text { K000756398, } \\
\text { BR0000005225002 }\end{array}$ & Myrsine faberi & 33 & A00062246 \\
\hline flora & $\begin{array}{l}\text { Negria } \\
\text { rhabdothamnoidea }\end{array}$ & 97.87 & $\begin{array}{l}\text { Australian Flora } \\
\text { book, vol } 49\end{array}$ & $\begin{array}{l}\text { Lenbrassia } \\
\text { australiana }\end{array}$ & 66.5 & $\begin{array}{l}\text { Australian } \\
\text { tropical } \\
\text { Rainforest Plants }\end{array}$ \\
\hline flora & Olearia mooneyi & 17.5 & $\begin{array}{l}\text { Australian Flora } \\
\text { book, vol } 49\end{array}$ & $\begin{array}{l}\text { Olearia } \\
\text { argophylla }\end{array}$ & 49.75 & plantnet \\
\hline flora & Pandanus forsteri & 500 & $\begin{array}{l}\text { Australian Flora } \\
\text { book, vol } 49\end{array}$ & $\begin{array}{l}\text { Pandanus } \\
\text { kanehirae }\end{array}$ & 1550 & botany.cz \\
\hline flora & $\begin{array}{l}\text { Pennantia } \\
\text { endlicheri }\end{array}$ & 129.06 & $\begin{array}{l}\text { Australian Flora } \\
\text { book, vol } 49\end{array}$ & $\begin{array}{l}\text { Pennantia } \\
\text { corymbosa }\end{array}$ & 0.82 & nzflora \\
\hline flora & $\begin{array}{l}\text { Pittosporum } \\
\text { bracteolatum }\end{array}$ & 21.18 & $\begin{array}{l}\text { Australian Flora } \\
\text { book, vol } 49\end{array}$ & $\begin{array}{l}\text { Pittosporum } \\
\text { umbellatum }\end{array}$ & 26.25 & nzflora \\
\hline flora & $\begin{array}{l}\text { Plantago } \\
\text { aucklandica }\end{array}$ & 26.56 & nzflora & $\begin{array}{l}\text { Plantago } \\
\text { lanigera }\end{array}$ & 3.42 & nzflora \\
\hline flora & Plectorrhiza erecta & 3.38 & $\begin{array}{l}\text { Australian Flora } \\
\text { book, vol } 49\end{array}$ & $\begin{array}{l}\text { Plectorrhiza } \\
\text { tridentata }\end{array}$ & 6.01 & plantnet \\
\hline flora & Poa chathamica & 6.13 & nzflora & Poa cita & 4.8 & nzflora \\
\hline flora & $\begin{array}{l}\text { Pseudopanax } \\
\text { chathamicus }\end{array}$ & 95.63 & nzflora & $\begin{array}{l}\text { Pseudopanax } \\
\text { crassifolius }\end{array}$ & 37.5 & nzflora \\
\hline flora & $\begin{array}{l}\text { Pseudopanax } \\
\text { kermadecensis }\end{array}$ & 68.75 & nzcpn & $\begin{array}{l}\text { Pseudopanax } \\
\text { arboreus }\end{array}$ & 82.5 & nzcpn \\
\hline flora & Pteris kingiana & 763.75 & $\begin{array}{l}\text { Australian Flora } \\
\text { book, vol } 49\end{array}$ & Pteris tremula & 3375 & nzcpn \\
\hline flora & Pteris microptera & 22.5 & $\begin{array}{l}\text { Australian Flora } \\
\text { book, vol } 49\end{array}$ & Pteris comans & 3675 & nzflora \\
\hline flora & Raoulia goyenii & 0.03 & nzflora & $\begin{array}{l}\text { Raoulia } \\
\text { buchananii }\end{array}$ & 0.08 & nzflora \\
\hline herbarium & Senecio australis & 17.87 & $\begin{array}{l}\text { K000250508, } \\
\text { G00468809, } \\
\text { G00468791 }\end{array}$ & Senecio minimus & 23.2 & $\begin{array}{l}\text { K000852323 } \\
\text { K000852325 }\end{array}$ \\
\hline flora & $\begin{array}{l}\text { Senecio } \\
\text { kermadecensis }\end{array}$ & 15 & nzflora & Senecio hauwai & 1.56 & nzflora \\
\hline flora & $\begin{array}{l}\text { Sonchus } \\
\text { grandifolius }\end{array}$ & 1600 & nzflora & $\begin{array}{l}\text { Sonchus novae- } \\
\text { zelandiae }\end{array}$ & 0.47 & Allan 1982 \\
\hline flora & Sonchus kirkii & 134.38 & nzflora & $\begin{array}{l}\text { Sonchus } \\
\text { oleraceus }\end{array}$ & 58.53 & nzflora \\
\hline flora & $\begin{array}{l}\text { Sporadanthus } \\
\text { traversii }\end{array}$ & 1.91 & nzflora & $\begin{array}{l}\text { Sporadanthus } \\
\text { ferrugineus }\end{array}$ & 10.56 & nzflora \\
\hline herbarium & Veronica insularis & 2.5 & $\begin{array}{l}\text { Royal Botanic } \\
\text { Gardens, Kew (K), } \\
\text { K001070461 }\end{array}$ & $\begin{array}{l}\text { Veronica } \\
\text { orchidea }\end{array}$ & 25.6 & $\begin{array}{l}\text { 3308, } \\
\text { P03516880, } \\
\text { P02502869, }\end{array}$ \\
\hline herbarium & $\begin{array}{l}\text { Xylosma } \\
\text { parvifolium }\end{array}$ & 1.38 & $\begin{array}{l}\text { MEL582309, } \\
\text { MEL100642, } \\
\text { MEL582308 }\end{array}$ & $\begin{array}{l}\text { Xylosma } \\
\text { vincentii }\end{array}$ & 62 & L0011394 \\
\hline
\end{tabular}

Table C8 Petiole length dataset measurements and measurement references

\begin{tabular}{|c|c|c|c|c|c|c|}
\hline $\begin{array}{l}\text { measurement } \\
\text { type }\end{array}$ & island species & $\begin{array}{l}\text { Petiole } \\
\text { length } \\
\text { island } \mathrm{cm}\end{array}$ & $\begin{array}{l}\text { Island Petiole } \\
\text { reference }\end{array}$ & $\begin{array}{l}\text { Mainland } \\
\text { relative }\end{array}$ & $\begin{array}{l}\text { Petiole } \\
\text { length } \\
\text { mainland } \mathrm{cm}\end{array}$ & $\begin{array}{l}\text { Mainland } \\
\text { Petiole } \\
\text { reference }\end{array}$ \\
\hline herbarium & $\begin{array}{l}\text { Alectryon } \\
\text { excelsus } \\
\text { grandis }\end{array}$ & 5.5 & $\begin{array}{l}\text { AK5125, } \\
\text { AK210756 }\end{array}$ & $\begin{array}{l}\text { Alectryon } \\
\text { excelsus } \\
\text { excelsus }\end{array}$ & 0.03 & AK105236 \\
\hline flora & $\begin{array}{l}\text { Alyxia } \\
\text { squamulosa }\end{array}$ & 0.4 & $\begin{array}{l}\text { Australian } \\
\text { flora book } \\
\text { vol } 49\end{array}$ & $\begin{array}{l}\text { Alyxia } \\
\text { reinwardtii }\end{array}$ & 0.5 & EFLORA \\
\hline
\end{tabular}




\begin{tabular}{|c|c|c|c|c|c|c|}
\hline flora & $\begin{array}{l}\text { Blechnum } \\
\text { fullagari }\end{array}$ & 7.5 & $\begin{array}{l}\text { Australian } \\
\text { flora book } \\
\text { vol } 49\end{array}$ & $\begin{array}{l}\text { Blechnum } \\
\text { nigrum }\end{array}$ & 4.5 & NZFLORA \\
\hline flora & $\begin{array}{l}\text { Blechnum } \\
\text { howeanum }\end{array}$ & 45 & $\begin{array}{l}\text { Australian } \\
\text { flora book } \\
\text { vol } 50\end{array}$ & $\begin{array}{l}\text { Blechnum } \\
\text { triangularifolium }\end{array}$ & 44 & NZCPN \\
\hline herbarium & $\begin{array}{l}\text { Brachyglottis } \\
\text { arborescens }\end{array}$ & 3 & Oliver 1948 & $\begin{array}{l}\text { Brachyglottis } \\
\text { repanda }\end{array}$ & 5.86 & SP58743 \\
\hline herbarium & $\begin{array}{l}\text { Carmichaelia } \\
\text { exsul }\end{array}$ & 0.9 & $\begin{array}{l}\text { K000950835, } \\
\text { MEL2120317 }\end{array}$ & $\begin{array}{l}\text { Carmichaelia } \\
\text { williamsii }\end{array}$ & 1 & K000950929 \\
\hline flora & $\begin{array}{l}\text { Coprosma } \\
\text { acutifolia }\end{array}$ & 0.6 & NZFLORA & $\begin{array}{l}\text { Coprosma } \\
\text { propinqua }\end{array}$ & 0.15 & NZFLORA \\
\hline herbarium & $\begin{array}{l}\text { Coprosma } \\
\text { pilosa }\end{array}$ & 2 & $\begin{array}{l}\text { Australian } \\
\text { flora book } \\
\text { vol } 50\end{array}$ & $\begin{array}{l}\text { Coprosma } \\
\text { fowerakeri }\end{array}$ & 0.06 & NZFLORA \\
\hline flora & $\begin{array}{l}\text { Corokia } \\
\text { macrocarpa }\end{array}$ & 1 & Allan 1982 & $\begin{array}{l}\text { Corokia } \\
\text { cotoneaster }\end{array}$ & 2 & Allan 1982 \\
\hline flora & $\begin{array}{l}\text { Cryptocarya } \\
\text { gregsonii }\end{array}$ & 1.25 & PLANTNET & $\begin{array}{l}\text { Cryptocarya } \\
\text { densiflora }\end{array}$ & 1.5 & EFLORA \\
\hline flora & $\begin{array}{l}\text { Cyathea } \\
\text { brownii }\end{array}$ & 40 & $\begin{array}{l}\text { Australian } \\
\text { flora book } \\
\text { vol } 49\end{array}$ & $\begin{array}{l}\text { Cyathea } \\
\text { robinsonii }\end{array}$ & 90 & $\begin{array}{l}\text { K000754054 } \\
\text { description }\end{array}$ \\
\hline flora & $\begin{array}{l}\text { Gentianella } \\
\text { chathamica } \\
\text { subsp. } \\
\text { Chathamica }\end{array}$ & 0.95 & NZFLORA & $\begin{array}{l}\text { Gentianella } \\
\text { saxosa }\end{array}$ & 3.925 & NZFLORA \\
\hline flora & $\begin{array}{l}\text { Hypolepis } \\
\text { dicksonioides }\end{array}$ & 45 & NZCPN & $\begin{array}{l}\text { Hypolepis } \\
\text { rugosula }\end{array}$ & 52.5 & $\begin{array}{l}\text { Brownsey \& } \\
\text { Chinnock } \\
1987\end{array}$ \\
\hline flora & $\begin{array}{l}\text { Lepidium } \\
\text { oblitum }\end{array}$ & 4 & NZCPN & $\begin{array}{l}\text { Lepidium } \\
\text { obtusatum }\end{array}$ & 8 & NZCPN \\
\hline flora & $\begin{array}{l}\text { Leptecophylla } \\
\text { robusta }\end{array}$ & 0.205 & NZCPN & $\begin{array}{l}\text { Leptecophylla } \\
\text { juniperina }\end{array}$ & 0.115 & NZCPN \\
\hline herbarium & $\begin{array}{l}\text { Melaleuca } \\
\text { howeana }\end{array}$ & 0.05 & NSW365338 & $\begin{array}{l}\text { Melaleuca } \\
\text { ericifolia }\end{array}$ & 0.1 & $\begin{array}{l}\text { LINN- } \\
\text { HS1243-13, } \\
\text { B -W 14365- } \\
010 \text { B -W } \\
14365-020\end{array}$ \\
\hline herbarium & $\begin{array}{l}\text { Melicope } \\
\text { polybotrya }\end{array}$ & 1.3 & K000717407 & $\begin{array}{l}\text { Sarcomelicope } \\
\text { simplicifolia }\end{array}$ & 3 & $\begin{array}{l}\text { P00543913, } \\
\text { P00543914 }\end{array}$ \\
\hline herbarium & $\begin{array}{l}\text { Melicytus } \\
\text { novae- } \\
\text { zelandiae } \\
\text { subsp. } \\
\text { centurionis }\end{array}$ & 1.25 & K000370077 & $\begin{array}{l}\text { Melicytus } \\
\text { novae-zelandia } \\
\text { subsp. novae- } \\
\text { zelandiae }\end{array}$ & 1.3 & AK369727 \\
\hline herbarium & $\begin{array}{l}\text { Metrosideros } \\
\text { kermadecensis }\end{array}$ & 0.5 & $\begin{array}{l}\text { SP095393, } \\
\text { SP088606 }\end{array}$ & $\begin{array}{l}\text { Metrosideros } \\
\text { excelsa }\end{array}$ & 6.62 & SP023044 \\
\hline herbarium & $\begin{array}{l}\text { Myosotidium } \\
\text { hortensia }\end{array}$ & 30 & $\begin{array}{l}\text { 00947912, } \\
\text { confirmed } \\
\text { with NZCPN }\end{array}$ & $\begin{array}{l}\text { Cynoglossum } \\
\text { paniculatum }\end{array}$ & 0.4 & $\begin{array}{l}\text { K000573727 } \\
\text { HAL0115079 }\end{array}$ \\
\hline flora & $\begin{array}{l}\text { Myrsine } \\
\text { chathamica }\end{array}$ & 0.75 & NZCPN & $\begin{array}{l}\text { Myrsine } \\
\text { aquilonia }\end{array}$ & 0.195 & NZFLORA \\
\hline flora & $\begin{array}{l}\text { Olearia } \\
\text { mooneyi }\end{array}$ & 0.75 & $\begin{array}{l}\text { Australian } \\
\text { flora book } \\
\text { vol } 49\end{array}$ & $\begin{array}{l}\text { Olearia } \\
\text { argophylla }\end{array}$ & 0.9 & PLANTNET \\
\hline
\end{tabular}


Appendices-Appendix C

\begin{tabular}{|c|c|c|c|c|c|c|}
\hline flora & $\begin{array}{l}\text { Pennantia } \\
\text { endlicheri }\end{array}$ & 1.85 & $\begin{array}{l}\text { Australian } \\
\text { flora book } \\
\text { vol } 50\end{array}$ & $\begin{array}{l}\text { Pennantia } \\
\text { corymbosa }\end{array}$ & 1 & Allan 1982 \\
\hline herbarium & $\begin{array}{l}\text { Pittosporum } \\
\text { bracteolatum }\end{array}$ & 2.62 & SP084276 & $\begin{array}{l}\text { Pittosporum } \\
\text { umbellatum }\end{array}$ & 2 & $\begin{array}{l}\text { AK102344, } \\
\text { K000591694 }\end{array}$ \\
\hline herbarium & $\begin{array}{l}\text { Plectorrhiza } \\
\text { erecta }\end{array}$ & 1 & Dockrill 1967 & $\begin{array}{l}\text { Plectorrhiza } \\
\text { tridentata }\end{array}$ & 0.1 & MEL1540868 \\
\hline flora & $\begin{array}{l}\text { Pseudopanax } \\
\text { chathamicus }\end{array}$ & 0.15 & Allan 1982 & $\begin{array}{l}\text { Pseudopanax } \\
\text { crassifolius }\end{array}$ & 0.1 & NZCPN \\
\hline flora & $\begin{array}{l}\text { Pseudopanax } \\
\text { kermadecensis }\end{array}$ & 15 & NZCPN & $\begin{array}{l}\text { Pseudopanax } \\
\text { arboreus }\end{array}$ & 17.5 & NZCPN \\
\hline flora & Pteris kingiana & 40 & $\begin{array}{l}\text { Australian } \\
\text { flora book } \\
\text { vol } 50\end{array}$ & Pteris tremula & 31.6 & NZFLORA \\
\hline herbarium & $\begin{array}{l}\text { Senecio } \\
\text { australis }\end{array}$ & 1 & K000250508 & Senecio minimus & 0.556 & K000852325 \\
\hline flora & $\begin{array}{l}\text { Sonchus } \\
\text { grandifolius }\end{array}$ & 20 & NZFLORA & $\begin{array}{l}\text { Sonchus novae- } \\
\text { zelandiae }\end{array}$ & 7 & NZFLORA \\
\hline herbarium & Sonchus kirkii & 0.01 & NSW135787 & $\begin{array}{l}\text { Sonchus } \\
\text { oleraceus }\end{array}$ & 0.01 & K001118922 \\
\hline herbarium & $\begin{array}{l}\text { Xylosma } \\
\text { parvifolium }\end{array}$ & 0.25 & $\begin{array}{l}\text { MEL582309, } \\
\text { MEL100642, } \\
\text { MEL582308 }\end{array}$ & $\begin{array}{l}\text { Xylosma } \\
\text { vincentii }\end{array}$ & 1.15 & L0011394 \\
\hline
\end{tabular}


